Historic, Archive Document

Do not assume content reflects current scientific knowledge, policies, or practices. 

[Twenty First Annual Catalog 1930

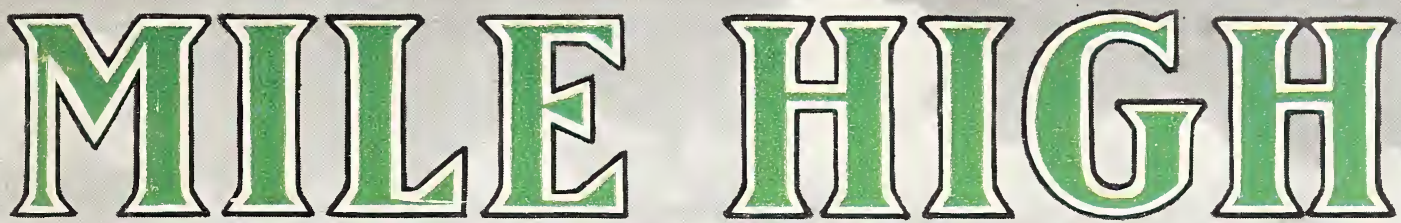

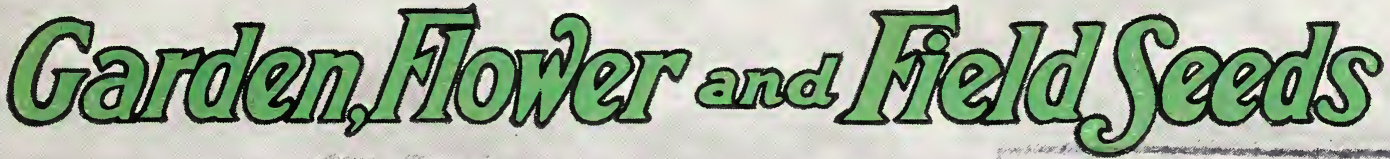
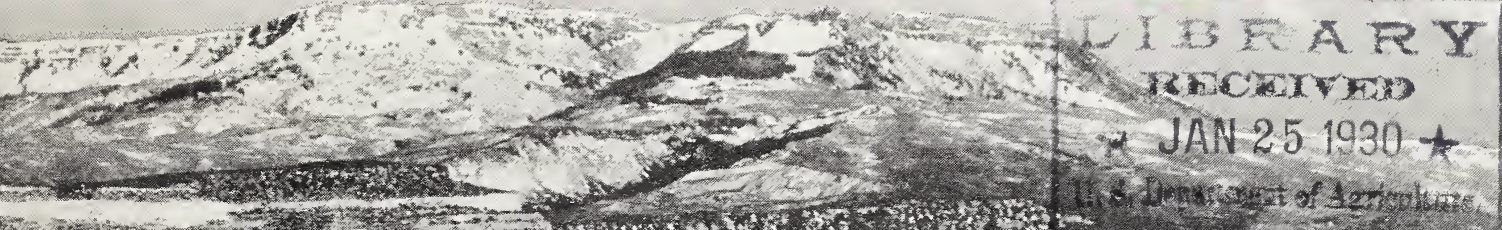

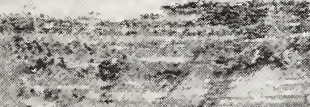

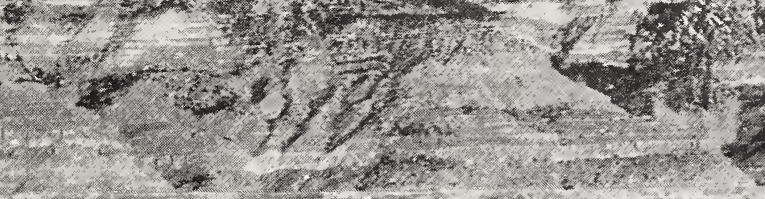

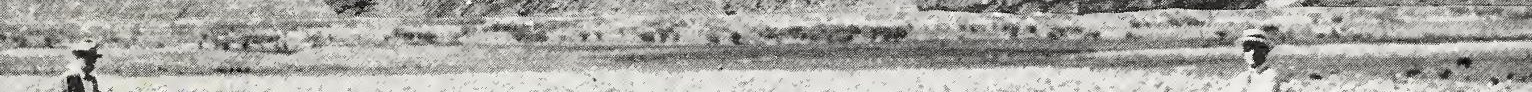

$\frac{1}{4}$

4

(1)

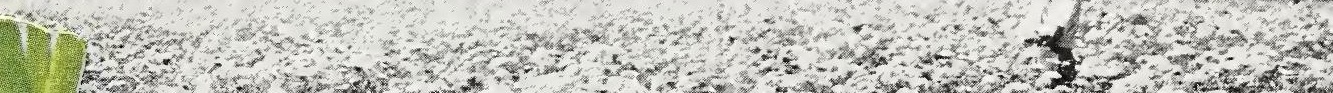

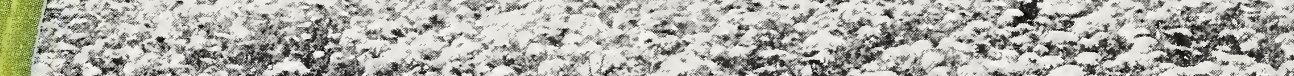

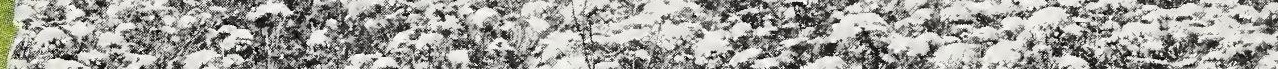

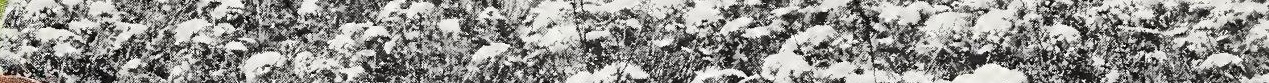
H. 1.7.

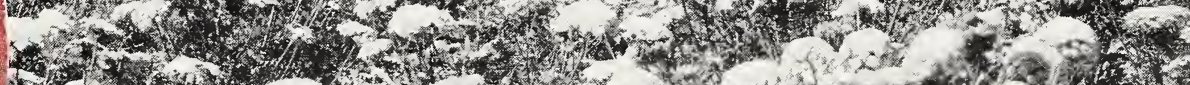

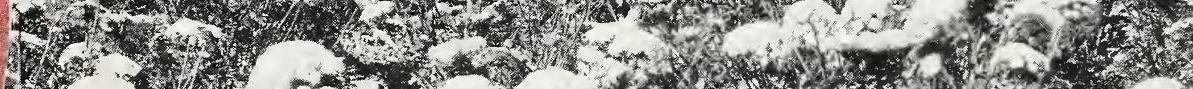
16.

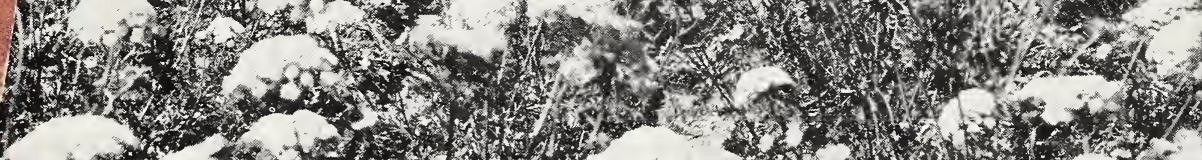

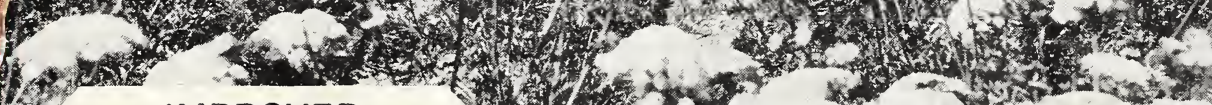

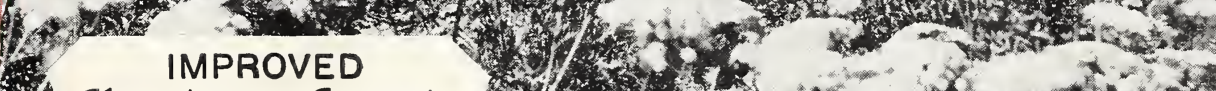

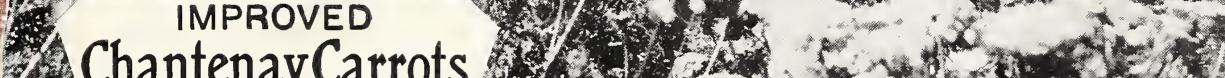

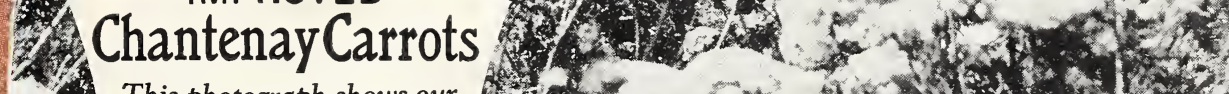
This photograph shows our
Seed Field in full bloom

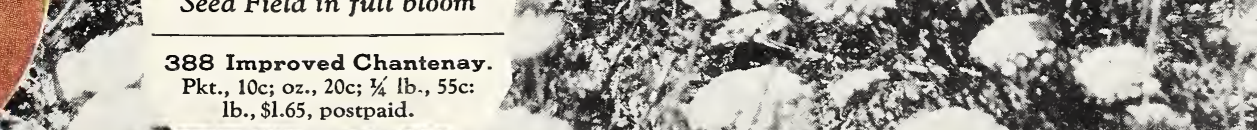

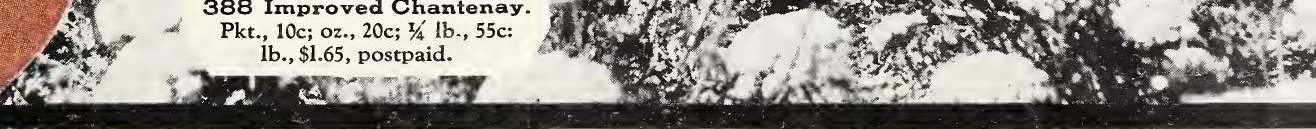
The Grand Junction Seed Co. GRAND JUNCTION - COLORADO In the Garden of the Rockies 


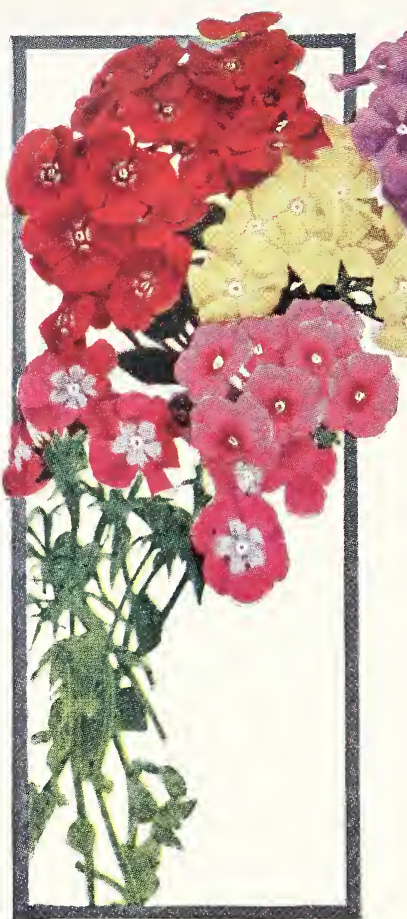

Phlox

\section{Special Offer}

one packet of each of the seven easily grown flowers illustrated on this page. These flowers will beautify your garden. Cover collection (; packets), postpaid for $60 \mathrm{c}$.

$60 c$

\section{Phlox}

Large Flowering Choice Annual Mixed

One of the showiest and most easily raised of all garden annuals. Flowers in June and continues $t o$ bloom until severe frosts. Height 15 to 20 inches. Pkt., $10 \mathrm{c} ; \mathbf{I} / 4 \mathrm{Oz}$. $40 \mathrm{c} ;$ oz., $\$ 1.25$, postpaid.

\section{Snapdragon}

New Giant Flowered Mixed This new type produces flowers of extraordinary size and a wonderful range of color. Snapdragons are easily grown indoors or out. Pkt., 15c;1/16 oz., 40c; I/8 oz., 60c, postpaid.

\section{${ }_{1023}$ Double Daisy}

\section{Bellis Perennis}

A plant of dwarf growth, once plant ed it produces a mass of blossom each Spring. Pkt., 10c; I/8 oz., 45c; I/4 oz., 75c, postpaid.

\section{Portulaca}

Rose Moss (Single Mixed)

A hardy annual floral carpet. Easily grown even in dry, sunny locations. Pkt., 10c; 1/8 oz., 20c; I/4 oz., 35c, postpaid.

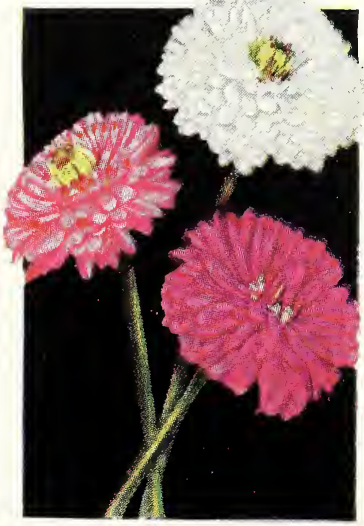

Double Daisy.

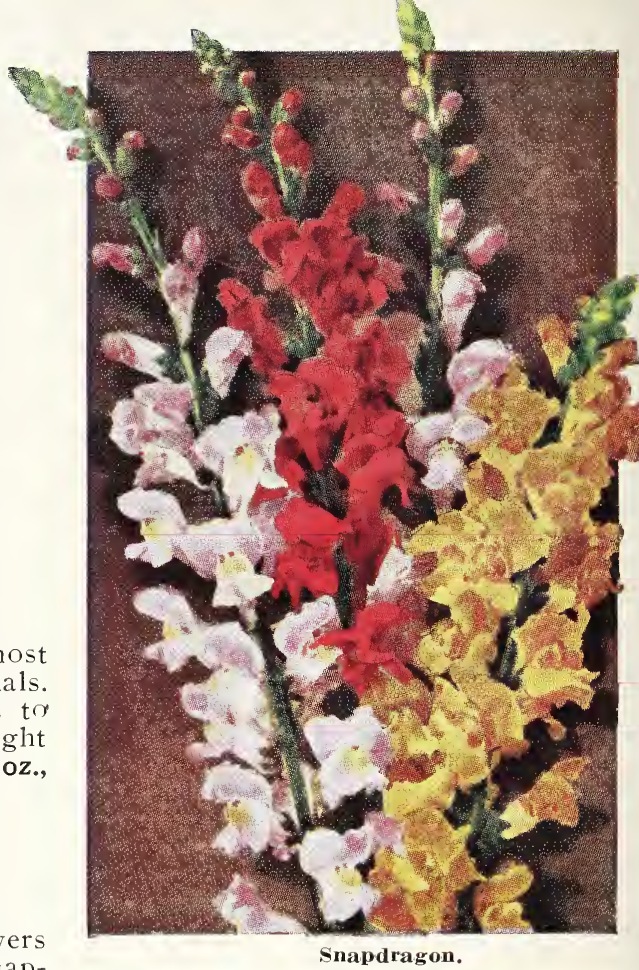

${ }_{1198}$ Salpiglossis

Gold Veined Mixed

One of the most attractive of hardy annuals. Height $2 \mathrm{1} / 2$ feet. Pkt., 10c; I/8 oz., 25c; $1 / 2$ oz., 70c, postpaid.

\section{Scabiosa}

Large Flowering Double Mixed

Finest cut flowers from an easily grown annual. Height $2 \mathrm{t} / 2$ feet. Pkt., 10c; I/4 oz., 20c; oz., 50c, postpaid.

\section{2:9 Verbena}

\section{Gigantea Mixed}

A new strain of compact plants, bearing immense floral trusses. Height 9 inches. Pkt., 15c; $1 / 8$ oz., 45c, postpaid.

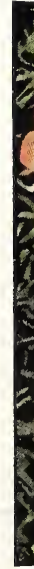

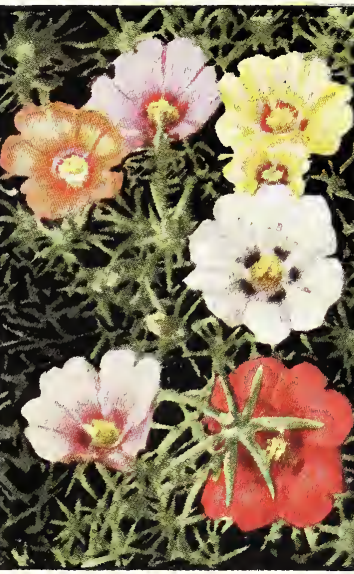

Portulaca.

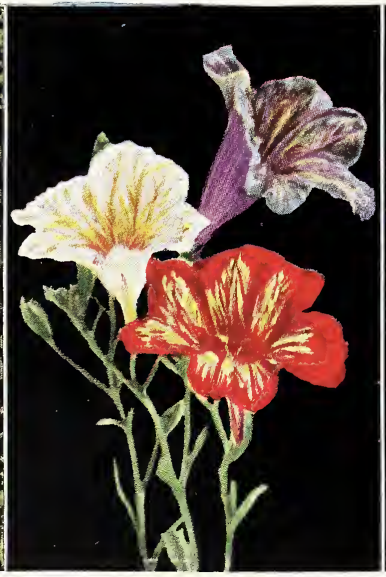

Salpiglossis.

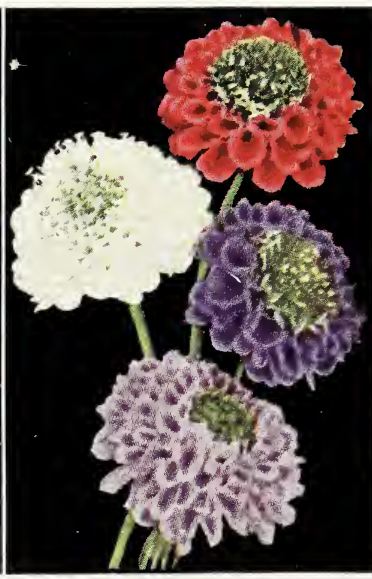

Scabiosa

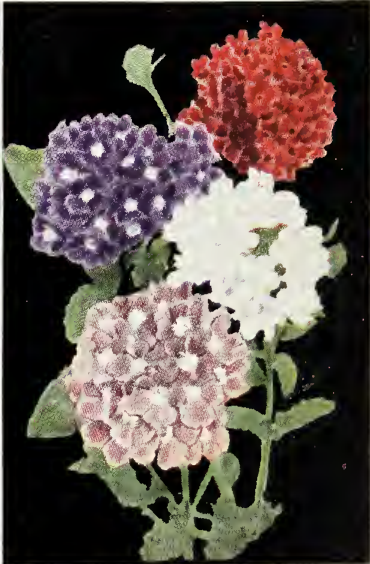

Verbena 


\section{If Delayed in Ordering, Send for New List Grand Junction Seed Company Price List of FIELD SEEDS}

By laying in our stock early we are able to offer you these attractive prices. The market is very firm on all field seed. We confidently look for much higher prices. Therefore we can only guarantee these prices to hold as long as our present stocks last. We sincerely recommend that you order early for we believe you will save money by doing so.

GRAND JUNCTION, COLO.

December 1, 1929.

Prices are strictly net, spot cash, no discount.

Prices, excepting on pound lots, are F: O. B. Grand Junction, Colo., customers to pay transportation charges; if wanted by parcel post, add extra for postage; see page 1 for parcel post rates. All prices subject to market changes and subject to stock being unsold on receipt of order.

We charge 50c each for seamless bags for Alfalfa, Clovers and Millets. Burlap bags are weighed in free on Coarse Grains and Feeds. Small seeds cannot be shipped in burlap bags, especially by parcel post. No charge for packing or drayage.

Our "Mile High" Brand Seed is the best seed obtainable, and is unexcelled in purity, vitality, plumpness and color. Should our prices appear higher than those of other houses, please send for samples and compare quality.

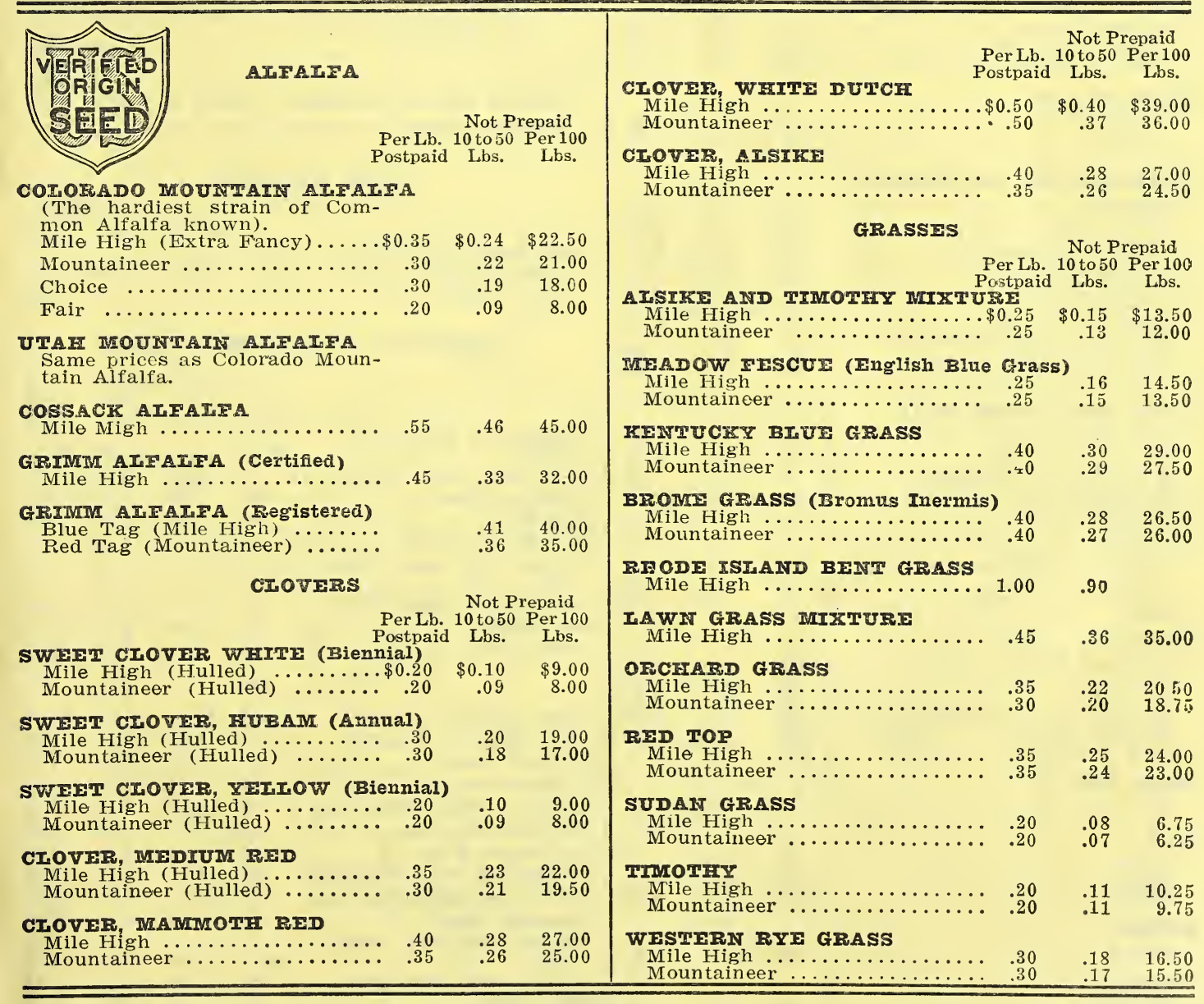

Prices on Quantity Lots are F. O. B. Grand Junction. If wanted by parcel post, add postage at zone rates. (See page 1). 


\section{PFRMANIMT PASTUEE MIZTUZXS}

Nor Not Prepaid 10 to 50 Per 100

Morton's Special, Irrigated $\ldots \ldots \$ 0.30 \quad \$ 0.21 \quad \$ 19.75$ Morton's (Without Sweet Clover)

Dry Light Soil $\ldots \ldots \ldots \ldots \ldots \ldots . .35$

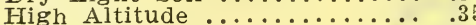

$\begin{array}{ll}.23 & 21.50 \\ .26 & 25.00 \\ .22 & 21.00\end{array}$

\section{MIIIETS}

Tennessee White Wonder ..... Japanese or Billion Dollar Grass

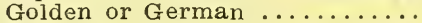
Siberian or Russian

Common

\section{ATKAIT GRAESIS}

Australian Salt Bush ....... 1.00

Western Rye Grass ........... .30

\section{GRAINS}

\section{BARIEY}

Colsess $\ldots \ldots \ldots \ldots \ldots \ldots \ldots \ldots$

White Hulless or Bald .......

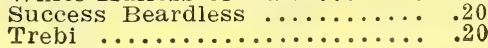

BHANS, FIETD (Fand Picked)

Mexican Pinto.............

Large White Navy ...........

Small Michigan Pea Navy ....

.20
.20
.20

Not Prepaid

Per Lb. 10 to 50 Per 100

Postpaid Lbs. Lbs.

\section{BUCTW TIA}

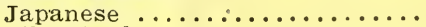

Silverhull $\ldots \ldots \ldots \ldots \ldots \ldots \ldots \ldots \ldots \ldots$

CORIy (Selected and Pecleaned)

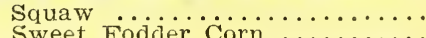

Fourteen Row Flint

Australian White Flint $\cdots \cdots \cdots$

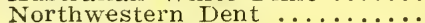

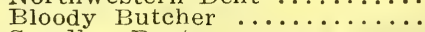

Swadley Dent

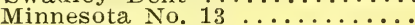

Colorado White Elephant .....

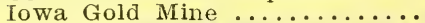

Reid's Yellow Dent ............

CORN (Kand Picked Šed)

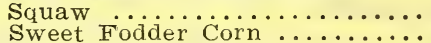

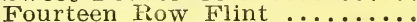

Australian White Flint ......

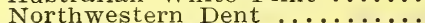

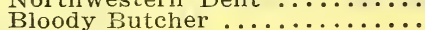

Swadley

Minnesota $i$ o. $13 \ldots \ldots \ldots \ldots \ldots \ldots$

Colorado White Elephant .....

Iowa Gold Mine .............

Reid's Yellow Dent ............

\section{OATS} Colorado Side $\ldots \ldots \ldots \ldots \ldots \ldots \ldots$ Victory $\ldots . . . \ldots \ldots \ldots . . . . . . . .$. Abundance or New Market .... Swedish select $\ldots \ldots \ldots \ldots \ldots \ldots$

PEAS, FIEID

San Luis Valley .......... .20

RYE

Rosen

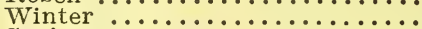

Spring...$\ldots \ldots \ldots \ldots \ldots \ldots \ldots$

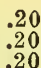

\section{FORAGI PIANTS}

Not Prepaid

Per Lb. 10 to 50 Per 100

Postpaid Lbs. Lbs.

FETPRTA $\ldots \ldots \ldots \ldots \ldots \ldots \ldots \ldots \$ 0.20 \quad \$ 0.06 \$ 5.50$

\section{TAFEIR CORIV}

Red $\ldots \ldots \ldots \ldots \ldots \ldots \ldots \ldots . .20 \quad .06 \quad 5.50$

Dwarf Black Hull, White .... $.20 \quad .06 \quad 5.50$

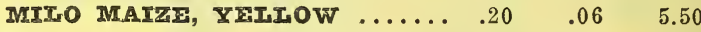

\section{SUGAT CANE}

Minn. Black Amber ............20 .05 4.25

FAPE, DWARE ESSEX $\ldots \ldots \ldots, \quad .25 \quad .15 \quad 11.50$

\section{SOIID ONIOF SETS-First Quality}

Not Prepaid

1 Lb. 4 Lbs. 8 Lbs, $32 \mathrm{Lbs}$

$1 \mathrm{Qt}, 4 \mathrm{Qts} .1 \mathrm{Pk} .1 \mathrm{Bu}$

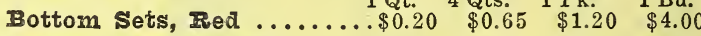

Bottom Sets, White ........20 $.70 \quad 1.30 \quad 4.50$

Bottom Sets, Yellow ..... $\quad .20 \quad .65 \quad 1.20 \quad 4.00$

Mountain Danvers Sets .... $\quad .20 \quad .70 \quad 1.30 \quad 4.50$

\section{VEGETABIE PTANTS}

Farāy Thountain Grown Plants. See pages 30 and 48

Texas Plants offered for early shipment. Shipped direct to you by Prepaid Express from Texas in ventilated baskets. These plants are grown from "Mile High" Seeds.

Per Basket by Prepaid Express

Crystal Wax Onion Plants. Basket of $6000 \ldots \$ 5.75$ Cabbage Plants. Basket of $3000 \ldots \ldots \ldots \ldots .4 .25$

SEED POTATOFS

\section{DEY IAND GROWN}

Per Lb. 10 to 50 Per 100 Postpaid Lbs. Lbs.

Irisll Cobbler $\ldots \ldots \ldots \ldots \ldots \ldots \ldots . \$ 0.25 \$ 0.04 \$ 3.50$

Early Ohio ............... .25 .04 3.50

\section{"ECONOMY" GUARANTIED FEEDS}

Baby Chick Eubtemilk

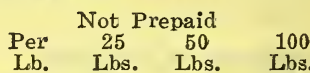

Mash ..............\$0.07 $\$ 1.35 \quad \$ 2.60 \quad \$ 4.75$ Baby Chick Scratch Feed .. $.05 \quad 1.05 \quad 2.00 \quad 3.50$ Growing Isash .............. $06 \quad 1.20 \quad 2.30 \quad 4.25$ Eᄑgg Mash ............... .05 $1.00 \quad 1.80 \quad 3.25$ Iren Scratch Feed ........ $.05 \quad .90 \quad 1.60 \quad 2.75$ Oyster shell, Baby Chick

Size .................... .04 $\quad .65 \quad 1.10 \quad 1.75$ Oyster Shell, Fen Size .... $.04 \quad .55 \quad .90 \quad 1.45$ Calf Ireal .................. $.08 \quad 1.60 \quad 3.00 \quad 5.75$ Dairy reed ................ .05 $.90 \quad 1.55 \quad 2.65$

Meat Scraps $\ldots \ldots \ldots \ldots \ldots \ldots \$ 0.07 \quad \$ 1.35 \quad \$ 2.60 \quad \$ 4.75$ Zone Neal for Poultry .... $.07 \quad 1.30 \quad 2.25 \quad 4.00$ Cracked Bone .............. .07 $1.30 \quad 2.25 \quad 4.00$ $\begin{array}{llllll}\text { Dried Buttermiık ......... } & .15 & 2.65 & 5.10 & 9.25\end{array}$ Charcoal, Baby Chick Size. $.10 \quad 1.75 \quad 2.80 \quad 5.50$ Charcoal, Hen Size ....... $.10 \quad 1.75 \quad 2.80 \quad 5.50$ Cottonseed Meal ...............06 $\quad .06 \quad 1.00 \quad 1.90 \quad 2.85$ $\begin{array}{lllll}\text { Cottonseed Cake, Nut Size . } & .06 & 1.00 & 1.90 & 2.85\end{array}$ Cottonseed Cake, Pea Size . $.06 \quad 1.00 \quad 1.95 \quad 2.95$ Flaxseed Mieal ............ .20 $3.50 \quad 6.50 \quad 12.00$ Granite Grit, Baby Chick

Size .................... $04 \quad .65 \quad 1.00 \quad 1.75$ Granite Grit, Fien Size .... $.04 \quad .60 \quad .90 \quad 1.50$ IZaffir Corn .............. $.05 \quad .95 \quad 1.60 \quad 2.75$ Linseed Oil Meal ......... $.08 \quad 1.35 \quad 2.25 \quad 3.85$ 


\section{GROWING “MILE HIGH” SEEDS}

Nountain Grown Seeds are grown under severe climatic conditions, hot days and cool nights. Surviving these severe conditions, tley not only. succeed under normal conditions, but also under adverse conditions, where less hardy seeds will fail.

The rich mountail valleys supply the soil, rich with natural fertilizing elements, to produce these strong, well tilled, plump seeds. The bright mountain sunshine fills the plants with vitality; grows, ripens and cures the seeds. The sparkling mountain streams furnish the irrigation water, which is applied to the crops at the proper times for good development and full growth of the seeds. These crops are not dependent for moisture on foggy, heavy air, with its attendant fungous diseases. These seeds come to you bright, clean and free from fungous growth.

All these seed fields are carefully rogued, that is, any off type plants are pulled out, and not allowed to mature. On biennial crops, such as Onion, Carrot, ete., the roots are all carefully sorted before being planted back for seed. On all crops continual selection and breeding is done each year to maintain and improve the types and to make the seeds suitable for the most critical planters. We like the critical customer, those who send in constructive criticism are indeed welcome. We appreciate your efforts to help us, to help our mountain climate and soils, to produce the finest seeds for the customer ordering "Mile High" seeds.

IOW AITITUDE PIANTERS. Seeds are like human beings, you cannot easily take them from a mild climate to a more severe climate, but can readily take them from a sereve climate to a mild climate. Florida, Mississippi, California and other southern states know how northerners enjoy your mild Winters. Mountain grown seeds have proven wonderfully successful in your states and several of your Agricultural Colleges now recommend Mountain Grown Seeds, but, of course, cannot specify any certain company's seed by name.
NORTHER N PLAWTERS. Mountain Grown Seeds furnish the early maturity necessary to your shorter season. The strong vitality to withstand a late cold snap or often a local soil disease.

EXPERIMENT STATIONS. We are in close touch with most Government and College Stations. We want to work with any we may have overlooked, to help you to help the planters of your state or district. Please write us.

\section{IN ORDERING}

IF POSSIBIE, USE OUR ORDER SHEET, filling out the blanks at the top. This will assist in the prompt filling of your order. Keep a copy of the ormake prompt adjustment.

OUR TFRMS are strictly cash with order. Remittance should be sent by postal or express money order, check, or registered mail to insure safe arrival. Small amounts may be sent in stamps.

PRICES on garden and flower seeds usually hold good throughout the Spring, we reserve the right to revise these prices after our present stocks are exhausted or late in the year.

PTEASE ORDIR EARIY. Dont wait until some of our stocks are sold out, and you are rushed, and we are rushed. It's twice as hard to give satisfaction when everyone is in a hurry.

FIEID SFED AND FEFD PRICES vary with the markets. If you are delayed in ordering, please send for a new price list.

IVARKRT GARDENEES AND IARGE PIANTFRS should write for special prices on large quantities.

We sell our seeds and other goods with the understanding that if not found perfectly satisfactory they may immediately be returned at our expense and your money will be refunded.

Success in gardening and farming depends largely upon soil, cultivation and climatic conditions over which we have no control.

THE GRAND JUNCTION SEED COMPANY gives no warranty express or implied, as to description, quality, productiveness or any other matter of any seeds, bulbs or plants it sells and will not be responsible for the crop.

If goods are not accepted on the above terms, notify us at once, and we will give instructions for disposition of goods.

OUR R?BSPONSIBIIITY is well established; we invite you to refer to R. G. Dun \& Co., Bradstreet's, the Produce Reporter Blue Book, our Postmaster, the U. S. Bank of Grand Junction, the Grand Valley National Bank of Grand Junction, or any bank in estern Colorado.

PARCEI POST RATIS AND NOTES. We will not send Plants, Bulbs, or any perishable items

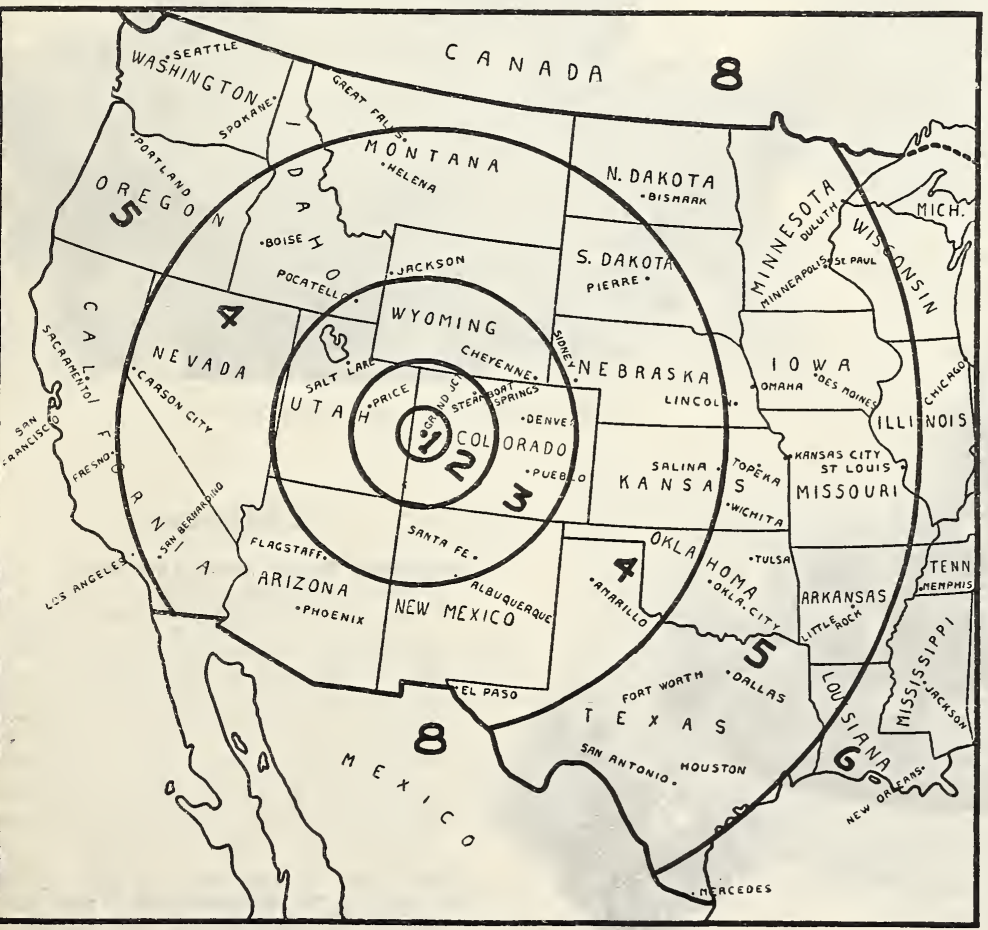
seeds C. O. D. when double the amount of the transportation charges accompanies the order.

EXPRESS OR FREIGHT is often cheaper than parcel post. Unless you specify how to ship we will ship by whichever way we believe to be cheapest and best.

INSURATCE AND SAFP DEIIVERY. We insure without extra charge and guaranteo safe delivery of all seeds, whether shipped by mail, express or freight.

It.is against the postal laws to ship poisons, such as poisonous insecticides, Semesan, O1 any seeds treated with mercuric disinfectants by mail. Please do not ask us to break Please do
the law.

\section{PARCEI \\ POST}

RATES

First Fach

Loca

1st Zone pound additional fraction fraction

one.. $.7 \mathrm{c}$

rd Zone .... 8c

4 th Zone .... 8 c

5 th Zone... 9c

6 th Zone.. .1 10

7 th Zone.. $.112 \mathrm{c}$

8th Zone .... 13c

Local rate applies to Grand Junction rural routes only.

Limit of weight of each package for first three zones is 70 lbs. 4th to 8 th zones 50 lbs. Do not forget to allow for weight of package, wrapping or bags. 


\section{NEW VARIETIES OF SPECIAL MERIT}

\section{Cabbage}

366 Farliest of All. (75 days). The earliest round head Cabbage, earlier than Early Jersey Wakefield and two weeks earlier than any of the old standard round head varieties. Solid heads are smaller than Copenhagen Market and just right size for family use. The quality is fully equal to Copenhagen Market The outer leaves are small-

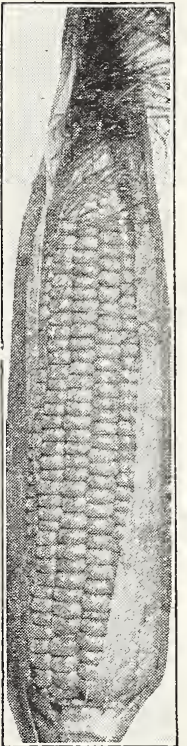

Golden Sunshine Sweet Corn.

er, allowing of closer planting. In our trial plots almost every plant has produced a head, solic as lead and did not burst. We certainly recommend Earliest of All to the home gardener and the market gardener. Pkt, 15c; $1 / 2$ oz, $45 \mathrm{c} ; 0 \mathrm{z}, 65 \mathrm{c} ; 1 / 4 \mathrm{lb}, \$ 1.90$ ib, $\$ 6.00$, postpaid. Not prepaid, $5 \mathrm{lbs}, \$ 25.00$.

\section{Sweet Corn}

439 Golden Sunshine. (60 days). The same flavor and same color as Golden Bantam, but 10 days earlier. The ears are also larger, being 12-rowed instead of 8 . Sunshine Corn is ready as early as the early white corns, it is early enough to be off the market before Golden Bantam is ready. Dr. Yeager of the North Dakota Experiment Station developed Golden Sunshine by crossing Golden Bantam with Portland Early Market. We obtained our original seed direct from Dr. Yeager. The plant is very dwarf and the ears close to the ground. We have grown a large seed acreage of Golden Sunshine, anticipating a big demand; do not disappoint us by missing this excellent variety. Plkt, 10c; $1 / 21 \mathrm{~b}, 25 \mathrm{c} ; 1 \mathrm{~b}, 40 \mathrm{c}$, postpaid. Not prepaid, $1016 \mathrm{~s}, \$ 2.20$ $251 \mathrm{bs}, \$ 5.00$.

\section{Wonderberry}

A wonderful, prolific plant of the tomato family. Very hardy; when once established the bushes will come up each year from odd seeds dropped on the ground. When ripe the berries are almost an inch in diameter, of shining black color. Fruit is non-edible until fully ripe but when ripe is wonderful for pies, preserves and jam. A very heavy yielder, the plants being just loaded with these berries. Requires no care or cultivation. Plrt, 10c; oz, 50c, postpaid.

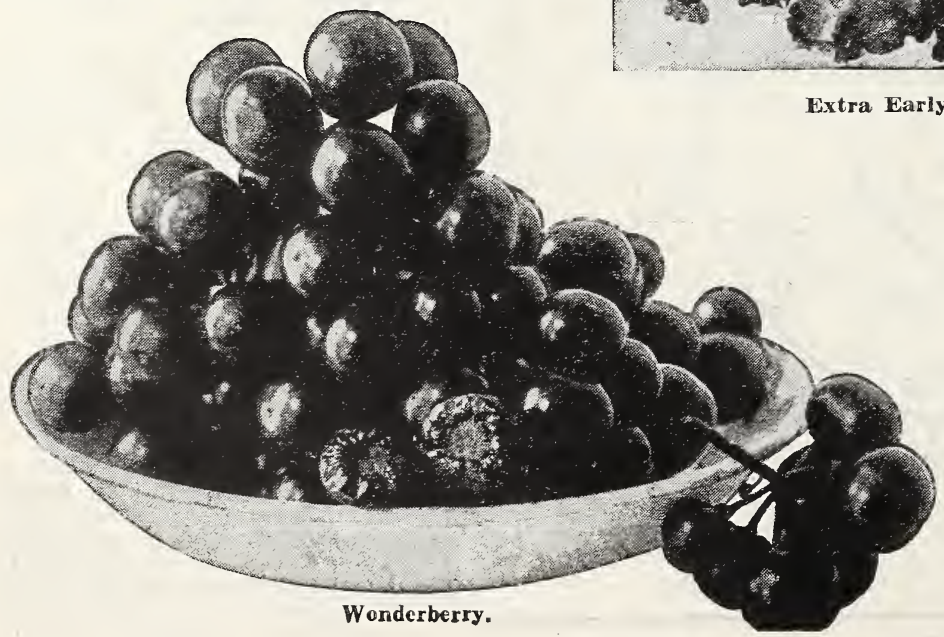

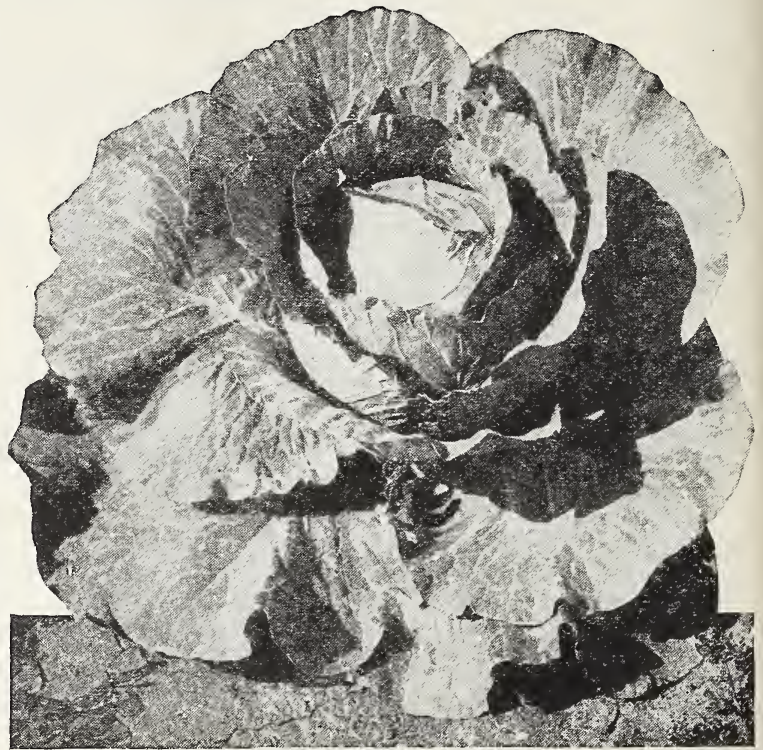

Earliest of All Cabbage.

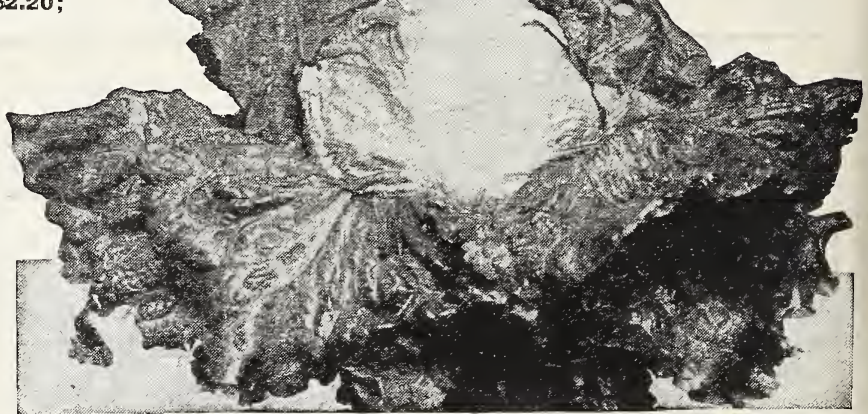

Extra Eariy 5084 New York Lettuce.

\section{Lettuce}

543 Extra Early 5084 New York. (70 days). A brand new strain of New rork Lettuce selected for extreme earliness. It produces well rounded, tight, solid heads about two weeks earlier than any other known strain and the top of the head has a well grown leaf which protects it greatIy from sunscald. This Lettuce belongs to the class known to the seed trade as New York and to most of the produce trade as Iceberg; the new 5084 strain has indeed caused a sensation in all the growing sections where it has 15c; $1 / 2$ oz, 30c; oz, 45c; $1 / 41 \mathrm{lb}$ $\$ 1.10 ; 1 \mathrm{~b}, \$ 3.20$, postpaid. Not prepaia, $51 \mathrm{bs}, \$ 14.00$; $10 \mathrm{lbs}, \$ 27.00$. 


\section{Cantaloupe}

418 ward's Ideal ( 80 days). A careful selection of the perfectly round, heavily netted, Rocky Ford type Cantaloupe. It has the very best flavor, being very sweet and delicious. It ripens clear to the skin. Ward's Ideal runs vely uniform to standard size and with no pony melons. These Cantaloupes are perfectly round, have no ribs and have a very heavy netting, making them ideal for shippers. The Ideal has thick, orange flesh, free from stringiness, and a small seed cavity. Like all Cantaloupes it remains in good condition for a much longer time than Muskmelons; you do not have to be an expert to know when to pick Cantaloupes. Plkt, 10c; oz, 25c; $1 / 41 \mathrm{~b}, 70 \mathrm{c}$; 1b, $\$ 2.00$, postpaid. Not prepaid, 5 Ibs, $\$ 8.00 ; 10 \mathrm{lbs}, \$ 14.75 ; 25 \mathrm{lbs}$, $\$ 32.50$.

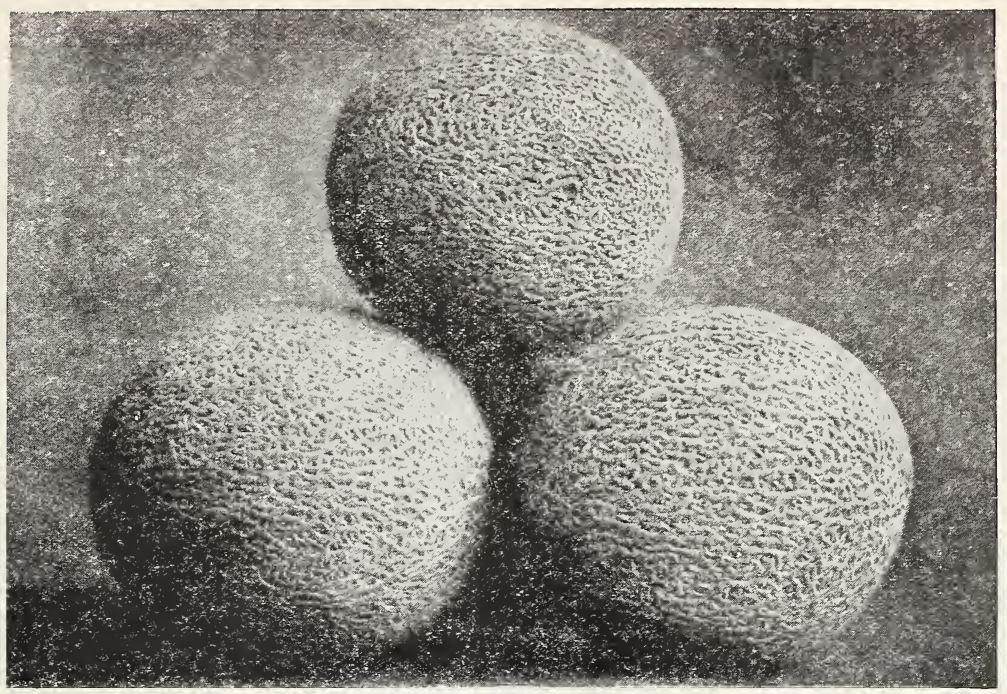

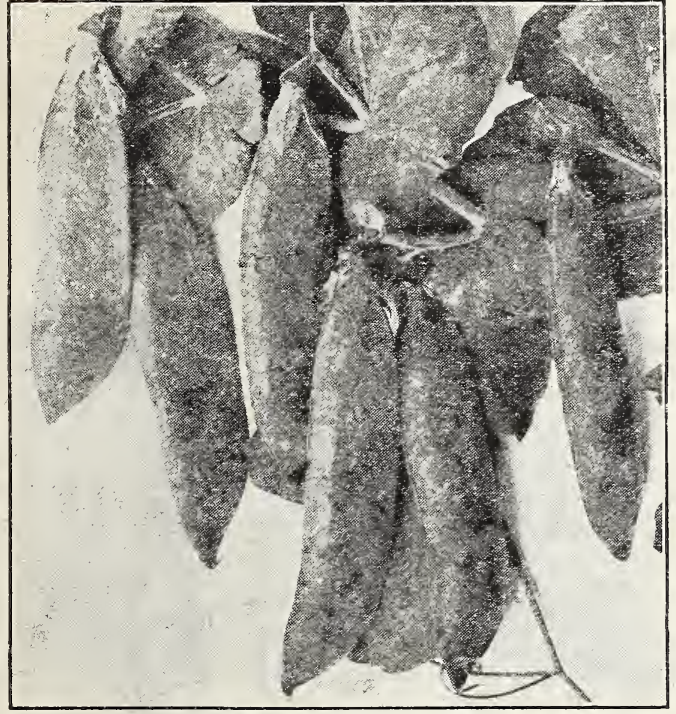

Ward's Bestever Peas.

Ward's Ideal Cantaloupe.

\section{Peas}

598 Ward's Bestever. (70 days). The best variety of the Gradus type and has been very popular ever since we introduced it in 1924. It is so hardy that it can be planted much earlier than Gradus and can be picked several days before that variety is ready. The large pods are more even in size, very attractive in appearance, and usually contain 9 dark green peas of extra fine quality. Bestever is more dwarf than Gradus, the sturdy vines growing 2 feet high. Bestever has such a fine flavor that many of our customers plant it in succession for early, second early, and main crop Peas Pods 4 inches long, very broad, pointed and well filled. Pkt, 10c;1/2 1b, 30c; 1b, 50c, postpaid. Not prepaia, 5 1bs, $\$ 1.75 ; 25$ lbs, \$6.00; 100 lbs, \$21.25.

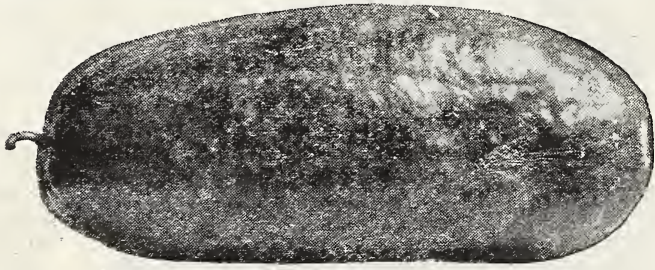

Rio Grande Watermelon.

\section{Watermelon}

752 Ward's Rio Grande. (70 days). An extremely early Melon and the finest, sweetest flavor of all the early Melons. You like Watermelons; you like them better if you can get them real early in the season; if that is what you want in a Waterinelon we know you will like the Rio Grande. It is a long Melon with a thin, dark green rind; it is too tender to stand shipping but it is ideal for home markets and for your garden. We have had several Rio Grande Melons weighing over 40 pounds. It is the best early Wateroz, 350; 1/ 1b, \$1.00; 1b, \$2.50, postpaid. Not prepaid, $5 \mathrm{lbs}, \$ 10.00 ; 10 \mathrm{lbs}$, $\$ 18.75$.

\section{Pepper}

624 sunnybrook. (110 days). An improved Pimento. As sweet as an apple, and the flesh is unusually thick. Medium size, 3 inches thick by $21 / 4$ inches deep, just right size for stuffing. The very best Pepper for canning. Small. bushy plants are just loaded with deep green fruits which turn a bright glossy scarlet. Pkt, 10c; $1 / 2$ oz; 35c; oz, 55c; $1 / 41 \mathrm{~b}, \$ 1.50 ; 1 \mathrm{~b}, \$ 4.00$, postpaid. Not prepaid, $5 \mathrm{lbs}, \$ 18.60$.

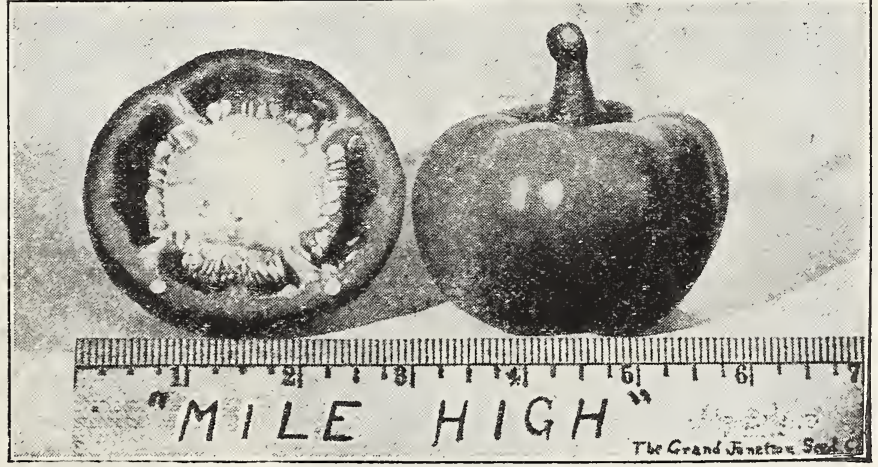

Sunnybrook Pepper. 


\section{Mammoth Garden Collection}

\section{A Complete Vegetable Garden $\$ 1.60$
Postpaid, for $\$ 1.00$}

Cost of Items if Purchased separately, $\$ 2.60$.

We put these collections up before the busy season opens, and in this way we are able to sell them at lower prices. The varieties selected for this assortment are the most popular varieties and will give every satisfaction. We can make no changes in the assortment.
$1 / 2$ lb. Beans, Burpee's Stringless.

1 pkt. Beans, Improved Golden Thax

1 oz. Beet, Canner's Favorite.

1 pkt. Cantaloupe, Ward's Ideal.

$1 \mathrm{oz}$. Carrot, Improved Chantenay.

$1 / 2$ lb. Sweet Corn, Golden Bantam.

$1 / 2$ lb. Sweet Corn, Stowell's Evergreen.

1 pkt. Cucumber, Improved Long Green.

1 pkt. Cucumber, Prolific Gem Pickling.
1 pkt. Lettuce, Ward's Grand Rapids.
1 pkt. Lettuce, Special Strain New York.
1 oz. Parsnip, Ward's Marrowfat.
$1 / 2$ 1b. Peas, Alaska.
$1 / 2$ lb. Peas, Ward's Bestever.
1 pkt. Radish, Sparkler.
$1 \mathrm{oz}$. Radish, White Icicle.
$1 \mathrm{oz}$. Spinach, Mountain Ever-
green.
1 pkt. Watermelon, Rocky Ford.

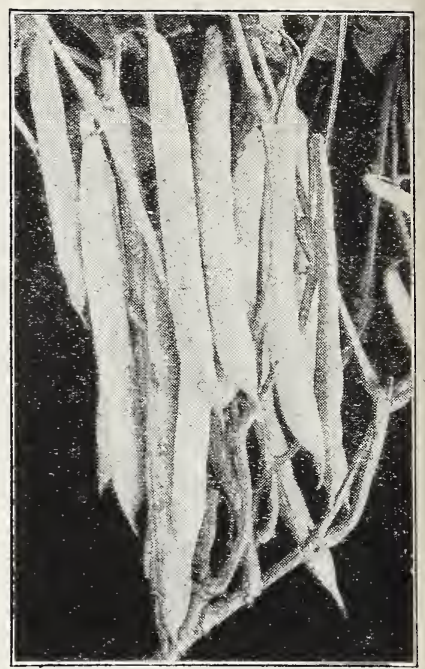

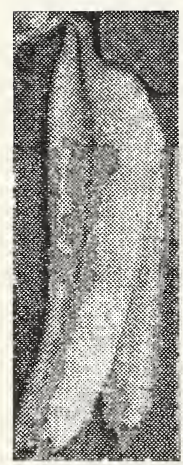

Davis White Wax Beans.

\section{Mountain Grown Seed Beans}

Free from fungous growth, this seed comes to you plump, clean and healthy. Grown in our rigorous mountain valleys on rich mountain soil and with clear irrigation water supplied at the proper time to develop healthy seed. All seed fields are carefully gone over, any off-type plants pulled out and destroyed. This is, indeed, seed for the particular planter.

Culture One pound to 100 feet of row; 35 to 40 pounds per acre.

Beans are among the comparatively few vegetables that yield well on even poor soil, although greatest crops are gathered in moderately rich loam. Sow, after the ground is quite warm, in rows not less than 18 inches apart. Plant the seeds three inches apart, and $11 / 2$ inches deep. Never walk between the rows or attempt to cultivate them or to gather the crop while the vines are wet, as this will spread rust.

\section{Wax or Yellow Podded Beans}

The Wax-Podded varieties have a buttery flavor which the Green-Podded do not have, but usually people tire of the Wax varieties sooner than the green pod; to many the Wax pods have a more attractive appearance.

284 Improved Golden Wax. (53 days). A real early, stringless type that is indeed a favorite for the home garden. Superior quality, flat, straight pods, 4 inches long. Light colored vines grow 10 inches high. Pkt, 5c; $1 / 2$ 1b, 25c; 1b, 40c, postpaid. Not prepaid, $10 \mathrm{lbs}, \$ 2.85 ; 25 \mathrm{Ibs}, \$ 6.50$. 280 Currie's Rust-Proof Black Wax. (55 283 Sure Crop Black Wax. (57 days). second early home garden variety. Dark,

287 Davis White Wax. ( 52 days). An days). Early, hardy and practically
rust-proof. Attractive appearing light yellow pods, $51 / 2$ inches long, flat and straight. Popular market variety, not stringless, Dark vines, 13 inches high. stringless. Dark vines, 13 inches Not prepaid, $10 \mathrm{lbs}, \$ 3.10 ; 25 \mathrm{lbs}, \$ 6.50$. Vigorous grower, stringless and rustproof. A prolific cropper with deep yelproof. A prolific cropper with deep yel-
low pods $61 / 2$ inches long, flat and straight. Popular for market and as a vigorous vines, 15 inches high. Plet, 10c; 1 1b, 25c; 1b, 45c, postpaid. Not prepaja, 10 lbs, $\$ 3.15 ; 25$ lbs, $\$ 6.25$. extremely early variety. Very popular market variety, because of the attractjve light yellow or almost white pods. Pods 6 inches long, flat and straight, not stringless. Dark vines, 15 inches high. Pkt, 10c; 1/2 1b, 25c;10, 40c, postpaid. Not prepaid, $10 \mathrm{los}, \$ 2.85 ; 25 \mathrm{los}$, $\$ 6.25$.

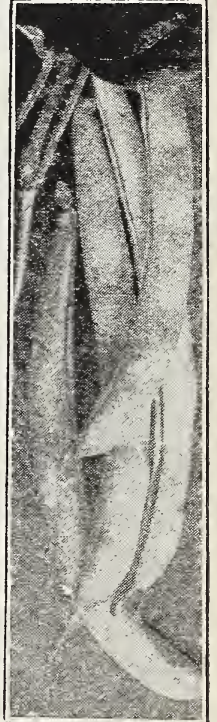

81 Round Poà Ridney Wax or Brittle Was.

Round Pod Kidney Wax Beans. Bean of superb quality and surprisingly productive. Pods are very tender, entirely stringless and meaty; well suited to ali purposes, home gardens, markets and the finest Wax Pod Bean for canning. Deep yellow, stringless pods, 5 inches long, round and slightly curved. Dark vines, 15 inches high. Pkt, 10c; $1 / 2$ 16, 35c;1b, 55c, postpaid. Not prepaid. 10 10s, $\$ 4.25 ; 251 \mathrm{bs}, \$ 10.00$.

286 Fencil Poả Black Wax. (59 days). Stringless, thick, meaty pods; an excellent second early variety for home garden or market. A vigorous growing and productive sort. Deep yellow, round pods are 6 inches long, round, slightly Deep yellow, round pods are 6 inches long, round, slighty vigorous vines, 15 inches high. Pit, $5 \mathrm{c} ; 1 / 2 \mathrm{Jb}, 20 \mathrm{c}$ : 15, 35c postpaid. Not prepaid. 10 10s, $\$ 2.50 ; 25$ 1bs, $\$ 5.75$. 


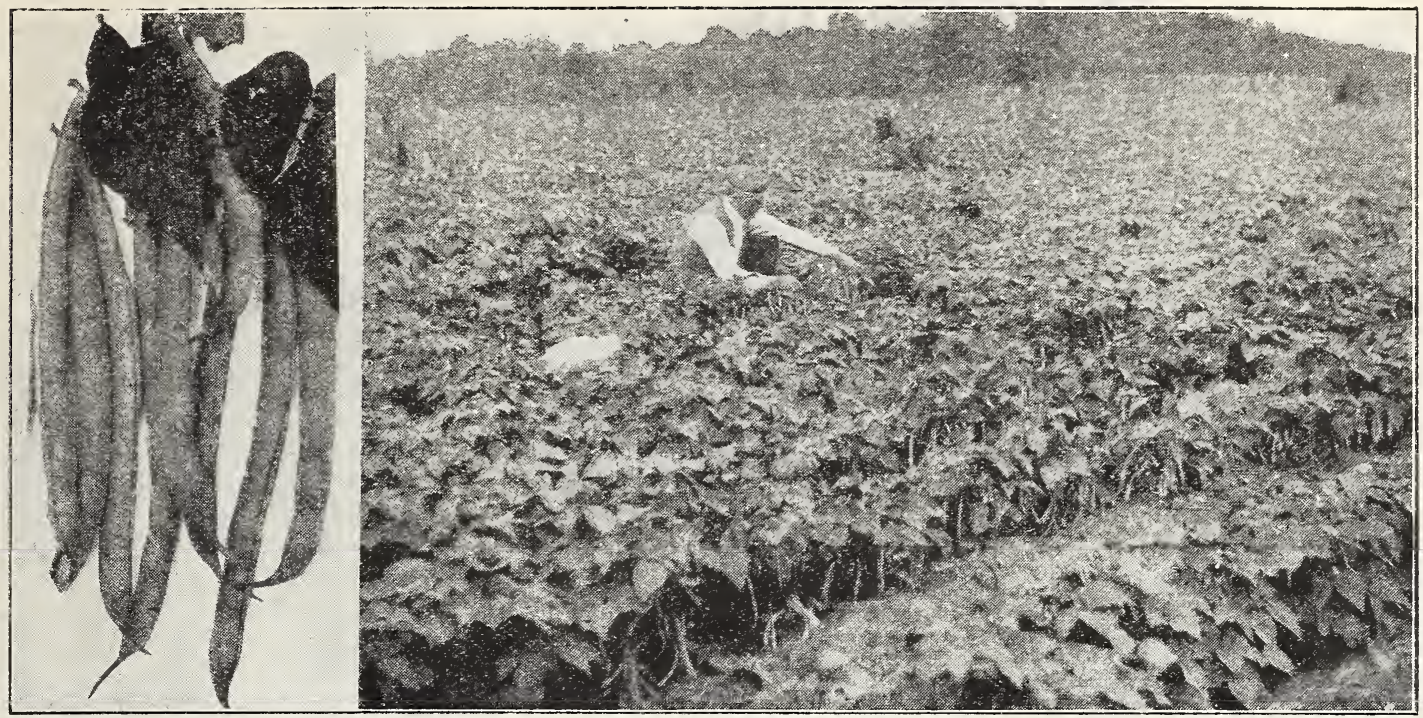

Giant Stringless Beans.

\section{Dwarf Green Pod Beans}

What is more delicious than fresh, brittle, stringless Beans right from your own garden? And don't fail to plant some Beans this year to can. 'They can be planted late, taking the place of some early crop. Canned Beans taste as good as fresh ones and will certainly help out on the table next Winter.

Green Podded Beans are as a rule more productive than the Wax or Yellow Podded varieties, besides being less susceptible to unfavorable conditions of soil and climate.

266 Burpee's Stringless. (53 days). Very early variety with handsome, thick, tender, stringless pods. An all-purpose bean, a favorite in hom gardens, on the market, or for canning. A strong grower. Excellent qual-

ity, round pods, 5 inches long, slightly curved, stringless and a good 15 ib, 25c; 1b, 40c, postpaid. Not prepaid, $10 \mathrm{lbs}$, $\$ 3.10$; 25 lbs, $\$ 6.75$.

267 Giant Stringless. (55 days). Larger than Burpee's Stringless and of the same fine quality. Early, hardy and productive. Widely used as a market variety, coming into popularity for the home garden, and one of the very finest canning varieties. The pods are so thick and meaty as to be saddle-backed, not of quite as pretty appearance, as the pods indent around the seeds. Light green pods, 6 inches long, round, nearly straight and entirely stringless. Light green vines, 15 inches high. Pkt, 10c; 1/2 lb, $25 \mathrm{c} ; 1 \mathrm{~b}, 40 \mathrm{c}$, postpaid. Not prepaid, $10 \mathrm{lbs}, \$ 2.75 ; 25 \mathrm{lbs}, \$ 6.25$.

261 Bountiful stringless. (55 days). Early, remarkably productive and fine long, high quality stringless pods. A new variety which has already found favor with market gardeners and will soon be popular in home gardens. Bears for a long season and is often called a continuous bearer. Pods are thick, very uniform in shape, solid and meaty. Semi-round pods, $71 / 2$ inches long, straight, stringless, and a good green color. Light colored vines 15 $1 / 2 \mathrm{lb}, 30 \mathrm{c} ; \mathrm{lb}, 45 \mathrm{c}$, postpaid. Not prepaid, $10 \mathrm{lbs}, \$ 3.35 ; 25 \mathrm{lbs}, \$ 7.40$.

264 Full Measure. (58 days). A new, high quality, stringless bean. A second early, all-purpose variety; for home gardens or market and one of the best canning varieties. Tender, dark green pods, 6 inches long, round and crease-backed, nearly straight and quite stringless. Coarse, dark green vines, 15 inches high. Pkt, $10 \mathrm{c} ; 1 / 2 \mathrm{lb}, 35 \mathrm{c} ; 1 \mathrm{~b}, 55 \mathrm{c}$, postpaid. Not prepaid, $10 \mathrm{lbs}, \$ 4.35 ; 25 \mathrm{lbs}, \$ 10.25$.

271 Black Valentine. (53 days). An extra early variety of beautiful appearance and a favorite market sort. Slender, straight pods, 51/2 inches long, nearly round, good green color, fine quality but stringy. Dark green vines, 13 inches high. Pkt, 5c; $1 / 2 \mathrm{lb}, 20 \mathrm{c} ; 1 \mathrm{~b}, 35 \mathrm{c}$, postpaid. Not prepaid, $10 \mathrm{lbs}$, $\$ 2.40 ; 25$ lbs, \$5.25.

270 Improved Early Red Valentine. (55 days). Extremely attractive appearance has long made this a favorite market sort. Fine green color and when picked at the proper time they are tender and fine flavored, but when older they become stringy. Straight, nearly round pods, $53 / 4$ inches long. Dark vines, 15 inches high. Pkt, 5c; $1 / 21 \mathrm{~b}, 20 \mathrm{c} ; 1 \mathrm{~b}, 35 \mathrm{c}$, postpaid. Not prepaid, 10 lbs, $\$ 2.40 ; 25$ lbs, $\$ 5.25$.

265 Refugee, or 1000 to 1. (77 days). A strong grower and the most productive of all dwarf varieties. Good quality but somewhat stringy. Used mainly for canning. Light green pods, $5 \frac{1 / 2}{2}$ inches long, round and slightly curved. Robust, dark green vines, 15 inches high. Pkt, 5c; 1/2 1b, 25c; lb, 40c, postpaid. Not prepaid, $10 \mathrm{lbs}, \$ 3.25$; 25 lbs, $\$ 6.25$.

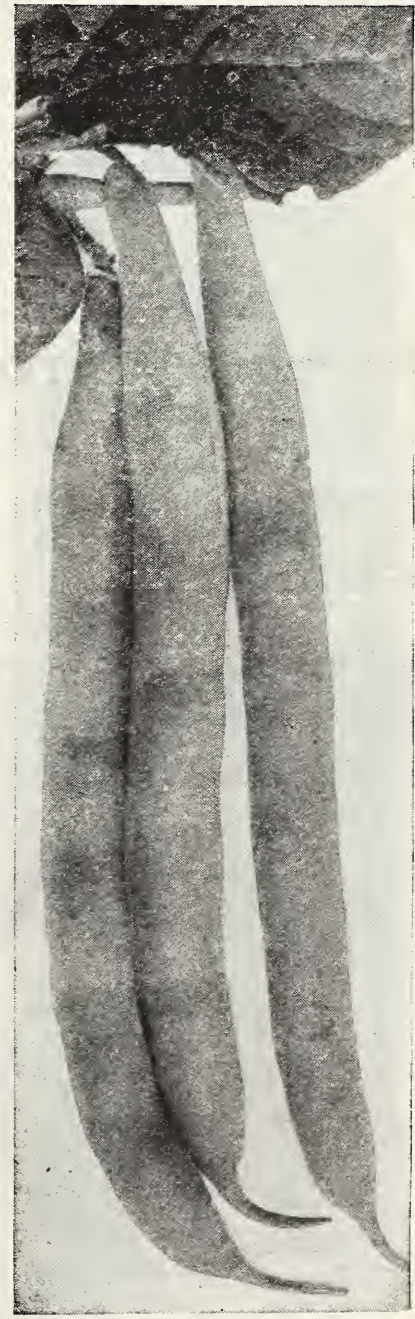

Bountiful Stringless Beans. 


\section{Pole Beans}

When properly staked up Pole Beans require less room than the bush varieties. Hence they are largely used for small gardens, where the space is limited. Pole Beans are much heavier yielders than the bush varieties, and Ward's Prolific is by far the heaviest yielder of all.

Cuiture. Set poles 4 feet apart each way, and plant 6 beans around each pole. One pound to 75 hills.

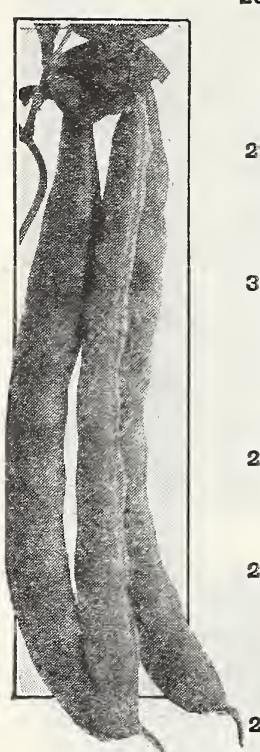

995 Kentucky woncler, Old Eomestead. (78 .days). Early, productive variety for home gardens, markets and canning. Good green pods, 9 inches long, curved and nearly round. Good quality when young; has some string when fully grown. Fkt, 5c; 1/2 Ib, 20c; $1 \mathrm{~b}, 35 \mathrm{c}$, postpaid. Not prepaid, $10 \mathrm{lbs}, \$ 2.30 ; 25 \mathrm{lbs}$, $\$ 4.50$.

292 White Seed IKentucky wonder. (78 days). Similar in growth to the Kentucky Wonder, but the pods are long, straight, and entirely stringless. The white beans are also fine for Winter use. Pkt, 5c; $1 / 2$ 1b, $25 \mathrm{c}$; 1b, 35c, postpaid. Not prepaid, $10 \mathrm{lbs}, \$ 2.40$; 25 ibs, $\$ 4.75$.

300 Ward's Prolific. The heaviest yielding bean grown. Enormous vines, hills should be 4 feet apart and well supported to attain a full growth. Should be planted early, once they commence to bear the vines will be loaded until frost. The medium sized green pods are stringless and tender, making an excellent snap bean, with a delightful, distinct flavor. Pkt, 10c; 1/2 1b, 25c ; $1 \mathrm{~b}, 40 \mathrm{c}$, postpaid. Not prepaid, $5 \mathrm{lbs}, \$ 1.60$.

297 Iazy Wife. (78 days). A heavy yielding main crop green snap bean. The pods, borne in large clusters, are thick, fleshy and stringless. The dry white beans are excellent for Winter use. Pkt, 5c; $1 / 21 \mathrm{lb}, 20 \mathrm{c} ; \mathbf{l b}$ $35 \mathrm{c}$, postpaid. Not prepaid, $10 \mathrm{lbs}, \$ 2.30 ; 25 \mathrm{lbs}, \$ 4.75$. 294 Grand Valley White Igg. ( 82 days). Sometimes known as the Mountain Lima, because of the large

thick pods. The vines make an enormous growth and are literally covered with pods very early in the season. The pure white oval shaped seeds are 5 times the size of the common Navy Bean. Flrt, 10c; $1 / 2 \mathrm{lb}, 25 \mathrm{c} ; 1 \mathrm{~b}, 45 \mathrm{c}$, postpaid. Not prepaid, 5 lbs, $\$ 1.50$.

296 Kentucky wonder wax. (76 days). A heavy yielding wax podded pole bean, for home or market gardens. Curved, yellow,
flat pods grow io inches long, meaty and of good flavor, but Wentucky Wonder. show strings. Pkt. 5c; 1/2 Ib, 20c; 1b, 35c, postpaid. Not prepaid, $10 \mathrm{lbs}, \$ 2.60$; $25 \mathrm{lbs}$. $\$ 5.25$.

299 Scarlet Runner. Of quick growth, bearing large and showy sprays of bright scarlet flowers. The pods are tender and tasty while young. Plt, $10 \mathrm{c} ; 1 / 2 \mathrm{lb}, 25 \mathrm{c} ; 1 \mathrm{~b}, 40 \mathrm{c}$, postpaid. Not prepaid. $5 \mathrm{lbs}, \$ 1.60$.

\section{Lima Beans}

One pound to 75 hills. Plant after the weather has become real warm. Do not cover too deeply. When irrigation is available, it is best to make a crease and run the water through first, then sow the beans in the crease and cover with dry soil.

320 Henderson's Bush. (65 days). The Baby Lima or Butter Bean. Matures in all localities. Very productive and a sure cropper. Beans and pods are small. Tender and buttery flavor. Pkt, 10c; 1/2 1b, 20c; 1b, 35c, postpaid. Not prepaid, $10 \mathrm{lbs}, \$ 2.40 ; 25 \mathrm{lbs}, \$ 4.75$.

315 Eurpee's Bush. (90 days). An immense yielder, the original type of dwarf large-seeded Lima. Pkt, 10c; 1/2 1b, 25c; 1b, 40c, postpaid. Not prepaia, $10 \mathrm{lbs}, \$ 2.90 ; 25 \mathrm{lbs}, \$ 6.50$.

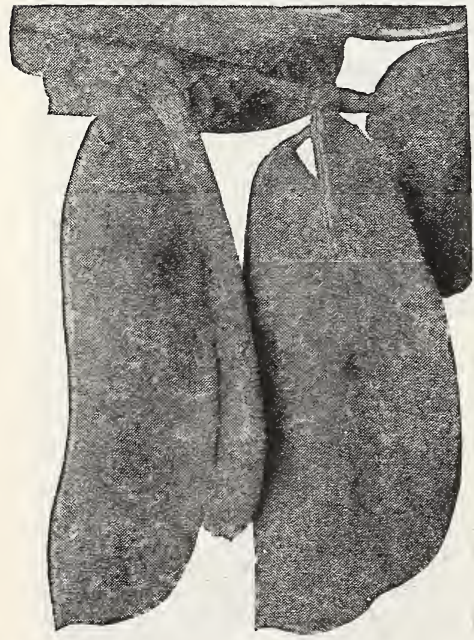

Elenderson's Bush Lima.
316 Burpee's Improved Bush. (82 days). Larger than Burpee's Bush and thicker pods. Plants grow 30 inches high and pods measure 5 to 6 inches long. Excellent flavor. Plit, 10c; $1 / 2,1 \mathrm{~b}, 25 \mathrm{c} ; 1 \mathrm{~b}$, $40 \mathrm{c}$, postpaid. Not prepaid, 10 1bs, $\$ 3.00$; $25 \mathrm{lbs}, \$ 6.75$.

317 Fordhook Bush. (80 days). The most popular of all Bush Limas. Pods 5 inches long crowded with 4 to 5 very thick beans of excellent quality. The stiffly erect bushes branch freely and bear tremendous crops. Plst, 10c; 1/2 1b, 35c; lb, 50c, postpaid. Not prepaid, $10 \mathrm{lbs}, \$ 3.75 ; 25 \mathrm{lbs}, \$ 8.50$.

308 Sieva Pole. (70 days). Carolina or Butter Bean. Early, hardy and productive. Pods and beans small. Pkt, $5 \mathrm{c} ; 1 / 21 \mathrm{~b}, 20 \mathrm{c} ; 1 \mathrm{~b}, 35 \mathrm{c}$, postpaid. Not prepaid, $10 \mathrm{lbs}, \$ 2.70$; $25 \mathrm{lbs}, \$ 6.25$.

309 Iarly Ieviathan Pole. (80 days). An early and productive strain of the large-seeded Pole Lima. Long pods contain 3 to 5 large beans. Pkt, 10c; $1 / 2$ lb, 25c; 1b, 40c, postpaid. Not prepaid, $10 \mathrm{lbs}, \$ 3.00 ; 25 \mathrm{lbs}, \$ 6.50$.

311. King of the Garden. (92 days). Uniformly large podded. Pods contains 4 to 5 large, flat beans. Excellent quality. Pkt, 10c; 1 1/2 1b, 25c; 1b, 40c, postpaid. INot prepaid, 10 Ibs, \$3.00; 25 ibs, $\$ 6.50$.

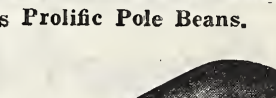
(1)

\section{西} . 


\section{Mangels or Stock Beets}

Mangels yield more tons of feed per acre than any other crop, often yielding 18 to 20 tons of roots per acre, some of the roots weighing 20 to 30 lbs. each.

They should be fed regularly to all stock. They not only increase milk production in dairy cows, but tend to promote the development of large, robust, fleshy animals that bring profit to the stockman, not only on the market, but also in the show ring. Their value really lies as much in their influence on the digestion of the animals by acting as a tonic and laxative, as on their nutriment content. In the East and in Europe Mangels are considered indispensable where stock of any kind is kept. With our long Mountain winters, the feeding of Mangels shows very profitable returns

During the Winter, when there is no green feed to be had, Mangels are a very good substitute. Chickens thrive on them, and hens lay in the Winter months when the price of eggs is high.

Mangels are one of the cheapest crops to raise. We strongly recommend every farmer to put in an acre or two this season, as we are confident the results will more than justify the outlay.

Culture-One ounce to 100 feet of row, 5 to 6 pounds per acre.

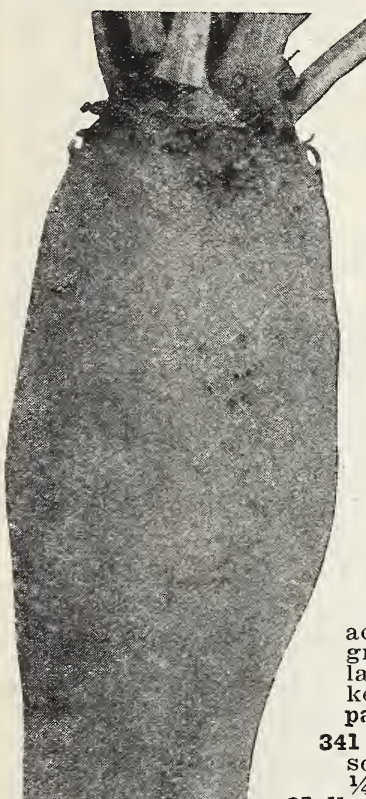

Sow in drills $21 /$ feet apart: when about three inches high, thin to 10 inches apart in the rows. Mangels do best on rich, deep loam, but can be grown on a variety of soils. Mangels are one of the best crops for Alkali soils, usually giving fair returns, and improving the ground greatly.

Mangels will stand a slight frost, but freezing will injure them and lead to rotting. At the approach of frost, cut and feed the tops. Pile the roots in a root cellar if possible. If piled outdoors, cover them with straw and about one inch of dirt. As it gets colder, put on more dirt until a cover of about 6 inches is made. Mangels may be fed whole to hogs and poultry, but should be cut for cattle.

345 Dairy Giant Mangel. (90 days). This heavy yielding Mangel has a greater food value than any other variety. Because of its heavy milk and butterfat making qualities this Mangel is especially recommended to the dairyman. Dairy Giant is a long reddish yellow variety with a small top; the flesh is white, firm and sweet. Grows half above the ground and is easily harvested. $0 z, 10 c ; 1 / 416,25 c ; 1 b, 75 c$, postpaid. Not prepaid, $10 \mathrm{lbs}, \$ 5.50 ; 25 \mathrm{lbs}, \$ 14.75 ; 100$ $1 \mathrm{~b}, \$ 49.00$.

346 Prize Mammoth Mangel. (100 days). Selected for its enormous yield, Prize Mammoth has given on good soil as high as 40 tons per acre. It is one of the easiest varieties to harvest as it grows two-thirds of the root above the ground. The large red roots are free from coarseness and excellent keepers. Oz, 10c; 1/4 1b, 25c; 1b, 70c, postpaid. Not prepaid, $10 \mathrm{lbs}, \$ 5.50 ; 25 \mathrm{lbs}, \$ 14.75 ; 100 \mathrm{lbs}, \$ 49.00$.

341 Golden Tankard. (100 days). Does well on shallow soils; a medium sized variety of excellent quality. $\mathbf{O z}, 5 \mathrm{c}$ $25 \mathrm{lbs}, \$ 11.00 ; 100$ lbs, $\$ 42.00$.

340 Giant Eckendorf. (105 days). Good on shallow soils, growing almost on top of the ground. Fair size and good quality. Oz, 5c; $1 / 4$ 1b, 15c; 1b, 50c, postpaid Not prepaid, 10 lbs, $\$ 4.50 ; 25$ lbs, $\$ 11.00 ; 100 \mathrm{lbs}, \$ 42.00$.

339 Danish Sludstrup. (110 days). The Danish Government's choice for quality, and a good yielder. Oz, 5c;1/4 1b, 15c; 1b, 50c, postpaid. Not prepaid, 10 1bs, $\$ 4.50 ; 251 \mathrm{bs}$. $\$ 11.00 ; 100 \mathrm{lbs}, \$ 42.00$.

342 Iong Red. (120 days). Produces immense crops; fiesh white, shaded red. Oz, 10c; $1 / 41 \mathrm{~b}, 20 \mathrm{c} ; 1 \mathrm{~b}, 55 \mathrm{c}$, postpaid. Not prepaid, 10 Ibs, \$5.00; 25 lbs, \$11.75; 100 lbs, \$45.00.

Dairy

Giant
Mangel.

344 Giant Half Sugar Mangel. (100 days). Combines the size of the Mangel with the great food value of the Sugar Beet. Oz, 5c; $1 / 4$ 1b, 15c; 1b, 45c, postpaid. Not prepaid

\section{For Making Sugar, or Feeding}

347 Inlein Wanzleben Sugar Beet. (75 days). Extensively grown for sugar factories, having the highest sugar content A good home made syrup can be made by slicing and boiling down these beets. This variety is the finest Winter feed for sheep. Comparatively small and can be grown 5 inches apart in the rows. Oz, 10c; 1/4 1b, 20c; 1b, 45c, postpaid Not prepaid, $10 \mathrm{lbs}, \$ 3.35$; $25 \mathrm{lbs}, \$ 7.85 ; 100 \mathrm{lbs}$, $\$ 29.50$.

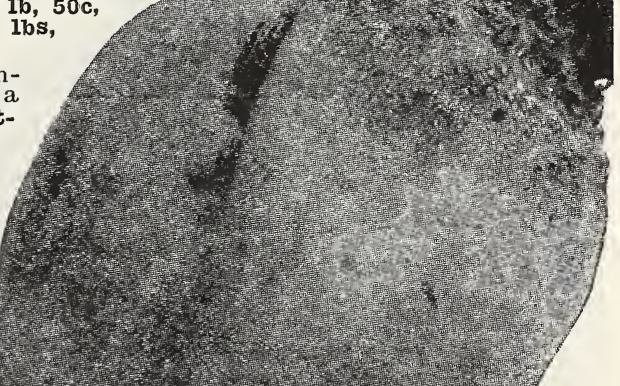

Prize Mammoth Mangel.

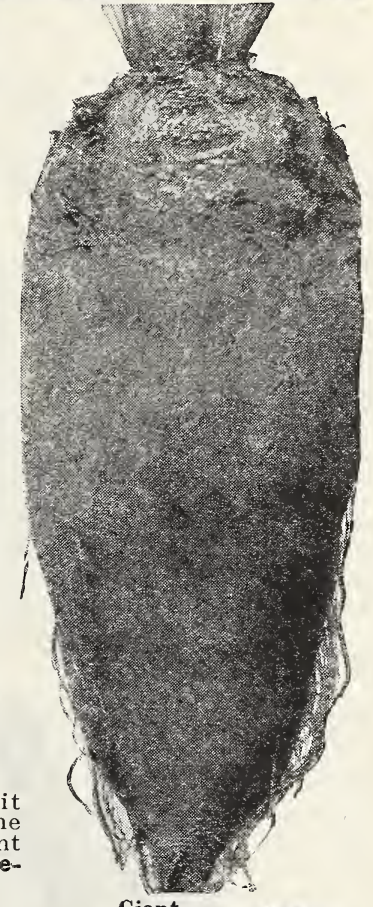

Giant Half-Suga Mangel. 


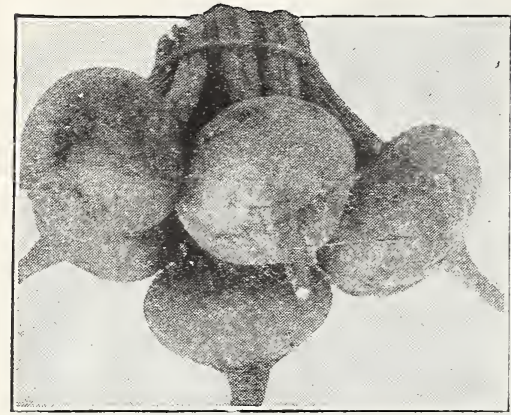

Extra Eariy Egyptian.

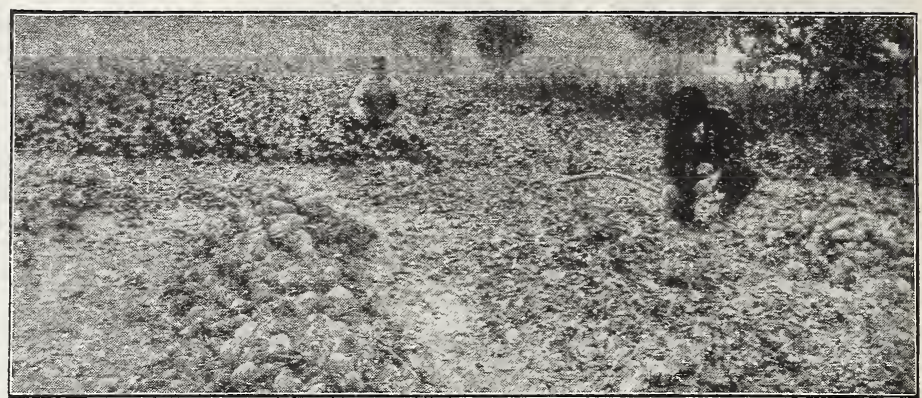

Selecting Beets for Seed.

\section{Garden Beets}

Beets are one of the easiest crops to grow and at the same time among the finest vegetables. They may be cooked and sliced for salads; buttered Beets are delicious; and a few jars of pickled Beets will be a treat in the Winter. Beets are not only tasty but health-giving, containing mineral salts, chlorine, sodiuns and iron.

Beets are a valuable crop for the commercial gardener, shipper and canner. Our Market Gardeners* Strain of Crosby's Egyptian, our Early Wonder and our Canner's Favorite are specially bred up strains, recommended not only to the commercial grower but also to the home gardener who likes his garden just a little better. We do not offer any imported Beet seed, it is now recognized that American strains of Beets are much more carefully bred than European strains.

Culture. One ounce to 50 feet of drill; 5 to $71 \mathrm{bs}$. per acre.

To get the greatest pleasure out of Beets they should be used while quite young. To have a constant supply of always tender young Beets in your home garden. sow a 15-foot row every week or two, from as early in the Spring as the ground can be worked until the middle of July.

Beets may be readily grown in any soil, but the finest Beets are grown in a deep, rich loam. Sow in

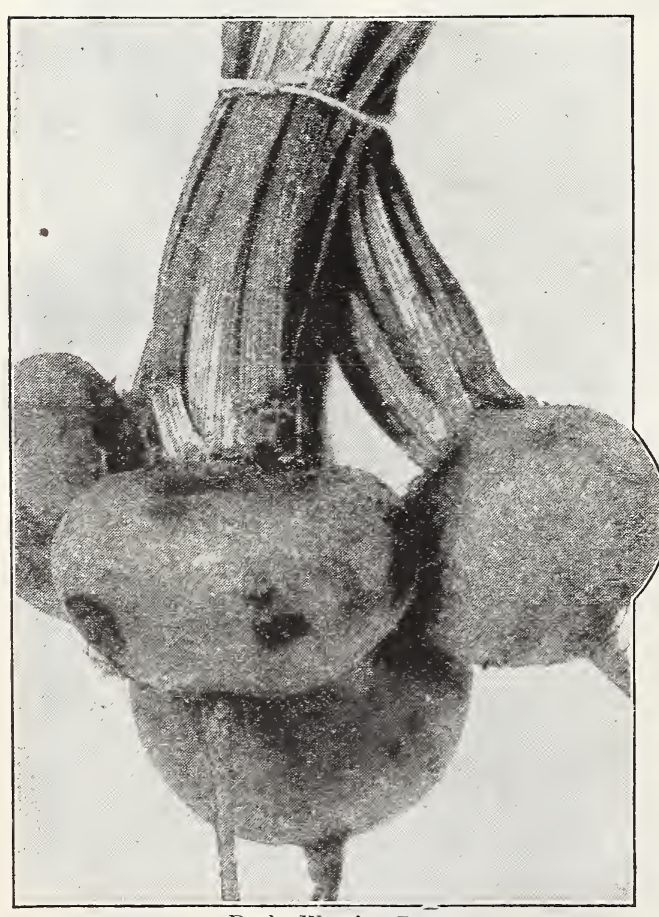

Early Wonder Beets. rows 18 to 24 inches apart cover the seed with about une-half inch of soil and firm the soil around the seed by walking along the rows. When the Beets are about 4 inches high thin them to 3 or 4 inches apart. In thinning the young plants are usually used for greens. Both top and small root are cooked together. and with a little seasoning, they are delicious.

For Winter use, make a large sowing in midsummer. Before frost, harvest and pack them in sand in the cellar and you will have fresh Beets far into the winter. In harvesting do not cut the tops too close.

327 Detroit Dark Red. days). Roots round and medium size, good deep red color. An old time standard for home gardens, market or canners. Plt, 5c; oz, 15c; $1 / 41 \mathrm{~b}, 35 \mathrm{c}$; 1b, \$1.00, postpaid. Not prepaid, 5 lbs, $\$ 4.25 ; 25$ 1bs, $\$ 17.00$.

330 Extra Farly Egyptian. (42 days). One of the eariliest Beets. The color of the flesh is a dark purplish red zoned with a lighter red shade. foots are tom ends. Small tap root and sparse foliage make this variety suitable for forcing. Plkt, 5c; cz, 15c; $1 / 41 \mathrm{~b}, 35 \mathrm{c} ; 1 \mathrm{~b}, \$ 1.00$, postpaid. Not prepaid, $5 \mathrm{lbs}, \$ 4.25 ; 251 \mathrm{bs}, \$ 17.00$.

334 Canner's Eavorite. (55 days). Round, dark red, ideal for canning. The result of several years' selection from the Detroit Dark Red. This is the very finest variety for canning. The roots are a deep globe shape very smooth and uniform. The color is a true dark red, showing, only slightly, zones of a lighter red shade. The flesh is tender and decidedly sweet, without any trace of woodiness or stringiness. While primarily a canning variety, Canner's Favorite is excellent for the main crop in your garden. The rich dark red color makes an attractive dish on your table. Plat, 10c; 0z, 25c; 1/4 1b, 70c; 1b, \$2.00, postpaid. Not prepaid, 5 lbs, $\$ 7.75 ; 25$ lbs, $\$ 31.00$.

324 Early Wonder or Farly Model. (45 days). A fine selection from Crosby's Egyptian, being a little smaller in size. Average more full at the bottom and come a little earlier. The demand for Early. Wonder is growing each year. It is a turnip-shaped variety of very uniform type and is always smooth. Flesh is a beautiful deep red color, more unifolm than Crosby, and is of excellent quality. Tops are small and erect and it may, therefore, be planted closer than most other sorts, thereby increasing the yield. Pkt, 5c; oz, 15c; 1/4 1b, 35c; 1b, \$1.00, postpaid. Not prepaid, 5 ibs, $\$ 4.25$; 25 Ibs, $\$ 17.00$.

Gentlemen:-Your seeds are fine. Your Canner's Favorite Beets are the best I ever ate and they are also the most beautiful color I have ever seen. I took first premium on them last Fall at our Lewis County Fair. They showed up the finest of any there on display. And there was sure a large display from the garden district down on the Clearwater River.

\section{Very truly yours,}




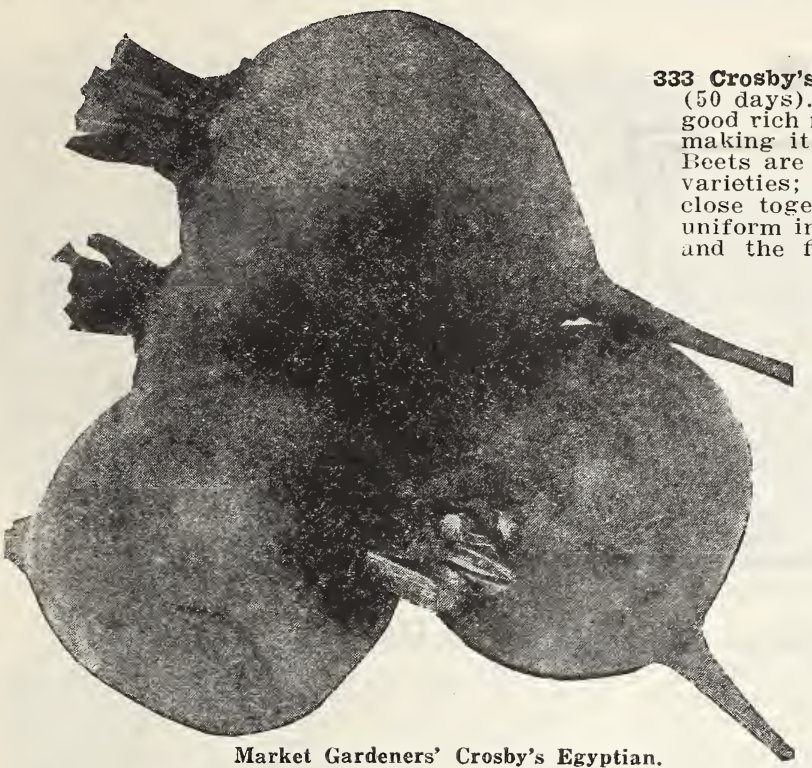

BEETS-Continued.

Crosby's Fgyptian (Special Market Gardener's Strain). days). Very early, good size, fine deep turnip shape, good rich red color. "Takes on its turnip shape very early. making it an excellent market variety, especially where sold in bunches. One of the heaviest yieldin' rows. The special strain is very uniform in both shape and color. The skin is a dark red and the flesh slightly lighter in color. Shows a fine bright red color when cooked and has an ex$1 \mathrm{~b}, \$ 1.25$, postpaid. Not prepaid, 5 1bs, $\$ 5.50$; $25 \mathrm{lbs}, \$ 23.50$.

326 Crosby's Egyptian. (50 days). Probably the most widely used of all varieties of Beets. Early, good size and good yield. A favored variety both for home garden and shipping. Pkt, 5c; oz, 15c; 1/4 1b, 35c; 1b, $\$ 1.00$, postpaid. Not prepaid, $5 \mathrm{lbs}, \$ 4.25 ; 25$ Ibs, $\$ 17.00$.

329 Idmand's Blood Turnip. (65 days). A second early variety and quite uniform in type. It may be kept in perfect condition throughout the Winter. Tops are small and erect, allowing close growing and a large vield. Pkt, 10c; oz, 20c; $1 / 41 \mathrm{~b}, 35 \mathrm{c} ; 1 \mathrm{~b}, \$ 1.00$, postpaid. Not prepaid, 5 lbs, \$4.25; 25 lbs, $\$ 17.00$.

331 Early Eclipse. (50 days). An old favorite; smooth bright red roots, round or slightly top-shaped. The flesh is bright red, zoned with pink. Very sweet, crisp and tender when young. Prt, 5c; oz, 15c; 1/4 1b, 35c; lb, \$1.00, postpaid. Not prepaid, 5 1bs, \$4.25; 25 lbs, $\$ 17.00$.

328 Improved Early Blood Turnip. (65 days). A medium early variety good for Summer or Winter use. Roots grow to a good marketable size; flesh is deep red and of good quality. Plkt, $5 \mathrm{c} ;$ oz, 15c; $1 / 41 \mathrm{~b}, 35 \mathrm{c}$; 1b, $\$ 1.00$, postpaid. Not prepaid, 5 lbs, $\$ 4.25 ; 25$ lbs, $\$ 17.00$.

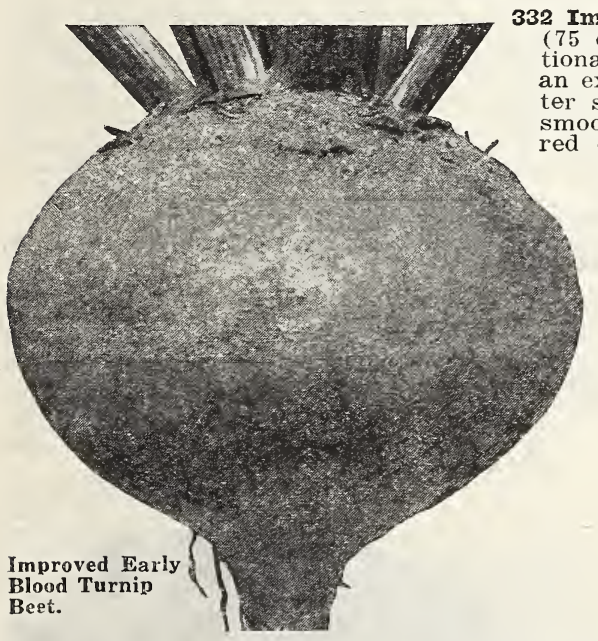

mproved Half-Irong Blood. 75 days). Grows to exceptional size on good deep soil, n excellent variety for WinRoots are long, ooth and uniform, blackish $1 / 30$, $30,90 c$, post paid. Not prepaid, 5 1bs, \$4.00; 25 1bs, \$15.50.

\section{Crosby's Egyptian. \\ Swiss Chard \\ (Spinach Beet)}

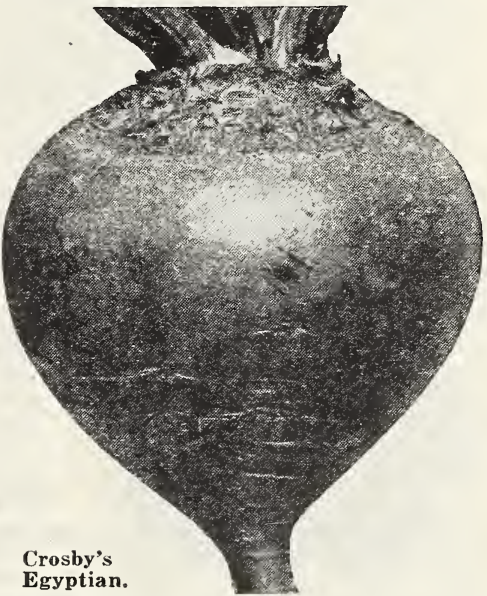

Keep Fit-Eat Plenty of Swiss Chard.

An easily grown Beet which forms no roots, but makes big tops. After once having used Swiss Chard for greens, we believe your garden will always have at least a row, for the fleshy leaves are so tender and delicious. Not only are the leaves an excellent substitute for spinach, but the large white ribs may be boiled and creamed like asparagus. Swiss Chard is a very hardy plant, it may be sown early and will yield until late Fall.

One ounce to 100 feet of drill; 4 lbs. per acre.

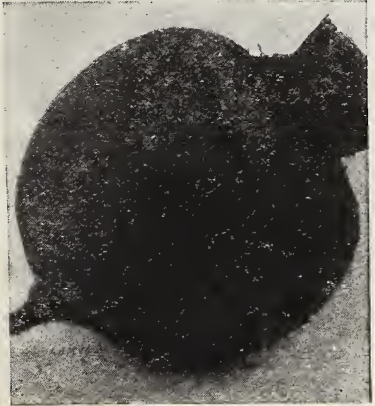

Fdmand's Blood Turnip Beet.
336 Iarge Ribbed white. Large, smooth leaves with silvery white stems; tender and fine flavor. Pkt, 5c: oz, 10c; 1/4 1b, 30c; 1b, 90c, postpaid. Not prepaid, 5. Ibs, $\$ 4.00$.

337 Giant Iucullus. A new savoyed leaf sort, with very large leaves. Tall growth, extra fine quality. Pikt, 10c; oz, 20c; 1/4 1b, 35c; 1b, $\$ 1.00$, postpaid. Not prepaid, 5 lbs, \$4.25.

Gay, Sulivan \& Co., Inc., Sales Agents,

New Orleans, Louisiana.

Gentlemen:-Replying to your inquiry dated December 7 th, we are pleased to state that all seeds which we purchased from Grand Junction Seed Company have made a great hit among our farmers, accordingly we would not consider buying seeds elsewhere as long as the Grand Junction Seed Company can supply us.
Very truly yours,
CHAS. MUMPHREY. New Orleans, La.

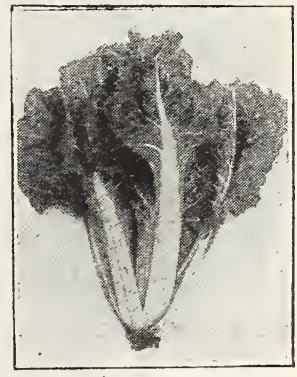

Large Ribbed White Swiss Chard. 


\section{Choice Cabbage}

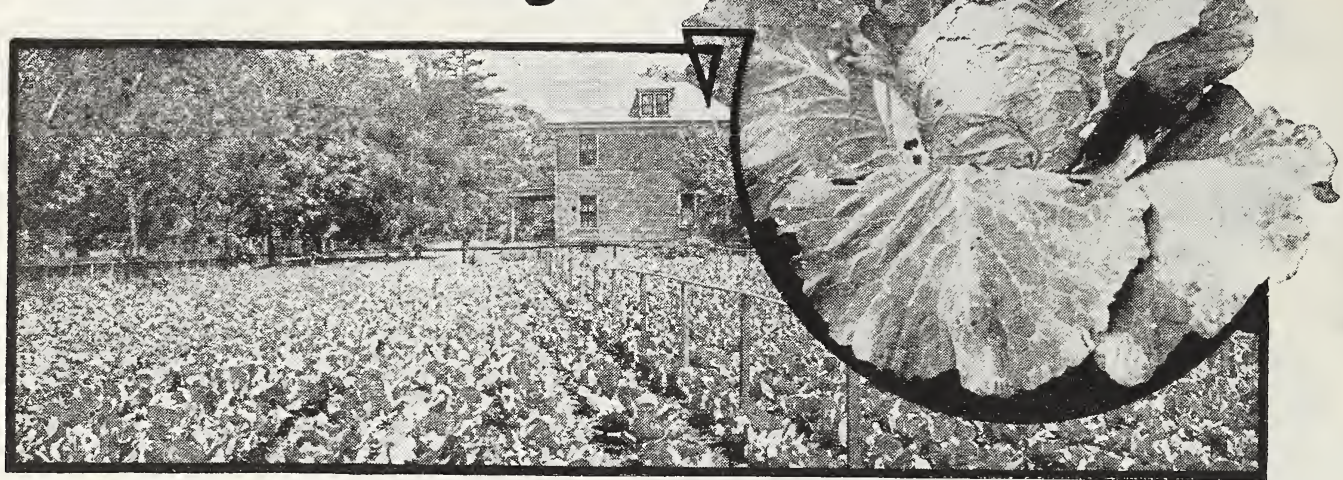

Field of Charleston Wakefield Cabbage.

\section{American Cabbage Seed Now the Best}

Before the war, European Cabbage seed was used almost exclusively for planting in this country. During the war, with the European supply cut off, American growers began to grow Cabbage seed and they found they could grow even better seed than the European growers. Today the better class of American growers are producing an excellent quality of seed.

We supply some of the largest growers in the shipping sections with their Cabbage seed, so you can be assured that the quality of our Cabbage seed is the finest obtainable. "Don't forget that cheap seed is usually the most expensive in the long run."

Culture. One ounce produces 2000 plants; 4 to 6 ounces per acre. For early crop sow seed in hotbed in early Spring, transplant once before setting out. For Winter use sow in beds outside about June 1st. In

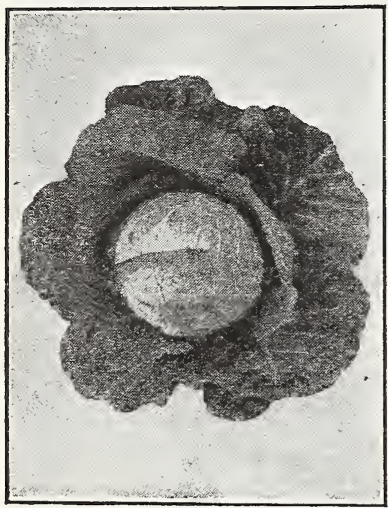

Copenhagen Market Cabbage. transplanting one-third of the upper portion of leaves should be cut off to transplanting one-third of the upper portion of leaves should be cut off to
prevent too rapid evaporation of water through leaves. Plants should be set in rows $21 / 2$ feet apart, plants 15 to 30 inches apart in rows. Give the crop shallow cultivation as frequently as possible. For Winter use, remove stems and outer leaves, and store the Cabbage heads in a cool cellar. To store in outdoor pits, set entire plants closely in a shallow trench and cover with straw and soil.

366 Earliest of All. (75 days). The earliest round head Cabbage, earlier than Early Jersey Wakefield and two weeks earlier than any of the old standard round head varieties. Solid heads are smaller than Copenhagen Market and just right for family use. The quality is fully equal to Copenhagen Market. The outer leaves are smaller, allowing of closer planting. In our trial plots almost every plant has produced a head, solid as lead and did not burst. We certainly recommend Earliest of All to the home gardener and the market gardener. Plkt, 15c; $1 / 2$ oz, 45c; oz, 65c; $1 / 41 \mathrm{~b}, \$ 1.90 ; 1 \mathrm{~b}, \$ 6.00$, postpaid. INot prepaid, $5 \mathrm{lbs}, \$ 25.00$.

365 Golden Acre. ( 80 days). Our strain of Earliest of All is a finer selection of this standard variety. Pkt, $10 \mathrm{c} ; 1 / 2$ oz, 35c; oz, 60c; $1 / 41 \mathrm{~b}, \$ 1.75 ; 1 \mathrm{~b}, \$ 5.50$, postpaid. Not prepaid, $5 \mathrm{lbs}, \$ 20.00$.

352 Copenhagen Market. (90 days). Large, solid, round heads of a perfectly even type. A variety of real value to the shipper and market gardener. Widely used in the higher mountain sections where it produces heads of exceptionally large size. Each plant forms a perfect, tightly folded head with a small core. Practically as early as the pointed Early Jersey Wakefield and a much heavier yielder. Extra selected market gardener's stock. Plrt, 10c; 1/2 0z, 25c; oz, 40c; 1/4 1b, \$1.15; lb, $\$ 3.50$, postpaid. Irot prepaid, 5 ibs,

355 Glory of Fnkhuizen. (100 days). A very heavy yielding variety, similar in many wavs to Copenhagen Market, but a larger Cabbage and a little later. In our trial ground tests we have found Glory to be the solidest, tenderest and finest flavor of all early Cabbages. A sure header and a splendid keeper. Remarkably uniform as to type and size. Pkt, 10c; $1 / 2$ oz, 25c; 0z, 40c; $1 / 41 \mathrm{~b}, \$ 1.15 ; 1 \mathrm{~b}, \$ 3.50$, postpaid. sot prepaid, 5 lbs, $\$ 14.00$.

358 Stein's Early Flat Dutch. (100 days). Excellent secondearly variety, producing fine large heads. Highly valued for its fine quality and ability to resist heat. Heads are round, flattened on top, measure 13 inches across and weigh from 10 to 12 pounds each. A favorite kind with many market growers. A dependable variety and very productive. Pkt, 5c; $1 / 2$ oz, 20c; oz, 30c; $1 / 41 \mathrm{~b}, 80 \mathrm{c}$; 1b, $\$ 2.25$, postpaid. ITot prepaid, 5 lbs, $\$ 9.00$.

364 Succession. As the name indicates it does not all head up at once, making it well suited to home gardens. Will stand hot sun and dry weather better than most varieties. Heads large and somewhat flattened. Plrt, 10c; 1/2 oz, 25c; oz, 35c ; $1 / 4 \mathrm{Ib}, 80 \mathrm{c} ; \mathrm{lb}, \$ 2.25$, postpaid. Not prepaid, $5 \mathrm{lbs}, \$ 9.00$.

361 All Fead Faxly. (105 days). One of the earliest large Cabbages. A flat Dutch type of compact growth and heavy yield. Larger than Stein's Flat Dutch and a little later. Remarkably uniform size and shape. Pkt, 10c; $1 / 2$ oz, 25c; oz, 35c; $1 / 4$ Ib, 85c; 1b, $\$ 2.25$, postpaid. iNot prepaid, 5 1bs, $\$ 9.00$.

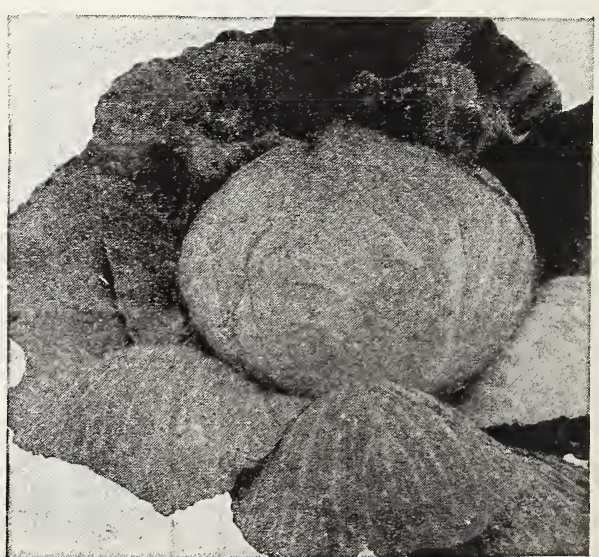

Glory of Enkhuizen Cabbage. 


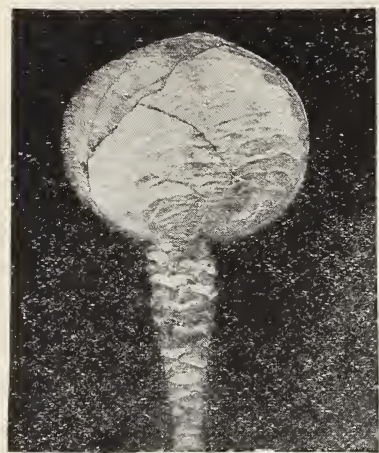

Hollander Cabbage.

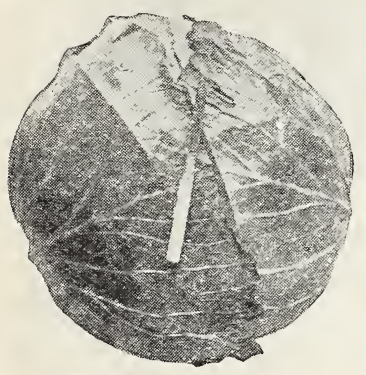

Mountain Fallhead.

\section{CABBAGE-Continued.}

356 Farly Jersey Wakefield. ( 80 days). Dwarf, compact plants maturing very early. The heads are pyramidal in shape, having a blunted or rounded peak. Very sweet flavor. Small outside foliage and a uniform crop. Pkt, 10c; $1 / 2$ oz, 25c; oz, 35c; $1 / 41 b, 85 c ; 1 b, \$ 2.25$, postpaid. Not prepaid, 5 1bs, $\$ 9.00$.

357 Farly Winnigstadt. (85 days). Heads same size as Early Jersey Wakefield but more sharply pointed. The leaves are dark green, slightly glossy and the heads are the hardest of any early Cabbage. Pkt, 10c; oz, 30c; $1 / 4 \mathrm{lb}, 80 \mathrm{c} ; 1 \mathrm{~b}, \$ 2.25$, postpaid. INot prepaia, 5 lbs, $\$ 9.00$.

359 Charleston or Inarge Wakefield. (85 days). A selection from Early Jersey Wakefield, producing a larger and more solid head. Charleston Wakefield is more uniform in type and a much better shipping variety. A heavy yielder and of fine quality. Pkt, 10c; oz, 30c; $1 / 41 \mathrm{~b}, 90 \mathrm{c} ; 1 \mathrm{~b}$, $\$ 2.50$, postpaid. Not prepaid, 5 lbs, $\$ 10.50$.

371 surehead. (120 days). A sure header of the flat Dutch type. Heads very large and extra solid. Pkt, 10c; $0 \mathrm{z}, 30 \mathrm{c} ; 1 / 42 \mathrm{~b}, 90 \mathrm{c} ; 1 \mathrm{~b}, \$ 2.75$, postpaid. Not prepaid, 5 los, $\$ 12.00$.

372 Inarge Irate Drumhead. (130 days). All excellent Winter keeping variety. Heads large, solid, flat but very deep. Pkt, 10c; $1 / 2$ oz, 25c; oz, 35c; $1 / 41 b$, \$1.10; 16 ; $\$ 3.25$, postpaid. Irot prepaid, 5 lbs, $\$ 14.00$.

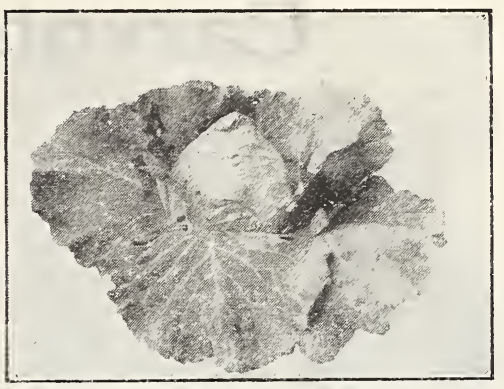

Lariy Jersey IVakefield.

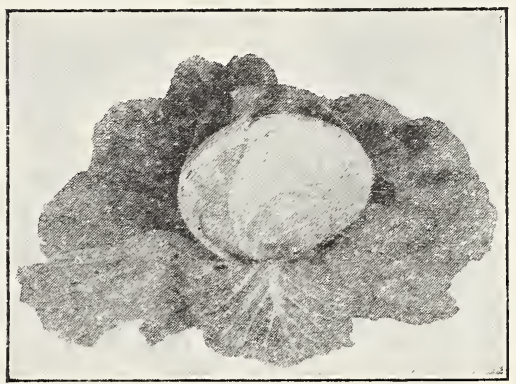

Ail Head Early.

370 Premium Irate Flat Dutch. (150 days). Heads are large, very solíd and compact. A heavy yielder and fine keeper. Pkt, 10c; oz, 30c; 1/4 1b, 80c; 1b, $\$ 2.45$, postpaid. Not prepaid, $5 \mathrm{lbs}, \$ 10.25$.

373 Mountain Ballhead, Short Stem. (140 days). The secret of the increased tonnage of this strain lies in the selection for hard, tight heads which weigh one-third more than ordinary heads of equal size. It has unusual keeping qualities, due partly to an unusual lap-over of the leaf, a very desirable feature for late storage. This is our finest variety for Winter storage. Pkt, $10 \mathrm{c} ; 1 / 2$ oz, 30c; oz, 45c; $1 / 4$ 10, $\$ 1.60$; ib, $\$ 5.00$, postpaid. Irot prepaid, 5 1bs, $\$ 23.00$.

368 Danish Round Head, Short Stem. (150 days). Produces large, ball-shaped heads of great solidity. Desirable because of its intensely deep color. Excellent keeper. Pkt, 10c; oz, 45c; 1/4 1b, \$1.35; 1b, $\$ 4.10$, postpaid. Not prepaid, 5 1bs, \$17.00.

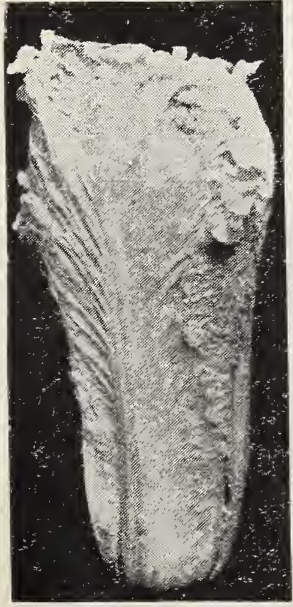

Wong Bok

Chinese Cabbago.

\section{Chinese Cabbage}

Also known as Celery Cabbrage has a fine delicate flavor, as tender as head lettuce. In great demand for numerous dishes, such as salads and cold slaw, or it may be cooked quickly. It cannot be grown successfully as a Spring crop where the Summers are hot. For a fine Fall crop, sow early in August.

376 wong Bok. The heads of this variety are short and heavy. It has beautifully curled leaves of fine quality and is a sure header. Pkt, 10c; 1/2 oz, $20 \mathrm{c} ; 0 \mathrm{O}, 30 \mathrm{c} ; 1 / 4 \mathrm{lb}, 90 \mathrm{c} ; 1 \mathrm{~b}$, $\$ 2.70$, postpaid.
369 Flollander or Danish Ballhead. (160 days). A strain which we have been offering for a number of years and which has given the finest satisfaction to mountain Cabbage shippers. This is the finest strain of the tall or medium stem Ballhead obtainable. Eall-shaped heads are exceptionally heavy and never burst. It is sweet, crisp and tender in flavor. Adapts itself readily and grows well on all soils. Plxt. 10c; oz, 35c; 1/4 1b, \$1.00; $1 \mathrm{~b}, \$ 3.00$, postpaid. Not prepaid, 5 lbs, $\$ 13.25$.

377 Perfection Drumhead Savoy. (120 days). The heavily curled, crimped and savoyed leaves and dark green heads, which are uniformly well formed and solid, will give this Cabbage first consideration on any market. Flavor improved by frost. Pkt, 10c; oz, 30c; 1/4 1b, 90c; 1b, \$2.75, postpaid. Not prepaid, 5 lbs, $\$ 11.75$.

374 Mammoth Red Rock. (130 days). Heads grow as large as Premium Flat Dutch. Hard, solid heads are a fine rich, deep red color to the center. Pkt, 10c; $1 / 2$ oz, 25c; oz, 40c; $1 / 41 \mathrm{~b}, \$ 1.20 ; 1 \mathrm{~b}, \$ 3.75$; postpaid. Not prepaid, $5 \mathrm{lbs}, \$ 15.25$.

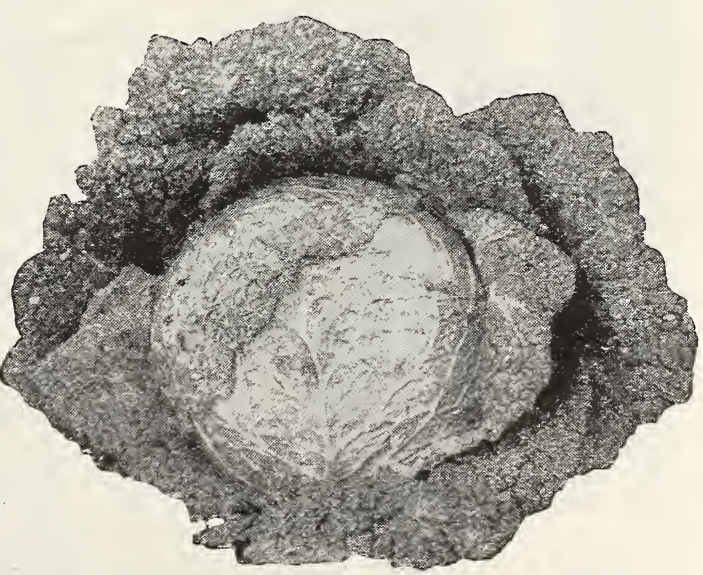

Perfection Drumhead Savoy. 


\section{Carrots}

Carrots are not alone one of the most wholesome of foods, supplying precious vitamins, but when half grown are one of the greatest delicacies possible to place on the

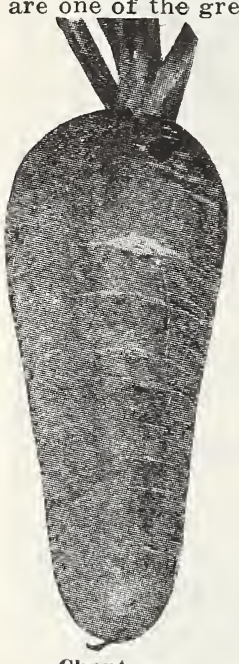

Chantenuy.

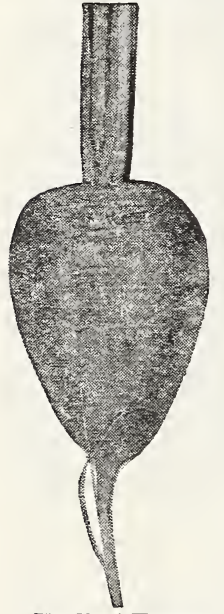

Earliest French rorcing.

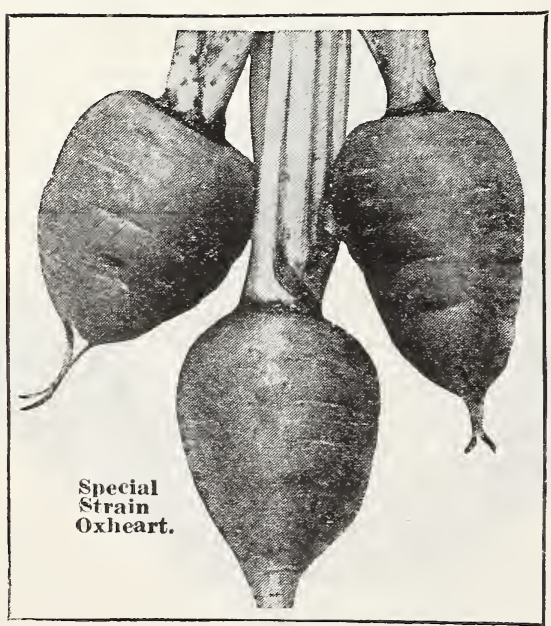
seed. customers. table. Carrots are so easy to grow, may be used in so many ways, and keep so well in the cellar during the Winter that every home garden should have at least a few rows. As a commercial shipping crop, Carrots have brought big returns per acre. The important feature in a shipping crop is to have the Carrots an even, uniform type. Prior to 1914 the finest Carrot seed came from France, since that date the big improvements in selecting and breeding of Carrots have been made in this country. There is now a wide difference in American and European Carrot seed. We do not offer any European Carrot

The important shipping varieties of Carrots are grown on our own farms, the roots are carefully sorted and selected each year to maintain an even and close-to-perfect type. Any roots even slightly off-type are sold to the grocery trade and only the perfect Carrots planted for seed. The picture on the front cover shows one of our Carrot seed fields in bloom. The arduous, but most necessary, work of careful root selection has been done and the crop is almost ready to harvest and distribute to our

Culture. One ounce to 200 feet of row; 4 to 6 pounds per acre. Any

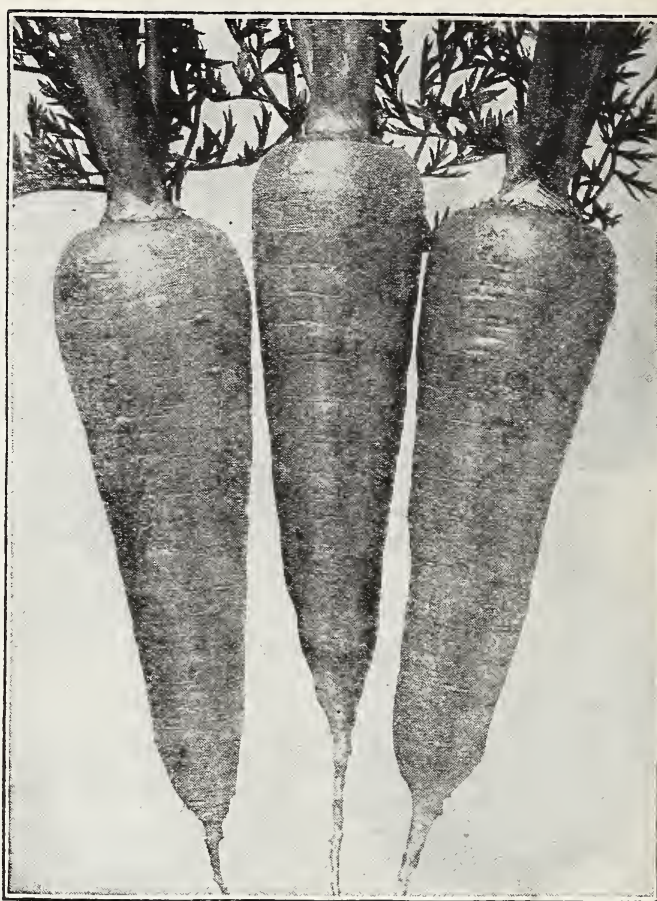

Danvers Haif-Long Carrots. grown and perfect roots develop only in rich, loose soil, preferably sandy loam, or even clear sand when well fertilized and kept moist. In rich, loose soil no thinning is necessary except for the purpose of getting large, perfectly formed Carrots. Tonnage, represented by a large product, is produced by planting thick, keeping the weeds out and the land cultivated, well drained, moist but not too wet. The flavor and tenderness of table varieties is secured by quick, unchecked growth. In hot weather a light covering of straw will assist germination; the straw must be removed when the sprouts begin to appear. For Winter use store Carrots in slightly moist sand or sandy soil in a root cellar.

380 Earliest French Forcing. (45 days). The earliest variety, roots are almost globular when forced, but slightly longer when grown outdoors. The tops are quite small, allowing of close planting. The color is orange-scarlet and a trifle lighter than most other orange-scarlet varieties. Extra fine quality Carrots average $1 \frac{1 / 2}{2}$ inches in diameter. Pkt, 10c; 0z, 20c; $1 / 4 \mathrm{lb}, 45 \mathrm{c} ; 1 \mathrm{~b}, \$ 1.25$, postpaid. Not prepaid, $5 \mathrm{lbs}, \$ 5.25$.

387 Special Strain Oxheart. (55 days). A special selected strain of this important variety. While the full grown Carrot is very stump-rooted, when young the bottom is not flat and even promises to be pointed rooted. The roots take on a desirable shape when quite young and are excellent for early bunch Carrots. Oxheart is a heavy cropper having a large amount of edible flesh to the root. Full grown roots are 51/2 to 6 inches long, $3 \frac{1 / 2}{2}$ inches thick at the top and 2 inches thick at the bottom. The color is a bright orangescarlet. Being short and nearly globular, the Carrots can be easily harvested. The core is rather large and if grown with too much moisture this variety will split. Plit, 10c; oz, 20c; 1/4 Ib, 45c; 1b, \$1.10, postpaid. Not prepaid, $5 \mathrm{lbs}, \$ 4.50 ; 25 \mathrm{lbs}, \$ 17.75$.

382 Oxheart or Guerande. (55 days). Pkt, 5c; oz, 10c; 1/4 1b, 30c; 1b, 95c, postpaid. Not prepaia, $5 \mathrm{lbs}, \$ 4.00$; $25 \mathrm{lbs}, \$ 15.75$.

388 Improved Chantenay. (60 days). Illustrated in color on the front cover. This improved type was developed mainly for canning. The core, which was rather large and definite, has been made smaller, a darker color and more tender, so that the core is not now noticeable. The whole color of the improved type is darker, being a deep orange-scarlet. Chantenay is a shapely variety, fine appearance and excellent quality. In size between the Oxheart and Danvers, full grown roots are $51 / 2$ inches long, $2 \frac{1}{2}$ inches thick at the crown and $11 / 2$ inches thick at the bottom, half long and very stump-rooted. The top is small and set in a slight depression. Plst, $10 \mathrm{c} ;$ oz, 20c; $1 / 41 \mathrm{~b}, 55 \mathrm{c}$; Ib, \$1.65, postpaid. Not prepaid, 5 lbs, $\$ 6.50 ; 25$ Ibs, $\$ 26.00$.

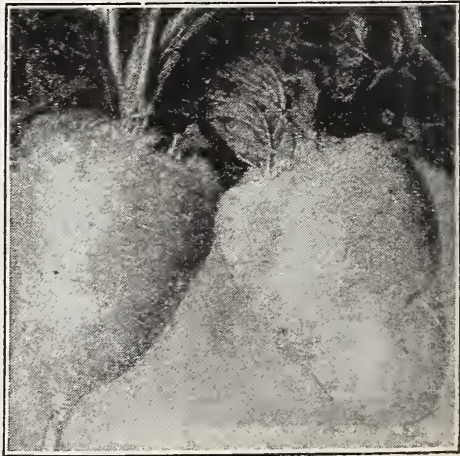

Oxheart or Guerande. 


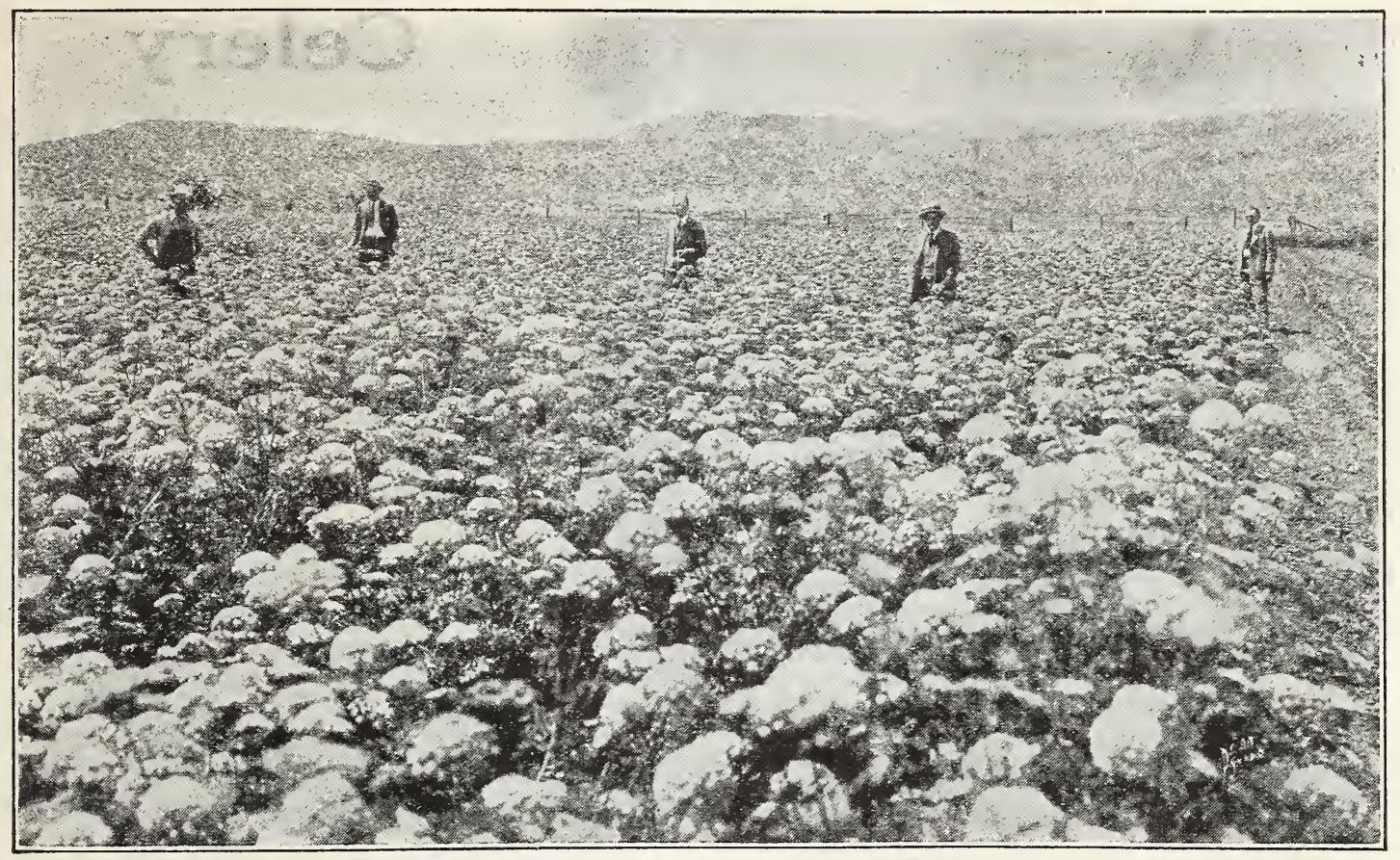

Growing "Mile High" Carrot Seed-Field in Full Bloom.

CARROTS-Continued.

383 Chantenay or Falf Iong Model. (60 days). Similar to Improved Chantenay but the color is a bright orange-scarlet and the core rather large and definite. Pkt, 5c; oz, 10c; 1/4 1b, 30c; 1b, 95c, postpaid. Not prepaid, 5 Ibs, $\$ 4.25$; 25 Ibs, $\$ 20.00$.

384 Danvers Half Iong. (65 days). The heaviest yielding half-long variety. One of the best for general crop and a profitable variety for market gardeners. Danvers is productive in all classes of soil. Full grown Carrots are semi-pointed, $7 \frac{1}{2}$ inches long, $2 \frac{1 / 2}{2}$ inches thick at the crown and $3 / 4$ inch thick at the bottom, just where the root begins to taper to the tip. The quality is fine, the color is a bright orange-scarlet and the core is rather definite. The tops are a little larger than Chantenay. While of table quality, the heavy yield also makes Danvers suitable for a stock Carrot. Plat, 10c; 0z, 20c; 1/4 1b, 40c; ib, $\$ 1.20$, postpaid. Not prepaid, $51 \mathrm{bs}, \$ 5.25 ; 25 \mathrm{lbs}, \$ 24.75$.

379 Coreless. (55 days). The most delicately flavored Carrot grown. The color is bright orange-red, core almost the same Full grown Carrots are $41 / 2$ inches long, about 1 inch thick and cylindrical. Small, short

tops. This variety is listed by very few louses as it vields a very small quantity of seed.

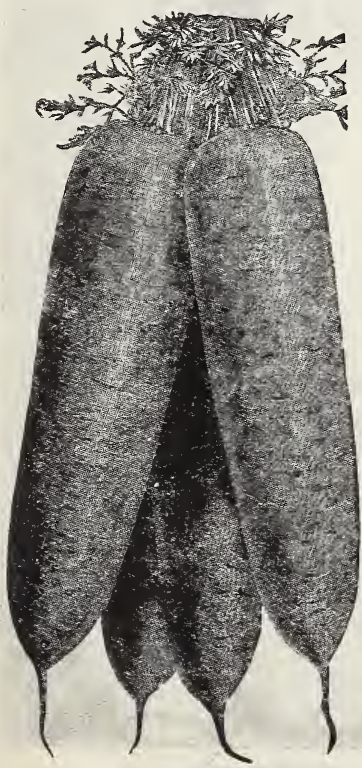
$5 \mathrm{lbs}, \$ 8.25$.

385 Nantes. (60 days). Larger than "Coreless" and nearly as good in quality. Often called coreless as the core is rather undefined. Color is pure orange-scarlet. Full grown roots are 7 inches long and $11 / 2$ inches thick, cylindrical in shape and quite smooth. Tops small. Nantes is rather sensitive to weather changes. Pkt, 5c; oz, 15c; 1/4 Ib, 35c; 1b, \$1.00, postpaid. Not prepaid, $5 \mathrm{lbs}, \$ 4.25 ; 25 \mathrm{lbs}, \$ 17.50$.

392 Red st. valery. ( 80 days). A heavy yielder, bright orangescarlet fiesh and rather large core, large tops. Length 10 inches, $21 / 2$ inches thick at shoulder, tapers to a point. Plkt, $5 \mathrm{c}$; oz, 15c; 1/4 1b, 35c; 1b, $\$ 1.10$, postpaid. Not prepaid, $5 \mathrm{lbs}$, $\$ 4.80 ; 25 \mathrm{lbs}, \$ 19.00$.

389 Iarge white Belgian. (85 days). A heavy yielding stock Carrot our strain grows wholly underground and is white to the crown Length 12 inches or more, 2 inches thick at shoulder, long and pointed. $\mathrm{Oz}, 10 \mathrm{c} ; 1 / 4 \mathrm{lb}, 25 \mathrm{c}$; 1b, 75c, postpaid. Wot prepaid, 5 lbs., $\$ 2.80 ; 25$ ibs., \$12.75.

\section{Planet Jr. Garden Implements Prices not prepaid.}

Tro 4. Combined Hill and Drill Seeder, Single Wheel . Culter Weight 50 lbs. \$18.00.

No. 3. Hill and Drill Seeder. For the commercial vegetable grower, excellent for onion planting. Weight $49 \mathrm{lbs}$. $\$ 17.50$.

No. Double and single wheel Hoe and Cultivator. Weight 32 lbs. $\$ 10.75$.

No. 13. Double and single wheel Hoe. Weight $27 \mathrm{lbs}$. $\$ \mathbf{8 8 . 0 0}$.

No. 18. Single wheel Hoe. Weight 17 lbs. $\$ 5.75$

Nantes Carrots.

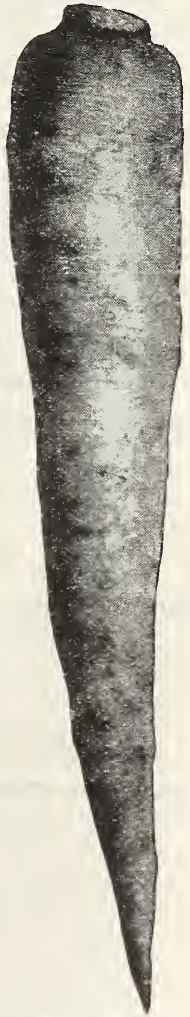

Large White Belgian. 


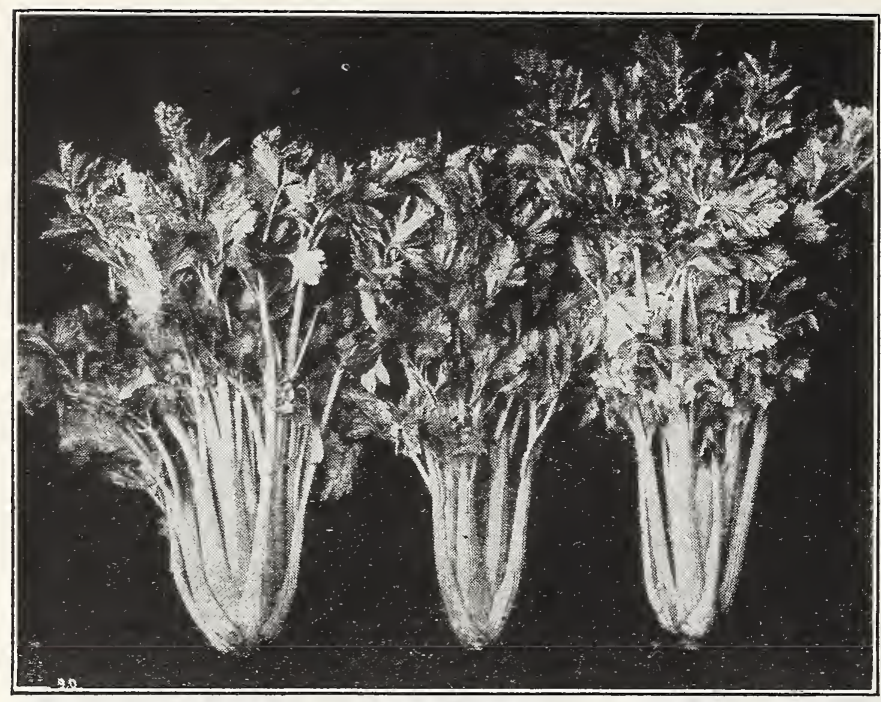

Golden
Plume.
Dwarf Golden Extra Early Tall Self Blanching. Golden Self Blanching.

\section{Celery}

For Celery Plants see page 48.

Celery is easy to grow, any soil light and rich enough to grow good Lettuce and Cabbage will grow good Celery. As with these crops a cool climate produces the best and Celery is fast becoming one of the most important commercial vegetable crops of the West. All of the western states are now producing more or less Celery on a commercial scale, with California, Colorado, Idaho ana Utah in the lead.

The cool climate of the mountain and foothill sections produces Celery that is unequaled in quality by that from any other section of the country.

You will find listed below the varieties best adapted for commercial planting as well as for the home or farm garden.

The finest Celery seed at one time came from France, but during and since the war, the finest strains have been developed in this country. We do not offer European Celery seed.

Culture. One ounce for 3000 to 5000 plants; 4 ounces per acre.

Sow the seed in a hotbed in March for early Celery and in April for Winter Celery. Celery seed is small and slow to germinate. The seed should be covered only about a quarter of an inch with fine soil or sand. The beds should be kept moist by frequent water-
ing with a fine spray. Plants should be set in the open in May for early Celery and in late June for Winter
crop. Celery requires plenty of water and the growth of the plants should never be checked. Small crops of only about a quarter of an inch with fine soil or sand. The beds should be kept moist by frequent water-
ing with a fine spray. Plants should be set in the open in May for early Celery and in late June for Winter
crop. Celery requires plenty of water and the growth of the plants should never be checked. Small crops of crop. Celery requires plenty of water and the growth of the plants should never be checked. Smali crops of Celery for Winter storage should not be blanched in the field, but packed closely together in soil in the cellar or covered trench in the field. Keep soil around plants moist and well ventilated.

427 Golden Plume or Wonderful. (100 days). The earliest variety of Celery grown. Blanches more readily than any other Celery, in fact, it can be blanched in five days. The staiks are short and the heart is large and solid. Being more vigorous than Golden Self Blanching, it withstands heat and blight better. This Celery is a beautiful gold in color, brittle and of the highest table quality. Golden Plume is not long keeping and in shipping should be handled promptly when ready for market. Plst, 15c; $1 / 2$ 0z, 80c; oz, $\$ 1.20 ; 1 / 41 \mathrm{~b}, \$ 3.25 ; 1 \mathrm{~b}, \$ 9.50$, postpaid. 432 Extra Early Tail Golden Self Blanching. (110 days). This new strain is from 10 days to two weeks earlier than the dwarf strain, according to the locality in which it is grown. It differs from the dwarf type by making a decidedly heavier and taller growth and a larger number of leaf stalks. The foliage is also quit distinct and has been bred for disease resistance. Blanches very readily to a beautiful golden yellow color. Of marvelous table quality. This variety should be carefully tested by commercial growers to determine its adaptability to their growing conditions and their market. Pkt. 15c; $1 / 2$ oz, 70c; oz, $\$ 1.00$; 1/4 1b., $\$ 3.25$; 1b, \$9.50, postpaid.

429 Golden Self Blanching. (120 days). This is the original type, known as the Vilmorin old Type. It is of dwarf, compact growth, with thick, solid, heavily ribbed stalks which blanch easily to a clear, waxen yellow. The stalks are crisp and solid free from stringiness, and of most delicious flavor. Yields a good crop of heavy and brittle stalks. Pkt, 10c $1 / 2$ oz, 45c; oz, 65c; 1/4 1b, \$2.00; 1b, \$5.75, postpaid.

428 Easy Blanching or Sanford Superb. (125 days). The earliest of the white varieties. A remarkably easy variety to blanch, and being adapted to early use as well as storing for Winter makes it well suited both to the market gardener and the home gardener. Stalks are white, thick, brittle and of excellent flavor. A strong, healthy grower. Pkt, 10c; $1 / 2$ oz, 35c; oz, $50 \mathrm{c}$ $1 / 41 \mathrm{~b}, \$ 1.35 ; 1 \mathrm{~b}, \$ 3.75$, postpaid.

431 Giant Colorado Pascal. (140 days). When grown without a check in growth, there is no variety to compare with Giant Colorado Pascal. Our strain of this variety is a great improvement over the old strain. It grows much larger and is of exceptional quality. Forms solid, crisp stalks of a rich, nutty flavor. It is of strong growth, blanches easily to a rich, creamy white. An excellent keeper for Winter use, retaining its color and fresh appearance for a long time. Commands a premium on the market, but must be carefully packed in shipping because it is so brittle. If you want the finest quality Celery for table use or shipping, this is the variety for you to plant. Prt. 20c; $1 / 2$ oz, 45c; oz, 70c; $1 / 41 \mathrm{~b}, \$ 2.00 ; 1 \mathrm{~b}, \$ 5.75$, postpaid.
434 Utah. (130 days). Excellent for Fall use or Winter keeper. A favorite because of its tender, crisp and succulent stems and its peculiarly mild flavor. The stems are round, not moon-shaped. Bred especially for its freedom from hollow stalks. Originally grown only in the Utah valley, it is rapidly gaining a worldwide reputation. Pkt, 20c; 1/ 0z, 45c; 0z, 70c; $1 / 4$ 1b, \$2.00; 1b, \$5.75, postpaíd.

433 Giant Pascal. (140 days). The old standard Winter Celery. Plrt, 5c; $1 / 2$ oz, 15c; 0z, 25c; $1 / 4 \mathrm{lb}, 75 \mathrm{c} ; \mathrm{lb}, \$ 2.25$, postpaid.

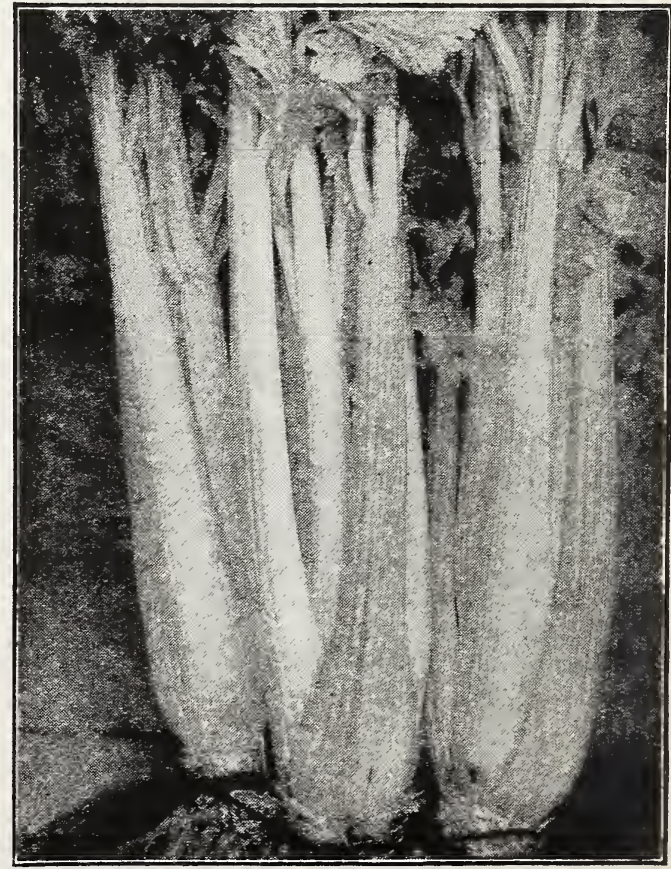

Giant Colorado Paccal. 


\section{Cauliflower}

For Cauliflower plants see page 48

The mountain districts of the Rocky Mountain region off $\in \mathrm{r}$ ideal conditions for the commercial growing of Cauliflower. The cool nights, rich soils, and bright sunshiny days of these sections are exactly the right combination for the successful culture of this fine vegetable.

Although Cauliflower is considered a hald crop to raise in most sections of the country, it is not so in the

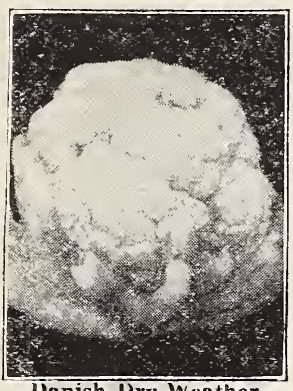

Danish Dry Weather Cauliflower. flower is not a crop that can be raised on a large scale, unless one is equipped with capital and labor to carry on large scale operations. But when one conper acre in the mountain districts is over $\$ 300$, you can readily see that a few acres
will give very good returns. CAUTIFIOWER IS EAST TO

Culture. One ounce for 2,000 to 3,000 plants; 8,000 plants to the acre.

For early Cauliflower, indoors or in hotbeds, when severe weather is past, set the plants in the field $21 / 2$ feet apart the plants in May and transplant to the field during July. Water freely, especially when heading. When the head begins to form fold the leaves over the head and secure them by pinning with a wooden pin. 422 Special Strain Danish Snowball. (110 days). Grown specially for us by the most successfui Cauliflower Seed grower, Einar Suhr. You want the best, here is the proof. Einar Suhr's seed is used by K. De Jong, of East Kildonan, Manitoba. Mr. De Jong has won the first prize as the Champion Caulifiower Grower of the United States and Canada for three successive years. Mr. De Jong has used nothing but Einar Suhr's seed. Our Special Strain Danish Snowball is grown specially for us in Denmark under contract by Einar Suhr. Mr. Suln advises that he has nothing better than the strain he is growing for us. We recommend our Special Strain in preference to all others because it produces heads of a perfect white color and entirely free from dark spots. Also, it produces large heads which are very solid and run extremely uniform throughout the field. This is the strain that Einar Suhr says is the best, and it has certainly been proven that he lknows, by his seed winning

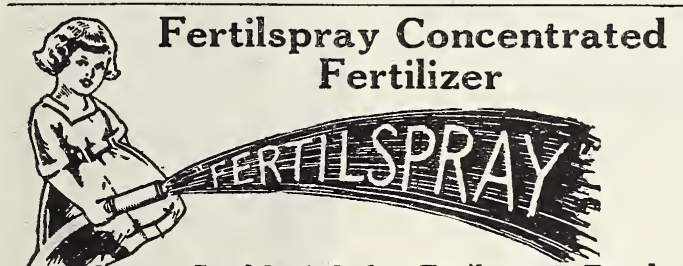

Is Adapted for Fasily and Eveniy

Applying with the Garden IIose A very highly water soluble concentrated Fertilizer and Plant Food, especially prepared for Lawns, Flowers, Shrubbery and Gardens.

Supplies Nitrogen, Phosphorus, Potash and other ecessary plant food elements.

Promotes healthy growth and rich color to foliage.

Contains no germs, odor, or weed seeds and does not draw flies or soil pests

Will not leach from the soil and may be applied any time as it positively cannot burn.

Cost is only $\$ 1.50$ postpaid per carton, covering 1,000 square feet and containing more actual plant food than is in bulky fertilizers costing more.

Why tolerate offensive odors, dirt, germs and unsightliness as well as invite soil pests and flies, with growth of weeds and objectionable grasses? You Must Water-You Must Fertilize Do Both at Once

FERTITSPRAY SPRAYIR

For applying Concentrated Fertilizer. Attaches to garden hose. Price, 50c, postpaid.

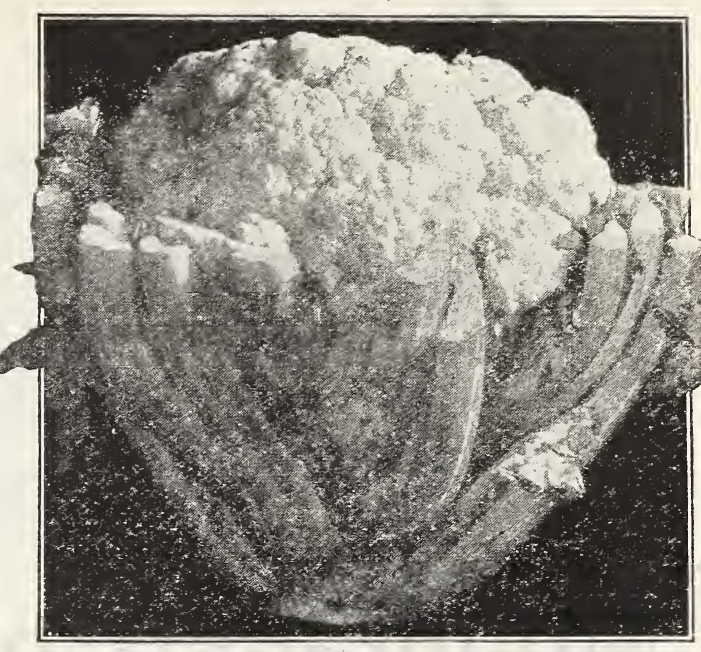

Special Strain Danish Snowball Cauliflower.

first prize for three successive years. Pirt, 25c; $1 / 4$ oz, $\$ 1.10$; oz, $\$ 3.25$; 1/4 1b, $\$ 9.00$; 1b, $\$ 27.00$, post-

423 Farly Danish Snowball. (110 days). Not the prize-winning strain listed above, but an excellent commercial strain. Deep, solid heads, finely grained and pure white in color. The plant is compact, but not too short leaved. Crop matures with great 70c; oz, \$2.10; 1/4 1b, \$7.00; 1b, \$22.25, postpaid. 421 SETF-PROTECTING DWART ERTURT. (115 days). Also known as Improved Self-Protecting Snowball; has leaves which naturally cover the head to a considerable degree, and is more easily blanched. Will not form as clear white heads as our Special Strain Danish Snowball. Pkt, 15c; $1 / 4 \mathrm{oz}, 60 \mathrm{c} ;$ oz, $\$ 1.70 ; 1 / 41 \mathrm{~b}, \$ 6.00 ; 1 \mathrm{~b}, \$ 19.25$, postpaid. 425 DANISI DRY WIATIFR. (125 days). A new strain bred to withstand more hot weather than pure white, and having much more foliage, must be planted farther apart. Where other varieties fail to head, we recommend this variety. Pkt, 15c; $1 / 4$ oz, 70c; oz, \$2.00; 1/4 Ib, \$7.00; 1b, \$22.25, postpaid.

The average bulky fertilizer is nearly all filler, which is necessary for spreading and as a diluter to avoid burning.

The Fertilspray method employs water as a dilutor and spreader, making filler unnecessary and burning impossible.

For Ferns and Potted Plants use FERTIISPRAY (Potted Plant Food).

Especially Prepared-\#ighly Concentrated

100 Treatments, 75 Cents; 25 Ireatments, 25 Cents, Postpaid.

\section{Trelife}

A Product Unexcelled for Sick Trees, Shrubs, Rose Bushes, etc.

Trelife is a Soil Tonic and makes available the necessary constituents for plant consumption, thereby increasing the growth.

Trelife also supplies iron to the soil (giving color and fragrance to flowers) and when combined with water is immediately soluble and ready to be absorbed by the roots; in addition, it contains a sufficient amount of sulphur, much needed to make other plant foods (which are already in the soil) available.

Trelife provides Nitrogen and Phosphoric Acid in just the correct proportions to produce luxuriant foliage and healthy fibrous root growth.

Trelife carries Copper Sulphate, which destroys soil pests and is also a most valuable fungicide Usually pests destructive to foliage breed or hibernate in the soil, which is the logical place to destroy them, rather than to make the attempt later when they are feeding on the foliage.

Trelife is odorless, easily applied and can be used at any season of the year.

Trees up to and including three years require $31 \mathrm{bs}$ : four years, 4 lbs.; older, 6 to 10 lbs.; shrubs and rose bushes, 1 to 3 lbs. 5 lbs., \$1.00, postpaid. Write for quotations on larger quantities. 


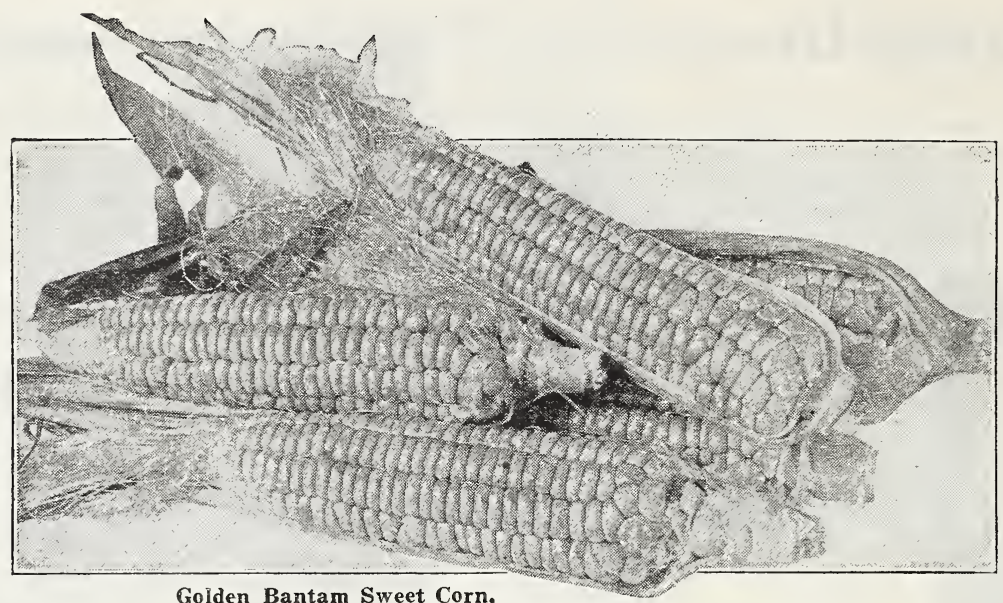

\section{Mountain Grown Sweet Corn}

THE DIFFFRETCF. The names of the varieties which we list are the same as those listed by other reliable seed companies. They are the same varieties. But they have been grown in the mountains at altitudes of 5000 to 6000 feet and they will mature earlier. Ten days earlier may not seem a great difference, but in many localities this is over ten per cent of the growing season. Do you, market gardeners, want to get your Corn on the early, high priced market? Do you, home gardeners, want to have Sweet Corn when it is still considered a

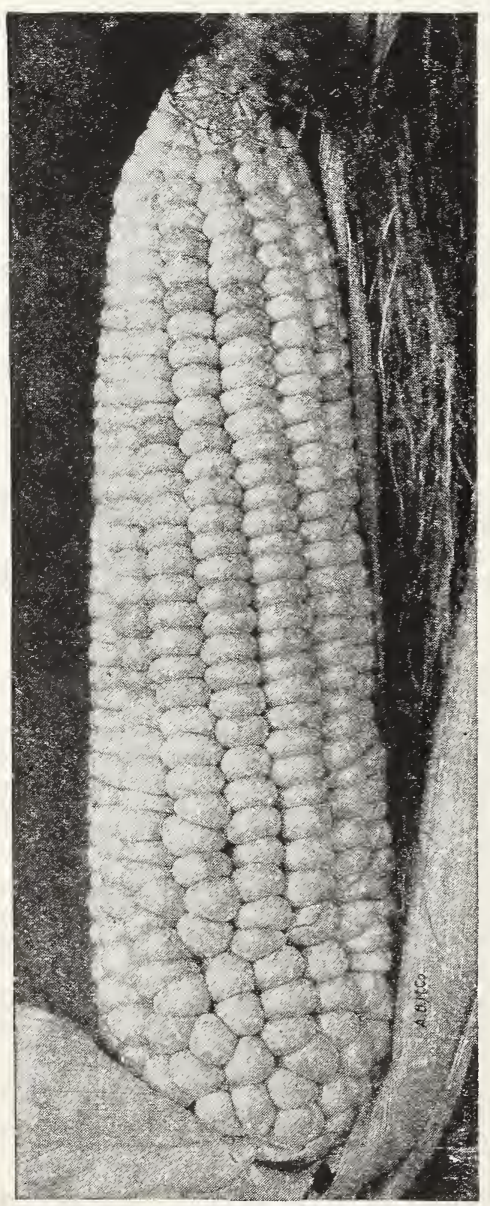

Adams Large Early. luxury? There is nothing in the vegetable kingdom hailed with as much delight, looked forward to with as much anticipation, as juicy Sweet Corn.

THE SWFFTrST CORN cannot be purchased, it must be home raised. It should be gathered for the table or for canning not more than two hours before it is cooked, as the quality and sweetness are injured by keeping longer than this. Sweet Corn is in the proper stage for gathering when the grains are plump and just entering the dough stage.

Culture. One pound to 400 feet of row; 10 pounds per acre. Rows should be laid off rabout three feet apart and seeds sown 1 to $1 \frac{1}{2}$ inches deep and 6 to 8 inches apart in the row. Or plant in hills 3 feet apart each way, leaving three plants to a hill. Growers often plant early corn before the normal season. Then, if the crop escapes frost, it matures earlier and is correspondingly valuable. If it is killed it may be cheaply planted again. In the home garden it is well to have a succession of plantings to supply the table during the season.

453 Sioux Squaw. (50 days). The earliest and hardiest corn. A hard flint corn when ripe, but is of fair table quality when in the dough stage. Grows only 3 or 4 feet high, but bears a good number of small cobs well filled with kernels of varying colors. Pkt, 5c; $1 / 2$ Ib, 20c: varying colors. Pkt, 5c; 1/2 Ib, 20c; $\$ 1.85 ; 25$ 1bs, \$3.75.

443 Peep o' Day. (62 days). The earliest real sweet white Corn. Even more dwarf in growth than the Golden Bantam, and with ears about the same size. The flavor of this variety is excellent. Pirt, 5c; $1 / 21 \mathrm{~b}, 15 \mathrm{c}$; 1b, 25c, postpaid. ITot prepaid, 10 lbs, \$1.85; $251 \mathrm{bs}, \$ 4.00$.

442 Adams' Iarge Farly. (75 days) Larger than Extra Early Adams, fair quality ears grow 8 inches long, 12 to 14 rowed. Similar to Extra Early Adams, but later. Pkt, 5c; 1/2 1b, 15c; 1b, 25c, postpaid. Not prepaid, 10 lbs, $\$ 1.60 ; 251 \mathrm{bs}, \$ 3.50 ; 1001 \mathrm{bs}, \$ 12.00$.

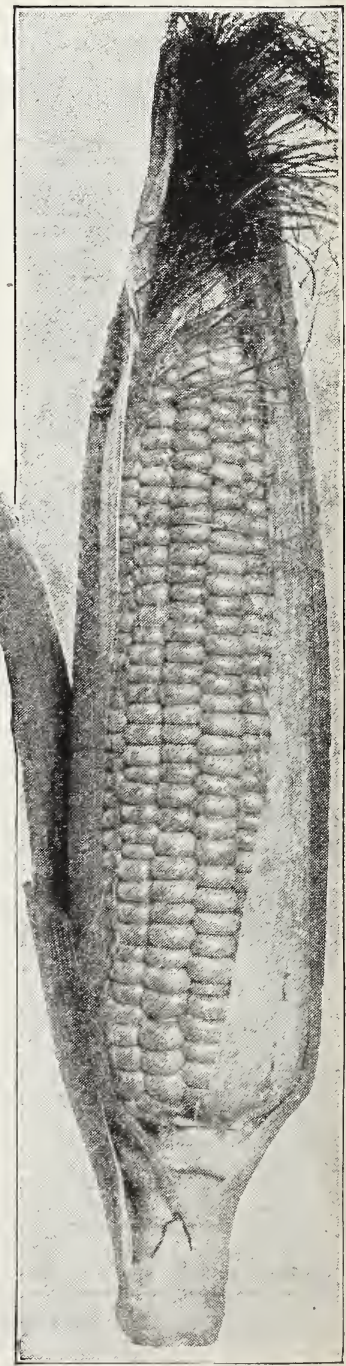

Golden Sunshine. 
441 Extra Early Adams. (60 days). Not a sweet or sugar corn, but the earliest white corn. Used extensively by market gardeners; very hardy, can be planted early and put on the market when roasting ears are high priced. Ears 7 to 8 inches long, 12 rowed. Pkt, 5c; $1 / 21 \mathrm{~b}, 15 \mathrm{c}$; $1 \mathrm{~b}, 25 \mathrm{c}$, postpaid. Not prepaid, $10 \mathrm{los}, \$ 1.60 ; 25 \mathrm{lbs}, \$ 3.50$; 100 lios, $\$ 12.00$.

439 Golden Sunshine. ( 60 days). The same flavor and color as Golden Bantam, but 10 days earlier. The ears are also larger, being 12-rowed instead of 8. Sunshine Corn is ready as early as the early white corns, it is early enough Veager of the North Dakota Experiment Station developed Golden Sunshine by crossing Golden Bantam with Portland Early Market. We obtained our original seed direct from Dr. Yeager. The plant is very dwarf and the ears close to the ground. We have grown a large seed acreage of Golden Sunshine, anticipating a big demand; do not disappoint us by missing this excellent variety. Pkt. 10c; $1 / 2$ lb, 25c; 1b, 40c, postpaid. Hot prepaid, 10 lbs, \$2.20; 25 lbs, $\$ 5.00$.

445 Golden Bantam. (70 days). America's favorite Sweet Corn. Very little need bo said of this variety as it is so well known. The very finest quality, golden yellow color. Hardy, and can be planted early, 8-rowed ears, 6 to 7 inches long. $\mathbf{B k t}, 5 \mathrm{c} ; 1 / \mathrm{lb}, 15 \mathrm{c} ; 1 \mathrm{~b}, 25 \mathrm{c}$, postpaid. Not prepaid, $10 \mathrm{lbs}, \$ 1.85 ; 25 \mathrm{lbs}, \$ 3.85 ; 1001 \mathrm{bs}, \$ 13.50$.

452 Golden Giant. ( 80 days). A cross between Golden Rantam and Howling Mob. Has the size of the latter and retains to a most remarkable degree the fine buttery flavor and high sugar content of the Golden Bantam. A strong grower and very productive. Plkt, 5c; $1 / 21 \mathrm{~b}, 15 \mathrm{c}$; 448 Stowell's Evergreen. (90 days). The all-purpose main crop variety. The grains, of good size, are long and slender, entirely free from glaze. Very tender and sugary; remains for a long time in condition suitabie for boiling. lbs, $\$ 1.75 ; 25$ 1bs, \$3.50; 100 1bs, \$12.75.

450 Country Gentleman. (95 days). The slender shoe-peg kernels of this variety are unsurpassed for flavor. They are very tender and sugary. This is a very productive variety with large ears of irregularly arranged kernels. Produces tender, sugary corn for the market or table after the other varieties have grown coarse or ceased to bear. Pl.t, 5c; 1/2 1b, 15c; 1b, 25c, postpaid. INot prepaid, 10 lbs, $\$ 1.85 ; 25$ lbs, $\$ 4.15 ; 100$ lbs, $\$ 15.00$.

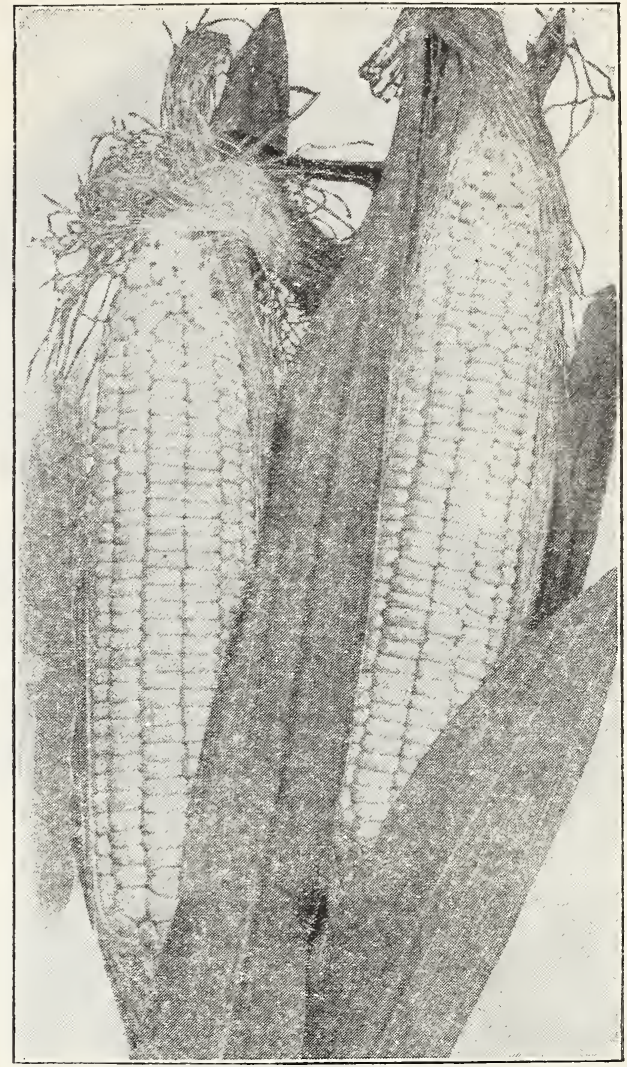

Golden Giant Sweet Corn.

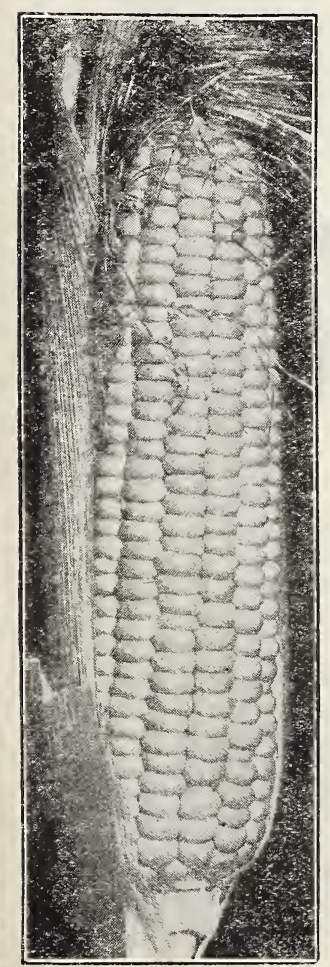

Stowell's Evergreen.

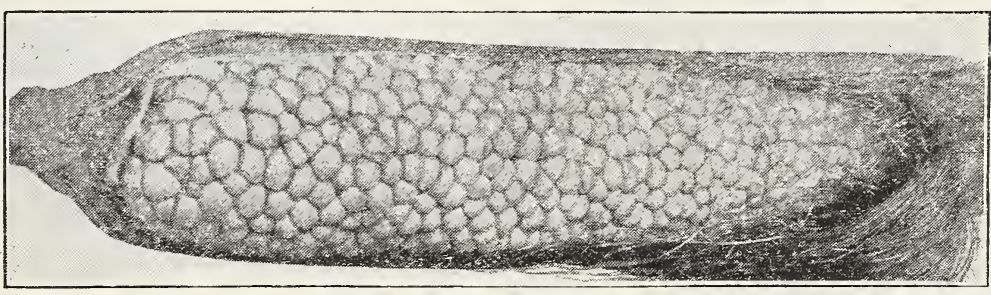

Country Gentleman Sweet Corn.

\section{Pop Corr}

Pop Corn is always a profitable crop. Every boy on the farm should plant at least a small patch Your local merchant will be glad to buy the crop from you

for his Christmas trade.

Culture -1 ounce to 40 feet of row-4 lbs. per acre.

After the ground is warm, sow in rows 3 feet apart. Always sow more than

one row so that the ears will be fully pollinated.

457 JAPANESE FUTIIESS, or Australian Fulless. A dwarf growing variety, bearing a good number of short, thick ears. This pop corn brings nearly double

the price of other varieties on the market. Kernels are long and very slim, but pop exceptionally large. Pkt, 10c; $1 / 2$ 1b, 20c; 1b, 30c, postpaid. Not prepaid, $10 \mathrm{lbs}, \$ 1.50$.

462 Mountain snowflake. Pops the largest of any variety. The popped grains of Mountain Snowflake are practically double the size of Japanese Hulless, and very much larger than any of the old types such as White

Rice, etc. The ears of Mountain Snowflake are large, and this variety gives a big yield per acre. Pkt, 10c; $1 / 216$, $20 \mathrm{c}$; 1b, 30c; postpaid. Not prepaid, 10 1bs, \$1.50; 25 1bs, $\$ 3.25$.

\section{CORN FOR POPPING}

Supplied at all times of the year. Prices are subject to market changes during the year.

Japanese Hulless. Not prepaid, 10 Ibs, $\$ 1.50$; $2.5 \mathrm{lbs}, \$ 3.10$.

Mountain Snowflake. Not prepaia, 10 lbs, $\$ 1.50$; $25 \mathrm{Ibz}_{\text {s }} \$ 3.25$.

White Rice. Fot prepaid, 10 lbs, \$1.15; 25 1bs, $\$ 2.55$.

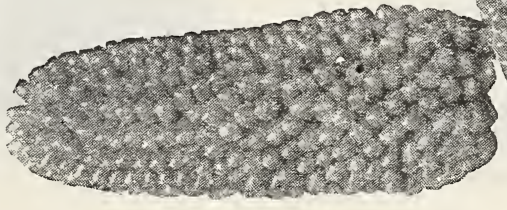




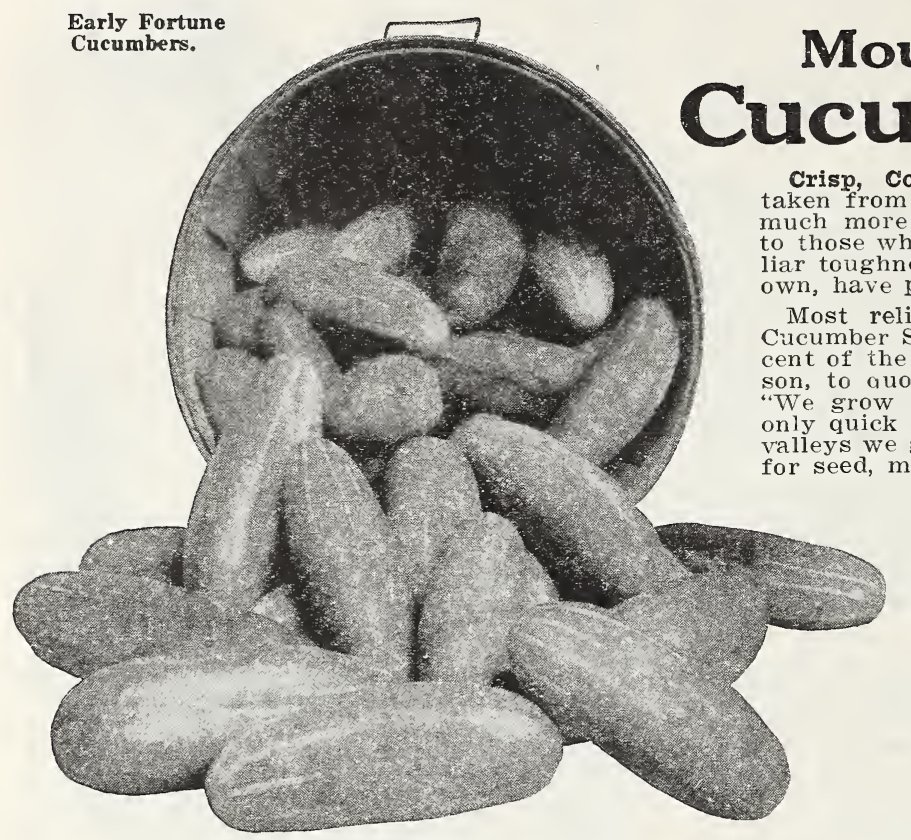

Crisp, Cool, Appetizing Cucumbers can only be more crisp and tender and of superior flavor which you can buy at the stores; that pecutoughness and bitterness is missing. Grow your

Tost reliable seed houses sell Mountain Grown Cumber Seed: in fact, Colorado supplies ninety per cent of the Cucumber seed to the country. The reaauote from a New York State seed catalog, our seed in high, altitudes to insure not "Wure results." In our of Cucumbers for seed, most of this seed being for southern truck farmers and eastern seed houses.

Culture. One ounce to 50 hills; 2 to 3 pounds per acre. After danger of frost is past plant in hills 3 by 6 feet apart and thin to 3 plants to a hill. Seed can be planted in boxes or paper pots in a hotbed, but Cucumbers do not transplant readily unless a mass of soil adheres to the roots. Pick fruit as soon as large enough to use, do not allow any Cucumbers to ripen on the vines.

\section{White Spine Varieties}

For slicing or shipping. White Spine types are all good shippers as they do not turn yellow. They are not good pickling varieties as they do not stay as solid when pickled. They are excellent for slicing.

479 Ward's Dark Green. (50 days). A very valuable early type of cucumber. It keeps green, that is, retains its deeper green color longer than any other variety. Very early and probably the most prolific of the White Spine types. Ward's Dark Green is the result of a number of years of careful selection from the Kirby Staygreen or Black Diamond type. This continual selection has made the type, shape and size much more even, while retaining to the full extent the earliness and remarkable yield of the parent variety. Among the smallest slicing and shipping types, averaging 7 inches in length. Pkt, 10c; oz, 20c; 1/4 1b, 45c;1b, $\$ 1.40$, postpaid. Not prepaid, 5 1bs, $\$ 6.50 ; 10 \mathrm{lbs}$. $\$ 12.50,25 \mathrm{lbs}, \$ 30.50$.

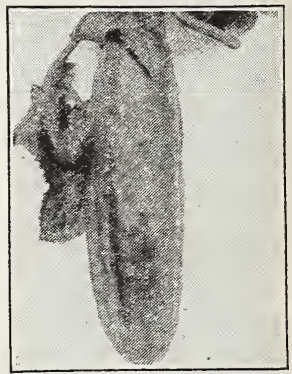

Henderson's Perfected.

483 Improved Early White Spine. (60 days). Early and productive. Cucumbers are quite uniform, 7 to 8 inches long, well rounded at the ends, and a bright green color. Fine for slicing, but not as good a shipper as some of the newer types. Pkt, 5c; oz, 15c; $1 / 4$ 1b, 45c; 1b, $\$ 1.35$, postpaid. INot prepaid, 5 lbs, $\$ 6.25 ; 10$ ibs, $\$ 12.00$.

468 Earliest of All. (48 days). Attractive dark green color, smooth and very symmetrical. Mainly used for early market. Length 7 inches. Plrt, 5c; $0 \mathrm{z}, 15 \mathrm{c} ; 1 / 4 \mathrm{bb}, 45 \mathrm{c} ; 1 \mathrm{~b}, \$ 1.40$, postpaid. Not prepaid, $51 \mathrm{bs}, \$ 6.50 ; 101 \mathrm{bs}$, $\$ 12.50$.

480 Henderson'ঞ Ferfected White Spine. (58 days). An excellent medium early slicing and shipping type, this variety shows a trace of the Emerald cucumber, thus securing a deep green color. Vines are hardy and prolific. Fruits are smooth and very uniform. Length 8 inches. Plst, 10c; oz, 20c; $1 / 4 \mathrm{lb}, 45 \mathrm{c}$; 1b, $\$ 1.35$, postpaid. Not prepaid, $5 \mathrm{lbs}, \$ 6.25$; $10 \mathrm{lbs}$, $\$ 12.00$; $25 \mathrm{lbs}, \$ 29.50$.

470 Farly Fortune. (58 days). Very attractive slicing and shipping variety. Early, productive and disease resistant. Cucumbers 9 inches long, slightly tapering and with distinct light stripes at the blossom end. Flesh firm, holds up well in shipping. The shipping trade find our continual selection makes this variety very uniform. Plkt. $5 \mathrm{c} ; 0 \mathrm{z}, 15 \mathrm{c} ; 1 / 4,1 \mathrm{~b}, 45 \mathrm{c} ; 1 \mathrm{~b}, \$ 1.35$, postpaid. Not prepaid, $5 \mathrm{lbs}, \$ 6.25$; $10 \mathrm{lbs}, \$ 11.25 ; 25 \mathrm{lbs}, \$ 26.50$.

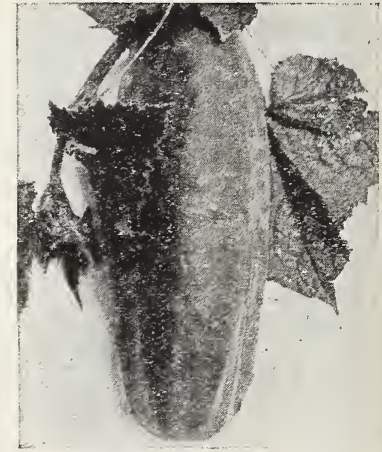

Earliest of All.

475 Davis Perfect. (65 days). A beautiful slicing Cucumber. An excellent shipping type, fruits are long and very attractive. Firm white flesh and few seeds. Good deep green color and holds up well. Does fine in the open ground, although this was originally a greenhouse type. Davis Perfect is one of the varieties on which we have done particularly careful selection work as it is of such great value to the commercial gardener. Length 10 inches. smooth and tapering at both ends. Pkt, 10c; oz, 20c; $1 / 41 \mathrm{~b}, 45 \mathrm{c} ; 1 \mathrm{~b}, \$ 1.35$, postpaid. Not prepaid, $51 \mathrm{bs}, \$ 6.25$; $10 \mathrm{lbs}, \$ 12.00$; 25 Ibs, $\$ 29.50$.

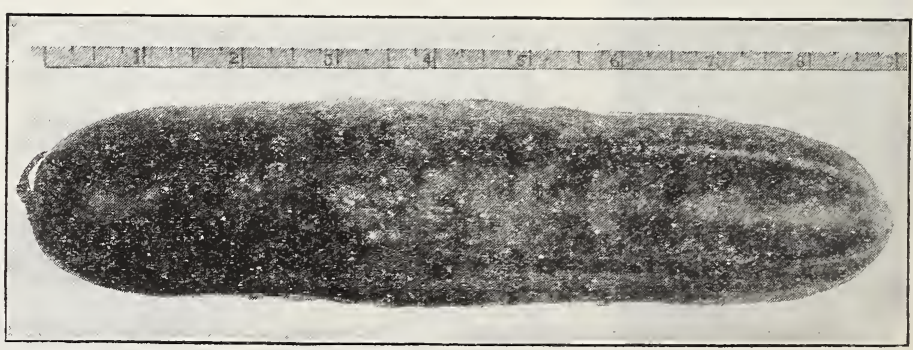

Davis Perfect Cucumber. 
WHITE SPINE VARIETIES-Continued

474 Roadside Market wonder. (70 days). An ideal type for the private garden or market gardener selling to a critical trade. A long, slender, dark green variety, suitable for outdoor culture or for greenhouse forcing. Firm, white flesh, few seeds and superb quality for slicing. Vines are vigorous and plants do well in any good soil. Length 12 inches. Pkt, 10c; oz, 25c; 1/4 1b, 65c; $1 \mathrm{~b}, \$ 1.85$, postpaid. Not prepaid, $5 \mathrm{lbs}$, $\$ 8.75 ; 10$ ibs, $\$ 17.50$.

471 Mountain Perfection. ( 75 days). The longest of all varieties and has an attractive dark green color. Retains it.s color and remains in good edible condition for a remarkably long time. The vines are prolific for such 'a large variety. Mountain Perfection has a small seed cavity and very few seeds. This variety requires a rich or well fertilized soil. Plxt, 15c; oz, 45c; 1/4 1b, \$1.30; 1b, \$4.25, postpaid. Not prepaid, 5 los, \$16.50.

Improved Long Green.

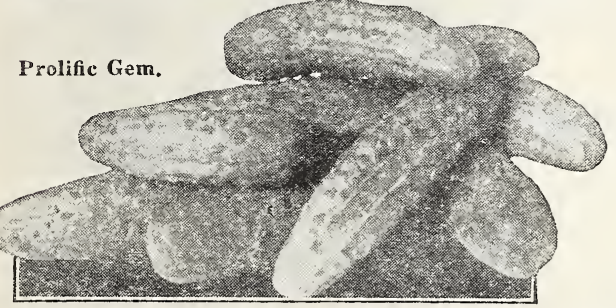

These are used mainly for pickling as they make fine, solid pickles that keep in excellent condition. The longer varieties are also used for slicing. Black Spine types are not suitable for shipping, as they do not hold solid long after picking.

477 Improved Iong Green. (65 days). The standard home garden, slicing and pickling type. Prolific, hardy and disease resistant. Beautiful long Cucumbers contain very few seeds, The small pickles are very well shaped, used both for small pickles and for dill pickles. Length 13 inches. Plit, $5 \mathrm{c} ;$ oz, $15 \mathrm{c} ; 1 / 4 \mathrm{lb}, 45 \mathrm{c} ; 1 \mathrm{~b}, \$ 1.35$, postpaid Not pxepaid, 5 los, $\$ 6.25$; 10 lbs, $\$ 12.00$.

486 Japanese Climbing. (60 days). A distinct type used for covering fences and trellises. Vigorous grower. Good quality. Length 9 inches. Fkt, 10c; oz, 20c, 1/4 1b, 45c; $10, \$ 1.35$, postpaid.

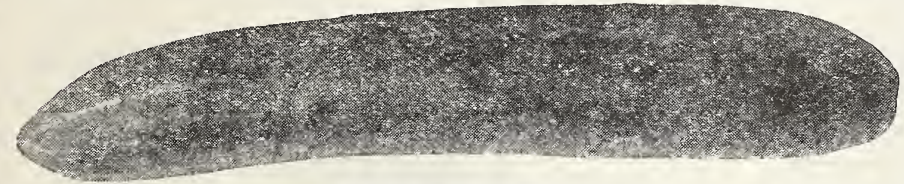

465 Chicago Pickling, Westerfield. (60 days). Very uniform type. Grows large enough to use for dill pickles. Pkt, 5c; oz, 15c; $1 / 41 \mathrm{~b}, 45 \mathrm{c} ; 1 \mathrm{~b}, \$ 1.35$, postpaid. Not prepaid, 5 1bs, \$6.25; $10 \mathrm{lbs}, \$ 12.00$.

466 Farly Ciuster. (55 days). A prolific

Mountain Perfection.

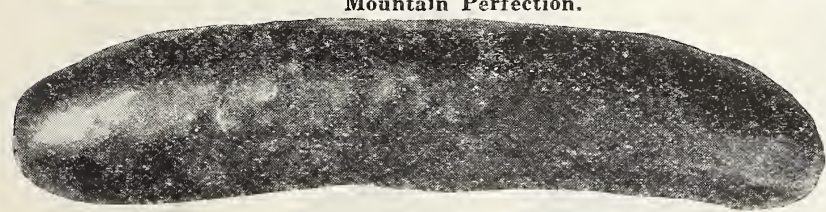

Roadside Market.

464 Boston Pickling. (55 days). Early and productive. Short, fairly smooth Cucumbers of very symmetrical shape. Plt, 5c; oz, 15c; $1 / 4 \mathrm{lb}, 45 \mathrm{c} ; 1 \mathrm{~b}, \$ 1.35$, postpaid. Trot prepaid, $5 \mathrm{lbs}, \$ 6.25 ; 10 \mathrm{lbs}, \$ 12.00$.

472 Everbearing. (70 days). If fruits are kept gathered, the vines will continue to bear through the season. A fine rariety for small pickles. Fkt, 5c; oz, 15c; $1 / 41$ 1b, 45c; 1b, \$1.35, postpaid. Not prepaid, 5 1bs, $\$ 6.25$.

463 West India cherkin. (60 days). A very prolific small fruited variety, vsed exclusively for pickling. Flesh pure white, skin a bright light green and covered with small elastic spines. Pkt, 10c; oz, 20c; $1 / 41 \mathrm{~b}, 60 \mathrm{c} ; 1 \mathrm{~b}, \$ 1.70$, post paid.

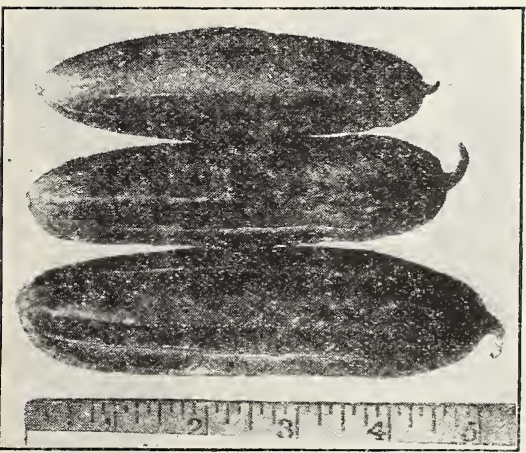

489 Ward's Iemon Cucumber. (70 days) Small fruits similar in shape an color to the lemon. Excellent for pickling or salads as it has a very delicate flavor which never becomes bitter. Also used for slicing just as the fruits are beginning to turn yellow. For pickling they can be used either green or ripe. Plst, $10 \mathrm{c}$; oz, 30c; $1 / 41 \mathrm{~b}, 90 \mathrm{c} ; 1 \mathrm{~b}, \$ 2.50$, postpaid.

I find your seed more anxious to get out of the ground and start growing than any I ever had before. GEO. $\mathrm{K}$. BRADFORD. Rayne, La.

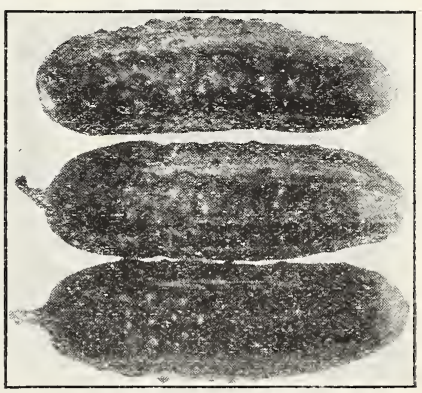

Everbearing Cucumber.

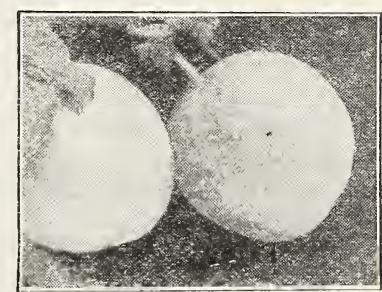

Ward's Lemon Cucumbers.

Chicago Pickling. 


\section{Broccoli}

Cultivated and used the same as cauliflower. Adapted to sections where the season is long and moist. Very hardy, standing great extremes of temperature. One ounce produces 2500 plants. 349 st. Valentine. Produces large, white heads which remain in good condition longer than cauliflower. Plt, 10c; $1 / 2 \mathbf{0 z}, 40 \mathrm{c}$; oz, $65 \mathrm{c} ; 1 / 41 \mathrm{~b}, \$ 2.00 ; 1 \mathrm{~b}, \$ 6.25$, postpaid.

348 Green Christmas Calabrese. Though often confused with the Italian Green Sprouting, the growth of this variety is quite distinct, and the Green Christmas Calabrese is quite a superior varjety. It is of branching growth with tender, loosely formed, delicious green heads. These loose heads are bunched for market and cooked like cauliflower. Plst, 15c; $1 / 2$ oz, 65c; $0 z, \$ 1.00 ; 1 / 41 \mathrm{~b}, \$ 3.50 ; 1 \mathrm{~b}, \$ 12.00$, postpaid.

\section{Asparagus}

(Asparagus Roots are listed on page 48).

Asparagus is not only a delicious home garden vegetable, but a very profitable one to grow for market.

254 IMary Washington. The Mary Washington is the highest type of the rust-resistant Asparagus. Very early, producing extra large shoots even the second year from seed. The buds or tips are tight, do not sprangle prematurely, retaining the flavor and keeping well. Pkt, 10c; oz, 25c;1/4 1b, 65c; 1b, \$1.75, postpaid. Not prepaid, 5 IJs, $\$ 7.25$.

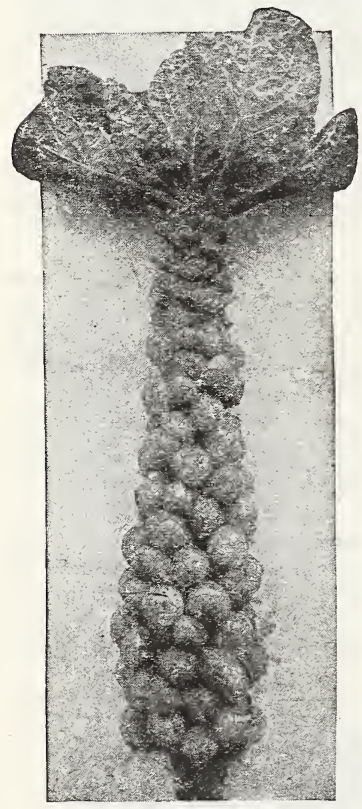

Brusseis Sprouts.

\section{Brussels Sprouts}

A quality vegetable for Fall and Winter use. Sprouts, like small cabbage, form on the long stalk of the

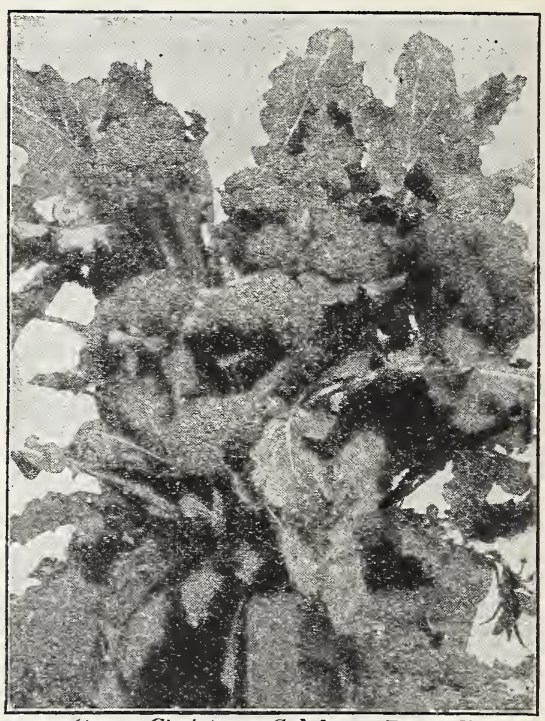

Green Christmas Calabrese Broccoli. plant. The quality and flavor of the sprouts are much improved by frost. Cultivate like hardy cabbage.

351 Iong Island Improved. (110 days). Earlier, more dwarf and compact than other varieties, the plants produce a large crop of tightly folded sprouts of delicious, sweet flavor. Pkt, $10 \mathrm{c} ; 1 / 20 \mathrm{O}, 20 \mathrm{c} ; 0 \mathrm{z}, 35 \mathrm{c} ; 1 / 4 \mathrm{lb}, 95 \mathrm{c} ; 1 \mathrm{~b}, \$ 2.75$, postpaid.

\section{Celeriac}

Turnip-rooted Celery. Forms a large turnip-shaped root with the flavor of fine celery. Splendid for stews, soups, etc. Easily stored for Winter use.

436 Irarge Smooth Prague. Fkt, 5c; oz, 20c; 1/4 1b, 65c; 1b, \$2.00, postpaid.

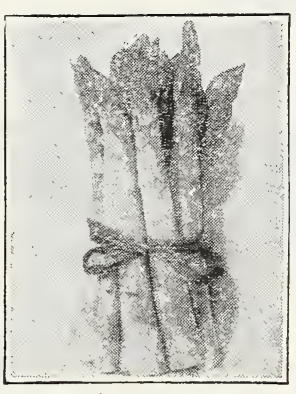

Asparagus.

\section{Chicory}

437 Witicof, French Endive. Forms long parsnip-shaped roots; the roots are forced in frames and the new lettuce-like leaves are served as a Winter salad. Pkt, 10c; oz, 25c; $1 / 410,60 c$; 1b, $\$ 1.50$,

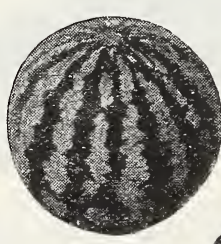

Citron.

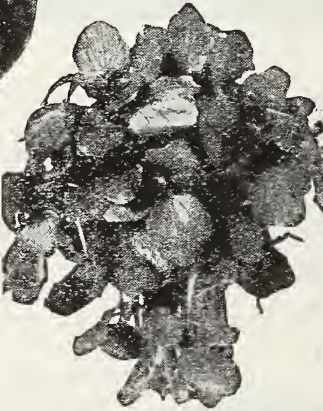

Water Cress.

\section{Cress}

\section{Collards}

440 True Georgia. Withstands heat and makes delicious greens. A vigorous variety, 3 feet tall, carrying a great quantity of large, succulent leaves. Pkt, 5c; $\mathrm{oz}, 10 \mathrm{c} ; 1 / 4 \mathrm{lb}, 30 \mathrm{c} ; 1 \mathrm{~b}, 80 \mathrm{c}$, postpaid. Irot prepaid, 5 Ibs, $\$ 3.50$.

\section{Corn Salad}

459 Broad-Ieaved. Gives the first spring greens if sown in the Fall. Can also be sown in July for Fall use. Beautifully blanched leaves for salads. Pkt, 5c: oz, 20c; ; 1/4 1b, 40c; 1b, \$1.20, postpaid. Not prepaid, 5 lbs, $\$ 5.00$.

\section{Extra Curled Garden.} at intervals during season. Pkt, $5 \mathrm{c} ; \mathrm{oz}, 15 \mathrm{c}$; $1 / 41 \mathrm{~b}, 30 \mathrm{c} ; 1 \mathrm{~b}, 80 \mathrm{c}$, postpaid. ing. Hardy plants, easily grown in ponds of fresh water or along edges of shallow running streams. Start seeds in pans of very moist earth. Plit, 10c; $1 / 2$ oz, 25c; oz., 40c; $1 / 416, \$ 1.25$; 1b, $\$ 3.75$, postpaid.

\section{Dandelion}

490 Improved Trick Leaf. An enormous crop of thick, fleshy leaves. Upright growth; blanches easily. Pkt, $15 \mathrm{c} ; 1 / 2 \mathrm{oz}$, 60c; oz, 85c; $1 / 41 \mathrm{~b}, \$ 2.60$; $1 \mathrm{~b}, \$ 8.25$, postpaid. leaves. Grows quickly. Sow seed in drills

461 Water Cress. For salads and garnish-
458 Iarge-

Rooted,

Madgeburg.

Roots a re roasted and ground as a coffee substitute or adulterant. Pkt, $5 \mathbf{c}$; Oz, 20c; $1 / 41 b$, ost prepaid, 5 Ios, $\$ 6.00$.

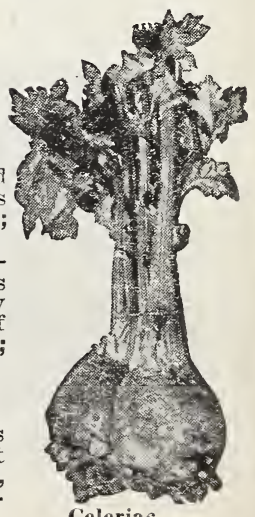

Celeriac. 


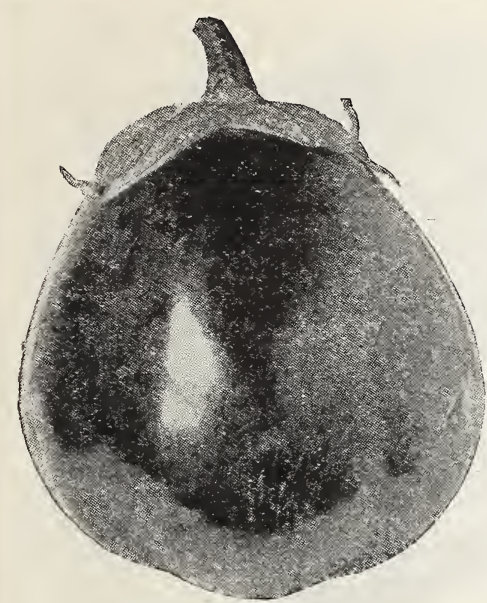

Black Beauty Eggplant.

\section{Eggplant}

A delicious vegetable that gives a decided change in the diet. To prepare for the table, slice and fry in butter.

Culture. One ounce to 1,500 plants, $1 / 41 \mathrm{~b}$. per acre. Start the plants in boxes or hotbed in March or April, set out plants the first of June.

492 Black Beaut, (110 days). Ten days earlier than New York and almost as large. Fruits uniform, blocky, oval shape and dark purple oz, 50c; $1 / 41 \mathrm{~b}, \$ 1.50 ; 1 \mathrm{~b}, \$ 4.75$, postpaid. Not. prepaid, $51 \mathrm{bs}, \$ 22.50$.

491 New York Improved. (120 days). Large fruits and entirely spineless. Oval shape, smooth and glossy, dark purple. Plants dwarf. Pkt, 10c; 1/2 oz, $30 \mathrm{c} ;$ oz $50 \mathrm{c} ; 1 / 4$ ib, $\$ 1.50$; $1 \mathrm{~b}, \$ 4.75$, postpaid. Not prepaid, $5 \mathrm{lbs}, \$ 22.50$.

493 Florida High Bush. (125 days). Plants grow four feet high and usually bear their fruits clear of the ground, preventing rotting. Large, oval dark purple fruits, Pkt, 10c; $1 / 2$ oz, 30c; oz, 50c; 1/4 1b, \$1.50; 1b, \$4.75, postpaid. Not prepaid, $5 \mathrm{Ibs}, \$ 22.50$.

\section{Endive}

One ounce will sow 300 feet of drill; 2 lbs. per acre. Plant from April to July, thin to 1 foot apart.

494 Green Curled Winter. (75 days). A tasty salad, of more attractive appearance than lettuce and more highly flavored. When fully grown tie tips of leaves together and center

leaves will quickly blanch a creamy white. Pkt, 10c; oz, 20c; $1 / 41 \mathrm{~b}, 40 \mathrm{c} ; 1 \mathrm{~b}, \$ 1.25$, postpaid. Not prepaid, $5 \mathrm{lbs}, \$ 4.75$.

495 Broad-Ieaved Batavian or Fscarolle. (90 days). Leaves are large and broad, forms a large head which can be readily

blanched, Ised as a flavoring for soups and stews, but is more generally coolked like spinach. Pkt, 10c; oz, 20c; $1 / 4 \mathrm{lb}$, 40c; $1 \mathrm{~b}, \$ 1.25$, postpaid. Not prepaid, 5 los, $\$ 4.75$.

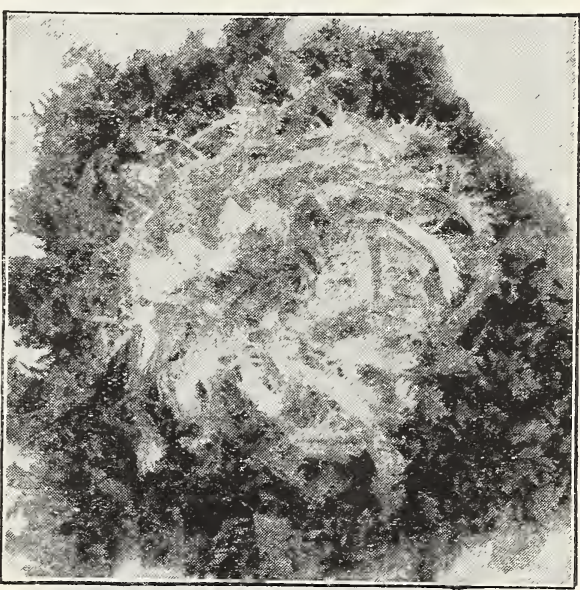

Green Curled Endive.

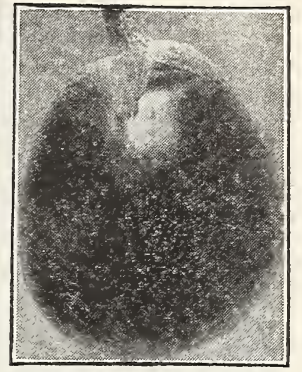

New York Improved.

\section{Herbs}

Sow in rich soil in shallow drills. When a few inches high thin out or transplant. Harvest on a dry day, just before they are in full blossom, dry and pack in dry, air-tight containers.

503 CARAWAY. Seeds used for flavoring, and in the making of cheese. Pkt, 5c; oz, 10c; $1 / 411$, 25c, postpaid.

506 DIr. Leaves and seed heads are used for flavoring pickles. Plkt, 5c; oz, 10c; $1 / 41 \mathrm{~b}, 25 \mathrm{c}$, postpaid.

$509^{2}$ IA VENDER. A perennial grown for its fragrance. making perfume. Plst, $10 \mathrm{c}$ $1 / 2$ oz, $45 \mathrm{c}$, postpaid.

Dill.

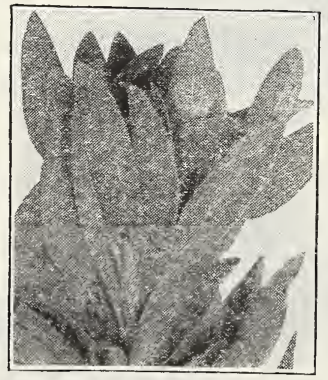

Sage.

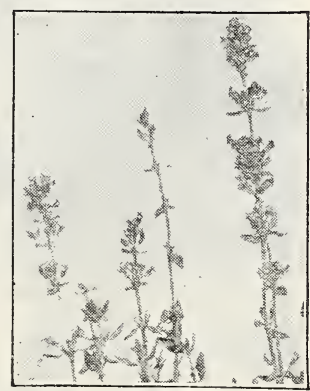

Thyme.

514 TFYMIE. Used for seasoning. A tea is also made for nervous headache. Pkt, 10c: $1 / \%$ oz, 40c; oz, 60c postpaid.

matic. The leaves and tops are used for seasoning
and stuffing. Pkt, 10c; 1/2 oz, 20c; oz, 30c; 1b, 90c, postpaid.

\section{Earlier, More Profitable Crops}

Germaco HOTKAPS can make many extra dollars for you this season. They are patented wax
paper cones-individual hothouses for each plant" 15 lars for you this season. They are patented wax that completely cover them, and fully protect them from frost, wind, rain, groundcrusting and insects. This is your assurance of earlier, bigger crops, and higher earlyto-market prices. HOTKAPS are inexpensive and easy to use. One man "sets" over 3,000 per day.

Prices, not prepaid, 12 for 35c; 100 for $\$ 1.75 ; 1000$ for $\$ 11.00 ; 5000$ at $\$ 10.50$ per 1000 ; $1.0,000$ or over at $\$ 10.00$ per 1000 . Shipping weight 30 lbs, per 1000 . Steel setter, $\$ 2.50$ garden setter, 50c. Trial offer, 100 Irothaps with garden setter, $\$ 2.00 ; 250$ with garden setter, \$3.75, not prepaid.

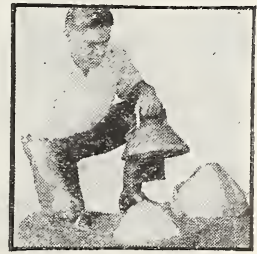




\section{Lettuce}

A valuable commercial crop when grown under proper conditions. Thousands of cars of Lettuce are shipped annually from the mountain states and California. A commercial acreage of Lettuce requires good, rich soil, no check in growth, careful weedins and thinning and cool weather during the heading season. These requirements must all be met to have a real success and to make big money from Lettuce. it is can, of course, be fertich has been in alfalfa or some such soil-building crop, or the rich natural soils of the high mountain valleys. The growth must never be checked or the plants will quickly shoot to seed and the crop lost. Under irrigation the growth can be generally controlled by watering. Careful weeding and thinning give the plants the full advantage of the fertility of the soil and also plenty of room for the heads to form and develop. Cool weather is necessaly at heading time; some varieties will stand hot weather, but the large heading varieties used by commercial shippers will not head in hot used as spring and Fall crops and not used to head in the summer.

MOUNTAIN GROWN IETIUCE SEED

Because of the importance of the Lettuce industry we are growing our Lettuce seed on our Mile High Farms. Here the season by our trained men, only perfect plants are seed will be as near perfect as our care can make them. This mountain growing of the seed also tends to make the varieties early in maturity and gives the seed strong vitality.

Culture. One oz. to 100 feet of drill; 2 to 4 lbs. per acre. Mountain Iceberg and New York or Wonderful require only $1 / 2$ to $1 \mathrm{lb}$. per acre. Lettuce is quite hardy and may be sown before danger of frost

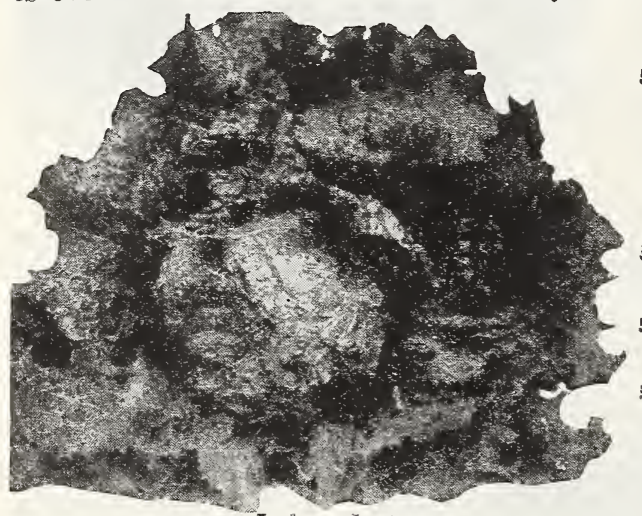

Iceberg Lettuce.

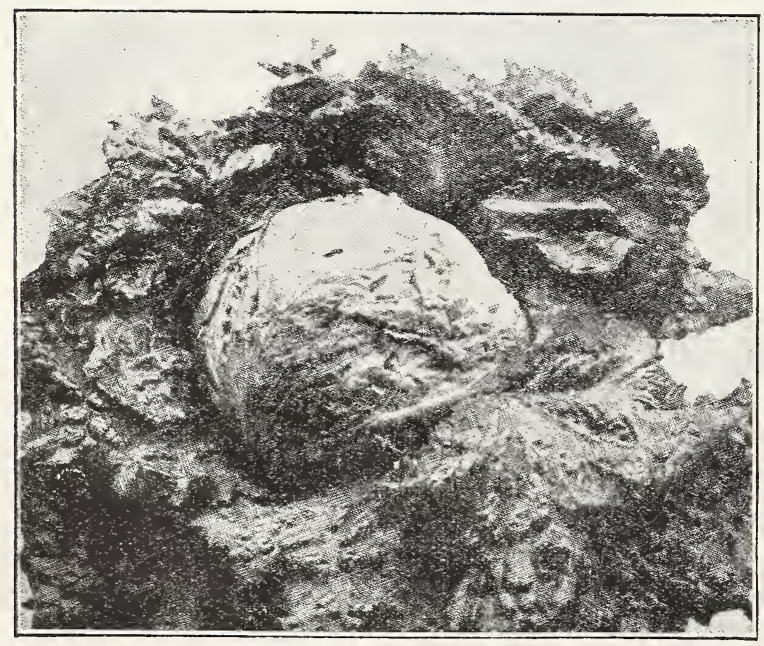

Mountain Iceberg Letuce.

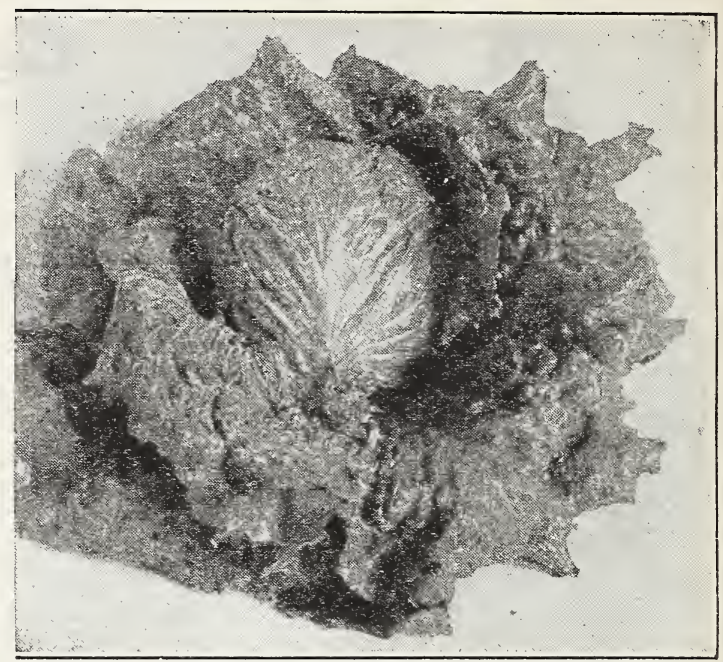

Special Strain New York Head Lettuce.

to 30 inches apart. When the plants have developed four leaves they should be thinned to 6 inches apart on the smaller varieties and 14 inches apart on New York or Wonderful and Mountain Iceberg. The quality of the crop depends to a large degree upon the moisture conditions and the plants should never be allowed to become checked in growth for want of water. Any such checking is apt to cause many plants to go to seed or produce unmarketable heads. Head Lettuce requires frequent, shallow cultivation and plenty of attention, so that one man should not attempt to handle more than 3 to 5 acres.

544 Special Strain New York. (80 days). Our strain of this popular variety was grown on our Mile High Seed Farms at 5000 feet elevation. We have never seen any finer, harder heads of Lettuce than those in our seed fields which we selected for seed last Summer. The field was thoroughly rogued so that vou can bank on this seed being absolutely true to type. Flst, $10 \mathrm{c} ; 1 / 20 \mathrm{Oz}, 20 \mathrm{c} ; \mathrm{oz}, 30 \mathrm{c} ; 1 / 41 \mathrm{~b}, 75 \mathrm{c} ; 1 \mathrm{~b}, \$ 2.00$. postpaid. Not prepaid, $5 \mathrm{lbs}, \$ 8.50 ; 10 \mathrm{lbs}, \$ 16.00$.

537 Special Strain New York (2-year-old seed). Plkt, 10c; $i / 20 z, 20 \mathrm{c} ; \mathrm{Cz}, 30 \mathrm{c} ; 1 / 4,1 \mathrm{~b}, 85 \mathrm{c} ; 1 \mathrm{~b}, \$ 2.40$, postpaia. Tot prepaid, 5 1bs, $\$ 10.50 ; 10$ Ibs, $\$ 20.00$.

545 Special Strain New York (3-year-old seed). Pkt, 10c; $1 / 20 z, 20 \mathrm{c} ; 0 z, 35 \mathrm{c} ; 1 / 41 \mathrm{~b}, \$ 1.00 ; 1 \mathrm{~b}, \$ 2.90$, postpaid. Not prepaid, $5 \mathrm{lbs}, \$ 13.00$.

543 Fxtra Early 5084 New York. (70 days). A brand new strain of New York Lettuce selected for extreme earliness. It produces well rounded, tight, solid heads about two weeks earlier than any other known strain, and the top of the head has a well grown leaf which protects greatly from sunscald. See page 2 for illustration and further description. Pkt, 15c; $1 / 2 \mathrm{oz}, 30 \mathrm{c} ; \mathrm{oz}, 45 \mathrm{c} ; 1 / 4 \mathrm{k}, \$ 1.10 ; 1 \mathrm{~b}, \$ 3.20$, post541 Miourtain Iceberg. ( 80 days). Very similar to 41 Iiourstain Iceberg. (80 days). Very similar to New York or Wonderful. Our mountain grown high altitude Lettuce growing. A hardy, rapid grower, deep rooted and drought resistant. Will stand in cutting condition for several weeks. Produces closely folded, solid heads of immense size, often weighing 2 or 3 lbs. The inner portion is beautifully blanched to a creamy white. The heart is solid, sweet, tender and crisp. Plt, 10c; $1 / 2$ oz, 20c; oz, 30c; $1 / 4 \mathrm{Ib}, 75 \mathrm{c} ; 1 \mathrm{~b}, \$ 2.00$, postpaia. Irot prepaid, $5 \mathrm{lbs}, \$ 8.50 ; 10 \mathrm{lbs}, \$ 16.00$.

542 Mountain Iceberg (2-year-old seed) Prt., 10c; $1 / 2$ oz, 20c; oz, 30c: $1 / 41 \mathrm{~b}, 85 \mathrm{c} ; 1 \mathrm{~b}, \$ 2.40$, postpaid. Not prepad, 5 lbs, $\$ 10.50 ; 10 \mathrm{lbs}, \$ 20.00$.

546 Mountain Iceberg (3-year-old seed). Fit, 10c; $1 / 2$ oz, 2Cc; 0z, 35c; 1/4 1b, \$1.10; 1b, \$2.90, postpaid. Not prepaid, 5 lbs, \$13.00.

539 Improved Finson. ( 80 days). The most reliable variety for general planting; stands hot weather better than any other type. Sure heading even in midsummer. Good sized heads. Large, crumpled leaves. Fkt, $5 \mathrm{c} ; \mathbf{c z}, 15 \mathrm{c} ; 1 / 4 \mathrm{1b}, 40 \mathrm{c}$; 16, $\$ 1.20$, postpaid. Not prepaid, 5 ibs, $\$ 5.00$.

538 Iceberg". ( 80 days). Crisp and brittle, too brittle for shipping, but excellent for home gardens. Curly leaves and fine flavor. Will stand considerable hot weather. Quite distinct from the varjety known to the produce markets as "Iceberg." That variety is "New York." Pkt, 5c; $02,15 c: 2 / 4,1 b, 50 c$;
pais, 5 ibs, $\$ 0.50$. 


\section{LETTUCE-Continued}

535 California Cream Butter (65 days). Valued for its heat resistance. A popular variety, especially for Autumn and Winter use. Forms a very large head, which is exceedingly buttery in texture. Fkt, 10c; $02,20 \mathrm{c} ; 1 / 41 \mathrm{~b}, 50 \mathrm{c} ; 1 \mathrm{~b}, \$ 1.45$,
postpaid. Not prepaid, $51 \mathrm{bs}, \$ 6.25$.

534 Mammoth Big Boston (75 days). Early and hardy, Big Boston grows to an enormous size, well grown heads measuring from 10 to 12 inches across. Grows well during hot weather, but during the cool weather it heads particularly well, forming a tightly folded heart which consists of beautifully blanched, tender, and juicy leaves. Fht, 5c; oz, 15c: $1 / 4$ 1b, 35c; 1b, \$1.25, postpaid. Not prepaid, $5 \mathrm{Ibs}, \$ 5.50$.

540 May King (60 days). Quickly forms fine hard heads, resembling small cabbages. It is hardy, will bear transplantgreen color, outer leaves tinged with brown. Tender, with a rich, buttery flavor. Pkt, 5c; oz, 15c; $1 / 41 \mathrm{~b}, 50 \mathrm{c} ; 1 \mathrm{~b}, \$ 1.45$, postpaid. Not prepaid, 5 lbs, \$6.25.

531 Paris White Cos. ( 80 days). Also called Trianon or Self Folding Cos. Forms a compact head, very dark green outside and well blanched inside. Much esteemed for its fresh

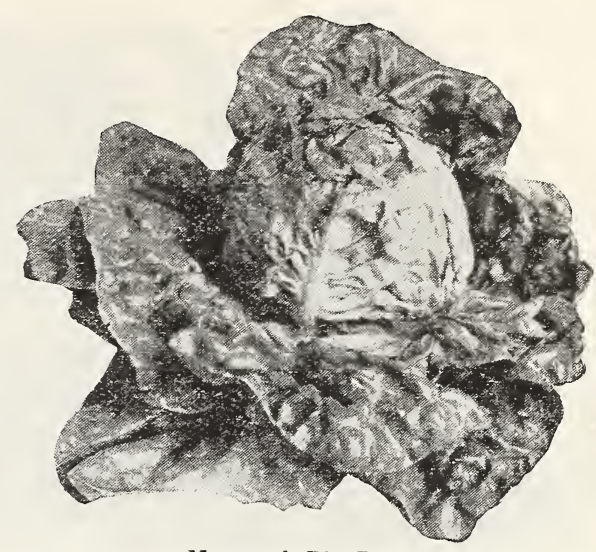

Mammoth Big Boston.

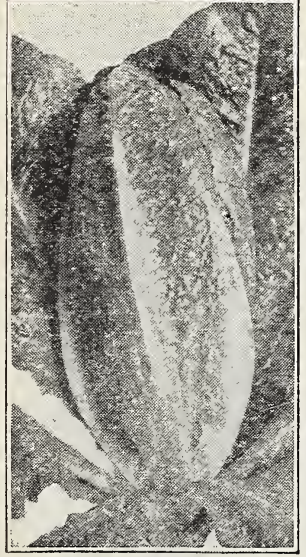

Paris White Cos. crispness and mild flavor. Pkt, 10c; oz, 20c; $1 / 41 \mathrm{~b}, 40 \mathrm{c} ; 1 \mathrm{~b}, \$ 1.30$, postpaid. Not prepaid, 5 Ibs, $\$ 5.75$.

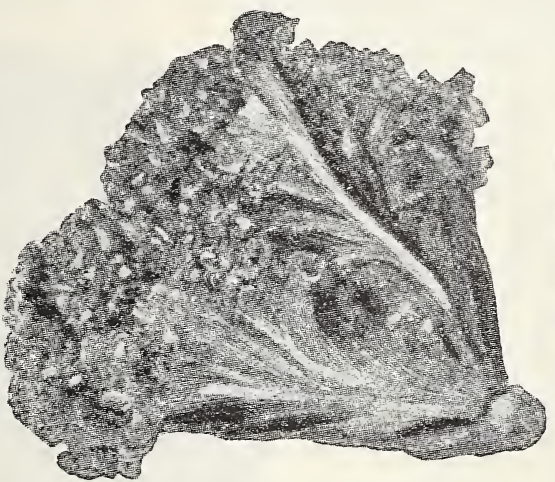

Black Seeded Simpson.

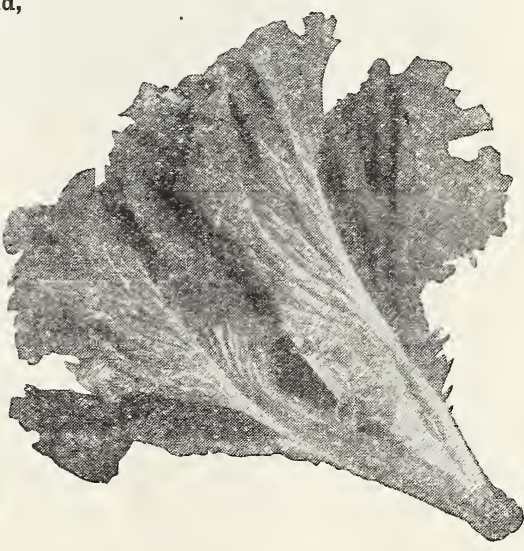

Ward's Improved Grand Rapids.

\section{Leaf Lettuce}

527 Ward's Improved Grand Rapids (60 days). Well adapted for early spring planting or for greenhouse forcing. It does not form a head, but produces beautiful long, curly or wrinkled leaves. It is extremely early, very hardy. tender, crisp, and of a rich green color. Our improved strain has never been known to fail to produce a good crop. A favorite both for the market and home gardener. Plkt. 10c; oz, 25c;1/4 1b, $70 \mathrm{c} ; 1 \mathrm{~b}, \$ 2.00$, postpaid. Not prepaid, $5 \mathrm{lbs}, \$ 8.00 ; 10$ Ibs, $\$ 15.25$.

526 Grand Rapids ( 65 days). Leaves heavily curled, and of crisp texture and fine flavor. Pkt, $5 \mathrm{c} ; \mathrm{oz}, \mathbf{1 5 c}$; $1 / 4 \mathrm{lb}, 40 \mathrm{c} ; \mathrm{lb}, \$ 1.25$, postpaid. Not prepaid, 5 lbs, $\$ 5.50 ; 10 \mathrm{lbs}, \$ 10.25$.

528 Black Seeded Simpson (65 days). Very tender and excellent flavor Forms a large, loose head of broad, crumpled, light green leaves. Pkt, 5c; oz, 15c; 1/4 1b, 35c; lb, \$1.00, postpaid.

\section{SEMESA N}

Controls Seed-borne Diseases

Improves Germination and Crop Yields

\begin{tabular}{|cr|}
\hline \multicolumn{2}{|c|}{ PRICEs: } \\
\multicolumn{2}{|c|}{ Not Prepaid } \\
2-oz. tin $\$$ & .50 \\
1 1b. tin & 2.75 \\
5-1b. tin & 13.00 \\
25-1b. & \\
pail... & 56.25 \\
100-1b. & \\
drum. . & 220.00 \\
300-1b. & \\
drum.. & 645.00 \\
\hline
\end{tabular}

Freed of disease handicaps by disinfection with Semesan, fiower and vegetable seeds usually germinate quickly and vigorously and in larger percentages. When used as a dust, one pound of Semesan is sufficient to treat from 240 to 480 pounds of seeds, and nearly 1000 pounds in liquid form, making the cost ridiculously small. One ounce treats 15 pounds of seed.

529 Early Curled Simpson (60 days). The oldtime curly Lettuce, and still very popular. A bunch of leaves at the center of the plant which are of excellent quality. Pkt, 5c; oz, 15c; 1/4 1b, $40 \mathrm{c} ; 1 \mathrm{~b}, \$ 1.25$, postpaid. Not prepaid, $5 \mathrm{lbs}, \$ 5.50$.

530 Early Prize Flead (75 days). A home garden favorite. Not a head Lettuce, but makes a large and distinct bunch of leaves at the heart when mature. Grows quickly and remarkably good flavor. Color is bright green shaded with light brown. Pkt, 5c; oz, 15c; 1/4 1b, 35c; 1h, \$1.00, postpaid. Not prepaid, 5 lbs, $\$ 4.40$.

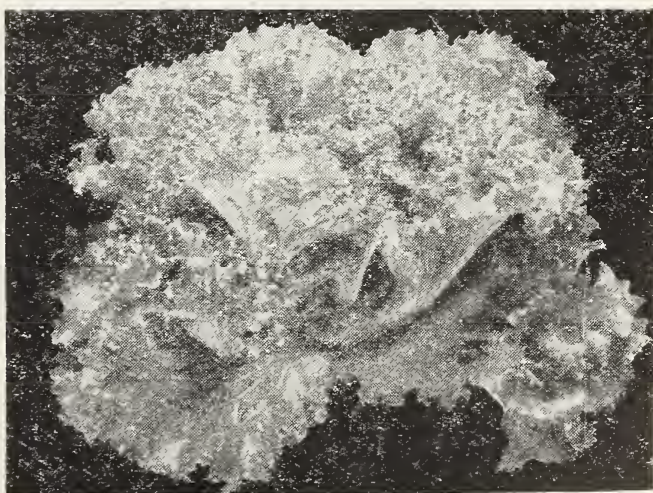

Early Curied Simpson. 


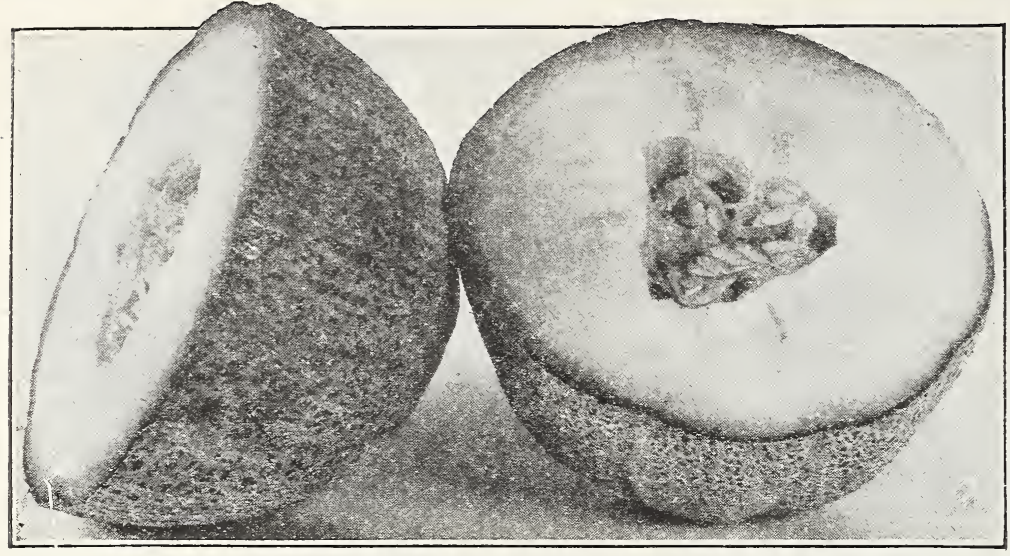

Hearts of Gold Cantaloupe.

\section{Mountain Grown Cantaloupe and Muskmelon Seed}

It is now generally recognized that the finest Cantaloupe seed is raised in Coiorado. The bulk of the seed used by shippers of Cantaloupes over the entire country is Colorado grown. We wish to draw your particular attention to the fact that our seed is hand cut from the choicest Melons in the field, no Melons are marketed from our seed fields.

On these pages we list not only Cantaloupes but also other varieties of Muskmelons. By the term "Cantaloupe" we designate varieties of Muskmelons that are suitable for shipping. Muskmelons have a fine flavor when they are just ripe, but the time for picking them in the best condition is very short. A Melon is just right for picking when it "slips" from the vine, that is, the stem does dition for a much longer time than other varieties of Muskmelons. Melons of all kinds are especially attractive to the gardener because they are practically the only vegetables of a long, lone list that can be classed with fruit.

Culture. One ounce of seed for 40 hills; two to four pounds per acre. The most suitable soil is a warm, sandy loam, rich and well worked. Plant as soon as danger of frost is past. Many market gardeners start planting very early and continue to plant a few hills every five days. When you consider that an early crop will often bring thousands of dollars per acre, and that the seed costs less than five dollars per acre, you will see that the frost damaged hills can be readily re-seeded. Some home gardeners secure early Melons by starting the seeds in boxes in the house. Sow the seed in hills 4 to 6 feet apart each way and cover to a depth of about one inch. When well up thin to two plants to a hill. 418 Ward's Icteal. ( 80 days). A careful selection of the perfectly round, heavily netted Rocky Ford type Cantaloupe. It has the very best flavor, being very sweet and delicious. It ripens clear to the skin. Ward's Ideal runs very uniform to standard size and with no pony melons. These Cantaloupes are perfectly round, have no ribs and have a very heavy netting, maling them ideal for shippers. The Ideal has thick orange flesh, free from stringiness, and a small seed cavity. Like all Cantaloupes it remains in good condition for a much longer time than Muskmelons: you do not have to be an expert to know when to pick Cantaloupes. Prt, 10c; $0 z, 25 \mathrm{c} ; 1 / 41 \mathrm{~b}, 70 \mathrm{c} ; 1 \mathrm{~b}, \$ 2.00$, postpaid. Not prepaid, $5 \mathrm{ibs}, \$ 3.00$; $10 \mathrm{lbs}, \$ 14.75 ; 25 \mathrm{lbs}, \$ 32.50$.

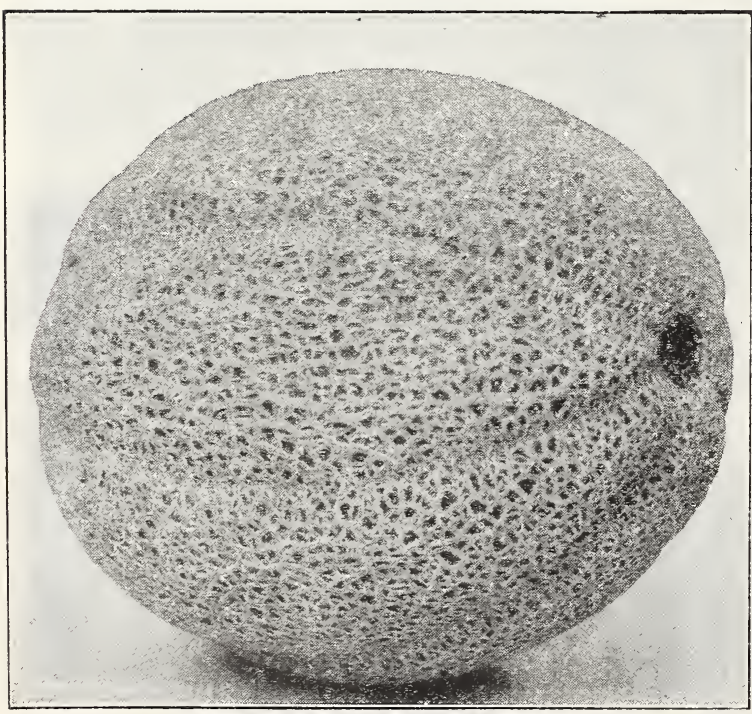

"H. B." Hale's Best Cantaloupe.

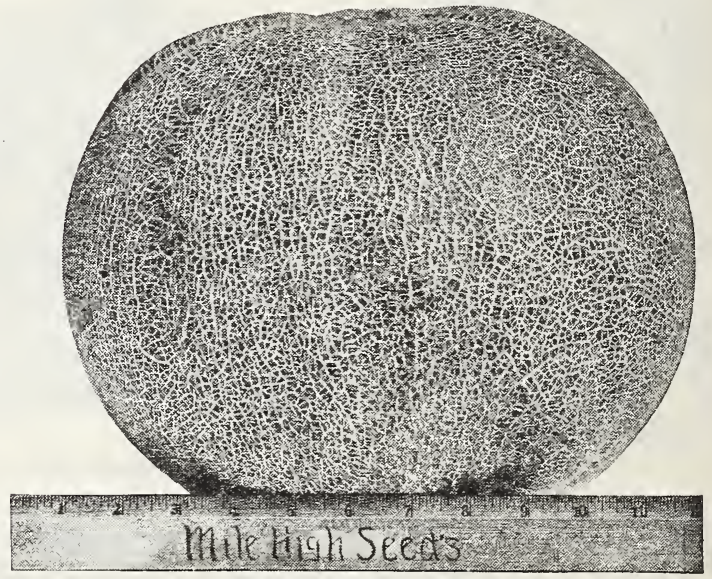

Roadside Market Melon.

409 Iearts of Gold. (80 days). One of the newer Cantaloupes of real merit. Has very thick, sweet flesh of a beautiful golden salmon color. The triangular seed cavity is only about the size of a half dollar and the Melon can be eaten almost to the rind. Good size, oval shape, fairly distinct ribs and heavy netting. An improved Hoodoo, being larger and with heavier netting. Plt, 10c; oz, $15 \mathrm{c} ; 1 / 41 \mathrm{~b}, 40 \mathrm{c} ; 1 \mathrm{~b}, \$ 1.30$, postpaid. Not prepaid, 5 los, $\$ 5.50 ; 25$ 1bs, \$24.00.

398 'FH. B."- Hale's Best. (70 days). A remarkably early shipping variety of excellent quality. Extensively used in the Imperial Valley, California. Melons are oval in shape, 8 inches long by $4 \frac{1}{2}$ inches in diameter with heavy netting and fairly distinct ribbing. Flesh very thick and of deep salmon color. Pirt, 10c; 0z, 20c; $1 / 4$ 1b, 50c; Ib, $\$ 1.50$, postpaid. Not prepaia, 5 1bs, \$6.50; 25 lbs, \$26.00. way Pink Meat and Defender. A slightly smaller Melon, similar in many ways to Hearts of Gold. Popular in some sections for home gardens and shipping Prt, $5 \mathrm{c} ; 0 \mathrm{z}, 15 \mathrm{c} ; 1 / 411 \mathrm{~b}, 35 \mathrm{c}$; 1b, $\$ 1.00$, postpaid. Not prepaid, 5 lbs, $\$ 4.50$.

408 Ferfected Perfecto. (85 days). A selection from Edward's Perfecto. It bears and ripens its fruit evenly and for a longer period than any other strain; for this reason is a favorite with many growers. Pkt, 10c; oz, 25c;1/4 1b, $7 \mathrm{Cc} ; 1 \mathrm{~b}, \$ 200$. postpaic. Not prepaid, 5 1bs, $\$ 7.75 ; 10$ Ils, $\$ 14.25 ; 30$ 1bs, $\$ 30.00$.
402 Rurrell's Gem. (85 days). Also called Ord- 


\section{MUSKMIIONS-Continued.}

410 Pollock 10-25. (85 days). Salmon-fleshed, fine flavored, standard Rocky Ford Cantaloupe. Round Melons, 5 inches in diameter, no ribs, heavy netting and excellent for shipping. Very thick salmon flesh, changing to green near the rind. Pkt, 5c; oz, 15c; $1 / 4 \mathrm{lb}, 40 \mathrm{c} ; 1 \mathrm{~b}, \$ 1.20$, postpaid. Not prepaid, $5 \mathrm{lbs}, \$ 4.75 ;$ $25 \mathrm{lbs}, \$ 19.00$.

400 Osage or Miller's Cream. (80 days). Large, main crop, orange-salmon fleshed Muskmelon. Thick flesh of luscious flavor. Small seed cavity. Can be shipped short distances. Large, oval-shaped Melons with indistinct ribs, green skin, and slight netting. Pkt, 5c; oz, 10c; $1 / 41 \mathrm{~b}, 30 \mathrm{c}$; 1b, \$1.00, postpaid. Not prepaid, 5 lbs, $\$ 4.50$.

412 Delicious, Gold Iined. (85 days). Very attractive, Rocky Ford Cantaloupe. Deep green flesh with a gold lining next to the seed cavity. Round, heavily netted, no ribs, excellent flavor. Pkt, 5c; oz, 150; $1 / 41 \mathrm{~b}, 35 \mathrm{c} ; 1 \mathrm{~b}, \$ 1.20$, postpaid. Trot prepaid, 5 lbs, $\$ 5.25 ; 25$ lbs, $\$ 22.50$.

413 Rocky Ford. (85 days). Rust resistant and the finest greenfleshed selection from the Rocky Ford type. This Cantaloupe runs very uniform to standard size. The netting is very heavy and dense, which, with the thick flesh, makes it an ideal long-distance shipper. The flesh is usually green with an occasional light golden tint. Fine grained, good flavor and very solid. Pkt, 5c; oz, 15c; 1/4 1b, 40s;

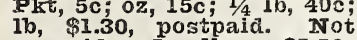
prepaid, 5 lbs, $\$ 5.50$; $25 \mathrm{lbs}, \$ 24.00$.

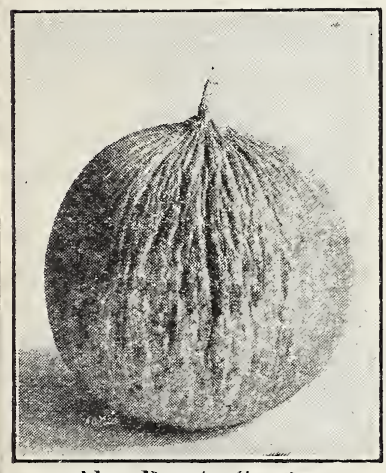

ciolden Beauty Casaiva.

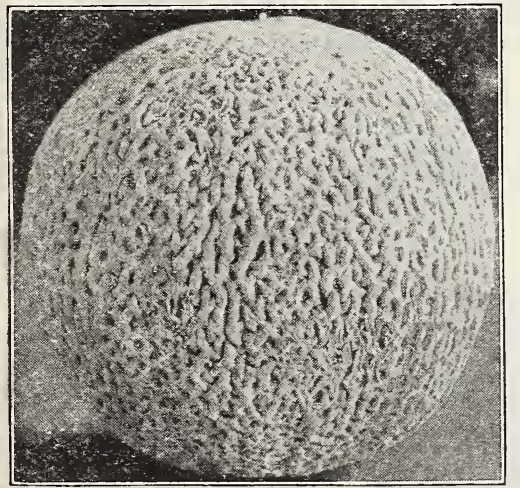

Delicious, Gold-Lined Cantaloupe.
403 Extra Farly Fackensack. (75 days). The earliest variety: a greenfleshed garden Muskmelon of good flavor. Widely used by home gardeners and market gardeners but not suitable for shipping. Flattened fruits have deep ribs and are coarsely netted. Pkt, $5 c ;$ oz, 10c; $1 / 417,30 c ; 1 b, \$ 1.00$, postpaid. Not prepaid, $5 \mathrm{lbs}, \$ 4.50 ; 25 \mathrm{Ibs}, \$ 20.50$.

414 Foneyball. (100 days). This new Melon has a flavor enjoyed by everyone, and it is really difficult to please evervone with one fiavor. The Honeyball is a cross between the Honey Dew and the Texas Cannon Ball. It has the appearance, shape and size of a Cantaloupe, very thick green flesh, of a delicious, aromatic flavor. The flavor is similar to the Honey Dew, but not as sweet and far more refreshing. The Honeyball is a good shipper, stays firm and keeps well in storage. Cannot be surpassed for the home garden. Fkt, $10 \mathrm{c} ; 0 \mathrm{z}, 20 \mathrm{c} ; 1 / 4 \mathrm{~b}, 60 \mathrm{c} ; 1 \mathrm{~b}, \$ 1.85$, postpaid. Not prepaid, $5 \mathrm{lbs}, \$ 7.50 ; 25 \mathrm{lbs}, \$ 29.00$.

405 Honey Dew. (110 days). Not a cantaloupe, but more a Fall or Winter Melon. The flesh is emerald-green, very thick, melting and fine grained. It can be eaten to the extreme rind, and the flavor is quite distinct and very sweet. It should be picked and stored before becoming fully ripe, when properly stored can be kept until Christmas. When ripe the skin is creamy yellow. Stands shipping excellently. Pkt, 5c; oz, 15c; 1/4 1b, 45c; 1b, $\$ 1.35$, postpaid. Not prepaid, $5 \mathrm{Ibs}, \$ 5.50 ; 25 \mathrm{Ibs}, \$ 21.50$.

406 Golden Foney Dew. (105 davs). Similar to the Honey Dew but slightly smaller and a little earlier. The flesh is salmon tinted and can be eaten clear to the rind. It has a rich, spicy flavor, which is considered to be much more tasty than the Honey Dew. Pkt, 10c; oz, 20c; 1/4 1b, 55c; $1 \mathrm{~b}, \$ 1.60$, postpaid. Not prepaid, $5 \mathrm{lbs}, \$ 6.50 ; 25 \mathrm{lbs}, \$ 25.50$.

394 Golden Beauty Casaba. The Casaba is just coming into favor in the larger markets, where it often brings higher prices than the Honey Dew. While primarily a Winter Melon, it can be grown for the early market, where it will bring a premium. Melon grows 6 to 8 inches in diameter, and is nearly round. Flesh pure white, very thick, and of marvelous flavor. Pkt, 10c; oz, 25c; 1/4 1b, 70c; $1 \mathrm{~b}, \$ 2.00$, postpaid. Not prepaid, 5 1bs, $\$ 8.00$.

395 Roadside Market. (95 days). An exceptionally large Melon and also one of the finest flavored Melons we grow. Roadside Market has a particularly rich flavor which is quite distinctive. The Melons are almost round, frequently weigh over 10 pounds and have very thick, pink flesh. Pkt, 10c; $0 \mathrm{z}, 30 \mathrm{c} ; 1 / 4 \mathrm{~b}, 90 \mathrm{c} ; 1 \mathrm{~b}, \$ 2.50$ oz, 30c; $1 / 41 \mathrm{~b}, 90 \mathrm{i} ; 1 \mathrm{~b}, \$ 2.50$, $5 \mathrm{lbs}, \$ 11.00$.

I want more of that good Carrot Seed. I made the finest carrots from the seed you sent me that I ever made.

J. H. JONES, Brookshire, Texas.

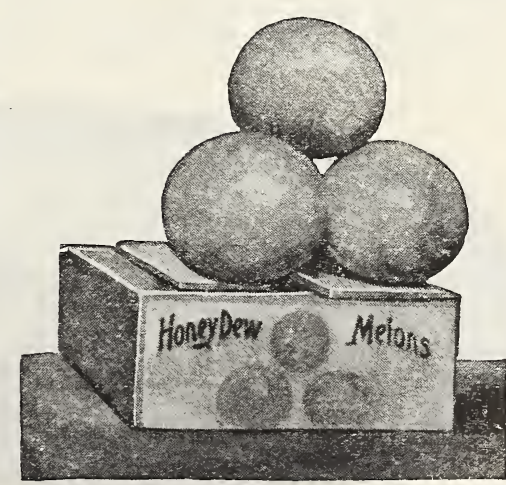




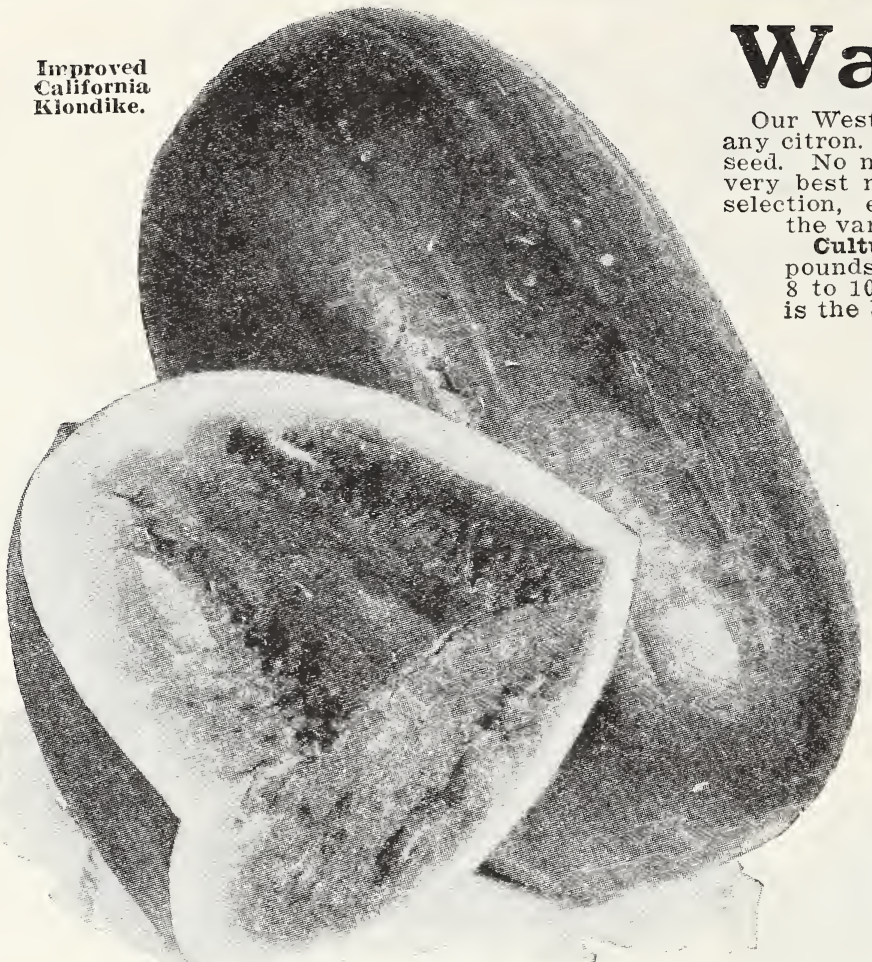

Our Western Grown Watermelon seed is free from any citron. It is grown in fields that are strictly for melons are marketed from these fields, the

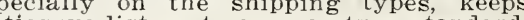
e varieties we list up to an even type standard.
culture. One ounce plants 30 hills; three ounds to the acre. Plant in well drained hills, 8 to 10 feet apart each way. A light, sandy soil best, but Watermelons do well on any soil planted between the rows in a cornfield. In growing they require plenty of water. Avoid lifting the vines and use only hand tools in cultivating.

752 Ward's Rio Grande. (75 days). An extremely early Melon and the finest, sweetest flavor of all the early Mielons. You like Watermelons; you will like them better if you can get them real early in the season; you like Watermelons with rich bright red flesh and a solid heart; you like them crisp, tender and sweet-if that is what you want in a Watermelon we know you will like the Rio Grande. It is a long Melon with a thin dark green rind; it is too tender to stand shipping but it is ideal for home markets and for your garden. We have had several Rio Grande Melons weighing over $40 \mathrm{lbs}$. It is the best early Watermelon we have ever grown. Pkt, 15c; oz, 35c; 1,4 ib, $\$ 1.00 ; 1 \mathrm{~b}, \$ 2.50$, postpaid. Not prepaid, 5 lbs, $\$ 10.00 ; 10 \mathrm{lbs}, \$ 18.75$.

751 New Mariket Early. (70 days). The earliest Watermelon grown in this country. Cole's Early, which we have now discontinued, not only matures later but is not of equal quality. New Narket Early will mature at much higher altitudes and in more northern latitudes than Kleckley Sweet. Good sized melons, slightly oval in shape. The rind is dark green, mottled with darker green stripes and the flesh is bright red. Not suitable for shipping but excellent for home gardens and nearby markets. Pkt, 10c; oz, 20c; 1/4 1b, 50c; 1b, \$1.50, postpaid. Not prepaid, 5 los, $\$ 6.00$. can be garden and one thr can be shipped moderate distances. Our seed from an excellent selection made by the University of California. The seed supply of the Improved California Klondike is very limited; when our stock is exhausted we will supply the regular Klondike on orders, unless otherwise specified. Improved California Klondike Melons are larger than Klondike, cylindrical shape, tapering toward the blossom end. The rind is dark green and fairly tough. The seeds are small and black and the flesh is an attractive bright red. Pkt, $10 \mathrm{c} ; \quad 0 z, 25 \mathrm{c} ; 1 / 41 \mathrm{~b}, 70 \mathrm{c}$ ib, \$2.00, postpaid. Not prepaid, 5 Ibs, \$8.00.

757 Falbert Honey. ( 87 days). The sweetest of all Watermelons and a home garden favorite. Grows fully as long and as big as Kleckley Sweet The Melons are dark green, slightly ridged and blunt at both ends. The flesh extends to within half an inch of the rind and is a beautiful bright crimson. It leaves no trace of pulp in the mouth. Rind too tender for ship-

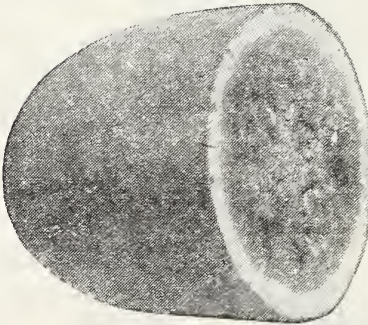

Rocky Ford Watermelon.

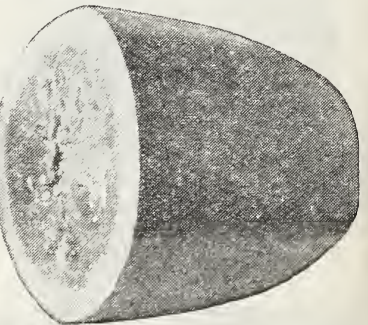

ping. Plst, 5c; 0z, 10c; 1/4 Ib, 30c; 1b, \$1.00, postpaid. Not prepaid, 5 Ibs, $\$ 4.50 ; 101 \mathrm{bs,} \$ 8.50$.

762 Rocky Ford. (80 days). A Colorado selection of the Kleckley Sweet type. This excellent selection is one of the finest to plant for home use. The good sized Melons are very attractive, oblong in form, and have a dark green, glossy skin. The rind is unusually thin, with the flesh ripening close to it. The color of the flesh is a beautiful bright scarlet, and the heart is broad and solid. Pkt, 10c; Oz, 20c; 1/4 1b, 45c;

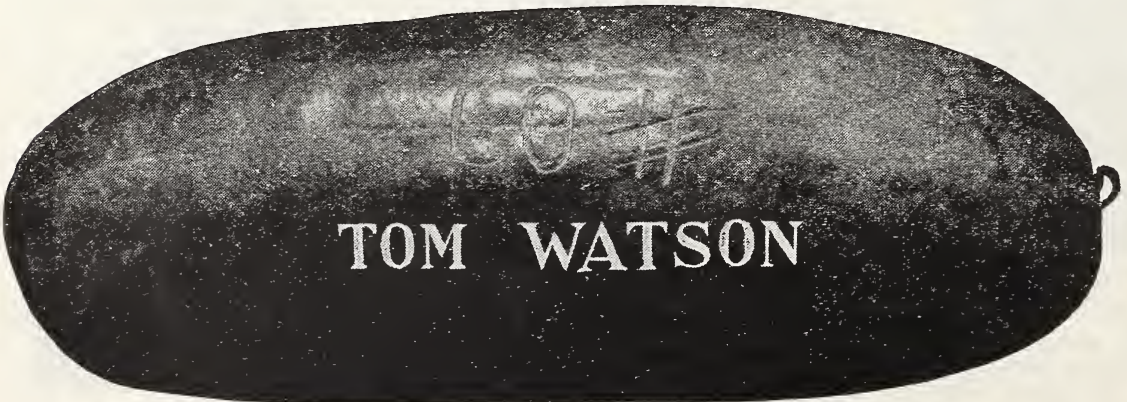
1b, \$1.25, postpaid. INct $10 \mathrm{Ibs}, \$ 9.00$.

758 Kleckley's Sweet. ( 85 days). An immensely popular home garden Melon because of its earliness, superb flavor and surpassing crispness. Flesh very bright rich red and ripens nearly to the rind. The rind is too tender for shipping. Very dark green rind. Good size, oblong form, tapering towards the stem end. Pkt, $5 \mathrm{c}$; oz, 10c; 1/4 1b, $35 \mathrm{c} ; 1 \mathrm{~b}, \$ 1.10$, postpaid. Not prepaid, 5 lbs, $\$ 4.50 ; 10168, \$ 8.00$. 
WATERMEIONS-Continued.

767 Ward's Cannonball. (90 days). A large, round Melon, with solid meat, practically all heart. While not the earliest Melon, our triai grounds manager says that after he gets the first Cannonballs he will eat no other Melon, for the flavor is the very finest. This Watermelon is very well known in the Grand River Valley but we could not obtain enough of this until 1925. When better known, no farm garden will be complete no farm garden will be complete
without this Melon. The rind is only about half an inch thick but the flesh is so solid that it will stand a limited amount of shipping. 'This is the variety we recommend to you for your main crop. Plkt, 10c; oz, 20c; $1 / 41 \mathrm{~b}, 40 \mathrm{c} ; 1 \mathrm{~b}$,

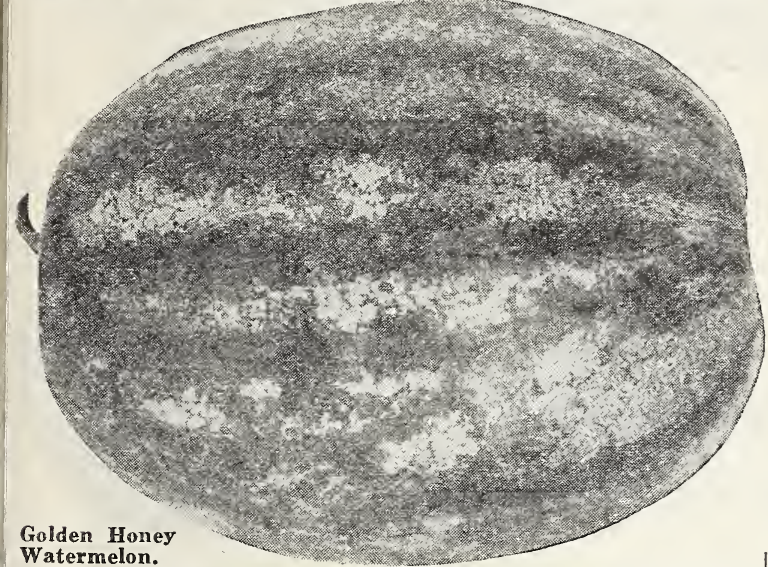

Watermelon.

765 winter Queen. (95 days). Watermelons for Christmas. Nearly round, nearly white; ripen early but will remain solid and of good quality for two or three months. Every one should raise a few. Pkt, 5c; $0 \mathrm{z}, 15 \mathrm{c} ; 1 / 41 \mathrm{~b}, 45 \mathrm{c} ; 1 \mathrm{~b}, \$ 1.40$, postpaid.

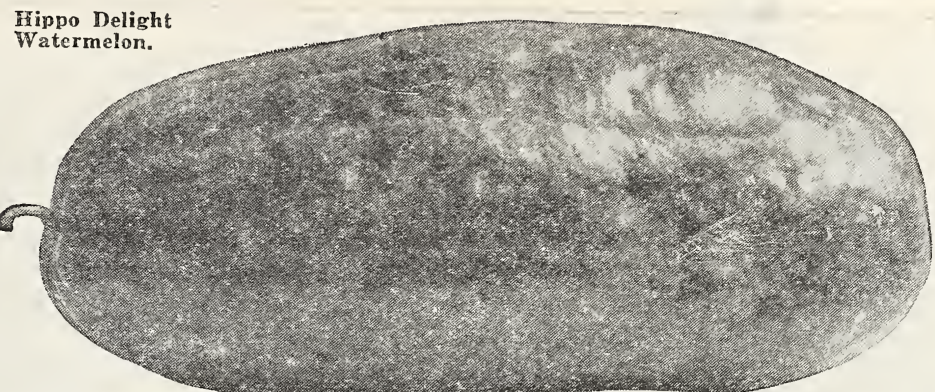

764 Tom Watson. (95 days). Still the most popular of all shipping Melons. The flesh is firm and always an intensely dark red color. The rini is deep green, indistinctly veined, thin but hard and tough, allowing long-distance shippingt. Melons average 40 pounds and are cylindrical in shape. Pkt, 5c; oz, 10c; 1/4 1b, 25c; 1b, 75c, postpaid. Irot prepaid, 5 Ibs, $\$ 3.40 ; 10 \mathrm{lbs}, \$ 6.25$.

766 Irish Gray. (95 days). New shipping Melon. The toush rind withstands long shipping and helps the Melon to keep well. Attractive greenish grey skin but more attractive red, firm sweet flesh notably free from hard centers and stringiness. Weight about 30 pounds. Pkt, 5c; oz, 10c; $1 / 41 \mathrm{~b}, 35 \mathrm{c} ; 1 \mathrm{~b}, \$ 1.00$, postpaiā. Not prepaid, 5 lbs, $\$ 4.25$; $10 \mathrm{lbs}, \$ 7.50$.

768 Fippo Delight. (95 days). A new Watermelon of excellent flavor and enormous size. Hippo rind is quite tough and will stand long-distance shipping. The solid flesh is dark red and a fine sweet flavor. On the market the size of Hippo Delight creates the sale. The Melons are long with a fairly thick, dark green rind with very faint stripes. Pkt, 15c; oz, 35c; 1/4 1b, $\$ 1.00$; $1 \mathrm{~b}, \$ 3.00$, postpaid. Not prepaid, $51 \mathrm{bs}, \$ 11.75$.

756 Golden Foney. (90 days). One of the best eating Melons, has a fine sweet flavor. The golden colored flesh is very tender, entirely free from hard centers or stringiness. Oval melons, weight 25 pounds. Not a shipper but a quality home garden Melon. Pkt, 10c; oz, 20c; 1/4 1b, $45 c ; 1 b, \$ 1.25$, postpaio.

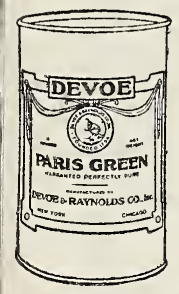

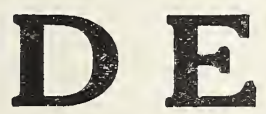

Insecticides

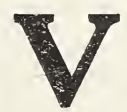

$\therefore$

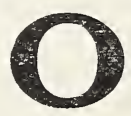

Fungicides

\section{Manufactured by Devoe \& Raynolds Co., Inc. Chicago, III.}

The Devoe complete line of Arsenical Insecticides and Fungicides offers the grower protection against practically every type of insect and blight. Flowers-plants-vegetables - trees and shrubbery that are planted and fertilized with infinite care should be given a chance for real life and growth by being given proper protection against such parasites.

A Devoe Spray Calendar will tell you in detail exactly what should be done for this protection, also how and when to do it; ask for one. Prices not prepaid; send postage if items, not poisons, are wanted by mail. Poisons cannot be mailed. Case lot prices subject to revisions. Write for later prices.

Devoe Paris Green (America's Standard of Quality for three generations). 1/4 1b., 20c; 1 1b., 65c; case (2.4 1-1b. cartons), \$12.50.

Devoe Arsenate of Iread, 1 1b., 40c; 4 lbs., \$1.00; case (8 4-1b. bags). Write for qrotation. Devoe Calcium Arsenate, 1 lb., 30c; 4 Ibs., 85c; case (8 4-1b. bags). Write for quotation.

Devoe Arsenite of Zinc, 4 lbs., $\$ 1.00$; case $(8$ 4-1b. bags), \$6.25. (Use Arse-

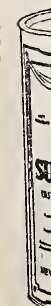
Devoe Arsenite of Zinc, 4 lbs., $\$ 1.00$; ca
ite of Zinc for Mexican Be'an Beetles).

Devoe Bordeaux Mixture, 1 1b., 40c; 4 lbs., $\$ 1.00$; case (8 4-1b. bags). Write for quotation.

Dry Iime and Sulphur, 1 Ib., 40c; 5 lbs., \$1.70; 100-1b. drums. Write for quotation.

\section{AND ITW INTERESTING SPECIALTIES}

"Sure Noxem"-A Ready-to-use Dry Powdered Insecticide and Fungicidein sifter-top cans for the housewife-gardener-greenhouse operator-fruit grower. 1-1b. carton, $25 \mathrm{c}$.

Double Duty Spray-A Dry Powdered, carefully combined mixture of Devoe Arsenate of Lead and Bordeaux Mixture. Unsurpassed as a combination insecticide and fungicide. 1 1b., 50c; 4 lbs., $\$ 1.40$.

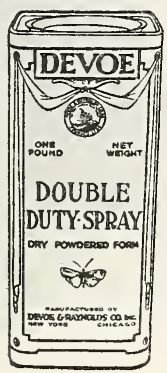




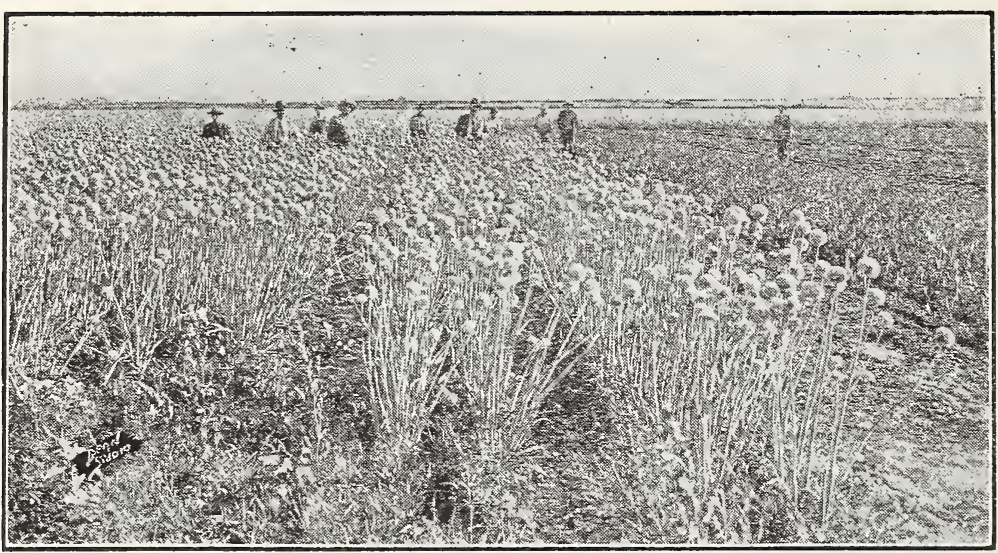

One of Our Mountain Danyers Seed Fields.

enough to gain exceptional early maturity and long keeping qualities are the Mountain Red Globe, Mountain Sweet Spanish and Mountain Yellow Globe.

All our bulbs are grown from our selected stock seed, the bulbs are sorted and stored over Winter. The bulbs are ther re-sorted and set out in the Spring to grow to seed. This method assures all varieties being true to color and type and free from any thick necks or Onions that will not keep properly.

Continued mountain growing of all varieties gains earlier maturity better keeping qualities, a deeper colored skin, an $\in v e n$ thin-necked type and increased size and yield.

Culture. One ounce to 200 feet of drill; 3 to 6 pounds per acre. Soil for Onions should be well drained, very rich or fertilized, well pulverized at the surface and above all free from weeds. In weedy soil the work of weeding the Onions will be more than the crop is worth. Sow the seed thinly in drills onehalf inch deep and rows 14 inches apart. Keep the ground open and free from weeds but do not ridge up to the growing bulbs.

FAII SOWING. We recommend sowing a part of your acreage the middle to latter part of August. Some of these Onions will go to seed in the Spring and a few will winter-kill, but the high price obtained for the early crop will offset the loss. Part of this loss can be overcome by sowing the seed slightly thicker than Spring planting.

554 Mountain Danvers. (95 days). The earliest and best keeping yellow globe onion. Popular in all northern onion sections. Yields an enormous crop,

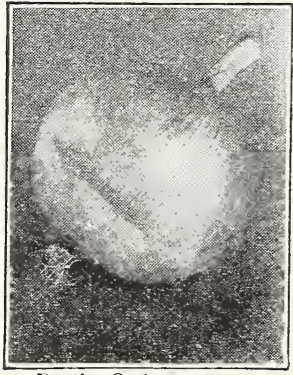

Denia Onion.

growing 300 to 700 sacks to the acre in our irrigated mountain valleys. The Mountain Danvers is the result of 30 years growing in the mountains of Western Colorado. Originally the seed was grown, and some seed still is grown by Western Colorado farmers for their own use. Each farmer had a different idea of the type he required with the result that there has been a wide variation in the type of this variety. All types have been very early and excellent keepers. During the past few years we have selected the Mountain Danvers on our "Mile High" farms and have bred it to an even type. Our Mountain Danvers is apple shaped, that is, a very slightly flattened globe. The onions are thin-necked and solid The skin is a darker color than the Yellow Globe Danvers and the Mountain Danvers matures a month earlier. The Mountain Danvers is a good size, the crop ripens evenly and will keep with less shrinkage or loss than any other Onion, with the possible exception of the Australian Brown. Plrt, 10c; 0z, 40c; 1/4 1b, \$1.20; 1b, \$3.55, postpaia. Not prepaid, $5 \mathrm{lbs}, \$ 16.25 ; 10 \mathrm{lbs}, \$ 30.50$.

574 Mountain Yellow Globe. (110 days). A companion type to the Mountain Danvers, not quite as early, but a deeper bulb, being a true ball-shaped globe. Originally
from the Southport Yellow Globe type, continued mountain grow-

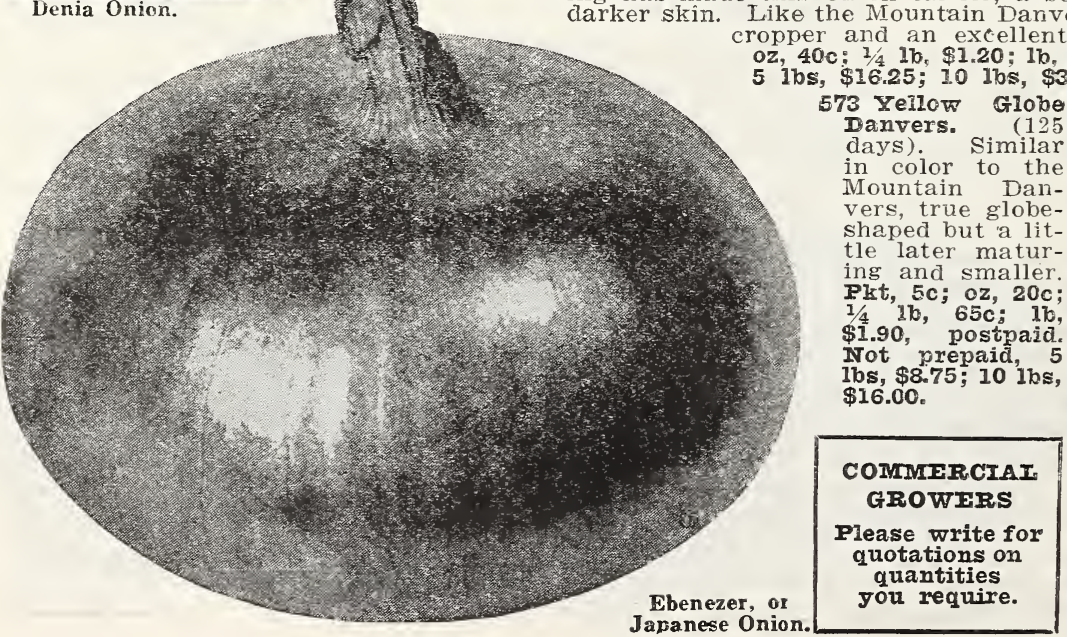
better keeper and a somewhat darter srine this Onion eartier, a beter his Onion is an immense ropper and an excellent market variety. Pkt, 10c; 2, 40c: $1 / 41 \mathrm{~b}, \$ 1.20 ; 1 \mathrm{~b}, \$ 3.55$, postpaid. Not prepaid, 573 Xellow Globe Danvers. (125 in color to the Mountain Daners, true globeed a little later maturPkt, 5c; oz, 20c; $1 \mathrm{t}, 65 \mathrm{c}$; $1 \mathrm{~b}$, Tot postpaid. bs, $\$ 8.75 ; 101 \mathrm{bs}$, $\$ 16.00$.

\section{COMMIFRCIAI}

lease write for uotations on you require.

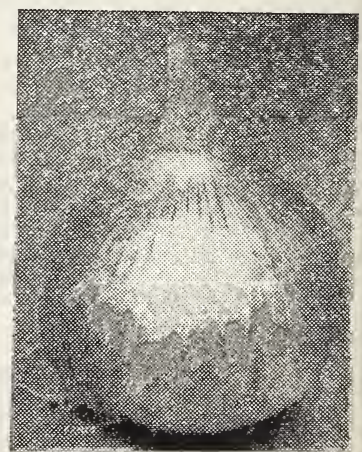

Yellow Globe Danvers. 


\section{OrIONS-Continued.}

558 Ebenezer or Japanese. (110 days). Mild in flavor, early in maturity and an excellent keeper. In great demand for Onion sets as it ripens down early and the sets keep well. Also in turn the sets are in great demand, for they make an early mature Onion for market. They are much better yielders than somewhat flattened. The Ebenezer seed will always be scarce, as the variety is a poor seeder. Pkt, 10c; oz, $30 \mathrm{c}$; $1 / 4$ 1b, 90c; 1b, \$2.75, postpaid. Not prepaid, 5 lbs, \$12.00; $1 / 4$ 1b, 1022.50 .

560 Southport Yellow Globe. (130 days). A handsome market variety. Medium to large size, true globe shape with a deep yellow skin. Pkt, $10 \mathrm{c} ; \mathrm{oz}, 25 \mathrm{c} ; 1 / 4 \mathrm{lb}, 70 \mathrm{c} ; 1 \mathrm{~b}, \$ 2.00$, postpaid. Not prepaid, $5 \mathrm{lbs}, \$ 8.75$; 10 lbs, \$16.00.

557 Prizetaker. (135 days). The original Sweet Spanish type. A large, globe-shaped Onion with a straw colored skin. Good for Fail use but not a good keeper. Very similar to Gigantic Gibraltar. Plt, 10c; oz, 25c; 1/4 1b, 70c; Ib, $\$ 2.00$, postpaid. Not prepaid, $5 \mathrm{lbs}$, $\$ 8.50 ; 10 \mathrm{lbs}$, $\$ 15.75$.

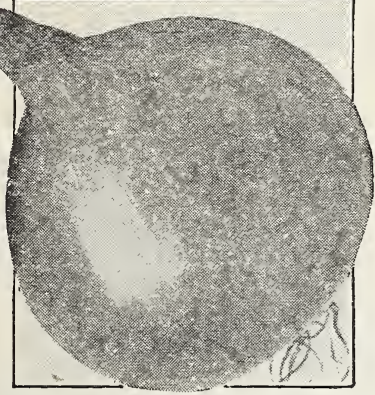

Southport Yellow Globe.

571 Mountain Red Globe. (100 days). A worthy companion to the Mountain Danvers. By most careful selection from the Southport Red Globe we produced the Mountain Red Globe. The many compliments we have received on this Onion prove it to be a real success. Mountain Red Globe is true globe shaped, thinnecked, solid flesh, early maturing and enormously productive. By all standards the finest Red Onion grown. Tot prepaid, 5 los, 570 Denia. improved Prizetaker, somewhat larger and a considerably better keeper. Pkt, 10c; oz, 25c; $1 / 41 \mathrm{~b}, 75 \mathrm{c} ; 1 \mathrm{~b}, \$ 2.25$, post p9.00; $10 \mathrm{lbs}, \$ 17.25$.

559 Mountain Sweet Span-

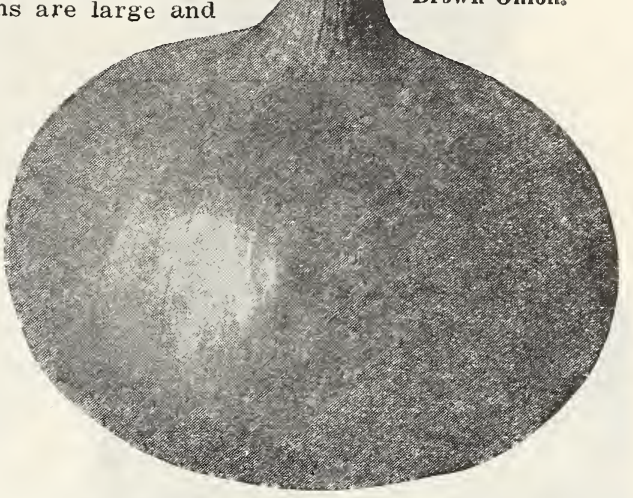

ish. (120 days). The finest, largest and best keeping of the Sweet Spanish types. Mountain Sweet Spanish is the result of continued mountain growing of the Riverside Sweet Spanish. An excellent variety for shipping or storing for Winter use. The Onions are large globes, averaging 6 inches in diameter, and yield an enormous crop per acre. The flavor is sweet and mild. Plkt, 15c; oz, 50c; 1/4 1b, \$1.50; 1b, \$4.75, postpaid. Not prepaid, 5 Ibs, \$21.25; 10 1bs, \$38.75.

556 Australian Brown. (110 days). Excellent keeper, medium size, flattened globe with a dark brown skin, good set variety. Pkt, 5c; oz, 20c; 1/4 1b, 55c; 1b, \$1.65, postpaid. Sot prepaid, 5 lbs, $\$ 7.25$.

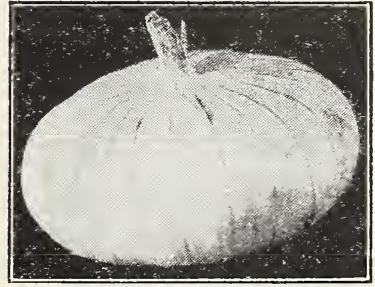

White Portugal.

(P)

569 White Iisbon. For green Onions; early, yet slow to form a bulb. Pkt, 10c; $0 \mathrm{z}, 20 \mathrm{c} ; 1 / 4 \mathrm{lb}, 65 \mathrm{c} ; 1 \mathrm{~b}, \$ 2.00$, postpaid. Fot prepaid, $5 \mathrm{lbs}, \$ 8.50$.

565 Mrammoth Silver $\mathrm{king}$. (115 days). Large, flat, white variety, used only for Fall market. Pkt, 10c; oz, 20c; 1/4 1b, 65c; 1b, \$2.00, postpaid. №t prepaid, $5 \mathrm{lbs}, \$ 9.50$.

563 Fxtra Early White Pearl. (90 days). The earliest and finest of the pickling Onions. Small, round, hard, crisp and tender. Pearly white flesh, mild and sweet flavor. Pkt, 10c; 0z, 35c; $1 / 4 \mathrm{lb}, \$ 1.00 ; 1 \mathrm{~b}, \$ 3.00$, postpaid. Not prepaid, 5 los, $\$ 12.00$.

568 Early White Queen. (95 days). The little round, white Onion used for pick-

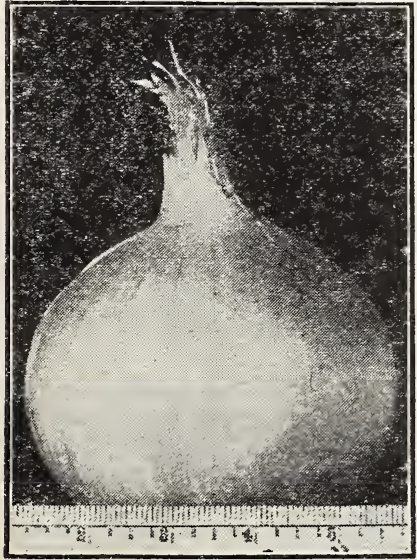

Mountain Sweet Spanish ling or in chow-chow flesh and mild in flavor. Pickled Onions are enjoyed by all the family. To grow for pickling, sow seed thickly (1 oz. to $50 \mathrm{ft}$. of drill), cover well and do not allow the on. ions to appear above ground. This variety is also well adapted for early bunch Onions. Pkt, 10c; oz, 30c; 1/4 lb, 90c; lb, $\$ 2.75$, postpaid. Not prepaid, 5 lbs, $\$ 11.00$.

566 Crystal White wax. (120 days). Pure white, early, extremely mild and sweet. Crystal Wax is usually grown from plants and then matures for a Summer salad Onion when it commands a good market price. Good sized, very flat bulbs. Crystal Wrax must be cured in the shade or they will sunburn and spoil very quickly. Can be grown for Summer use from seed planted in the early Fall. Teneriffe grown seed. Pkt, 10c; oz, 40c; 1/4 1b, \$1.15; 1b, \$3.50, postpaid. Not prepaid, 5 lbs, $\$ 15.00$.

564 Yellow or White Bermuda. (120 days). Similar to Crystal Wax but with a straw colored skin. Yellow Bermuda is a deeper Onion, a better vielder and not so liable to sunburn. Teneriffe grown seed. Plt, 10c: oz, 35c; $1 / 41 \mathrm{lb}, \$ 1.05$; 1b, $\$ 3.15$, postpaid. Not prepaid, 5 lbs, $\$ 12.50$.

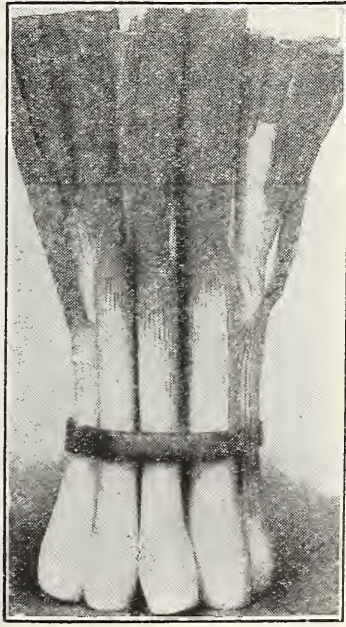

White Lisbon Onions. 


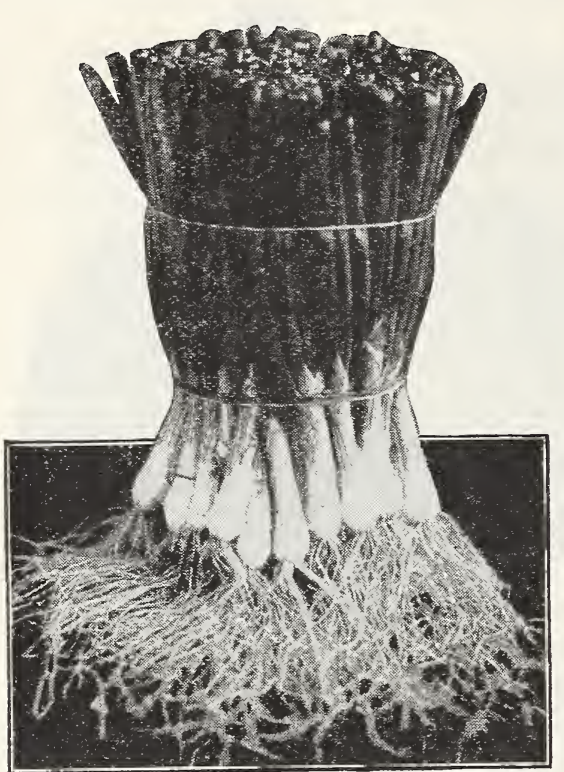

Crystal Wax Onion Plants.

\section{Onion Plants}

Onion plants produce the fine, sweet salad Onions for Summer use. These Onions are grown from plants muen earlier than they could be grown from seed.

The Onion plant is a small green Onion with the root on, well started, and grown from the finest varieties of Onion seed.

The live, green, well rooted, vigorous Onion plants are ready to go to work as soon as they are set in the field or garden.

Mountain Grown Onion Plants. These exceptionally hardy plants are grown outdoors in the mountains without any
protection. The seed is sown in the ear

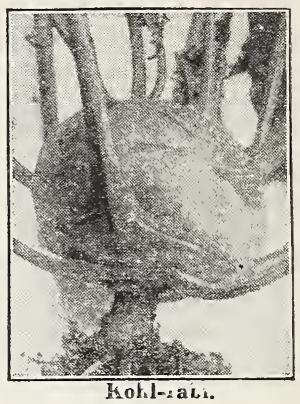
protection. The seed is sown in the early Fall and while some winter kill, the plants which survive are really hardy and will grow in spite of adverse weather. These plants are pulled at our farms and shipped to you fresh from the field. Some of our customers in the southern states require their Onion plants before our ground thaws, oll these early orders we ship Texas grown plants. They are grown for us from our selected seed.

About 90,000 plants are required to set an acre. A good yield is 7 to 10 bushels of Onions per 1000 plants. Onion plants are very hardy and can be set out as soon as the ground can be worked in the Spring. This will give you fine quality Onions for the early market or table. Onion plants are not easily perishable if kept dry and not allowed to heat.

Crystal wax. The most popular variety of Onions grown from

plants, Skin pure white and very thin. Flesh very mild and

sweet. Brings a premium on the market. $30 \mathrm{c}$ per 100; $\$ 1.00$ per $500 ; \$ 1.80$ per $1000 ; \$ 7.00$ per crate of 6000 ; quantities of 18,000 plants or over, $\$ 1.10$ per 1000 , prepaid.

Yellow or white Bermuda. Fine sweet flavor and a heavy yielder. $30 \mathrm{c}$ per $100 ; 95 \mathrm{c}$ per $500 ; \$ 1.70$ per 1000 ; $\$ 6.50$ per crate of 6000 ; order of 18,000 plants parcel post.

\section{Onion Sets}

Our Onion Sets are all Colorado grown and a fine solid quality which is far superior to the sets grown in many sections. Mountain growing produces the solid quality and mountain sunshine cures them into excellent keeping Onion sets. They are stored during the winter on ventilated trays to be in fint.

While many of our customers will use Onion plants for growing their largé Onions, Onion sets will be still found in all gardens for early green Onions.

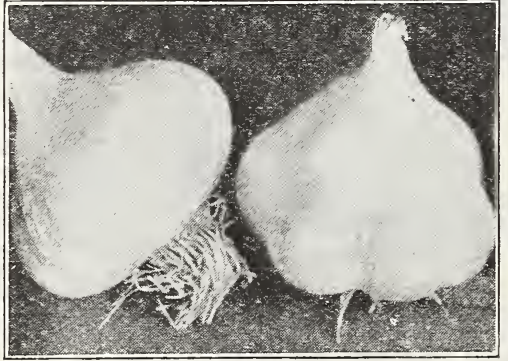

Garlic Bulbs.
Molantain Sweet Spanish. Large, sweet globe Onions, early and good keepers. 40c per 100; $\$ 1.10$ per 500 ; $\$ 2.00$ per 1000; $\$ 8.00$ per crate of 6000 plants; order of 18,000 plants or over, $\$ 1.25$ per 1000 , by prepaid express or parcel post.

\section{Garlic}

Grown from bulbs only, divide bulbs in planting. Used for fla-

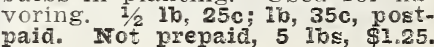

\section{Kohlrabi}

Sometimes called the Lazy Man's Cauliflower, being cooked and served in the same mannel as cauliflower. The bulbs should be gathered to be tender as soon as they are $1 \frac{1}{2}$ to 2 inches in diameter. Successive plantings should be made to insure a steady supply. One ounce will sow 300 feet of drill.
Mountain Danvers. Qt. 25c; 4 Ibs, 85c, postpaid. Yellow Onion Sets. Qt, 25c; 4 lbs, 75c, postpaid. White Onion Sets. Qt. 25c; $4 \mathrm{lbs}, 85 \mathrm{c}$, postpaid. Red Onion Sets. Qt. 25c; 4 Ibs, 75c, postpaid. see colored price sheet for prices on larger quantities.

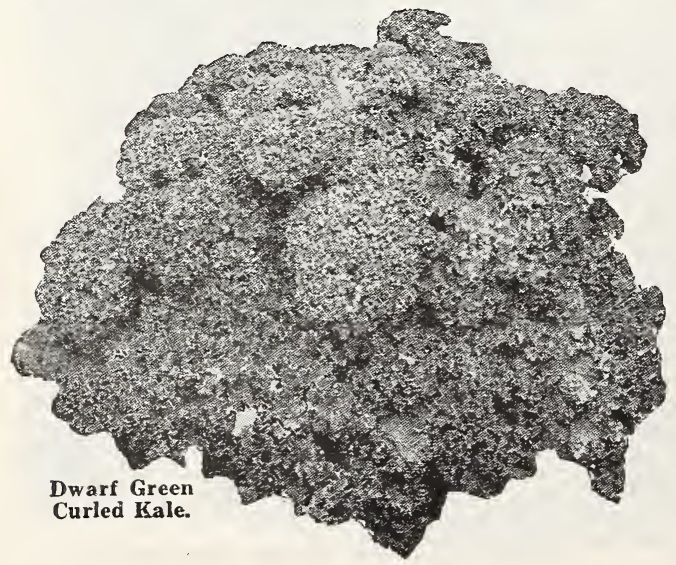

522 Early White Vienna (50 days). Extremely early, with distinctly small tops; bulbs medium size, very light green or nearly white and of the best quality. Flt, 10c; oz, 20c; 1/4 1b, 60c; 1b, $\$ 1.75$, postpaid. Irot prepaid, $5 \mathrm{los}, \$ 7.50$.

\section{Kale or Borecole}

Culture. One ounce produces 2500 plants. Kale furnishes excellent greens for Winter and early spring use, with a flavor entirely different. Sow late, frost improves the quality. Transplant to $21 / 2$ feet apart. Excellent for cooking with meat and soups. Also used for green feed for chickens.

520 Dwarf Green Curled. (55 days). The leaves resemble handsome, thick plumes. 12 to 14 inches long. Flet, 5c; oz, 15c; 1b, 35c;110, 95c, postpaid. Not prepaiá, $5168, \$ 3.50$.

\section{Leek}

A delicately flavored member of the onion famiiy, equally useful for flavoring soups or as a salad.

Culture. One ounce to 150 feet of drill. Sow as early as possible in Spring, or can be started in hotbeds. In cultivating hill up to the plants. Plants are hardy and may be left outdoors all Winter.

524 Iarge American rlag. (90 days). An early, hardy variety. Plkt, $5 \mathrm{c} ; \mathrm{cz}, 15 \mathrm{c} ; 1 / 41 \mathrm{~b}, 45 \mathrm{c} ; 1 \mathrm{~b}, \$ 1.50$, postpaid. Not prepaid, 5 It: $\$ 6.50$. 


\section{Mustard for Greens}

One ounce to 600 feet of drill.

Sow the seed every ten days during cool weather. Water freely.

547 Giant Southexn. Curled. (50 days). Very harảy, true curled leaf variety, popular in the South for postpaid. Not prepaid, 5 lbs, \$2.70; 25 lbs, \$10.75.

550 Chinese Broad Ieaf. (55 days). Leaves twice the size of other varieties; stems more succulent, deep green; very pleasing, sweet, pungent flavor. Pkt, 5c; oz, 10c; 1/4 1b, 30c; 1b, 90c, postpaid. Not prepaid, 5 lbs., $\$ 3.60 ; 25$ 1losa, $\$ 22.75$.

\section{Okra or Gumbo}

This vegetable does not take up much room in the garden and is really a highly prized seasoning for stews, meats and soups. Also used for pickles, or dried for Winter use. Cultivate the same as corn. In the higher altitudes the seed should be started indoors in

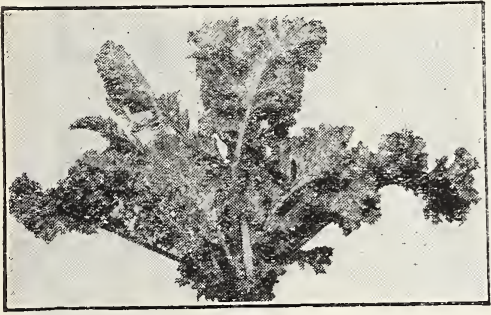

Giant Southern Curled Mrustard,

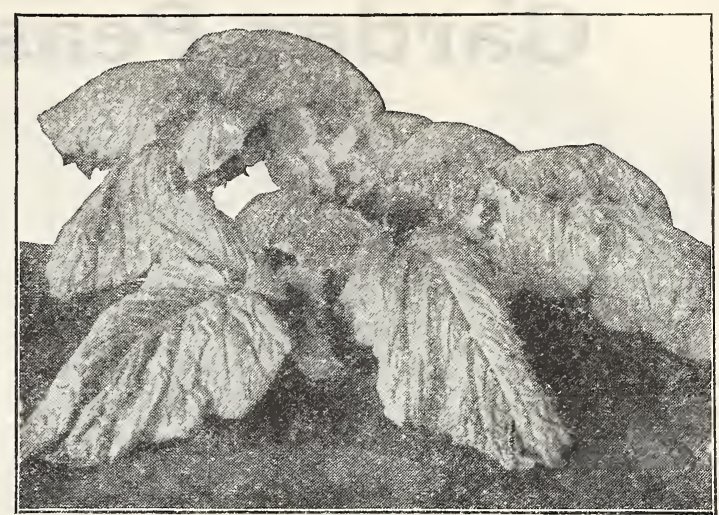

Chinese Broad Leaf Mustard. paper pots. One ounce sows 75 feet of row.

552 White Velvet. (70 days). An early variety producing long, smooth, white pods of excellent fiavor. Pkt, 10c; oz, 15e; $1 / 4$ 1b, 25c;1b, 70c, postpaid. Iy prepaid, $51 \mathrm{bs}, \$ 2.50$.

553 Perkins Fong Pod. (75 days). Long. deep green pods of fine quality. Extersively grown in the South for market and home garden. Plants grow very tall and produce a great abundance of pods 5 to 10 inches in length. Pkt., 5c; oz., 10c; $1 / 41 \mathrm{~b} ., 20 \mathrm{c} ; 1 \mathrm{~b} ., 60 \mathrm{c}$, nostpaid. Not prepaid, 5 1bs., \$2.20.

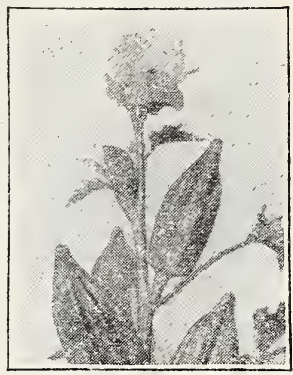

Okra.

\section{"Friend" Sprayers}

\section{For All Purposes}

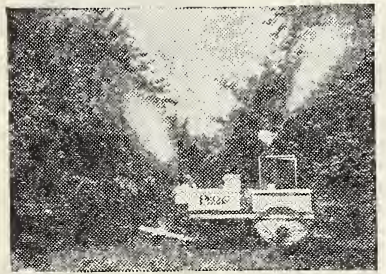

Successful vegetable growers have found through years of experience that it is absolutely essential to spray thoroughly and consistently, if the most gratifying results are to be obtained. For economical and highly efficient spraying the "Friend" traction sprayer is without equal.

"Friend" builds a large number of sprayers for all kinds of work, large, medium and small: stationary sprayers for piped installation up to 100 gallon per minute capacity; full roller

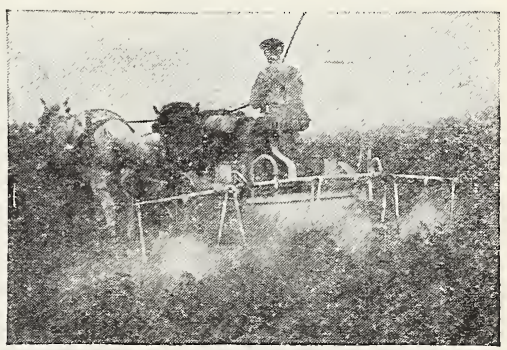

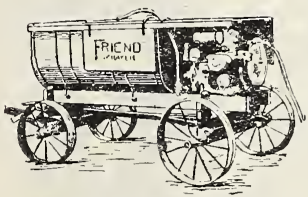

Bed Type sprayers

These are made large, medium, small. Furnished on bed to be used on farm wagon. Fquipped with "Friend" high pressure motor-pumps.

\section{GRAND JUNCTIDE SEED CO.,}

Grand Junction.

PAIMIR \& JOEIYN, Cedaredge, Colo.

BONNEII IMP. CO., Ioveland, Colo. sprayers ar t tractoi driven; for all kinds of work, large, medium and small; special tractor drawn sprayers.

No matter what your sprayer problem is, you will do 'l to let "Friend" engineers offer their suggestions.

There is a "Friend" agent in your district. Write for name of nearest dealer.

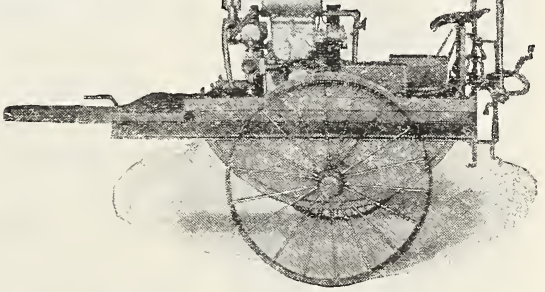

PHEIGAR BROZLTIRAE CO. Dolores, Colo.

\section{MOODY-WARRIET} COMML, CO.

Fort Collins, Colo. (Colorado Dealers)
"The "Friend" Combination Potato, Field, Orchard and Vegetable Sprayer.

\section{Friend Manufacturing Co:}

\section{Gasport, New York State}




\section{Garden Peas (Mountain Grown)}

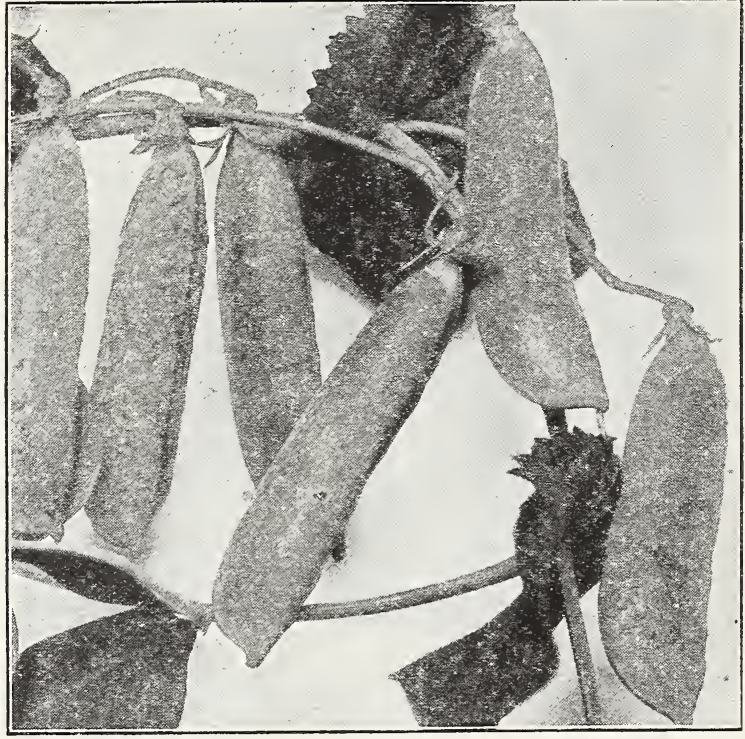

Alaska Peas.

The finest flavored Peas can only be from the home garden. Peas should be cooked within a few hours after picking to maintain their full flavor.

Peas are well adapted to a commercial crop as they are very seasonal. They are naturally a cool weather crop. Peas can be grown in the spring and Fall in most places. In the Winter they are grown in the southern shipping sections. In midsummer we get the wonderful dark colored, high flavored Peas from the higher mountain valleys. The dark color and rich flavor are bred into the Peas by continued mountain growing. "Mile High", Seed Peas are grown at altitudes of 7,000 to 8,000 feet Peas are one important crop that should always be raised from Mountain Grown Seed.

Culture. One pound will plant 60 feet of single row; 100 to 150 pounds for an acre. A light soil is best for the early varieties, a heavier soil that will retain moisture for the main crop. Well-rotted manure may be used to enrich the soil. Peas are a cool weather crop. Plant the early smooth varieties, Alaska and Pedigree Extra Early, as soon as the ground can be worked. The wrinkled varieties, if planted early, should be in a light soil and not over an inch deep. Make main crop planting 3 to 4 inches deep. Peas are usually planted in double rows, 6 inches between rows and 2 to 3 inches between seeds. Plantings should be made every two weeks until hot weather. An excellent crop can be raised by planting in the late Summer to mature before frost Peas require plenty of moisture, a good vine growth early will shade the ground and retain the moisture to grow the crop. For canning Peas should be taken fresh from the garden and canned immediately.

585 Alaska. (50 days). The earliest of all garden Peas, can be planted early without danger of the seed rotting, and will quickly mature. Very uniform in maturity, one picking will clean the crop, and they are all used before the wrinkled varieties mature. Alaska gives you the first Peas which are always appreciated in the home garden and which sell for the best prices on the markets. One of the best varieties for canning. Smooth, blue seeds. Light green vines, $2 \frac{1}{2}$ feet high. Pods $21 / 2$ inches long, straight and square ended. Six light green peas to the pod. Pkt, 5c; $1 / 21 b, 20 c ; 10,30 c$, postpaid. INot prepaid, $5 \mathrm{lbs}, \$ 1.25 ; 25 \mathrm{lbs}, \$ 4.25 ; 100 \mathrm{lbs}, \$ 15.00$.

586 Fedigreed Extra Early or First and Best. (55 days). A larger pod and slightly more prolific than Alaska. Pedigree Extra Early has a smooth white seed and can be planted early without danger of rotting. Similar to Alaska, vines $21 / 2$ feet high, pods $21 / 2$ inches long. Fkt, $5 \mathrm{c} ; 1 / 2 \mathrm{lb}, 25 \mathrm{c} ; 1 \mathrm{~b}, 35 \mathrm{c}$, postpaid. Not prepaid, 5 1bs, $\$ 1.40 ; 251 \mathrm{bs}, \$ 5.00$, $100 \mathrm{lbs}, \$ 16.00$.

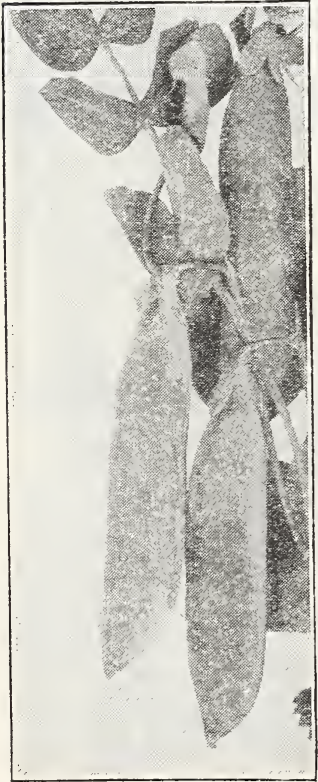

American Wonder Peas.
590 American wonder. (65 days). One of the earliest wrinkled varietjes. The wrinkled types have a finer flavor than the smooth-seeded types. The vines only grow about 10 inches high and do not require staking. Pods about $2 \frac{1}{2}$ inches long, are well filled with 6 to 8 large peas. American Wonder does exceptionally $w \in l l$ under good cultivation. Pkt, 5c; $2 / 2$ 1b, 25c; ib, 35c, postpaid. Not prepaid, 5 lbs, $\$ 1.30 ; 25$ Ibs, $\$ 4.50$; $1001 \mathrm{bs}, \$ 16.00$.

695 Nott's Excelsior. (70 days). A better yielder than American W'onder Popular for home garden because of its sturdy, compact growth. Vines about 1 foot high, carry an abundance of pods. Iight green pods 3 inches long, round, straight and blunt-ended containing 6 good sized, tender and fine flavored peas. Plat, 10c; $1 / 2$ 1b, 25c; 1b, 35c, postpaid. Not prepaid, 5 ibs, $\$ 1.30 ; 251 \mathrm{bs} ; \$ 4.50 ; 1001 \mathrm{bs}, \$ 16.00$.

596 Feter Pan. ( 75 days). The sweetest of all the large podded Peas and a favorite with so many of our customers. The fine flavor is enough to recommend this variety and it also has the large pods of the Laxtonian types. Deep green pods 4 inches long, very broad, straight and pointed, contain 6 to 8 very large deep green peas of the finest flavor. Stout, deep green vines 15 inches high. Pirt, 10c; 1/2 1b, 30c; 1b, 45c, postpaid. rot prepaid, 5 Ibs, $\$ 1.75 ; 25$ Ibs, $\$ 6.00 ; 1001 \mathrm{bs}, \$ 19.00$.

\section{Vigoro Fertilizer}

Successful gardening depends on proper feeding. Vigoro is a complete, scientifically balanced plantfood that furnishes all the different elements plants require.

Two million users have proved its success on lawns, flowers, gardens, shrubs and trees. Include a bag with your order. $5110 \mathrm{~s}, 60 \mathrm{c} ; 25$ $2 \mathrm{bs}, \$ 2.00 ; 50 \mathrm{lbs}, \$ 3.75 ; 100 \mathrm{lbs}, \$ 6.00$, not prepaid.

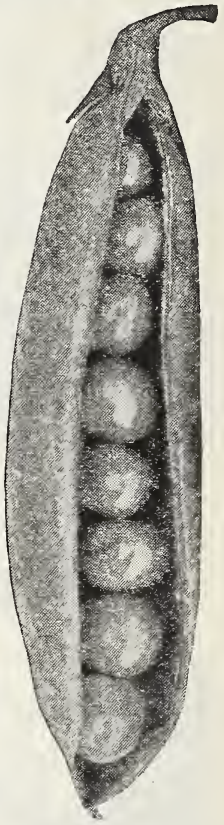

Nott's Excelsice Peas.

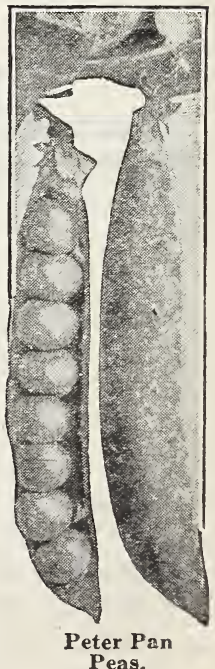




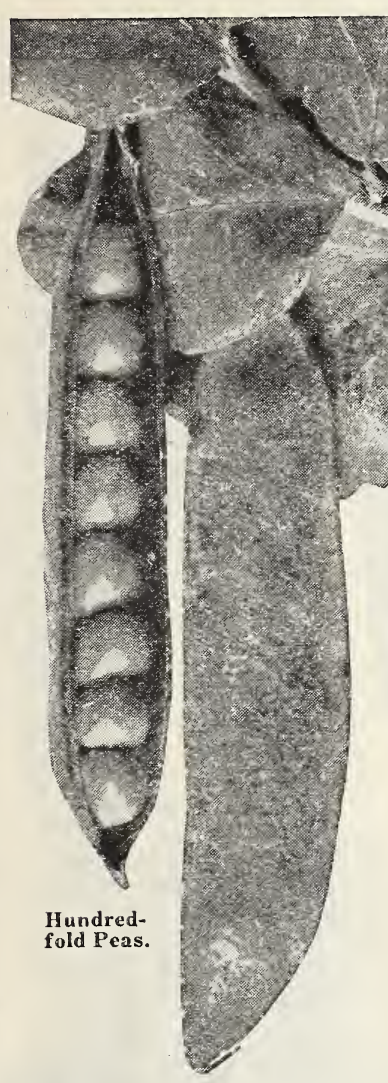

588 Fundredfold. ( 75 days). One of the best of the Laxtonian type, slightly larger pods than Peter. Pan and with very mucl of the Peter Pan flavor. Bunchy vines are well loaded with pods. Vines 16 inches high, sturdy and resist heat well. Dark green pods 4 inches long, fairly broad and pointed. Pods contain 8 large, dark green peas. Pkt, 10c; $1 / 21 \mathrm{~b}, 25 \mathrm{c} ; 1 \mathrm{~b}, 40 \mathrm{c}$, postpaid. Not prepaid, 5 lbs. $\$ 1.60 ; 25$ 1bs, $\$ 5.50 ; 100$ Ibs, \$17.50.

598 Ward's Bestever. (70 days). The best variety of the Gradus type and has been very popular ever since we introduced it in 1924. It is so hardy that it can be planted much earlier than Gradus and can be picked several days before that variety is ready. The large pods are more even in size, very attractive in appearance, and usually contain 9 dark green peas of extra fine quality. Bestever is more dwarf than Gradus, the sturdy vines growing feet high. Bestever has such a fine flavor that many of our customers nlant it in succession for early, second early, and main crop Peas. Pods 4 inches long very broad. nointed and well filled pointed 10c; $1 / 2$ 1b, 30c; 1b. $50 \mathrm{c}$, postpaid. Not prepaid, 5 lbs, $\$ 1.75 ; 25$ lbs, $\$ 6.00 ; 100 \mathrm{ibs}, \$ 21.25$.

\section{GARDEN PEAS-Continued.}

589 Irittle Marvel. (68 days). Remains in prime picking condition a week longer than Nott's Excelsior, making it a favorite with home gardeners and market gardeners. Considered the best of its class. An early, productive, wrinkled variety. Foliage and pods dark green. Pods 3 inches long, round with square end, and often contain 7 rich, dark green peas. Height 14 inches. Pkt, $10 \mathrm{c} ; 1 / 2 \mathrm{~b}, 25 \mathrm{c} ; 1 \mathrm{~b}, 35 \mathrm{c}$, postpaid. INot prepaid, 5 lbs, $\$ 1.50$; $25 \mathrm{lbs}, \$ 5.25$; $100 \mathrm{lbs}, \$ 19.00$.

594 Premium Gem. (75 days). Very productive, being an improved and more dwarf strain of McLean's Little Gem. Light green pods 3 inches long, round and square-ended, and crowded with 6 to 9 peas of delicious flavor. Not so upright as American Wonder, but the vines which grow 18 inches high, require no staking. Pkt, 10c; $1 / 1 \mathrm{~b}, 25 \mathrm{c}: 1 \mathrm{~b}, 35 \mathrm{c}$, postpaid. Not prepaid, 5 1bs, $\$ 1.30$; 25 Ibs, $\$ 4.50 ; 100$ lbs, $\$ 16.00$.

597 Iaxton's Progress. (70 days). The earliest and heaviest yielder of the new large-podded types of dwarf Peas. An improved Laxtonian, being earlier and averaging one more pea to the pod. Pods like the Telephone varieties, 4 inches long, broad and pointed, deep green in color. Pods contain 8 large, dark green peas of high quality. Height 18 inches. Pkt, 10c; $1 / 21 \mathrm{~b}, 25 \mathrm{c}$; 1b, 40c; postpaid. Not prepaid, $5 \mathrm{lbs}, \$ 1.50 ; 25 \mathrm{lbs}, \$ 5.25$; 100 los, $\$ 17.50$.

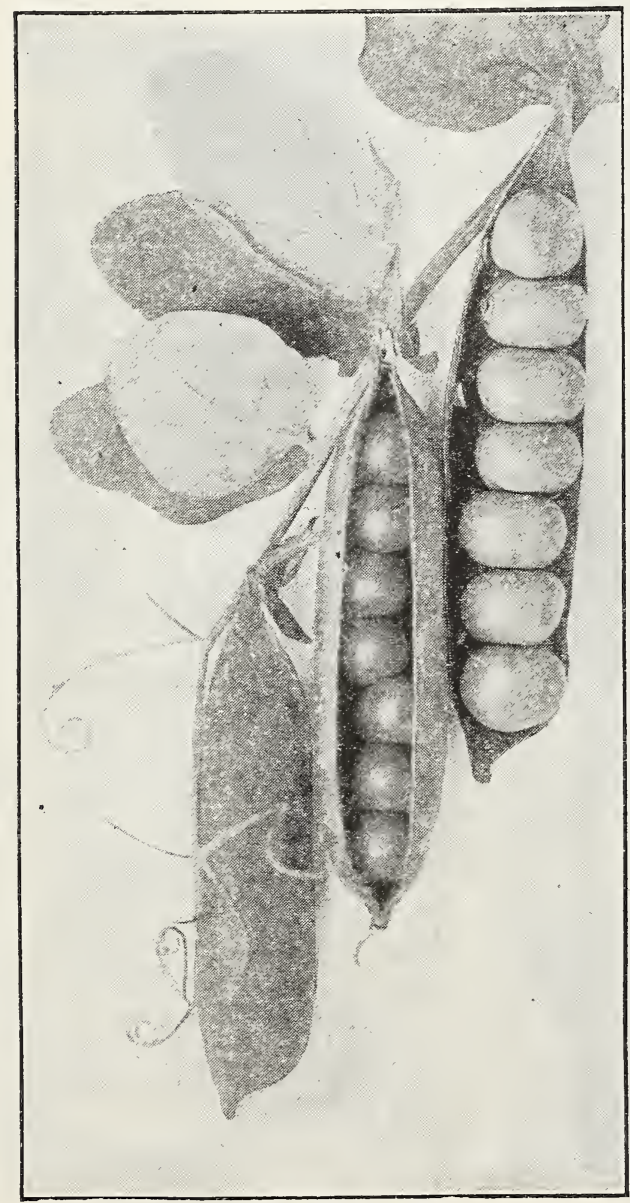

Little Marvel Peas.

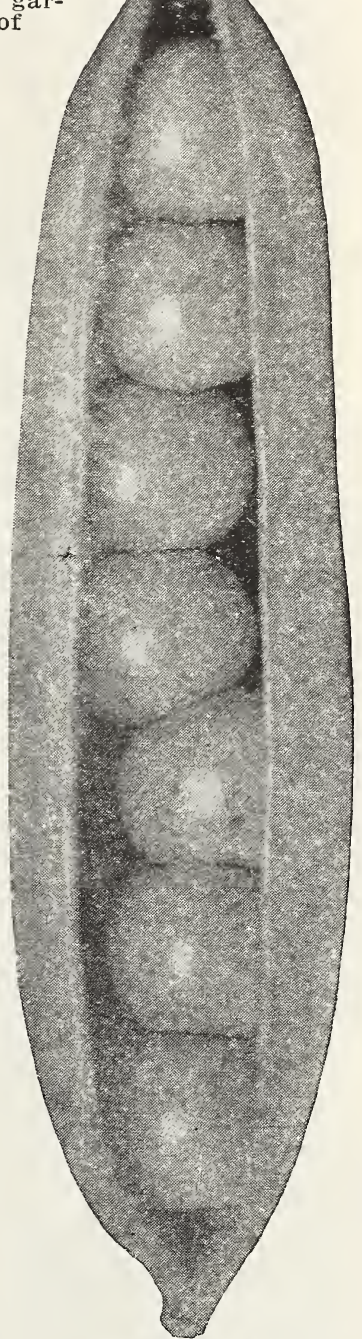

Laxtonian Peas.

592 Iaxtonian or Blue Bantam. (75 days). The original variety of this productive new class. Some what similar to Gradus, but more dwarf, earlier and large pods like the Telephone. Deep green pods 33 inches long. straight and pointed. Pods contain 6 to 8 large, dark green peas. Deep green, feet high Pkt, 5c: $1 / 2$ 1b, $25 \mathrm{c}$; 1b, 35c, postpaid. Not prepaid 5 1bs, \$1.40. 25 1bs, $\$ 5.00$; 100 1bs, $\$ 17.25$.

Peas are one important crop that should always be raised from Mountain Grown Seed. 


\section{GARDIN PFAS-Continued.}

593 Thomas Iaxton. ( 78 days). A selection from Gradus, being a more abundant yielder, and possibly better flavor. Pods slightly smaller but round and square-ended, containing 7 medium dark green peas of excellent quality. Medium green pods $31 / 2$ inches long. Vine moderately stout, grows $21 / 2$ feet high. Pkt, 5c:1/2 1b, 25c: 1b, 35c, postpaid Not prepaid, $5 \mathrm{lbs}, \$ 1.40 ; 25 \mathrm{lbs}, \$ 5.00 ; 1001 \mathrm{bs}, \$ 18.00$.

591 Gradus or Prosperity. (78 days). This fine variety combines earliness with large size. The pods are similar to the late 'Telephone types, medium green, $3 \% / 4$ inches long, semi-round, straight, slightly curved at the tip and pointed. The pods contain 6 to 8 large, very sweet, medium green peas. The high quality of the peas has made this one of the most widely cultivated types. Height 3 feet, moderately heavy vines. Plkt, $5 \mathrm{c} ; 1 / 21 \mathrm{~b}, 25 \mathrm{c} ; 1 \mathrm{~b}, 35 \mathrm{c}$, postpaid. Not prepaid, $5 \mathrm{lbs}, \$ 1.40 ; 25 \mathrm{lbs}, \$ 5.00 ; 100 \mathrm{lbs}, \$ 18.00$.

611 Melting Sugar Pod, Dwarf. (80 days). Edible pods are cooked when young and eaten the same as string beans; they are very sweet, brittle and stringless. Light green pods are $21 \%$ inches long, $1 / 2$ inch broad and square-ended. Pods contain 7 light green peas. Vines are medium heavy, grow 3 feet high and have very pretty purple blossoms. $\$ 1.25 ; 25$ 1bs, $\$ 5.00$.

608 Dwarf Telephone. (88 days). A dwarf strain of the popular Telephone, being bred from Carter's Daisy and

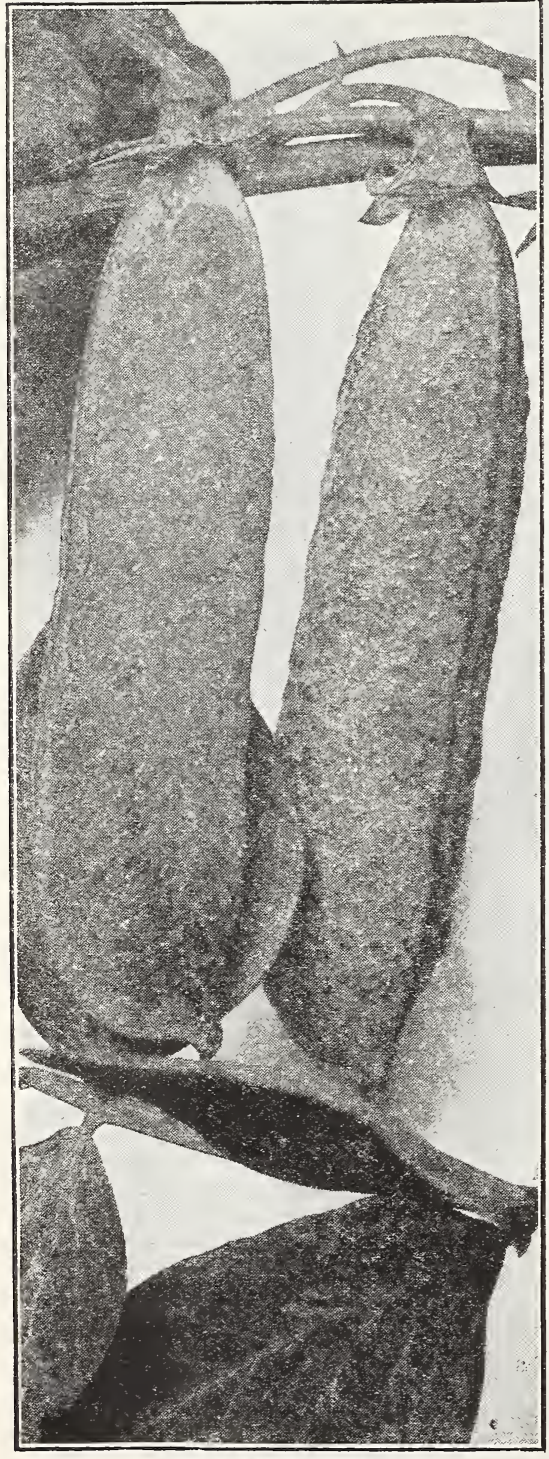

Thomas Laxton Peas. improved over in the larger and darker green pods. phone has long been the favorite with with $\mathrm{h}$ i mountain shipping trade. Our strain of this variety is bred especially for the needs of this trade, making it well suited to all particular planters. Fkt, $5 \mathrm{c} ; 1 / 221 \mathrm{~b}, 25 \mathrm{c} ; 1 \mathrm{~b}, 35 \mathrm{c}$, postpaid. Not prepaid, 5 1bs, $\$ 1.45 ; 25$ Ibs, $\$ 4.40$; 100 Iles, $\$ 16.75$.

607 Improved Stratagem. (85 days). A fine old favorite dwarf main crop Pea. Pods $41 / 2$ inches long, slightly curved, pointed and dark green. Pods contain 8 to 9 medium green peas of fine quality. Height 2 feet, does not require staking. Pkt, $5 \mathrm{a} ; 1 / 21 \mathrm{~b}, 25 \mathrm{c} ; 1 \mathrm{~b}, 35 \mathrm{c}$, rostpaid Not prepaid, 5 lbs, $\$ 1.45 ; 25$ $1 \mathrm{bs}, \$ 4.40 ; 100 \mathrm{lbs}, \$ 16.75$.

609 Tall Telephone. (90 days). For main crop, the heaviest yields and the finest Peas in the largest pods are found in the Telephone types. Pods are $4 \frac{1}{2}$ inches long, straight, broad and pointed, pods contain 8 large, light green peas of fine quality. Strong, heavy vine grows 4 feet high. Pist., $5 \mathrm{c}$; $1 / 21 \mathrm{~b}, 25 \mathrm{c}$; $1 \mathrm{~b}, 35 \mathrm{c}$, postpaid. Not prepaid, $5 \mathrm{lbs}, \$ 1.40 ; 25 \mathrm{lbs}$, $\$ 4.35 ; 100$ 1bs, $\$ 16.00$.

My catalog has been torn and I don't know how much to send for my beans but am going to send just the same. I have so much better beans from you and always have a better garden when I get your seed. Have used your seed for the last eight years.

MRS. L. P. TRUSTY. New Castle, Colo.

Please send me one of your 1929 seed catalogs by return mail. I have used your seeds for three years now and don't think they can be beat.

MRS. JOHN FORAKIS,

Altonah, Utah.
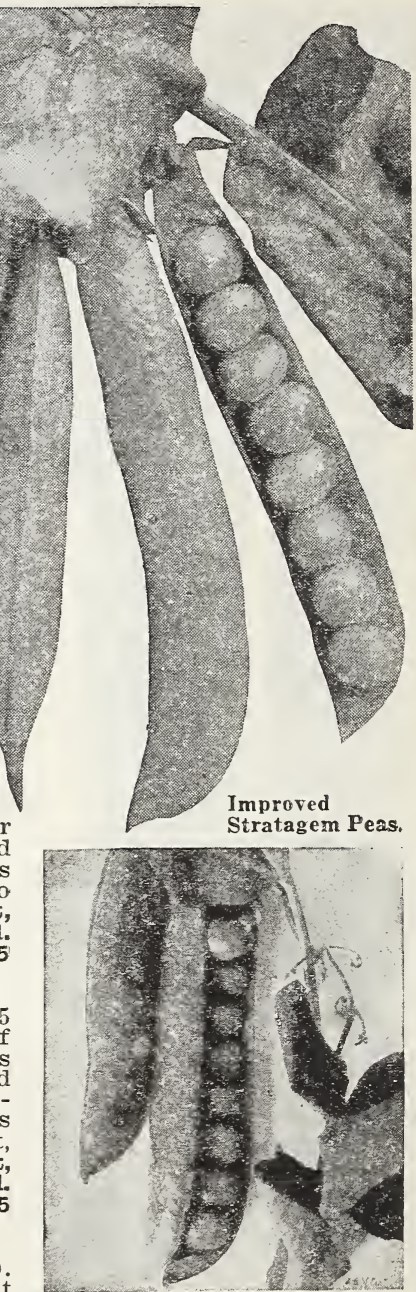

Gradus Peas.

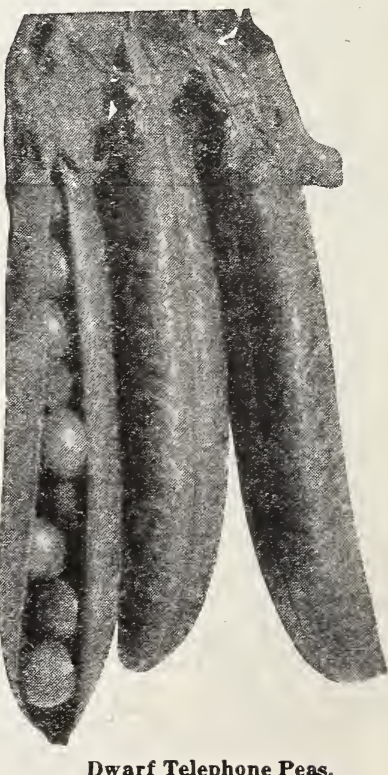




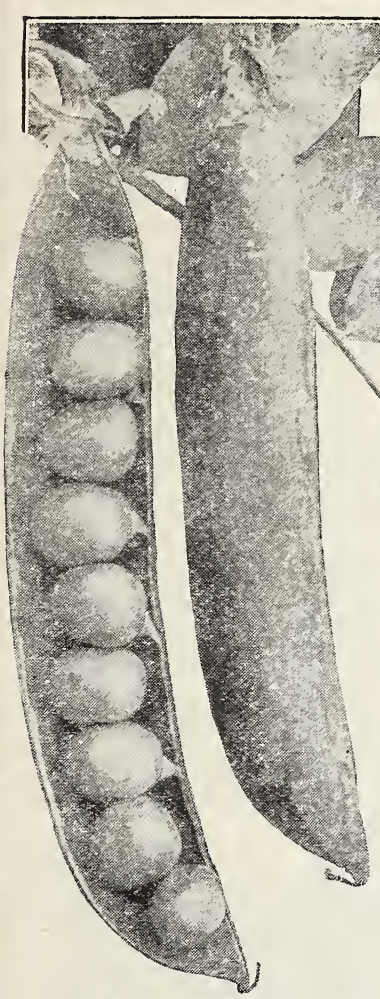

Alderman Peas.

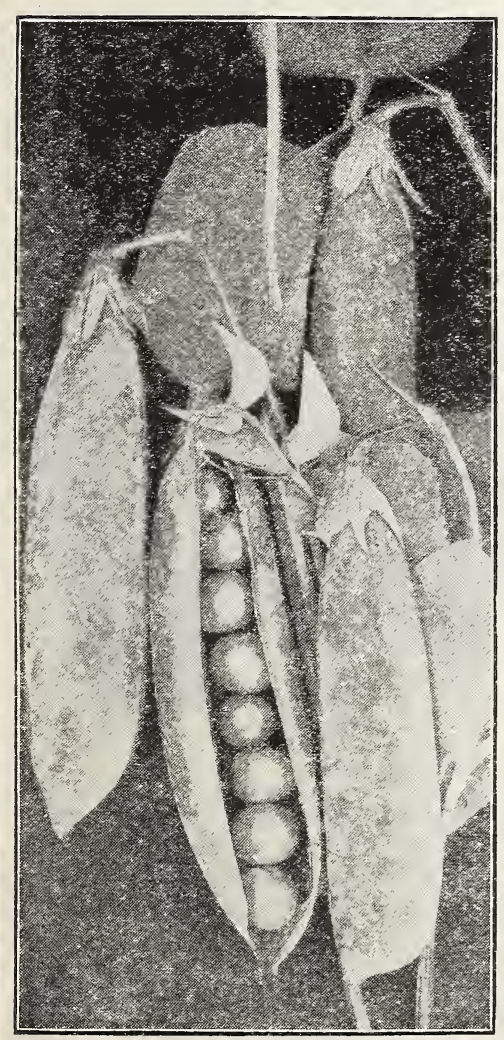

Bliss Everbearing Peas.
GARDERT PFAS-Continued.

600 Dwarf Giant Pod. (82 days).

The best main crop Pea for the

home garden. Not only an

enormous yielder of large pods,

but also peas of the finest fla-

vor. The dark green vines are

exceptionally stout, grow 21/2

feet high and do not require

staking. Pods are a very dark

green, straight, pointed and usually contain 9 very large, dark green peas of tempting appearance and excellent quality. The seed of this variety has been scarce and some customers ordering late have been disappointed. This year we hope to have enough Dwarf Giant Pod seed to take care of all our customers. Pkt, 10c; $1 / 21 \mathrm{~b}, 35 \mathrm{c} ; 1 \mathrm{~b}, 50 \mathrm{c}$, postpaid. Not prepaid, 5 lbs, $\$ 1.75$; 25 1bs, $\$ 6.00 ; 100 \mathrm{lbs}, \$ 22.00$.

601 Alderman. (95 days). Differs from the Tall Telephone in that it has darker pods and peas. Alderman is also more vigorous and immensely prolific. Strong, stout vines grow 4 feet high. Loaded with pods $43 / 4$ inches long, very broad, pointed, straight with a slight curve at the tip. Pods contain 9 extra large medium green peas of finest quality. Pikt, 10c; 1/2 1b, 25c; 1b, 35c, postpaid. Not prepaid, 5 ibs, $\$ 1.50$; 25 1bs, $\$ 5.25$; $100 \mathrm{lbs}, \$ 17.00$.

602 Bliss Everbearing. (90 days). Exceedingly productive and continues to bear for a long season. Vine is closely jointed and the pods are usually in pairs. Plant frequently forms many stalks from a single root. Pod 3 inches long, straight, pointed and contains 4 to 5 light green peas of good quality. Sturdy vines, $20 \mathrm{c} ; 1 \mathrm{~b}, 35 \mathrm{c}$, postpaid. Not prepaid, 5 lbs, $\$ 1.40 ; 251 \mathrm{bs}$, $\$ 4.75$; 100 1bs, $\$ 16.00$.

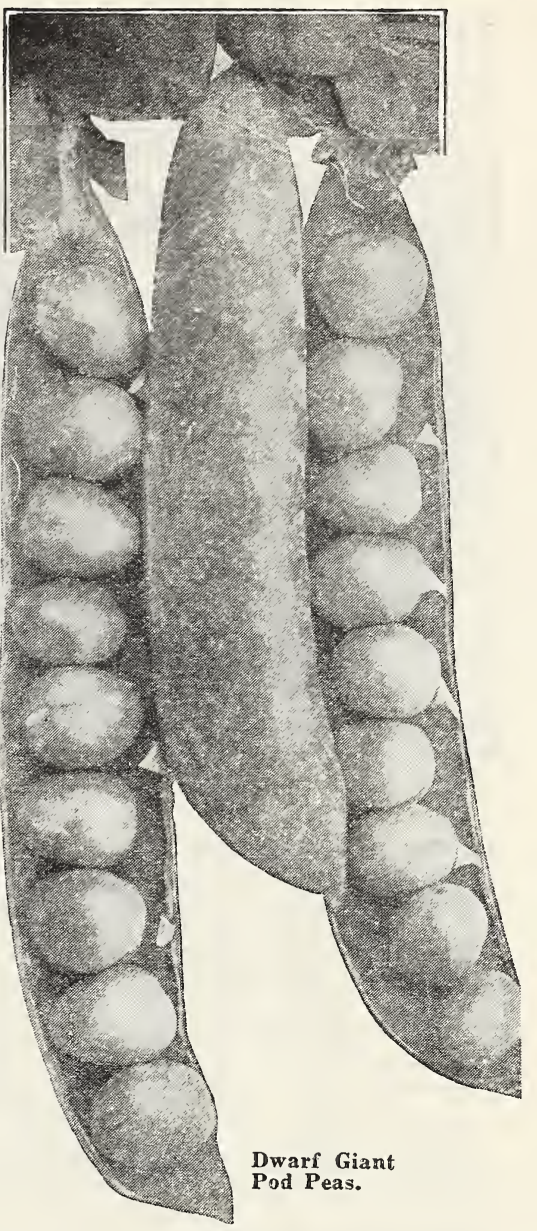

\section{Pea Collections}

Containing early, midseason and main crop Peas. Plant a collection at one time for a long season of fine green Peas.

\section{Please Order Collections by Number}

\section{No. 1 Pea Collection}

\section{5c, postpaid}

1 pkt. Alaska Peas.

1 pkt. Ward's Bestever Peas.

$1 / 2$ 1b. Dwarf Telephone Peas.

\section{No. 2 Pea Collection}

\section{$55 \mathrm{c}$, postpaid}

$1 / 2$ 1b. Alaska Peas.

$1 / 2$ lb. Ward's Bestever Peas.

$1 / 2$ lb. Bliss Everbearing Peas.
No. 3 Pea Collection 70c, postpaid

$1 / 2$ 1b. Alaska Peas.

1/2 1b. Laxton's Progress Peas. 1 lb. Dwarf Giant Pod Peas.

\section{No. 4 Pea Collection}

\section{$\$ 1.20$, postpaid}

1 lb. Alaska Peas.

1 lb. American Wonder Peas.

1 lb. Dwarf Giant Pod Peas.

1 lb. Bliss Everbearing Peas. 


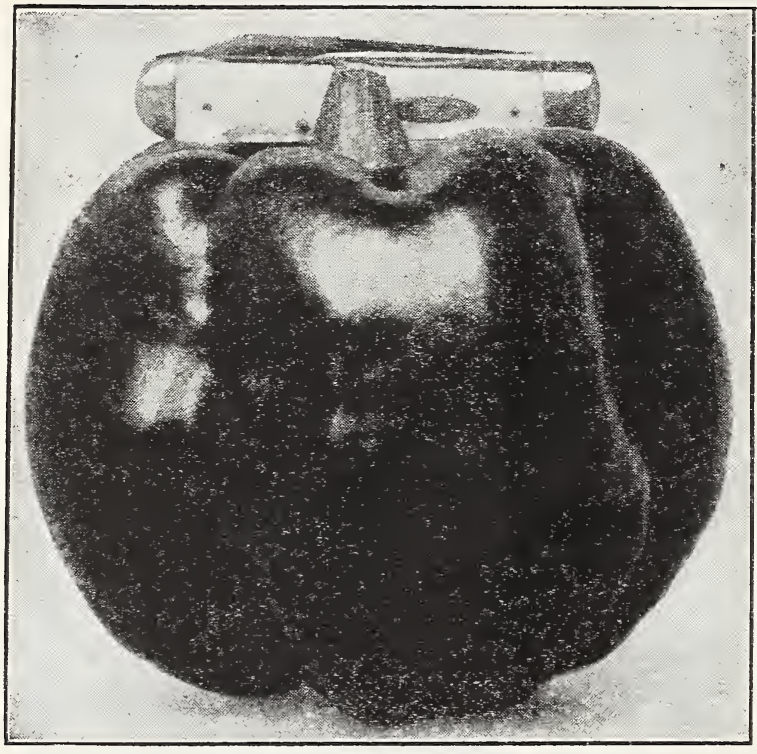

Clinese Giant Pepper.

618 Irarge Bell or Bull Nose. (100 days). Extremely early and popular for pickling. The pendent scarlet fruits are two inches in diameter, three inches long and blunt ended. Occasionally a plant will produce hot fruits, but usually they are sweet. Plat, 10c; $1 / 2$ oz, 25c; oz, $40 \mathrm{c} ; 1 / 4$ 1b. $\$ 1.20 ; 1 \mathrm{~b}, \$ 3.55$, postpaid. INot prepaid, 5 los, $\$ 13.50$

619 Early Mountain. (100 days). One of the very earliest Peppers and the fruits are always sweet. Plants about 15 inches high and quite compact in growth. Will yield more early Peppers than any other variety. Tomato-shaped fruits with a true Sweet Pepper flavor. Wonderful for Summer salads. A variety well recommended for the home garden. Pkt, 10c; $1 / 2 \mathrm{cz}, 30 \mathrm{c} ;$ oz, $45 \mathrm{c} ; 1 / 41 \mathrm{~b}, \$ 1.40$ lb, $\$ 4.25$, postpaid. Not prevaid, 516 , $\$ 17.00$.

\section{Peppers}

(See page 48 for Pepper Plants).

Peppers add a zest to even the most common dishes and will put in that flavor to rouse the lagging appetite of a hot Summer day. Peppers can be prepared for the table in so many ways that they are always a novelty. A few plants will furnish a big yield in the home garden.

Peppers are one of the best paying market crops. The large varieties always command an excellent price on the market, although the earlier varietics can often be put on a nearby market at very attractive prices. Most varieties are eaten when green before they ripen and turn red, but the Sunnybrook is equally good red or green.

Culture. One ounce produces 1,500 plants, 4 to 6 ounces are required for an acre. The seed requires plenty of moisture and warmth to germinate. Peppers should be started in a hotbed, cold frame or box and transplanted about the end of May in most localities. A light, rich warm soil is best, although they will do well in a sunny corner of the garden. Plant in rows about 2 feet apart and about 2 feet apart in the rows. Sweet Peppers should not be grown near Hot Peppers or they will take on some of the hot flavor.

624 sunnybrook. (110 days). An improved Pimento. As sweet as an apple, and the flesh is unusually thick. Medium size 3 inches thick by $21 / 4$ inches deep, just right size for stuffing. The very best Pepper for canning. Small, bushy plants are just loaded with deep green fruits which turn a bright glossy scarlet. Fkt, 10c; $\mathrm{I} / 2 \mathrm{cz}, 35 \mathrm{c} ; \mathrm{oz}, 55 \mathrm{c} ; 1 / 41 \mathrm{~b}, \$ \mathrm{i} 0$; 1b, $\$ 4.00$, postpaid. Not prepaid, $5 \mathrm{lbs}, \$ 18.60$.

629 worlabeater. (125 days). A cross between Ruby King and Chinese Giant. Produces uniformly large Peppers almost as large as Chinese Giant but with a slimmer form and with the brilliant appearance of the Ruby King. A vigorous grower, sure cropper and quite prolific. Worldbeater is popular with home gardeners and the shipping trade. Pkt, 10c; $1 / 2$ oz, 25c; oz, 45c; 1/4 1b, $\$ 1.35$; $1 \mathrm{~b}, \$ 4.00$. postpaid. Not prepaid, $5 \mathrm{lbs}, \$ 18.00$.

626 Ruby King. (120 days). The earliest large shipping type of Pepper. Splendid size and handsome anpearance make it a ready seller. Plants are vigorous, very bushy, growing about 2 feet in height and thickly set with fruits. Ruby King fruits are 5 to 6 inches long by 3 inches thick and a bright ruby-red color. Flesh is thick, sweet and mild. Pkt, $10 \mathrm{c} ; 1 / 2$ oz. 25c; oz, $40 \mathrm{c} ; 1 / 41 \mathrm{~b}, \$ 1.20$ Ib, $\$ 3.40$, postpaid. Mot prepaid, 5 1bs, $\$ 14.75$.

617 California Wonder. (130 days). Similar to the Chinese Giant in large size and blocky form, but has an extremely thick flesh. A new variety of real merit. Crimson fruits $41 / 2$ inches long and 4 inches ill diameter. Flesh mild and sweet. Pkt, 20c; 1/2 oz, 65c: oz, $95 \mathrm{c} ; 1 / 4 \mathrm{~kb}, \$ 2.75 ; 1 \mathrm{~b}, \$ 7.85$, postpaiä.

627 Ruby Giant. (130 days). Similar to Ruby King but the fruits are larger and a little broader at the blossom end. Fruits 4-lobed, 5 inches long by $31 / 2$ inches in diameter. per. Firt, 10c; $1 / 2$ oz, 25c: oz, $45 \mathrm{c} ; 1 / 410, \$ 1.35 ; 10, \$ 4.00$, postpaid. Not per. Firt, 10c; $1 / 20 z$,

622 Chinese Criant. ( 135 days). The very largest of all the sweet, mild Peppers. Fruits 4 to 5 inches broad and of equal height, turn a beau-

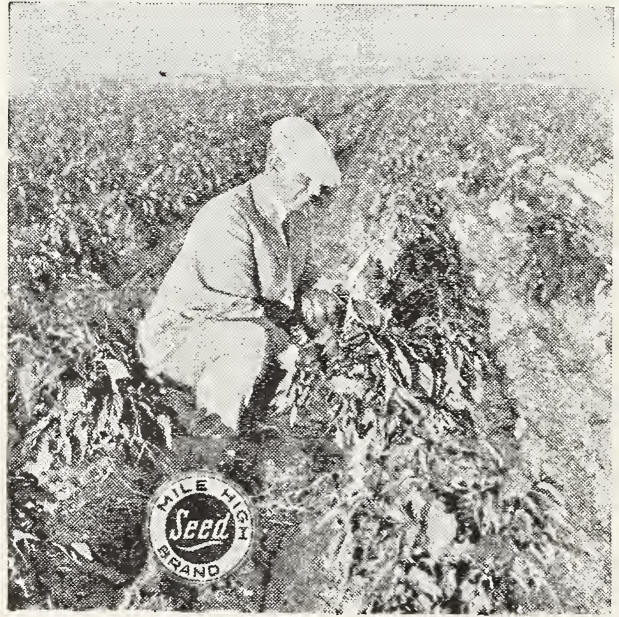
riful, rich gloss Plants $r$ ed stocky in growth. Plkt, 10c; $1 / 2$ oz, $16, \$ 1.75$ $\$ 5.25,21.25$, Not prepaid, 5 Ibs, $\$ 21.00$.

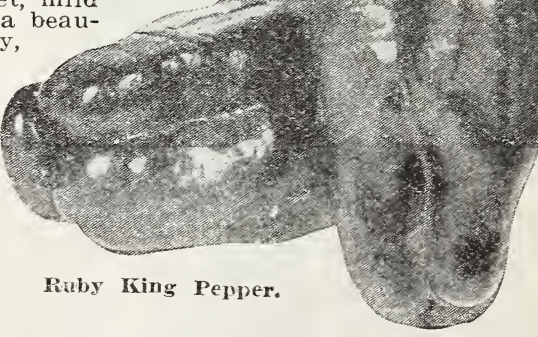

\section{Hot Peppers}

mall-fruited varieties used for spicing and pickling.

621 I.ong Red Cayenne. (120 days). Fruits 4 inches long often curved and twisted, are borne in profusion. Bright red, hot and pungent. Pirt, 10c: $1 / 2$ oz, 25c; oz, 40c; $1 / 41 \mathrm{~b}$, $\$ 1.15 ; 1 \mathrm{~b}, \$ 3.50$, postpaid.

623 Iarge IMexican Chili. (125 days). The large dark red pods are dried and used in making chili and in flavoring other dishes. Pkt, 10c; $1 / 2$ oz, 35c; oz, 55c; 1/4 1b, $\$ 1.65 ; 1 \mathrm{lb}$, $\$ 5.00$, postpaid.

650 Red Chili. (125 days). Yields an enormous crop of fruits 2 to 3 inches long and narrow. The fruits are fiery hot and are much used in pepper sauce, and in pickling. $1 / 2$ oz, 25c; oz, 45c; $1 / 41 \mathrm{~b}, \$ 1.35 ; 1 \mathrm{~b}, \$ 450$, postpaid 


\section{Pumpkins}

Easily grown and excellent for pies. Also one of the cheapest and best feeds for dairy cows, sheep and other stock.

Our Mountain Grown Pumpkin seed is all saved here in the mountain valleys from Pumpkins selected for quality of the flesh, color and size.

Culture. Three pounds per acre alone, or one pound sown with corn. Plant in good soil when the ground has become warm in hills 6 to 8 feet apart each way. Plant 3 inches deep. Thin to two plants to a hill. Cultivate thoroughly until the vines cover the ground. To get largest for exhibition Pumpkins allow only one or two to set on a vine. For Winter storage gather, with the stems on, before frost and store in a warm, dry place.

633 New Yellow Sweet Potato Pie. (80 days). A great producer of small, oval pie Pumpkins and one which will store well for Winter use. Medium size, with deep golden color. Flesh is sweet in taste and cooks quickly. Plkt, 10c; oz, 15c; 1/4 1b, 40c; 1b, \$1.20, postpaid. Not prepaid, 5 lbs, \$5.25.

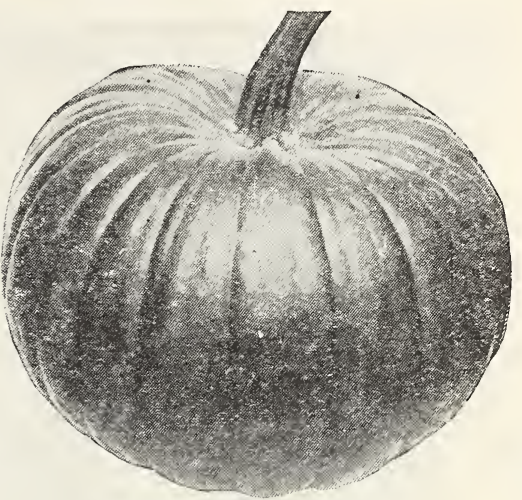

Small Sugar Pumpkin.

636 Green Striped Cushaw. (80|634 Small Sugar or Boston Pie. (70 days). One of the best Pumpkins days). Excellent flavor; flesh for home use, and an excellent quality to can. Ripens quite early and very thick, solid and fine grained. A large Pumpkin that makes excellent pies. Fruits will weigh from 10 to 15 pounds. Mottled green and white striped Pumpkins with a long, crooked neck, large at the blossom end. Flesh yellow. Pkt, 5c; oz, 15c; $1 / 41 \mathrm{~b}$, $40 c ; 1 b, \$ 1.1 .0$, pos
prepaid, 5 1bs., $\$ \frac{4.75}{2.75}$

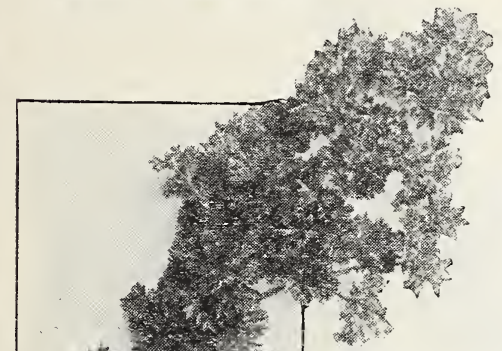
for home use, and an excellent quality to can. Ripens quite early and
is very prolific. Cooks very quickly and is of excellent quality. Fin 8 grained flesh of sweet, delicious flavor. Round Pumpkins average 10 inches in diameter, slightly ribbed, color of skin and flesh a deep orange-yellow. Pkt, 5c; oz, 10c; 1/4 1b, 25c; 1b, 70c, postpaid. Not prepaid, $5 \mathrm{lbs}, \$ 3.10$.

640 Connecticut Field or Big Tom. ( 85 days). The common variety raised for stock feed. Also used for canning. Very prolific and fruits average 15 inches in diameter. Has more distinct ribs but otherwise similar in shape and color to Small Sugar but not as sweet. Fkt, 5c; $\mathrm{cz}, 10 \mathrm{c} ; 1 / 4 \mathrm{~b}, 20 \mathrm{c} ; 1 \mathrm{~b}, 55 \mathrm{c}$, postpaid. Not prepaid, $51 \mathrm{bs}, \$ 2.25 ; 25$ Ibs, $\$ 8.75$.

637 Iring of the Mammoths. (100 days). Of immense size, often 2 feet in diameter, and sometimes weighs 150 lbs. A variety that wins prizes at the fairs. A heavy yielding variety for stock feed. Pumpkins round and flattened, slightly ribbed. Skin salmon-orange; flesh bright yellow and very thick. Pkt, 5c; oz, 15c; 1/4 1b, 40c; 1b, \$1.25, postpaid. irot prepaid, 5 lbs, $\$ 5.25$.

641 Mixed Pumpkins. Some for pies, some for stock feed and a real variety of big ones to show at the fair. Pkt, 5c; oz, 10c; 1/4 1b, 25c; $1 \mathrm{~b}, 70 \mathrm{c}$, postpaid. Not prepaid, $5 \mathrm{lbs}, \$ 2.80 ; 25 \mathrm{lbs}, \$ 11.25$.

\section{Parsley}

Always required for garnishing, also used for flavoring soups and stews and in salads.

Culture. One ounce sows 150 feet of row. Sow early, seed is slow to germinate early radishes can be sown in same row and will be used before Parsley is up. A rich soil is best, but Parsley will thrive in any soil.

579 Champion Moss Curled. (65 days). Best for garnishing, also good for flavoring Very finely cut and closely curled. Compact growing. Dark green color. It leaves are cut off when about 3 inches high, new growth will be brighter and better curled. Fkt, 5c; 0z, 10c; 1/4 1b, 25c; 1b, 80c, postpaid. INot prepaid, $5 \mathrm{lbs}, \$ 3.40$.

582 Plain or Italian. (70 days). Best for flavoring, leaves are not curled. Pkt, 5c; oz, 10c; $1 / 41 \mathrm{lb}, 35 \mathrm{c} ; 1 \mathrm{~b}, 75 \mathrm{c}$, postpaid. Not prepaid, $5 \mathrm{lbs}, \$ 3.25$.

580 Hamburg, Turnip-Rooted. (90 days). The parsnip-shaped root is excellent for flavoring soups, stews, etc. The leaves are like Plain Parsley. Plst, 5c; oz, 10c; $1 / 4 \mathrm{lb}, 30 \mathrm{c} ; 1 \mathrm{~b}, \$ 1.00$, postpaid. Not prepaid, $5 \mathrm{lbs}, \$ 4.25$.

Champion Moss

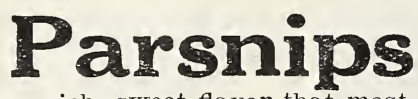

A vegetable for all Winter use, with a rich, sweet flavor that most people like. Easily and cheaply grown. culture. One ounce sows 200 feet of drill; 5 lbs. per acre. Sow early in the Spring, seed is slow to germinate. Sow one-half inch deep in rows 2 feet apart. Thin to 5 inches apart in rows. Frost sweetens the roots. Dig late in the Fall or Parsnips can be left in the ground all Winter.

584 Ward's Marrowfat. (100 days). Rich flavor and fine grained. Uniform good size, fine, long tapering shape, clean, smooth skin. The best variety for table use. Pkt, 10c; $0 z, 20 \mathrm{c} ; 1 / 41 \mathrm{~b}, 60 \mathrm{c} ; 1 \mathrm{~b}, \$ 1.70$, postpaid.

583 Hollow Crown. (110 days). A good cropper, roots 15 inches long, 3 inches in diameter at the top. An old standard varietv Pirt, 5c; oz, 10c; 1/4 1h, 30c;1b, soc, pos'paid. Not prepaid, $5 \mathrm{ibs}, \$ 3.69$.

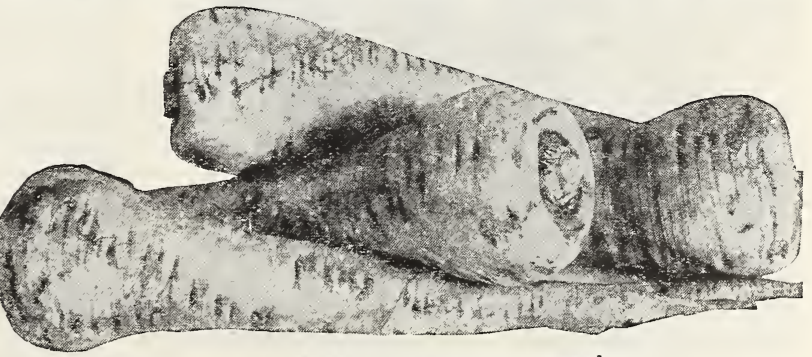

Ward's Marrowfat Parsnips. 


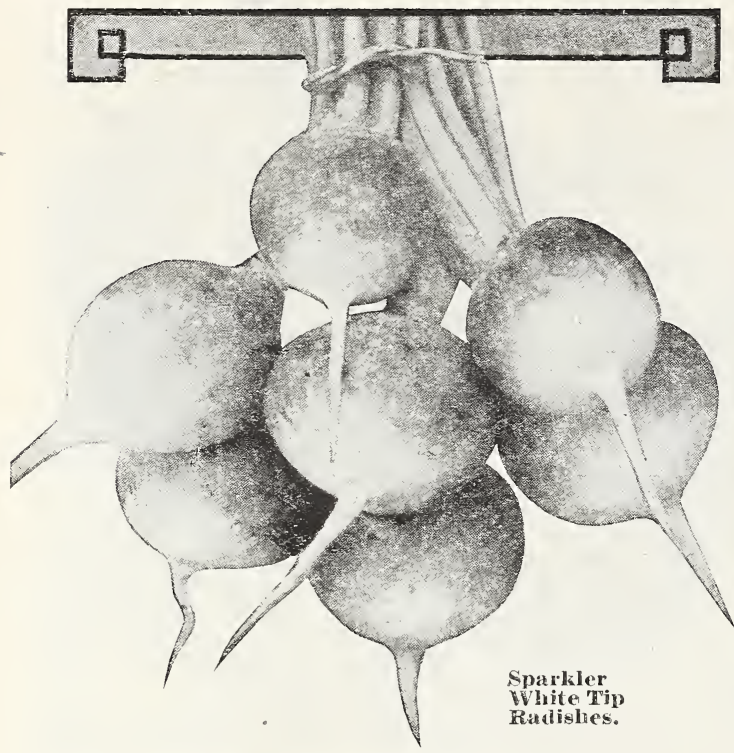

\section{Radishes}

Radishes give interest to the diet and stimulate the dullest appetites. Radishes are healthy, they contain some vitamin $\mathrm{B}$, mineral salts, calcium, sodium, iron and phosphorus. They can be enjoyed from early Spring until late Fall by sowing succession crops, first the Spring varieties, then the Summer and Winter sorts.

Our Radish seed is first selected for true, even types, then we have selected strains that do not run to seed cuickly. You want crisp, solid Radishes and can get these from "Mile High Seeds."

Culture. One ounce to 100 feet of drill, $10 \mathrm{lbs}$, per acre. To grow good Radishes they must be grown quickly with no check in any stage of the growth. All varieties thrive best in light, sandy loam. For early use, Radishes can be grown in the hotbed with plenty of ventilation. In the open garden choose a light, rich soil and water them frequently. Sow the spring varieties every two weeks until hot weather.

647 Earliest Scarlet Button. (18 days). The earliest of all Hadishes and the slowest of its class in shooting to seed. As the quickest growing Radishes are always the most tender and brittle you will really enjoy this one. This small, round Radish has a bright scarlet skin which contrasts beautifully with the pure white flesh. Very small top and tap root, an excellent forcing variety. Pkt, 10c; oz, 15c $1 / 4$ 1b, 40c; 1b, $\$ 1.20$, postpaid. INot prepaid,

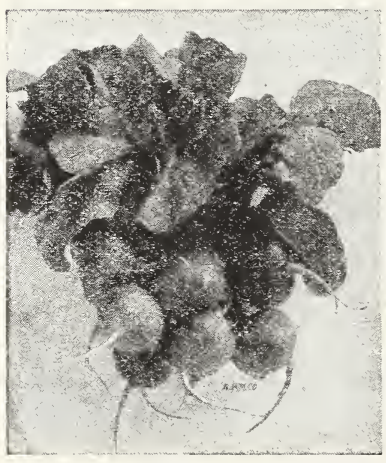

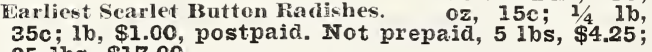
25 ibs, $\$ 17.00$

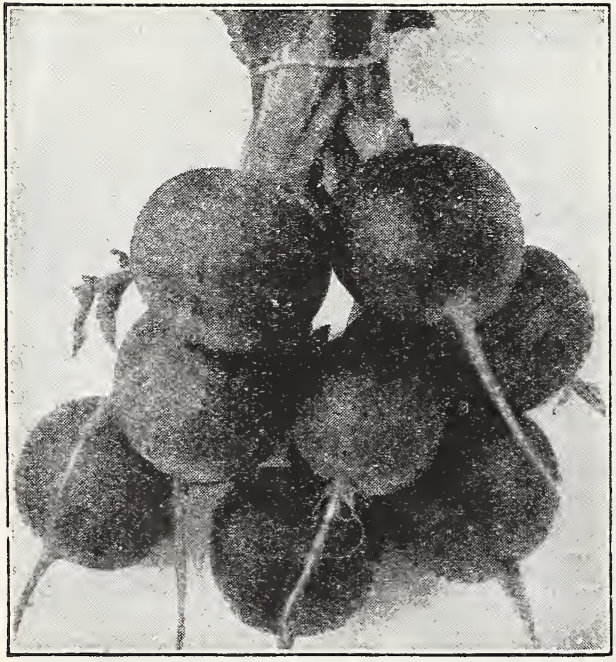

Early Scarlet Turnip Radishes. growing. Very
652 Vick's Scarlet Globe. $(22$ days) An exearly, fair sized, long, globe variety. Color brilliant scarlet. Surform in shape and size, making it excellent for a market variety, for green hou se growing or for the home garden. Small top allows of close early, erisp mild and tender. Plit, 5c; $5 \mathrm{lbs}, \$ 5.25$.

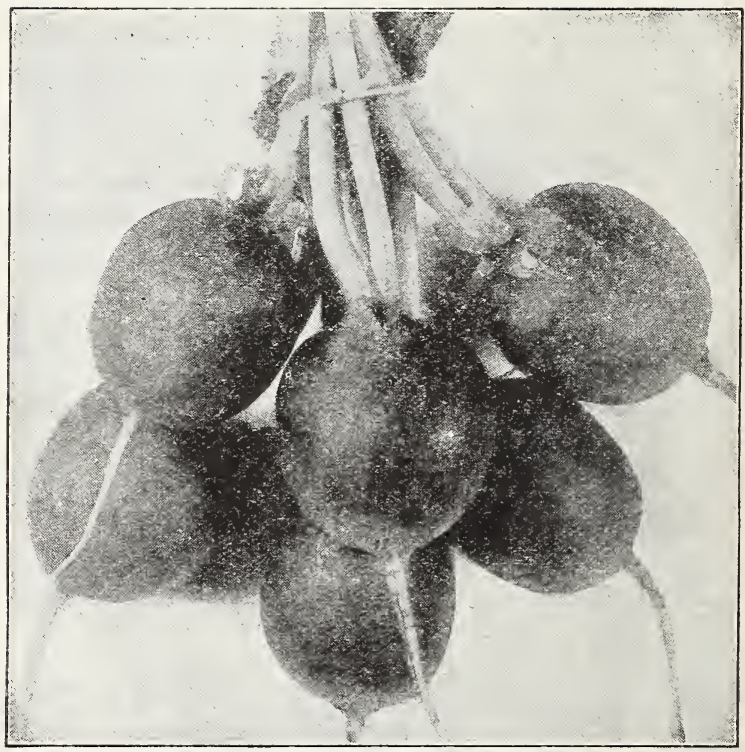

Vick's Scarlet Globe Padishes.

648 Early Scarlet Turnip. (21 days). A good variety for outdoor planting. Small, round variety of a deep, rich scarlet color. Crisp, tender flesh. Pkt, 5c; oz, 15c; $1 / 4 \mathrm{lb}, 35 \mathrm{c} ; 1 \mathrm{~b}, \$ 1.00$, postpaid. INot prepaid, $5 \mathrm{lbs}, \$ 4.25$; $25 \mathrm{lbs}, \$ 17.50$.

650 Eariy Scarlet Turmip white Tip. (21 days). Similar to Early Scarlet Turnip but has an attractive white tip. $1 \mathrm{~b}, 90 \mathrm{c}$, postpaid. Nvot prepaid, $5 \mathrm{lbs}, \$ 3.75 ; 25 \mathrm{lbs}, \$ 16.00$.

649 Sparkler White Tip. (21 days). The most brilliant in appearance of all Radishes. The upper half of the root is a brilliant scarlet, almost the entire lower half a pure white. This strain runs remarkably uniform in color, size and true ball shape. The best selling variety on practically all markets. Pkt, 5c; oz, 15c; 1/4 1b, 35c $1 \mathrm{~b}, \$ 1.00$, postpaid. Not prepaid, 5 los, $\$ 4.25 ; 25 \mathrm{lbs}, \$ 17.00$.

Last Spring I received a price list of Mountain Danvers Onion Seed. It gave us the best results of any seed we have tried and I wish to get some more like it M. CUTLER, Spokane, Wash. 


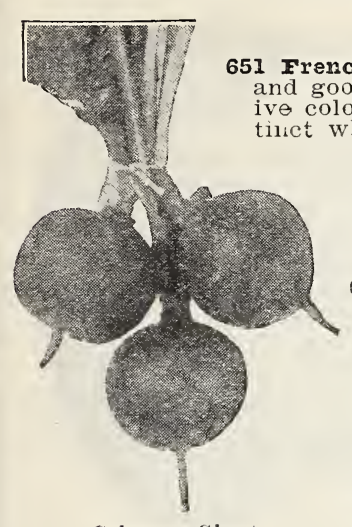

Crimson Giant.

\section{RADISFIS-Continued.}

French Breakfast. (22 days). Quick growth size, combined with a very attractColor a bright scarlet with a dise tip. Oblong in shape. A splenness and attractive color. In best condition for use when small. Pkt, 5c; 0z, 15c; 1/4 1b, 35c; 1b, \$1.00, postpaia. Not prepaia, 5 lbs, $\$ 4.25$; $25 \mathrm{lbs}, \$ 17.00$.

657 Iong Scarlet Short Top. (32 days). The short top of this variety allows of very close planting. A long, straight, smooth, scarlet Radish that is tender, crisp and sweet. Grows 6 inches in length but can be used long before full ¿qc; $1 \mathrm{~b}, 95 \mathrm{c}$, postpaid. Not prepaid, 5 Ibs, \$4.00; 25 1bs, $\$ 16.00$. 359 Cincinnati Market. (32 days). Bred originally for greenhouse trade, now a favorite in many sections. Small tops allow close growing. Slightly larger than Long Scarlet Short 100 p and has a white tip. prepaid, 5 ilvs, $\$ 4.50$.

658 Improved White Icicle. (28 days). An extra early, long, white Radish. Roots grow long and slender and remain mild and crisp until they are quite large. Long after other varieties have become pithy and gone to seed, the Improved White Icicle is still solid and has that agreeable snappy flavor usually only found in young Radishes. Grows 4 to transparent whiteness. Free from any side shoots, when washed and bunched for market they are very attractive. Short leaves. Most excellent flavor. Pkt, 5c; oz, 10c; 1/4 1b, 30c; 1b, 90c, postpaid. Not prepaid, 5 Ibs, $\$ 4.00 ; 251 \mathrm{bs}, \$ 17.00$.

653 Crimson Giant. (32 days). Double the size of any other early variety. Not only quick growing for such a large variety but remains firm and crisp for a long season. Crimson Giant is similar to Scarlet Globe but larger and remains in edible condition for a much longer season. An excellent outdoor garien sort. Plt, 5c; oz, 10c; $1 / 4170,35 \mathrm{c} ; 1 \mathrm{~b}, 90 \mathrm{c}$, postpaid. Not prepaid, $5 \mathrm{lbs}, \$ 4.00$.

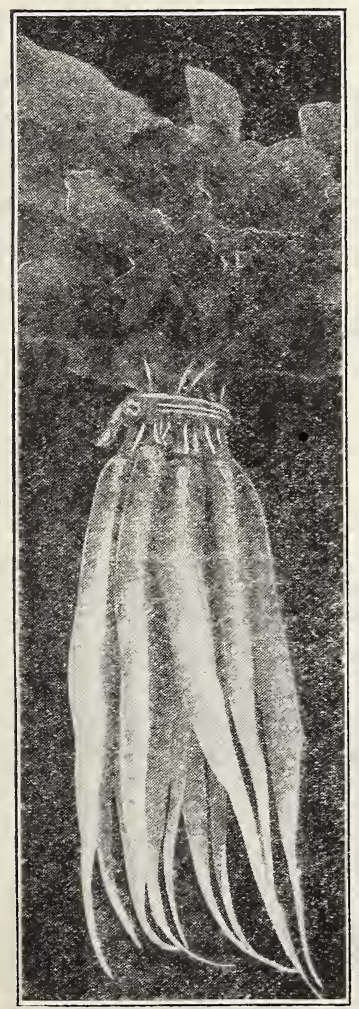

\section{Summer and Winter Radishes}

These can be grown in the warmer weather and will not shoot to seed in hot weather as quickly as the Spring varieties. Summer Radishes should be eaten as soon as large enough. Winter Radishes can be stored for Winte: use ili a frostproof cellar. A delightful was to prepare these varieties is to slice and soak in salt water for 15 minutes before serving.

660 chartier or shepherd. (35 days). The finest appearance of the Summer Radishes. A clear rose colored, long Radish, shading into a pure waxy white at the tips. Grows quickly and atpostpaid. Not prepaid, 5 ibs, $\$ 4.25$.

662 White strassburg. (40 days). Larger and thicker than Icicle. Withstands heat and retains its crispness even when the roots are quite large. An oblong tapering Radish with pure white skin and flesh: firm, brittle and tender. Pkt, 10c; 0z, 15c; 1/4 1b, 35c; 1b, \$1.00, postpaid.

671 Round Black Spanish. (72 days). Keeps best and longest of the Winter Radishes. Round roots 3 to 4 inches in diameter. Skin black; flesh white, crisp and pungent. Plt, 5c; oz, 10c; 1/4 1b, 35c; 1b, \$1.00, postpaid.

668 China Rose. (60 days). Can be used either as a Summer or Winter Radish Not only withstands heat but also keeps splendidly. Cylindrical roots grow 4 to 5 inches long by 2 inches thick. Smooth, bright rose skin. $1 / 2 \mathrm{Ib}, 30 \mathrm{c}$; Ib, $90 \mathrm{c}$, postpaid. IT ot prepaid, 5 ibs, $\$ 3.50$.

669 White Chinese or Celestial. (65 days). May be used in all stages of growth or stored for Winter. Cylindrical roots grow 6 to 8 inches long, smooth. white skin. The mildest of the Winter Radishes. Pkt, 10c; oz, 15c; $1 / 41 \mathrm{~b}, 35 \mathrm{c} ; 1 \mathrm{~b}, \$ 1.10$, postpaid. Not prepaid, $51 \mathrm{bs}, \$ 4.75$.

Send me one pound Valencia Onions as a trial this coming summer. Please quote me on Yellow Bermudas and Mountain Danvers. Your Mountain Danvers were fine last year. So free of diseaso.

LUTHER CARR, Ridgeland,. Miss.

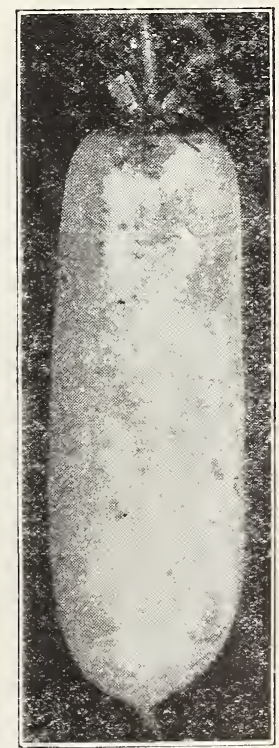

White Chinese. 


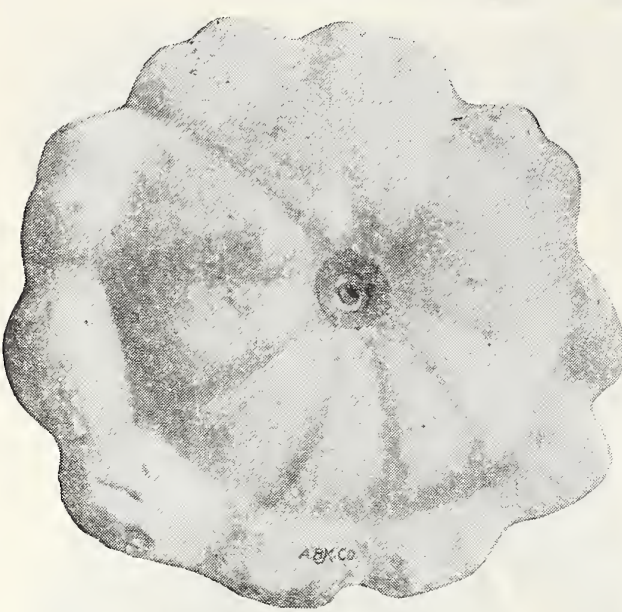

White Bush Scallop Squash.

\section{Squash}

Baked Squash is always a tasty vegetable and Squashes are very easily raised. Also one of the cheapest and best feeds to raise for dairy cows and other stock.

Culture. One ounce to 15 to 40 hills, depending on the size of the seeds; 3 to 4 pounds per acre. Select a well fertilized or rich and well drained soil. Seed should only be planted after all danger of frost is past. Plant in hills 6 to 10 feet apart, planting seeds 3 inches deep. Thin to two plants to a hill.

\section{Summer Squash}

Prized for their distinct flavor and their health giving qualities. Good in vitamin $\mathbf{A}$, contains phosphorus Squash can be fried and is similar young tender fruits and is similar to Eggplant, or the then sliced and seasoned.
686 White Eush Scallop, Patty Pan. (45 days). The tarliest of all Squashes. Fruits, while quite thick, in diameter but should be eaten while quite young. Lquashes comparatively smooth and creamy white color. Plants of bush form and very productive. Fist, $5 \mathrm{c} ; \mathrm{oz}, 15 \mathrm{c} ; 1 / 4 \mathrm{lb}, 40 \mathrm{c}, 1 \mathrm{~b}, \$ 1.20$, postpaid. Not prepaid, 5 lios, $\$ 5.00$.

688 Yellow Surnmer Croolsneck. (50 days). Very early and prolific, small type about 12 inches in length. Fruits moderately warted and a golden yellow color. Should be used while young and before the shell turns hard. Vine is bush type. An

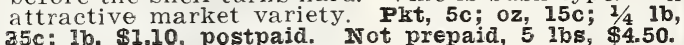

694 Giant Summer Crookneck. (58 days). Larger and more heavily warted than Yellow Summer Crookneck. Also has a superior flavor, being close to the Winter Squashes in flavor Fruits often reach 2 feet in length. Fkt, $5 \mathrm{c} ;$ oz, $15 \mathrm{c} ; 1 / 4 \mathrm{~b}, 40 \mathrm{c}$; $1 \mathrm{~b}, \$ 1.20$, postpaid. Niot prepaid, $5 \mathrm{lbs}, \$ 5.00$.

703 Cocozelle Bush. (60 days). Italian Vegetable Marrow of fine quality. Usually eaten when 6 to 8 inches long. Mature fruits are double that length, and 5 inches in diameter. skin striped alternately green and gold. Plants are bush type and quite productive. Cocozelle Squash makes a tempting dish when sliced and fried in oil. Pkt, 10c; oz, 2Cc; $1 / 41 \mathrm{~b}, 45 \mathrm{c} ; 1 \mathrm{~b}, \$ 1.30$, postpaid. Not prepaid, $5 \mathrm{Ibs}, \$ 5.25$.

\section{Small Table Squash}

Small enough to be baked in the shell and retain their full flavor. Large enough that a half Squash makes a nice serving, avoiding the waste that often occurs when a large Squash is cooked.

698 Ward's Individual Squash. Very finest sweet flavor and for this reason we only offer the one variety of small table Squash. This flavor entitles the Individual Squash to a place among Squashes such as so long held by Golden Bantam among sweet corn. The author of a recent book on Squashes wrote us that he had left Individual out because it appeared to be similar to Delicata, he later discovered his mistake in finding the very superior flavor of the Individual. To prepare for the table, cut in half, place a lump of butter in one half, top with the other half and bake whole. Serve the halves in the shell. The shell is thin and cooks quickly. Individual grows about 7 inches long by 3 inches in diameter. Skin alternately striped green and yellow. Can be used summer and Winter as it ripens early and keeps well. Seed supply is very limited. Fit, 10c; $02,30 c ; 1 / 41 \mathrm{~b}, 90 \mathrm{c} ; 1 \mathrm{~b}, \$ 2.75$, postpaid. Not prepaid, $51 \mathrm{bs}, \$ 12.00$.

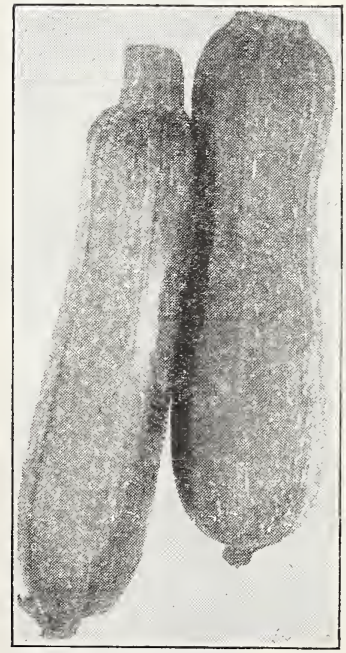

Cocozelie Push Squash.

\section{Winter Squash}

The Hubbards and similar varieties that keep all Winter. Excellent for baking and for Squash pies. A cheaply raised and excellent feed for dairy cows and other stock, many farmers raise 10 acres or more for stock feed. For Winter storage gather Squashes, with the stems on, before frose and store in a warm, dry place.

To Bake Winter Squash. Cut into pieces about 2 inches square, season with salt, peprer and butter. Bake in a moderate oven about 50 minutes. Serve in the shell with butter, or scooped from the shell and mashed.

696 Sibley or Pike's Peak. (85 days). Extra thick meated, fine grained, dry and of excellent flavor. An early desirable variety and very prolific. Size and shape like the Improved Hubbard. Slate gray color makes appearance similar to the Blue Hubbard but the Sibley is more prolific, thicker meat and finer quality. A good keeper. Ekt, 5c; oz, $15 \mathrm{c} ; 1 / 41 \mathrm{~b}, 35 \mathrm{c} ; 1 \mathrm{~b}, \$ 1.10$ postpaid. Not prepaid, $5 \mathrm{lbs}, \$ 4.50$.

692 Golden Hubbard. (80 days). The earliest Hubbard and quite prolific. Slightly smaller than Improved Hubbard. Rich golden color and somewhat warted. An excellent keeper. Very good quality and a favorite canning variety. Pkt, $5 \mathrm{c} ;$ oz, $15 \mathrm{c} ; 1 / 41 \mathrm{~b}, 40 \mathrm{c}$; lb, \$1.20, postpaid. Not prepaid,

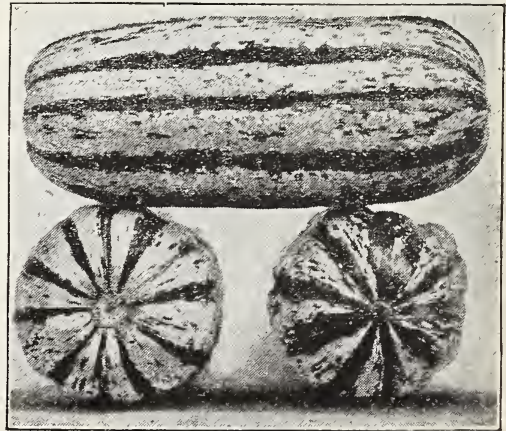

Ward's Individual squash. 


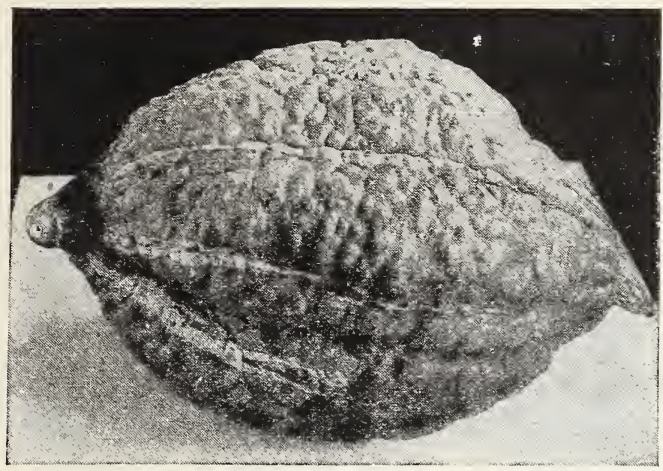

\title{
SQUASE-Continued.
}

690 Delicious. (85 days). Exceptionally fine table quality and an excellent keeper. Somewhat smaller than the Hubbard types, large at stem end, color of skin dark green. Fkt, 10c; 0z, 15c; 1/4 1b, 40c; 1b, \$1.25, postpaid. Not prepaid, $5 \mathrm{lbs}, \$ 5.50$.

69I Improved Hubbard. (90 days). Popular general purpose Winter Squash. Excellent quality and fine grained thick flesh. Fruits pointed at both ends and moderately warted. Color very deep green. Pkt, 5c; $c z, 15 c ; 1 / 41 b, 35 c ; 1 b, \$ 1.10$, postpaid. Not prepaid, 5 ibs, \$4.75.

693 Chicago warted Fubbard. (90 days). The best keeper of all Winter Squashes, being quite heavily warted. Larger than Improved Hubbard, averaging two pounds heavier, and equal quality. Hard shell; color dark bronze-green. Plkt, 5c; oz, 15c; $1 / 41 \mathrm{~b}, 40 \mathrm{c}$; Ib, $\$ 1.15$, postpaid. Not prepaid, $5 \mathrm{lbs}, \$ 5.00$.

\section{Delicious Squash.}

687 Banana. (90 days). Large, long table Squash. Thick, rich flavored meat is excellent for baking. A heavy yielder and excellent keeper. Size 2 feet long by 6 inches in diameter. Color greenish gray. Pkt., 5c; oz., $20 \mathrm{c}$; $1 / 4$ Ib., 50c; 1b., $\$ 1.50$, postpaicl. INot prepaid, 5 Ibs., $\$ 5.75$.

695 Sweet Potato or Green River. Length up to four feet. Good table quality. Color gray. Pkt., 10c; oz., 25c; 1/4 1b., 65c; 1b., \$2.00, postpaid. irot prepaid, 5 lbs., $\$ 7.75$.

689 Mammoth Chili. (90 days). The largest of all Squashes. Size 20 by 16 inches and up, often weighing over 150 pounds. Excellent for stock feed or exhibitions. Skin bright orange and yeilow. Pkt, 5c; oz, 15c; $1 / 4$ Ib., 50c; Ib., \$1.45, postpaid. INot prepaid, 5 lbs., $\$ 6.00$.

700 Mixed Squash Seed. A mixture of all the above types and not a poor Squash in the bunch. Pkt, 5c; oz, 10c; 1/4 1b, 20c; 1b, 60c postpaid. Not prepaid, $5 \mathrm{lbs}, \$ 2.50 ; 25 \mathrm{lbs}, \$ 11.00$.

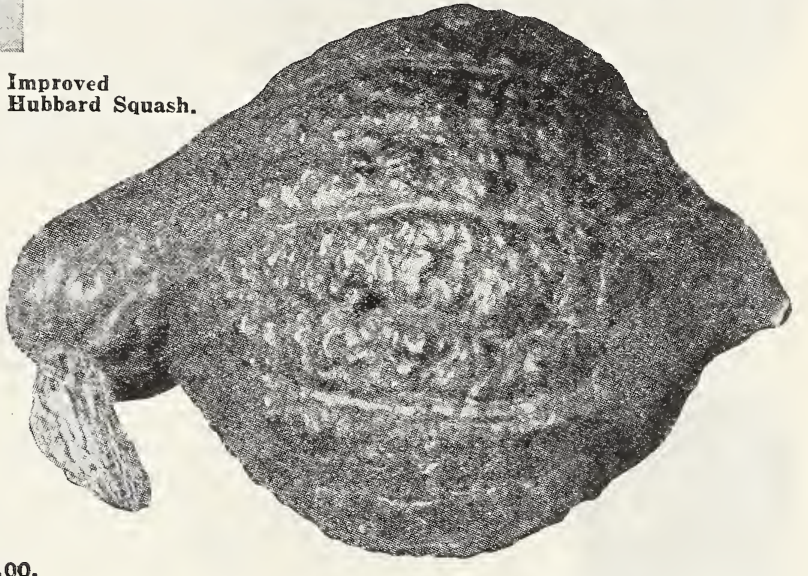
Q M.G.K.

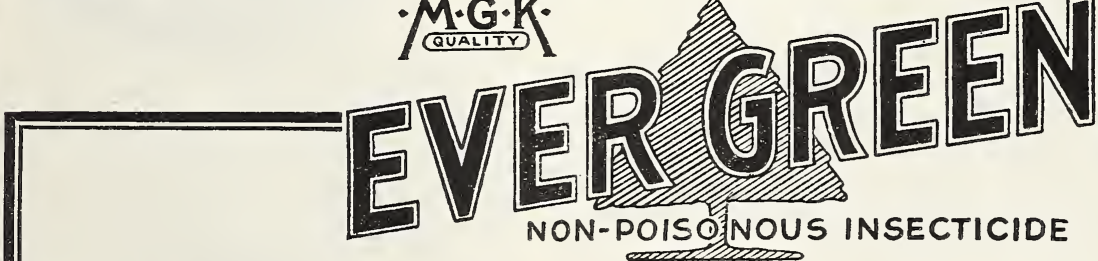

\section{Protects Your Profits by Killing Insects that attack Vegetable Garden and Fruit Crops}

Irills both chewing and sucking types of insects-Mexican Bean Beetles, Squash Bugs, Cabbage Worms and other destructive pests. Ever Green is easy to get, easy to use and absolutely non-poisonous to plants and people. Leaves no poisonous residue on vegetables or fruits. Used by leading commerciai growers everywhere.

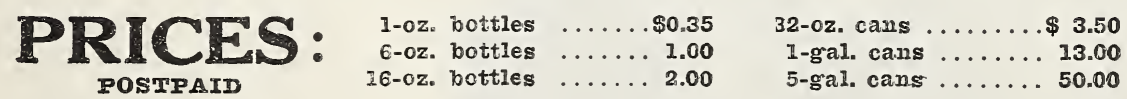

\author{
GRAND JUNCTION SEED CO. \\ GRAND JUNCTION, COLO., Distributors
}




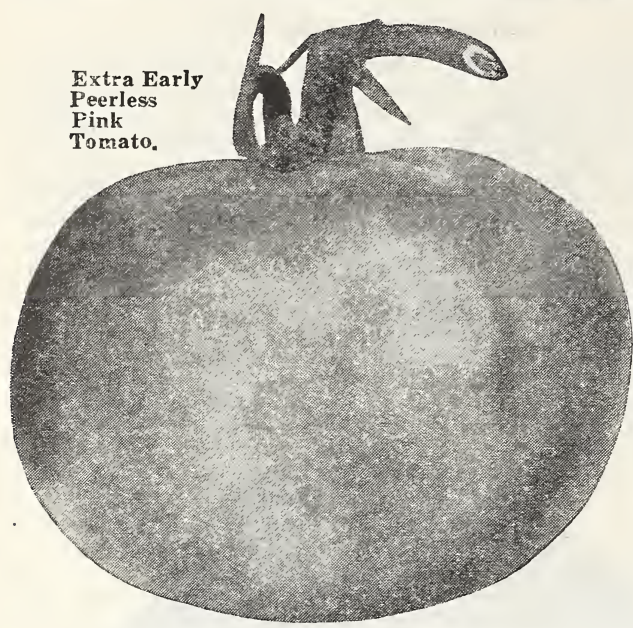

\section{Tomatoes}

Tomatoes make an excellent home garden crop. They thrive in any kind of soil. They take up very little room especially if the plants are staked or grown near a sunny wall. Tomatoes give a very abundant harvest for a considerable season, for the space needed to grow them.

Tomatoes are exceedingly wholesome, rich in vitamins $\mathrm{A}, \mathrm{B}$ and $\mathrm{C}$, mineral salts, calcium and chlorine It is a rea asset to have them continually at hand in the garden, fresh for salads, slicing or preparing in numerous ways. And when they are yielding heaviest a few bushels should be canned for Winter use.

Tomatoes are a valuable crop for the commercial gardeners and shippers. A nice even pack of Tomatoes often brings a fancy price on the market. Our Mountain Grown Tomato seed is selected for the shipping trade, our work in growing Tomatoes is practically entirely devoted to the important shipping varieties. Continual plant selection on these rarieties keeps them in very true form and even type. We will quote special prices for large quantities on request We can usually supply quantities of several sacks of all the leading shipping varieties, but we would urge large shippers to let us know their requirements well in advance so that we can reserve or even grow the seed specially for them.

Mountain Grown Tomato Seed has always been entirely free from disease and blights. The seed from these Tomatoes is naturally disease free and you can plant it with confidence.

For Tomato Plants see page 48.

Culture. One ounce of seed for 2000 plants; 3000 to 4000 plants to set an acre. If seed is planted direct in the field allow 8 ounces of seed per acre Under ordinary conditions it is far better to set plants than to sow the seed directly in the field. Sow the seed in hotbeds or shallow window boxes, cover-

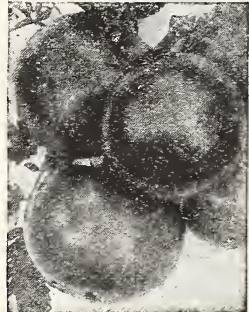

Earliana Tomatoes. ing the seed one-half inch. In northern localities plant the seed in March and April. When the plants are 3 to 4 inches high transplant in hotbeds, cold frames or individual pots, allowing more space and air to harden the plants. After the weather has moderated, set the plants in the open ground. Water freely when transplanted and shelter from the sun for a few days. Cultivate thoroughly as long as the vine growth will allow. The last cultivations should be very shallow. Training the plants on stakes allows of closer planting, improves the quality and is an advantage in many ways.

723 Ward's MLoneymaker. (80 days). An extra early red Tomato of fine quality. Produces fine, smooth Tomatoes earlier than any other red variety and a early as the earliest pinks. A wonderful sort for inarket gardeners who can reach the market at "a
time when Tomato prices are still quite high. An excellent variety for the home garden, not only giving early fruits when they are really appreciated, but the Moneymaker continues to bear for a long season, in many localities until the vines are killed by frost. Moneya little inclined to angularity. Fruits set in heavy clusters on a small, open or flat vine. Cell strncture is irregular. Plst, 10c; 1/2 oz, 65c; oz, $\$ 1.00$; $1 / 4 \mathrm{lb}, \$ 2.75 ; 1 \mathrm{~b}, \$ 8.00$, postpaid. Not prepaid, $5 \mathrm{lbs}, \$ 31.50$.

716 Extra Early Peerless Pink. ( 80 days). The earliest pink Tomato in cultivation. In addition to its extreme earliness, it is much superior to Earliana in table quality, in handsome shape and attractive appearance. liipens more real early fruit than Moneymaker, but may sun-scald when the real hot weather comes. An excellent first early shipping variety and a great seller on any market wanting an early pink Tomato. Pkt, 10c; $1 / 2$ oz, 40c; oz, 65c;1/4 1b, $\$ 1.95 ; 1 b, \$ 6.00$, postpaid.

713 Earliana. (90 days). A very popular, early, smooth, bright red Tomato of good size. Fruits are fleshy, solid and excellent for early markets. Fruits set in large clusters, are medium sized and our "Mile High" strain is re$1 / 20 z, 20 \mathrm{c} ; \mathrm{oz}, 35 \mathrm{c} ; 1 / 41 \mathrm{~b}, \$ 1.00 ; 1 \mathrm{~b}, \$ 3.00$, postpaia. Not preqaia, $51 \mathrm{hs}, \$ 12.50$.

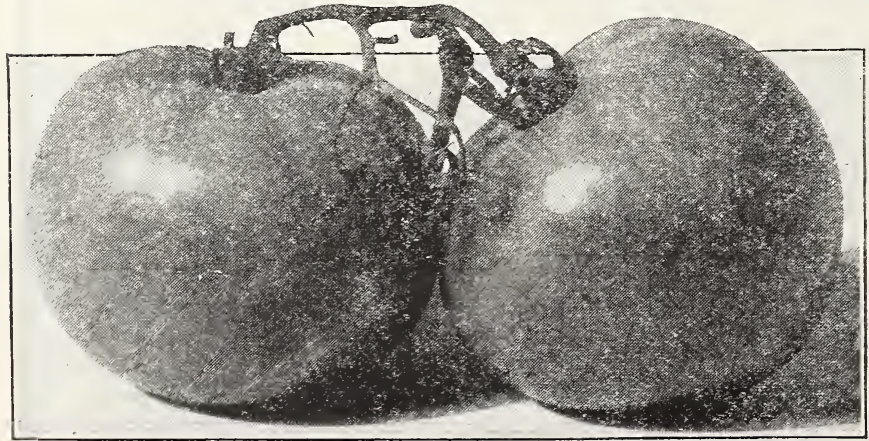

715 June Pink. (90 days). A pink Earliana, being very similar to the Earliana in many ways. A very popular shipper, fruits are of medium size and ship well. Solid fruits set in clusters of five or more. Vine open and not large. Prt, $5 \mathrm{c} ; 1 / 2$ oz, $25 \mathrm{c}$ $0 z, 400 ; 1 / 410, \$ 1.25 ; 1 \mathrm{~h}, \$ 3.75$, postpaid. Rot prepaid, 5 1 bs, $\$ 17.00$.

710 Bonny Best. (95 days). A splendid second early, even, round fruits. Vine vigorous and very productive. An excellent variety for the home garden. Scarlet fruits set in clusters of three to five. Fruits are round, high crowned and of medium size, Pki, 10c; $1 / 2 \mathbf{~ o z}$, $20 \mathrm{c} ;$ oz, 35c; $1 / 4$ 1b, 95c; 10, \$2.90 


\section{TOMATOES-Continued.}

714 John Baer. (100 days). Early solid fruits, an excellent variety for early canning. Deep glossy red, similar to Earliana, but more solid flesh and fewer seeds. Fruits medium size, round and high crowned. Vine makes good growth. Plkt, 5c; $1 / 2$ oz, 20c; oz, 35c; $1 / 4$ 16, $\$ 1.10$; Ib, $\$ 3.40$, postpaid. Not prepaid, 5 Ibs, $\$ 13.75$.

711 Chalk's Early Jewel. (100 days). A good early canner. Ripens up to the stem, a bright scarlet. Heavy cropper. Fruit good, medium size, excellent flavor. Vine open and medium size. Fkt, $10 \mathrm{c} ; 1 / 2$ oz, 20c; oz, 35c; $1 / 41 \mathrm{~b}, \$ 1.10 ; 1 \mathrm{lb}, \$ 3.25$, postpaid. Irot prepaid, $51 \mathrm{bs}, \$ 14.50$.

720 Cooper's Special Globe. (110 days). Known as a self-pruner. Similar to Livingston's Globe, but the vine is shorter. While the vine is still small it sends out side branches. The fruits set in clusters every 5 to 6 inches along the stalk. Fruits similar to Livingston's Globe but slightly smaller. Fkt, $10 \mathrm{c} ; 1 / 2$ oz, 30c; Oz, 50c; $1 / 4110, \$ 1.45 ; 1 \mathrm{~b}, \$ 4.40$, postpaid. "2ot prepaid, 5 ibs, postpaid.

712 Ward's Jumbo. (115 days). Smooth, extra large, solid and meaty. Jumbo is an excellent main crop variety for the home garden. A slice of this enormous Tomato looks like a piece of beetsteak. Solid construction, no trace of core and very few seed cells. Delicious flavor makes the Jumbo extra fine for slicing or canning. The acid content is small so that everyone can enjoy them. The vine is of vigorous growth and the fruits set in many clusters of 3 to 5 . Fruits often weigh over a pound each. Deep pink color and much smoother than Ponderosa. Pkt,

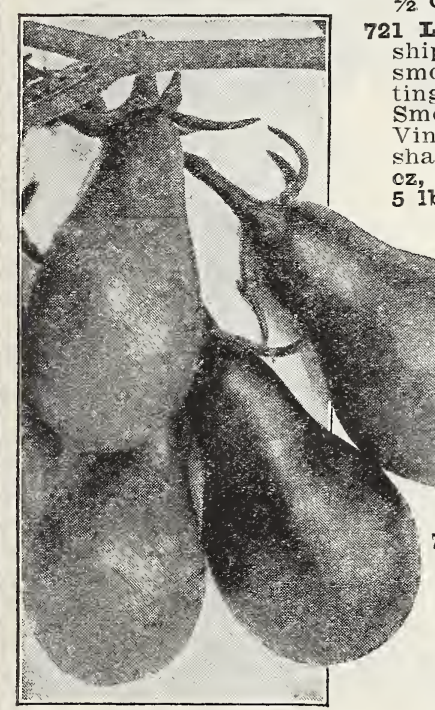

Yellow Pear Tomatces. 1 Livingston's Globe. (110 days). One of the greatest shipping Tomatoes. Attractive fruits are large size, mooth, firm and ripen evenly. Color a glossy rose, inged with purple. Mild, pleasant and delicious flavor Smooth Tomatoes are globe-shaped and high crowned. Vine makes good growth and has heavy cut foliage,

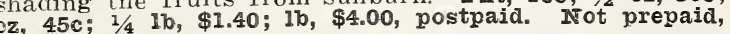
5 Ibs, \$18.00.

726 Marglobe. (110 days). Developed by the United States Department of Agriculture for resistance to rust and wilt. The Marglobe has proven to be the finest all purpose Tomato. A very heavy yielder, bearing many clusters of 5 to 7 fruits. Bright red color and ripens well up to the stem. A vigorous grower and found to be adapted to all sections. An excellent canning type and a very good shipper. A cross between the Marvel and Livingston's Globe it has retained the good features of each. Smooth, solid fruits are quite deep from stem to blossom end and practically round. Our seed is directly descended from Professor Pritchard's original Marglobe. Pkt, 10c; 1/2 oz, 30c; oz, 50c; 1/4 1b, $\$ 1.45 ; 1 \mathrm{~b}, \$ 4.75$, postpaid. Not prepaid, 5 1bs, $\$ 21.50$.

17 Fonderosa. ( 125 days). Extra large purple-pink fruits for main crop. Fruits are solid and meaty with few seed cells. Vine is of open and vigoropen growth, quite ous growth, quite
productive, bears until fros t. Splendid slicer Fist, 10c; 1/ oz, 35c; oz, 60c; $1 / 4$ lb, $\$ 1.75 ; 1 \mathrm{~b}, \$ 5.25$, postpaid. Not prepaid, $5 \mathrm{Ibs}, \$ 24.00$.

718 Golden Ponderosa. (125 days). Similar to Ponderosa but yellow in color. The two sliced together make an attractive dish. Pkt, 15c; $1 / 2$ oz, 65c; oz, $\$ 1.00 ; 1 / 41 \mathrm{~b}, \$ 2.75$, postpaid.

730 Yellow Pear. (100 days). Largely used for making fancy pickles, preserves, marmalades, etc. Small, pear-shaped fruits are produced in enormous quantities on the vines. Vines make a very rank growth. Pkt, 10c; $1 / 2$ oz, 35c; $0 z, 60 \mathrm{c} ; 1 / 41 \mathrm{~b}, \$ 1.70$, postpaid.

"Please mail -..- June Pink Tomato Seed. This is special for Mr. ..... who has been planting seed which you shipped me for the past few years, and he refuses to plant any other, unless you are entirely out." ....... Rio Hondo, Texas.

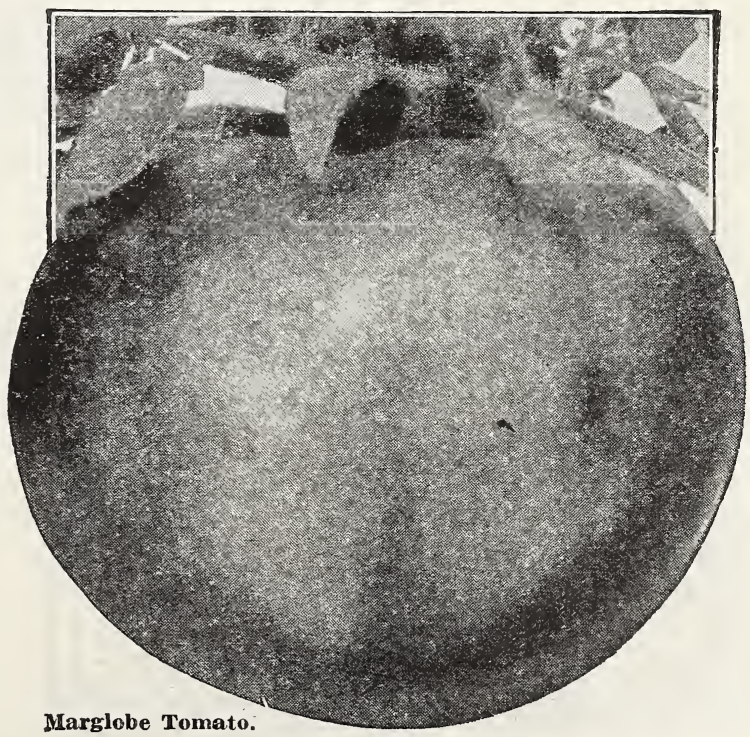

Marglobe Tomato. 


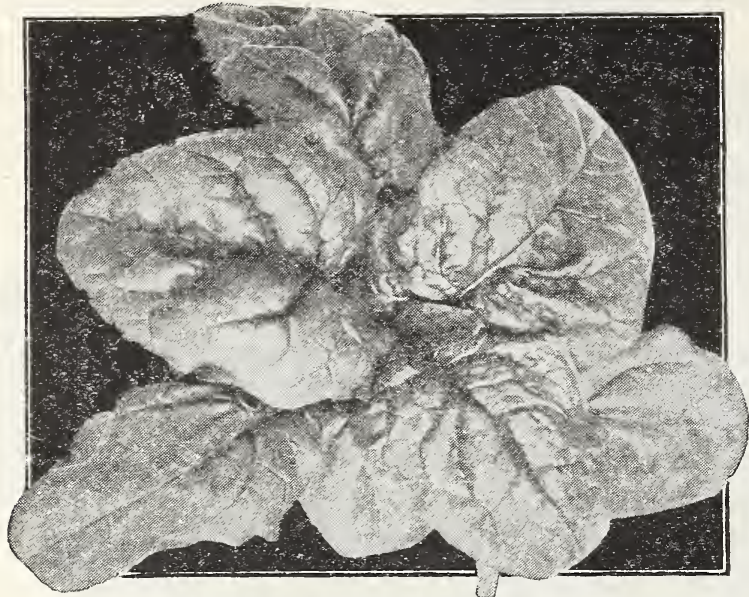

Mountain Evergreen Spinach.

\section{Spinach}

Weli established as a valuabie item in the diet. Makes palatable and nutritious greens and can be had both spring and Fall.

Culture. One ounce will sow 100 feet of drill; 10 to 12 pounds per acre. Seed should be sown very early in the spring and every two weeks until June A fine Fall crop can be raised by planting August 1 st to 15 th. New Zealand Spinach can be used in the Summer and Fall months. For early Spring use sow the regular varieties in the Fall, and where the Winters are severe protect the plants with leaves or straw. Plant in rows a foot apart and thin out when leaves are an inch wide. Spinach likes cool, moist weather and will become tough and go to seed in hot weather.

684 King of Denmark. (45 days). A long standing type with exceptionally large leaves. Leaves are slightly crumpled and have round edges. Color dark green; short leaf stalk. Pkt, 5c; oz, 10c; $\$ 1.50 ; 251 \mathrm{bs}, \$ 5.00$

6EO Iarge Virofiay. (55 days). Desirable for canning as the leaves grow clean and upright. Light green leaves are very large, broad and edges pointed at bottom. Pkt, 5c; oz, 10c; 1/4 1b, 15c; 1b, 40c, postpaid. Not prepaia, $51 \mathrm{bs}, \$ 1.35 ; 25 \mathrm{lbs}, \$ 5.25$.

679 IIJuntain Evergreen. (50 days). An improved type of Long Season Spinach. The bisexual plant selection has been developed in the Mountain Evergreen so that it remains tender and in excellent market condition long after all other early varieties have gone to seed. The inedium sized leaves are rosette-shaped, and nicely crumpled in the color is an intense dark green. Pkt, 10c: 0z, 15c; $1 / 41 \mathrm{~b}, 25 \mathrm{c}$; 1b, 65c, postpaid. Not prepaid, $5 \mathrm{lbs}, \$ 2.00 ; 251 \mathrm{bs}, \$ 8.00$.

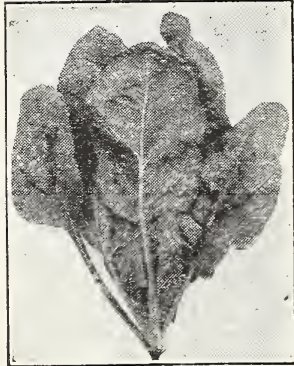

Flanders Broad. Leaf Spinach. 683 Bloomsdale. (40 days). Savoy or crumpled leaf type and the earliest of all Spinaches. Plant is hardy and excellent for late Fall planting for Spring use. Goes to seed quickly color, are heavily crumplied and have a short leaf stalk. Pkt, 5c; oz, $10 \mathrm{c}$; $1 / 41 \mathrm{~b}, 15 \mathrm{c}$; $1 \mathrm{~b}, 35 \mathrm{c}$, postpaid. Not prepaid, $\$ 5.25$.

677 Jong Standing Bloomsdale. (40 days). Stands two weeks longer than Bloomsdale before going to seed. Developed by selecting the bi-sexual plants. Fkt, 5c; oz, $10 \mathrm{c}$ $1 / 1 \mathrm{~b}, 20 \mathrm{c} ; 1 \mathrm{~b}, 45 \mathrm{c}$, postpaid. Not prepaia, 5 lbs, $\$ 1.50 ; 25$ Ins, $\$ 6.00$.

681 Flanders Eroad Ieaf. (55 days). Another fine canning variety, washing perfectly clean. Similar to viroflay but with rounded bottom edges. Very large, broad leaves. Plrt, 5c; oz, 10c; $1 / 41 \mathrm{~b}$, 15c; $16,35 \mathrm{c}$, postpaid. Not prepaid, $5 \mathrm{lbs}, \$ 1.50 ; 25 \mathrm{lbs}, \$ 6.00$.

676 Princess Juliana. (55 days). One of the finest late types, a long standing Spinach of very attractive appearance. Dark green leaves are blistered and crumpled and hold up well in shipping. Prt, 5c; oz, 10c; 1/4 1b, 15c; 1b, 50c, postpaid. Not prepaid, $5 \mathrm{lbs}, \$ 1.50 ; 25 \mathrm{lbs}, \$ 6.00$.

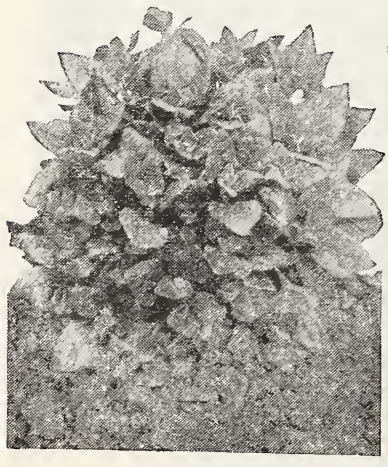

New Zealand spin:ch.
678 New Zealand. (60 days). A distinct everbearing type. Taller plants of branching type can be cut again and again all Summer, bearing a fine crop in the hot test weather. Plant after ground has warmed, in hills 18 inches apart, thin to one plant to the hill. Soak seed in lukewarm water for 12 hours before planting. Pkt, 5c; oz, 10c; $1 / 41 \mathrm{~b}, 30 \mathrm{c} ; 1 \mathrm{~b}, 90 \mathrm{c}$ postpaid. Not pre$=510$ s, $\$ 13.25$.

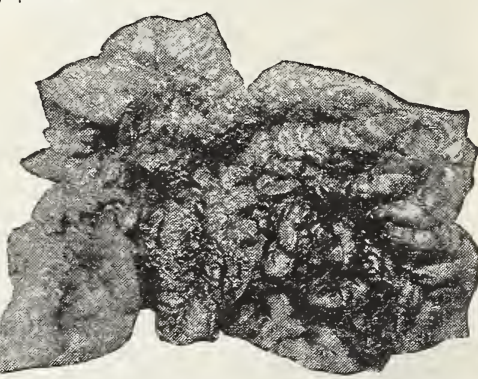

Long Standing Bloomsdale Spinach.

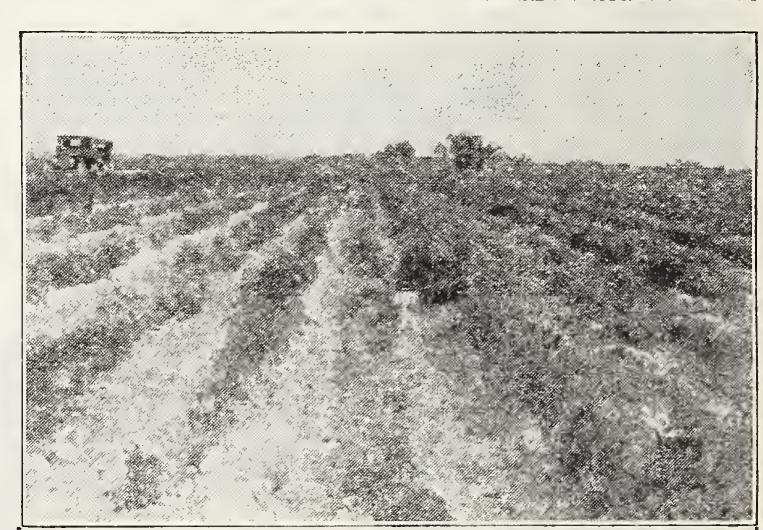

Tomato plants all fertilized alike except plants at right which received in addition a small amount of

\section{Manganese Sulfate}

Replaces manure when used with regular ritrogen, prosphorus, and potash commercial fertilizer. Increases crop yields, hastens maturity, nroduces quality crops, and assists to prevent Chlorosis, "Yellows."

Testing sample of Manganese Sulfate and reprints of articles on its use and application will be sent on request without charge.

\section{Write today}

CARUS CHEMICAL CO., Inc. Sta. A-1, Ia Salle, In.

Manganese

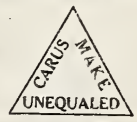




\section{Turnips}

Turnips are a delicious and non-fattening fibrous food. Turnips are easily and cheaply grown, they make an excellent feed to keep stock in good shape.

Culture. One ounce sows 125 feet of drill. In drills 12 to 15 inches apart use two pounds per acre, broadcast three to four pounds per acre.

A loose, light, rich soil is best to mature Turnips rapidly and to avoid any check in growth. The bitterness in some Turnips is caused by checking the growth. Turnips thrive best in the cool months of the Spring and Fall. Sowings should be made in the Spring crop should be planted as early as the ground can be worked, the young Turnips can be used in thinning the crop. Thin to 6 to 8 inches apart in the rows. Cultivate often and thoroughly.

734 Farly White Flat Dutch. (55 days). Grows quickly. Has clear white skin, juicy flesh, and mild favor. Best for table use when about three inches in diameter. Medium sized, flat variety. Plkt, 5c; oz, 10c; 1/4 1b, 25c; 1b, 80c, postpaid. Not prepaid, 5 lbs, $\$ 3.25$.

738 Extra Early Purple Top Milan. (50 days). The earliest Turnip in cultivation and an excellent variety for your early crop. The quality is fine, very smooth skin and more transparent than any other sort. Best in quality when about 2 inches in diameter. Very flat, small tops, roots of medium size, with a bright purple top. Fist, 10c; oz, $20 \mathrm{c} ; 1 / 41 \mathrm{~b}, 35 \mathrm{c} ; 1 \mathrm{~b}$, $\$ 1.00$, postpaia. Not prepaid, 5 lbs, $\$ 4.25 ; 25$ 1bs, 18.75 .

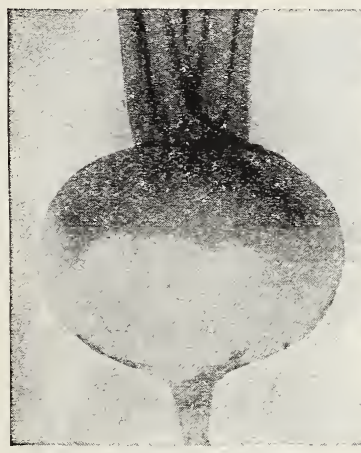

Purple Top White Globe.

739 Extra Early White Milan. (52 days). Similar to Purple Top Milan but roots are solid clear white. Pkt, 10c; oz, 20c; 1/4 1b, 35c; Ib, $\$ 1.00$, postpaid. Not prepaid, 5 lbs, $\$ 4.25 ; 25$ ibs, $\$ 17.00$.

740 Purple Top Strap Ieaf. (65 days). An early variety, very extensively used as a table Turnip. A quick grower with very fine grained and sweet flavored flesh. Best for table use when 2 to 3 inches in diameter. Of uniform growth, very flat, quite smooth and with a bright purple top. An excellent keeper, and used both for table and stock. Pkt, 5c; oz,
$1 \mathrm{~b}, 70 \mathrm{c}$, postpaid. Not prepaid, 5 lbs, $\$ 2.75 ; 25 \mathrm{lbs}, \$ 11.25$.

735 Purple Top White Globe. (70 days). The handsomest and most popular market variety. An excellent main crop variety, keeps well in storage. Large, rapid growing sort, with globe-shaped roots, lower portion white and top bright purple. Flesh pure white, fine grained and fine flavor. Best for table use when three inches in diameter, but can be grown much larger. Our strain of this variety has been carefully selected and is very uniform. Pkt, 5c; oz, 10c; 1/4 1b, 25c; 1b, 75c, postpaid. Nct prepaid, 5 lbs, $\$ 3.00$; 25 los, $\$ 12.50$.

733 Ward's Gem. (55 days). Very fine flavor and one of the best to sow very early in the Spring. The round roots are pure white and have an attractive appearance. The flesh is fine grained and of excellent flavor. The Turnips have a smooth, white skin and are excellent for early market. Does not grow large. Flst, 10c; oz, 15c; 1/4 1b, 35c; 1b, \$1.10, postpaid. Not prepaid, $5 \mathrm{lbs}, \$ 4.75$.

742 Improved White Egg. (65 days). Egg-shaped, pure white Turnips, good for either Spring or Fall sowing. Flesh is firm, sweet and mild, in best table condition when about $11 / 2$ inches in diameter. Grows to a large size, yields well and keeps a long time in storage. Pht, 5c; oz, 10c; 1/4 10, 25c; ib, 75c, postpaid. Not prepaid, 5 lbs, $\$ 3.00 ; 25 \mathrm{lbs}, \$ 12.50$.

737 Golden Ball. (75 days). A yellow Turnip grown extensively in home gardens because of its fine quality. Medium size, round roots of very fine

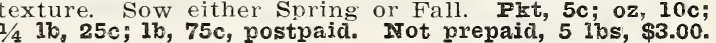

744 Pomeranian White Globe. (85 days). A very productive variety, if grown in good, rich soil prots will often grow to weigh 10 to 12 pounds. Used for stock feeding, and is also good for table use if pulled when young. Roots are a slightly flattened globe shape; skin very white and smooth. Pkt, 5c; oz, 10c; $1 / 4$ ib, 20c; ib, 60c, postpaid. Not prepaid, 5 1bs, $\$ 2.50$; 25 1bs, $\$ 11.00$.

743 Irong White Cowhorn. A great field Turnip and very desirable for stock feed. This variety is also widely used as a green manure crop and turned under to improve the soil. The roots are carrot-like in form, 12 inches long by $21 / 2$ inches in diameter. They grow about 3 inches out of the cround, are clear white except a small green top. When young, the flesh is fine grained and good flavor. Pkt, $5 \mathrm{c}$; 0z, 10c; $1 / 41 \mathrm{~b}, 25 \mathrm{c}$; 1b, 75c, postpaid. Not prepaid, 5 lbs, $\$ 3.00$; $25 \mathrm{Ibs}, \$ 12.00$

747 Seven Top. Grown extensively for the leaves which are cooked like spinach. Also used for canning. Seven Top is also used like Rape for a pasture crop. Does not form an edible root. Very hardy and grows through the Winter in mild climates. Plt, $5 \mathrm{c}$; oz, $10 \mathrm{c} ; 1 / 4 \mathrm{lb}, 20 \mathrm{c}$; $1 \mathrm{~b}, 60 \mathrm{c}$, postpaid. Not prepaid, 5 Ibs, $\$ 2.30$; $251 \mathrm{los}, \$ 10.25$.

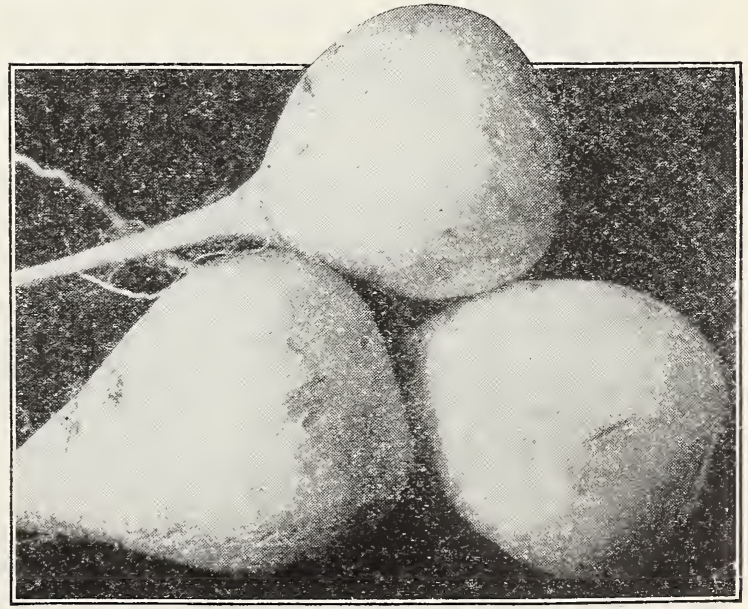

Improved White Egg Turnips. 


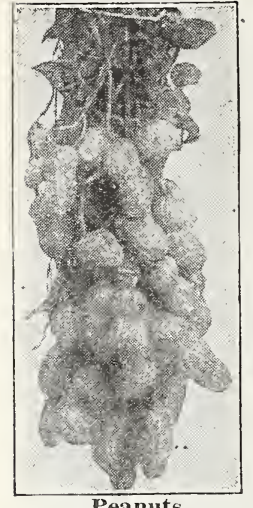

Peanuts.

\section{Peanuts}

Grown both for the nuts and for the hay.

Culture. 40 pounds per acre. Plant in a light, sandy soil. Plant in rows 3 feet apart and about 10 inches apart in the rows.

217 Small Spanish. Very early. $1 / 21 \mathrm{~b} ; 35 \mathrm{c} ; 1 \mathrm{~b}, 50 \mathrm{c}$, postpaid rot prepaid 10 lbs., \$3.25. 218 Iarge Virginia. Large pods. $1 / 21 b, 35 c ; 1 b, 50 c$, postpaid. ITot prepaid, 10 lbs, $\$ 3.25$.

\section{Salsify or Oyster Plant}

Oyster flavor, used in soups or may be boiled or sliced and fried.

Culture. One ounce to 50 feet of drill. Sow early and quite deep in a light, rich soil. Very hardy, can be stored or left in ground all Winter.

675 Mammoth Sandwich Islana. Largest and best quality. Plrt., 5c; oz, 20c; $1 / 4$ ib. 60 ; 1b., \$1.80, postpaid.

\section{Ideal Sprayer}

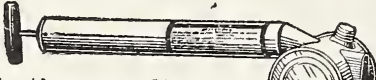

For disinfecting poultry houses, spraying vines and shrubbery, applying fly chasers to animals, etc. Length 20 inches, capacity one quart. Price, 55c, postpaid.

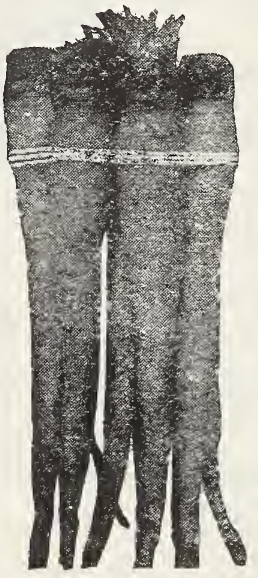

Salsify.
Rhubarb or Pie Plant

For Rhubarb Roots, see page 48 .

An early Spring vegetable and a real Spring tonic. Rhubarb leaves should not be used for greens or fed to stock, they are poisonous.

Culture. One ounce to 150 feet of row. Sow seed in a shallow drill. The stalks should not be used until the plants have had a full season's growth. When a blossom stalk appears it should be cut back well into the ground to prevent the plant from running to seed. 673 IMammoth. Vigorous and productive stalks fully $11 / 2$
Rhubarb.

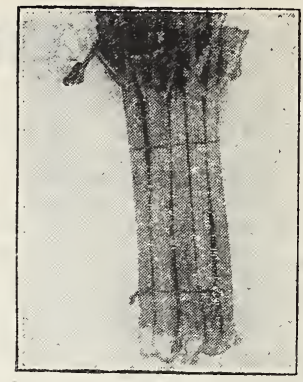
inches wide and bears for a long season. Pikt., 10c; Oz., 25c; 1/4 1b., 75c; 1b, \$2.30, postpaid.

\section{Rutabagas or Swede Turnips}

Large winter Turnips with a fine sweet flavor

Culture. The same as Turnips except that Rutabagas require a longer season for maturing and should be sown the latter half of Junte.

748 Improved American Purpie Top. (95 days). A hardy, productive variety; roots are large, with a very small tap root. Color bright yellow with a purple top. Plst, 5c; oz, 10c; 1/4 1b, 25c; 1b, 75c, postpaid. Not prepaid, 5 Ibs., $\$ 2.50$.

749 Bangholm. (100 days). One of the best and heaviest cropping sorts. The quality is fine; very tender, and without the stringy nature common in some sorts. A valuable table variety, and is also used for stock feeding. An excellent keeper. Globe shape, with a rich purple top and light yellow below ground. Pkt, 5c; oz, 10c; 1/4 1b, 30c; 1b, 85c, postpaid. Not prepaid, 5 lbs, $\$ 3.50$; $10 \mathrm{lbs}, \$ 6.25$.

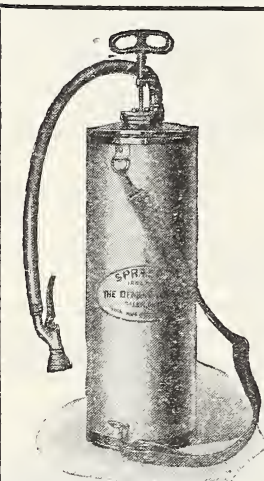

\section{Deming Sprayers FOR SATISFACTORY SERVICE}

Fig. 1669 Bucket Sprayer. Double acting. Made entirely of brass rest. High pressure is developed and the pump is well balanced foot always primed. May be used with any bucket or even a shallow container. Easy to clean and store. Shipping weight about six pounds. (Price, \$4.00, not prepaiá).

Fig. 1663 Compressed Air sprayer. Seamless brass pump two seamed, closely rives in diameter. Capacity tank, four gallons. Double and two-foot brass extension rod regularly furnished. Shipping weight about eleven pounds. Price, with galvanized tank, $\$ 6.70$, not prepaid.

rig. 1663. Price, with brass tank, $\$ 9.90$, not prepaid.

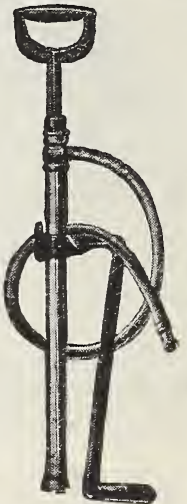

Fig. 1669

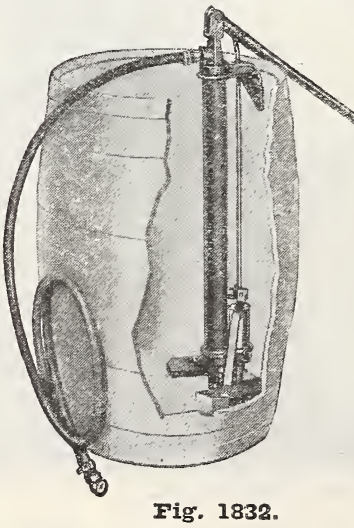

Fig. 1002 Knapsack Sprayer. gallons. Extra heavy tank bottom. Cylinder below tank bottom always primed. Continuous high pressure developed with slow easy pumping. Automatic shut off cock controls iow of material. Shipping weight about thirty pounds. Price, with galvanized tank, \$14.25, not prepaid. Price, with brass tank, \$18.55, not prepaid.

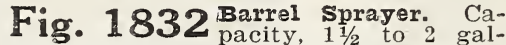
lons per minute. All internal working parts of brass. Adjustable for any height of barrel. Develops high Price, pump only, \$10.70, not prepaid.

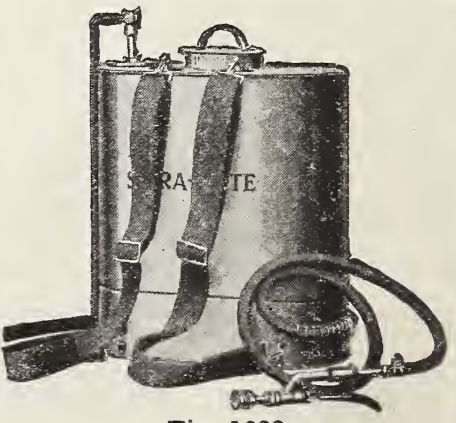

Fig. 1002. 


\section{Strawberry Plants}

Strawberries are one fruit that everyone should raise. Soil previously grown to root crops is well adapted to strawberries.

The best time to plant strawberries is from the first of April to the midale of May.

Our plants are fresh, Spring dug-dug as shipped. Shipped from the mountain nursery. Shipping weight, 35. lbs. per 1000 .

PROGRFSSIVE RVERBEARING. Good yielding and one of the first successful everbearing strawberries introduced. Plants, 25 for $\$ 1.10 ; 100$ for $\$ 3.20$, postpaid. Not prepaid, $\$ 15.00$ per 1000 .

PROGRTSSTVF FVERBEARING STRATRFRRY SFFD. Pkt., 10c: 3 pkts., 25c, postpaid.

SUPRRB EVBRBEARING. Fruit red and of excellent quality. Fruits heaviest in late Summer and Fall. Plants, 25 for $\$ 1.10 ; 100$ for $\$ 3.20$, postpaid. Not prepaid, \$15.00 per 1000 .

SUPREME EVRRBFARING. Shortage of plants, can not offer this season.

MASTODON EVERBEARING. Heavy yielding, big berries that top the market; read what a customer says: "Enclosed find check for Mastodon Strawberries. I am very well pleased with those I got last Spring. They beat any kind I have had. About one-half of the two dozen I got are full of runners and berries. The first strawberries I ever had that had to be sliced up. I've been used to strawberries for over 68 years. The Mastodon is my strawbrry." -W. H. Vela, Jackson, California.

Order a few now and be convinced of the true worth of Mastodon. Plants, 12 for $\$ 1.10 ; 25$ for $\$ 1.60$; 100 for $\$ 4.20$, postpaid. Not prepaid, $\$ 20.00$ per 1000 . MARSFATI. Large, dark rich crimson of very good quality. The leading commercial variety. Plants, 25 for $75 \mathrm{c}$; 100 for $\$ 1.90$, postpaid. Not prepaid. $\$ 10.00$ per 1000 .

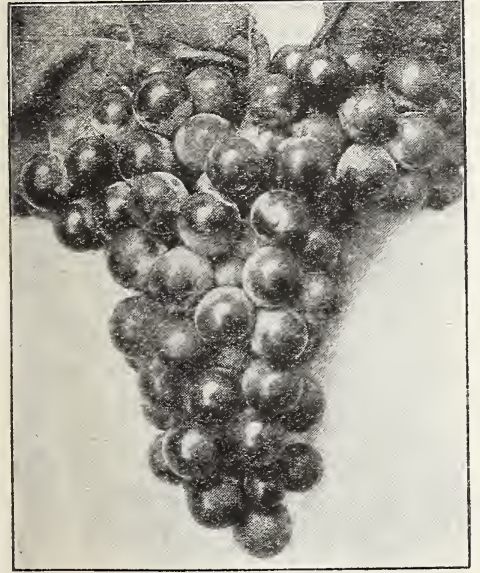

Concord Grapes.

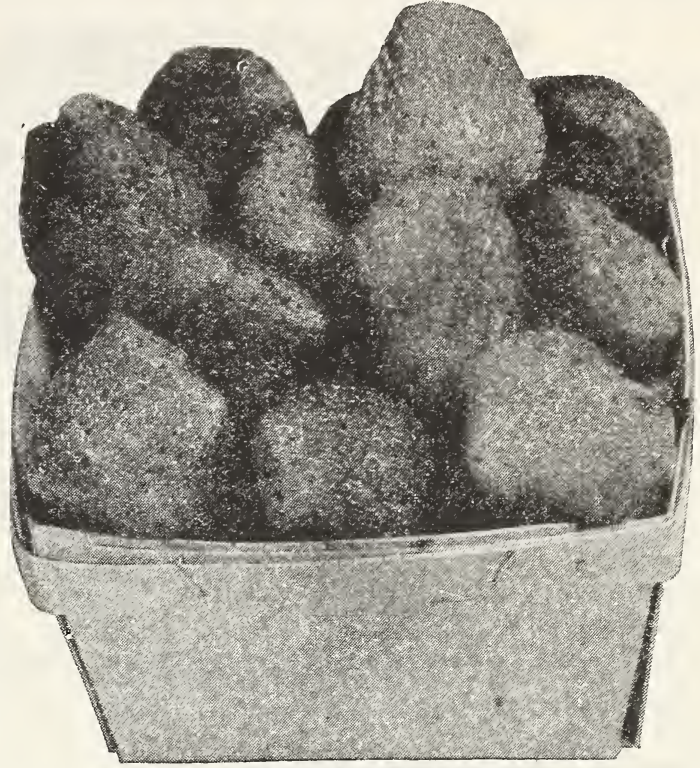

Mastodon Strawberries.

BIG IATE. Yields twice as heavily as Marshall, the berries are much larger, the flavor is far better and the color is a luscious glistening red. Big Late Strawberries are excellent for shipping. Plants, 25 for $\$ 1.60 ; 100$ for $\$ 3.70$, postpaid. Not prepaid, $\$ 17.50$ per 1000 .

\section{Small Fruits}

These are thrifty, hardy, vigorous plants. Shipped direct from the mountain nursery. Shipping weights, 1 lb. for 1 plant, 5 lbs. for 10 , 35 lbs. per 100 .

CURRANTS, Fay's Prolific. A leading market currant. Extra large berries. Uniform in size and easily picked. 2-yr. No. 1 plants, 30c each; 10 for $\$ 2.50$, not prepaid.

DEW BERIES, Iucretia. Large jet black, highly flavored and hardy. A profitable market sort. Strong No. 1 plants, 15c each; 10 for $\$ 1.00$; 100 for $\$ 8.00$, not prepaid.

DEWBERRIES, Thornless. Enormous, big, luscious berries, almost seedless and of very distinctive flavor. Strong No. 1 plants, 30c each; 10 for $\$ 2.50 ; 100$ for $\$ 15.00$, not prepaid.

GOOSFBERTIRS, Downing. A large, handsome, pale green berry of splendid quality. Good for both cooking and table use. Strong 2-year plants, 30c each; 10 for $\$ 2.50 ; 100$ for $\$ 15.00$, not prepaid.

GRAPES, Concord. A black grape; the leading market, vineyard and home garden variety with which all others are compared. 30 c each; 10 for $\$ 2.50 ; 100$ for $\$ 15.00$, not prepaid.

GRAPES, Muscat. The renowned raisin and table grape. 40c each; 10 for $\$ 3.30$, not prepaid.

GRAPFS, Zinfandel. Widely used as a wine grape. Borne in compact clusters; flesh abundant, juicy, and of a good flavor. $40 \mathrm{c}$ each; 10 for $\$ 3.30 ; 100$ for $\$ 20.00$, not prepaid.

RASPRERRIFS, Cuthbert. Large conical, rich crimson, excellent quality. Strong No. 1 plants, $15 \mathrm{c}$ each; 10 for $\$ 1.25$, not prepaid.

RASPBERRIRS, st. Regis. The everbearing red, very prolific. Strong No. 1 plants, $20 \mathrm{c}$ each; 10 for $\$ 1.65$, not prepaid.

BIACK RASPBERIIES, Cumberland. One of the earliest to ripen, excellent quality. Strong No. 1 plants, $20 \mathrm{c}$ each; 10 for $\$ 1.65$, not prepaid.

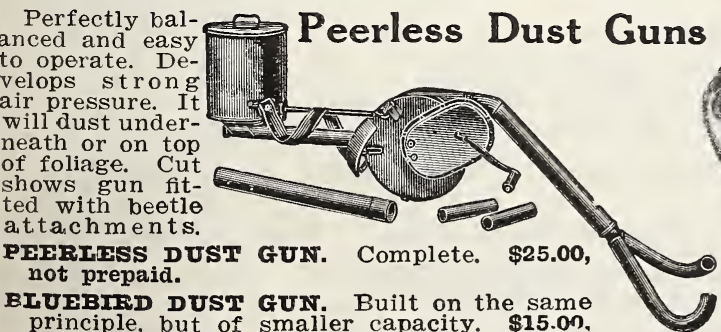

principle, but of smaller capacity. \$15.0n.

not prepaid.

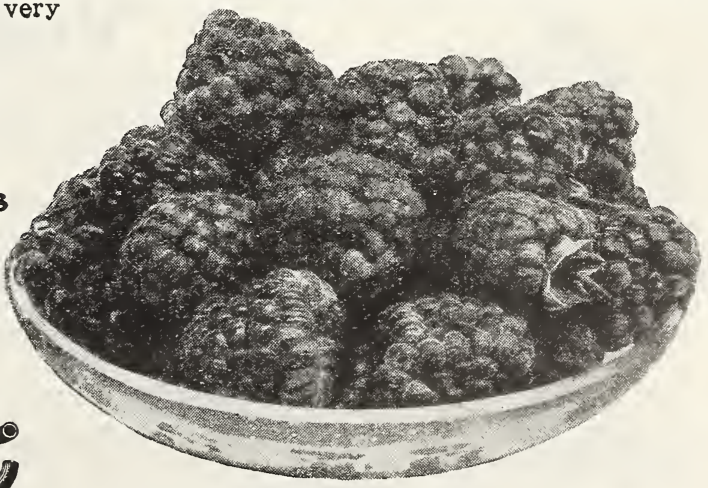

Cuthbert Raspberries. 


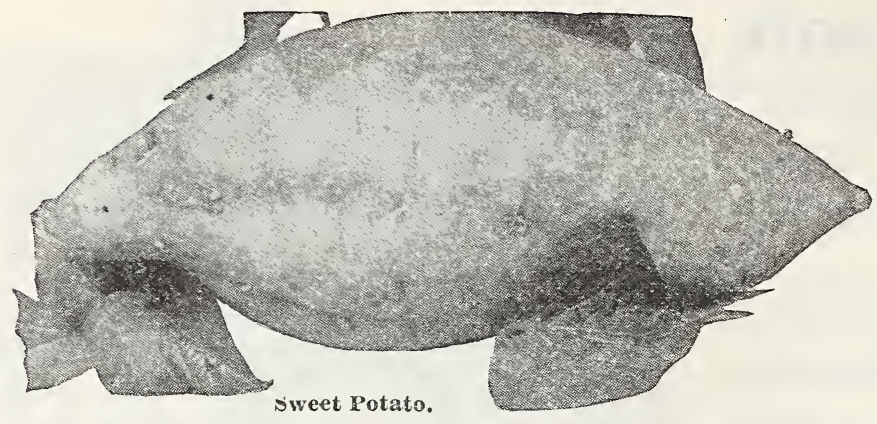

\section{Vegetable Plants}

Mountain Grown, Transplanted Vegetable Plants, With a Real Root Growth. Sturdy plants that will grow. These plants are all grown from the finest varieties of seeds.

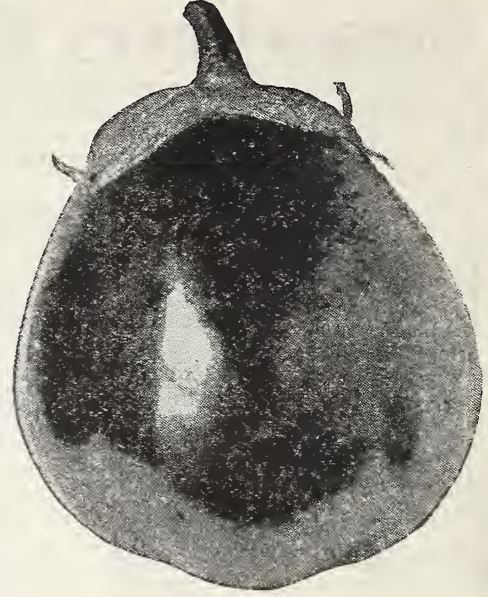

Eggplant.

We Guarantee Delivery of Plants to the Second Zone Only, and do not recommend the shipping of plants beyond the third zone, excepting onion plants. Onion plants are listed on page 30.

Send your plant order with your seed order and we will be more certain of having the varieties you want ieady for you.

Specify Date You Want Plants Shipped and weather permitting, we will ship on that date.

Order Iarge Quantities Shipped by Express. Shipping weight per 1000 plants about 40 pounds. We Do Not Ship Plarts C. O. D.

CABBAGE. Farly. Ready

April 1st to May 19 th.

Copenhagen Market,

Earliest of All, Early

Jersey Wakefield, Gold-

en Acre, Stein's Early

Flat Dutch ......... \$0.30 $\$ 0.75 \quad \$ 1.20 \quad \$ 9.00$

CABBAGE. Iate. Ready

May 20 th to July 15 th.

Copenhagen Market,

Danish Ballhead, Hol-

lander, Mountain Ball-

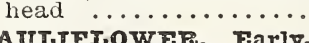

Ready April 1st to May

19 th. Special Strain

Danish Snowball, Dry

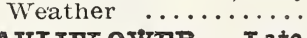

CAUIIFEOWRR. Iate.

Ready May 20th to

July 15th. Special

Strain Danish Snow-

vall, Dry Weather ...

CEIERY. Early. Ready

April 15th to June 14 th

Extra Early Tall

Golden Self Blanching,

Golden Plume, Golden

Self Blanching ......

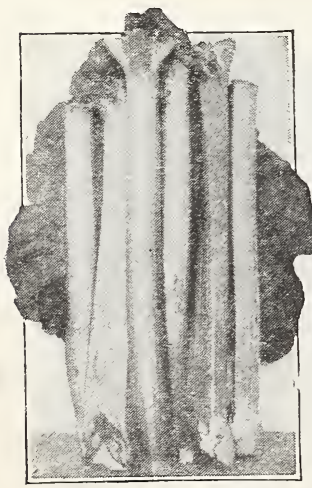

Mammoth Rhubarb.

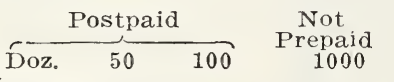

$.20 \quad .45 \quad .70$

4.50

$\begin{array}{lll}.35 & .85 & 1.30\end{array}$

10.00

$.20 \quad .60 \quad .85$

5.50

$.25 \quad .75 \quad 1.15$

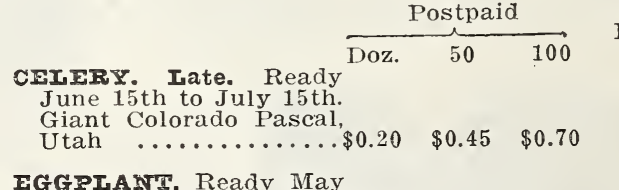

Not Prepaid 1000

$\$ 4.50$

1st to June 15 th Black Beauty, New York $\ldots \begin{array}{llll}1 . .35 & .85 & 1.30 & 10.00\end{array}$

PFPPER. Ready May 1st to June 15 th. California Wonder, Chinese Giant, Early Mountain, Ruby Giant, Sunnybrook, Worldbeater Cayenne ............

TOMATO. Ready April 15 th to July 1st. Bonny Best, Earliana, John Baer, June Pink, Marglobe, Peerless Pink, Ioneymaker, Ward's $\mathrm{J}$ u $\mathrm{m}$ b o, Ponderosa, Yellow Pear ........

SWFET POTATO. Ready May 1st to July 1st. Yellow Jersey, Nancy Hall, Yellow Nansemond $\ldots \ldots \ldots \ldots \ldots \ldots \ldots . .25 \quad .60 \quad 1.00$

\section{Vegetable Roots}

PATMETTO ASPARAGUS. A prolific type for the Mountain territory, where Asparagus is not bothered with lust. Plants, $35 \mathrm{c}$ per doz; 50 for $80 \mathrm{c} ; 100$ for $\$ 1.40$, postpaid. Not prepaid, $\$ 7.00$ per 1000.

MARY WASHINGTON ASPARAGUS. The best of the rust-resistant types developed by the United States Department of Agriculture. Grows large, with closely folded tips. Plants, 40c per doz; 50 for $90 \mathrm{c} ; 100$ for $\$ 1.75$, postpaid. Not prepaid, $\$ 8.00$ per 1000 .

HORSERADISI CUTYINGS. 50c per doz; 50 for $\$ 1.35$; 100 for $\$ 2.00$, postpaid.

HORSERADISI CROWIS. $\$ 1.30$ per doz, postpaid.

PHUBARB, Myatt's Victoria. Roots, 3 for 30c; 12 for 90c; 50 for \$2.75, postpaid. Not prepaid, \$4.50 per 100 .

REUBARB, Mammoth. Roots, 3 for $45 \mathrm{c} ; 12$ for $\$ 1.25$; 50 for $\$ 3.75$, postpaid. Tot prepaid, $\$ 5.50$ per 100 .

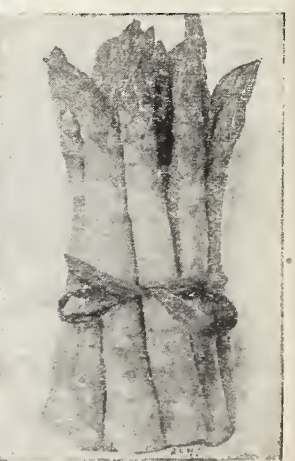

Asparagus, 


\section{CHANSE

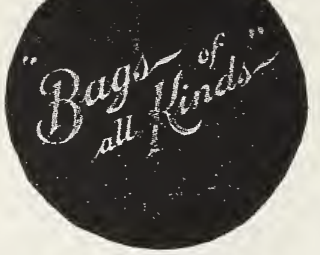 \\ IB A

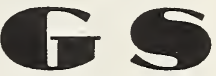 \\ Special Bags for Seed and Produce}

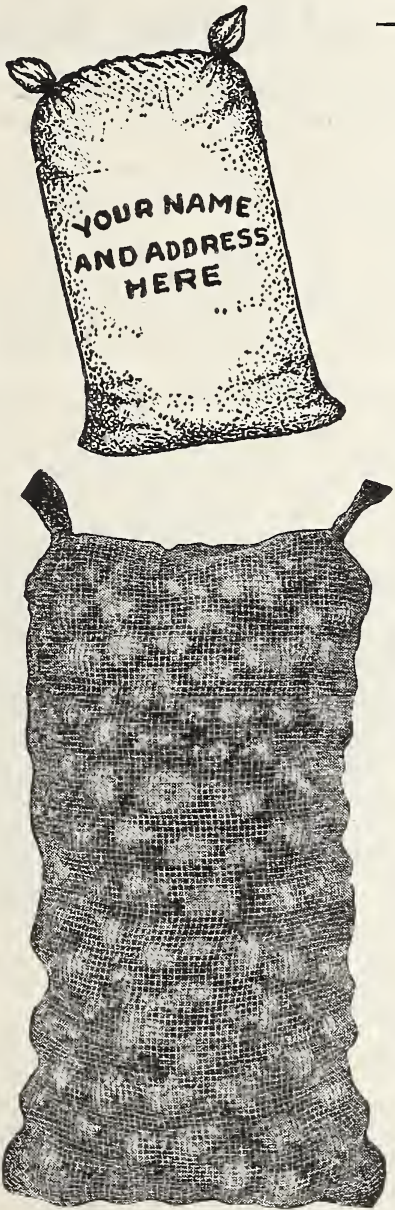

\section{Chase Seed Bags}

C) AKE your order read "Chase Seed Bags". Specify either drill, duck, osnaburg, sheeting canvas or burlap; printed or plain.

\section{Saxolin Open Mesh Bags}

A clean-cut, open mesh bag that gives perfect ventilation and visibility and displays contents from top to bottom. The standard container for onions, carrots, cabbage, potatoes and melons. Saxolin Bags win sales preference for your product and bring you highest market prices. Send for samples.

\section{CHASE SAXOLIN Waterproof Wrapping Papers} Ideal for conserving moisture in roots of shrubs, trees and plants while in transit and for covering seed during fumigation. There is a Chase Wrapper that will answer a grower's every requirement.

Write nearest Chase Branch or Sales Office for samples and prices.

\section{CHASE BAG CO.}

Branches: Milwaukee - Memphis - Goshen-St. Louis - Minneapolis·Buffalo - Kansas City - Toledo - New Orleans • Dallas Sales Offices: New York - Charlotte - Chicago - Denver Louisville

Cleveland-Detroit · Hutchinson'Little Rock - Charleston

Affiliated Company THE A DAMS BAG COMPANY, Chagrin Falls, Obio Manufacturers of NEVERBURST Paper Bags 


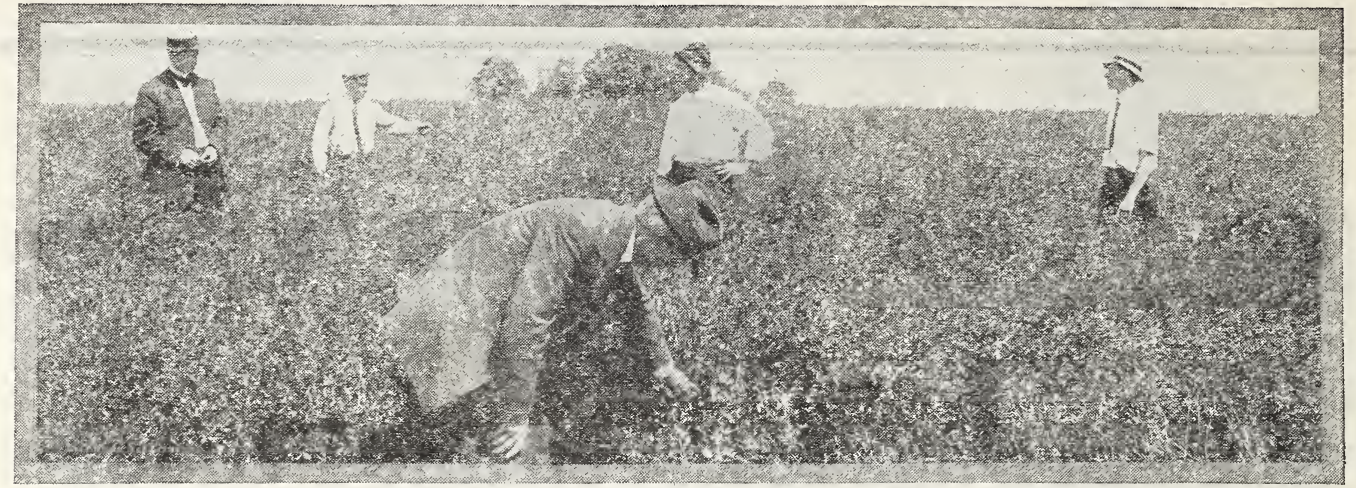

Three and Four Crops Like This Every Year.

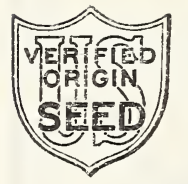

\section{U. S. Verified Origin Alfalfa Seed}

The United States Government Representative verifies the county and state of origin of all Alfalfa Seed we sell. The bags carry the U. S. Verified Origin tags and you get a cer-
tificate of origin with your seed. This is another regulation that protects the farmer from non-hardy seed.

Valuakle Book Free. The I. H. C. extension department has published a valuable book on Aifalfa. This book tells what soils are adapted to Alfalfa, how to plant and care for an Alfalfa crop, and just all about Alfalfa. We have bought a supply of these bools for our customers, send two cents for postage and we will send your copy of the I. H. C. Alfalfa book.

Alfalfa yields the heaviest tonnage per acre of any hay crop; vielding 3 to 7 tons of the finest hay per acre each year. Alfalfa hay is very palatable and is relished by all classes of stock. This hay has 60 per cent more feeding value than Timothy. Alfalfa contains a higher percentage of protein, to build. muscle and bone, than any other feed produced on the farm. It is especially good for dairy cows. Alfalfa is a wonclerful soil builder. Land which has been in Alfalfa for a few years will always produce bumper yields

\section{Hardy Mountain Grown Seed that will tive and} Thrive in spite of Climatic Conditions.

Grand Junction is located in the heart of the Alfalfa seed producing section of Colorado. All of our Alfalfa seed, with the exception of the Turkestan, is strong, hardy, Mountain Grown Seed. We ship many carloads of Alfalfa seed each year from Grand Junction to seed houses in the east and north. In going which can be cleaned up for our Mile High grade. These lots are carefully set aside and held for our These lots are carefully set aside and held for our Mile Irigh seed, for we know the fields it came from. Many of these fields have been successful in enduring our severe mountain weather for twenty years or nore.

Colorado Mountain Alfalfa. This seed belongs to the type known as Common Alfalfa. By nearly half a century of breeding in the mountains of this section f the country, where the climate is as severe in Winter as Montana or North Dakota, and extremely hot in Summer, this variety has become exceptionally hardy. It rarely winter-kilis, but grows tall and luxuriantly, thriving equally well on dry land as on irrigated soil, and yielding the heaviest crop per acre of any strain of Common Alfalfa. Mountain Grown Seed is exceptionally plump and well filled. The demand always exceeds the supply of this seed. Seedsmen clear to the Atlantic seaboard are it; although they could buy Argentine seed at a much lower price. If you intend to grow your Alfalia for the seed crops, we would rather recommend that you sow one of the improved varieties as the seed from it will always bring a higher price on the market. Or if your soil is very shallow, a spreading root type of Alfalfa will give you better satisfaction. But in the other cases, where the crop is wanted for hay, Colorado

See Colored Price Sheet for Current Prices.

\section{Grimm Alfalfa}

\section{Certified or Registered.}

Grimm Alfalfa was developed primarily for sections where there is a great deal of winter-killing. only one root, Grimm has a spreading root system. When the ground cracks With the freezing and thawing of Winter it is hardy crown of the piant also sets lower on the ground, so that it is less likely to be injured by stock.

Grimm is also valuable for sections where the water lies near the surface. The spreading roots of Grimm do not go down as deep as the Common, and standing water will kill Alfalfa.
Grimm makes a little finer stemmed hay than Common. Grimm does not require as much seed to the acre in planting, as the plants stool more.

Grimm Alfalfa is distinguished by the variegated colors of the blossoms, mostly blue shades. Yellow blossoms ocasionally appear, but not on all plants, especially during the first year.

Certified Grimm Alfalfa seed is a seed on which we hold the grower's sworn affidavit that only Grimm seed was sown in the field from which this seed was harvested. We furnish a certificate to this effect with each sale, on request. These fields are practically always inspected by our men to be sure that they are true Grimm.

Registered Seed is registered by the State College, and from fields inspccted by their representatives. If you intend growing your field for seed you should plant Registered Seed so that you can get your field registered. If you are growing your crop for hay, the ertified Seed will give you every satisfaction.

\section{Cossack Alfalfa}

Very similar to Grimm Cossack is claimed by some to be more hardy than Grimm. The original seed of this variety was brought from Siberia, but it has now been grown in this country for 15 or 20 years. See Colored Price Sheet for Current Prices.

\section{Turkestan Alfalfa}

Imported seed. The root system is short like Grimm. Turkestan is a light yielder of hay, but can be grown on shallow soils. It is used on these soils in preference to Grimm only because of its cheaper price. This imported Alfalfa has been blamed for introducing many noxious foreign weeds into the country. See Colored Price Sheet for Current Prices.

\section{Seed Staining Law}

This iaw applies to Alfalfa and Red Clover and the law was passed to protect the American farmer. The Bureau of Plant Industry of the United States Department of Agriculture has recommended that where severe Winter conditions prevail only American grown clover seed should be used. Our Alfalfas, Red Clovers and Sweet Clovers are not only American grown but also Mountain Grown.

To protect you against seed which is not hardy this imported seed must be stained. Seed wher country of origin is not known is stained red. Seed grown in Africa, Turkestan or Italy is stained red. Seed grown in Canada is stained violet. Seed grown in other foreion countries is stained green.

If you are in doubt follow the advice of the United States Iepartment of Agriculture and plant American grown seed, which is not stained. 


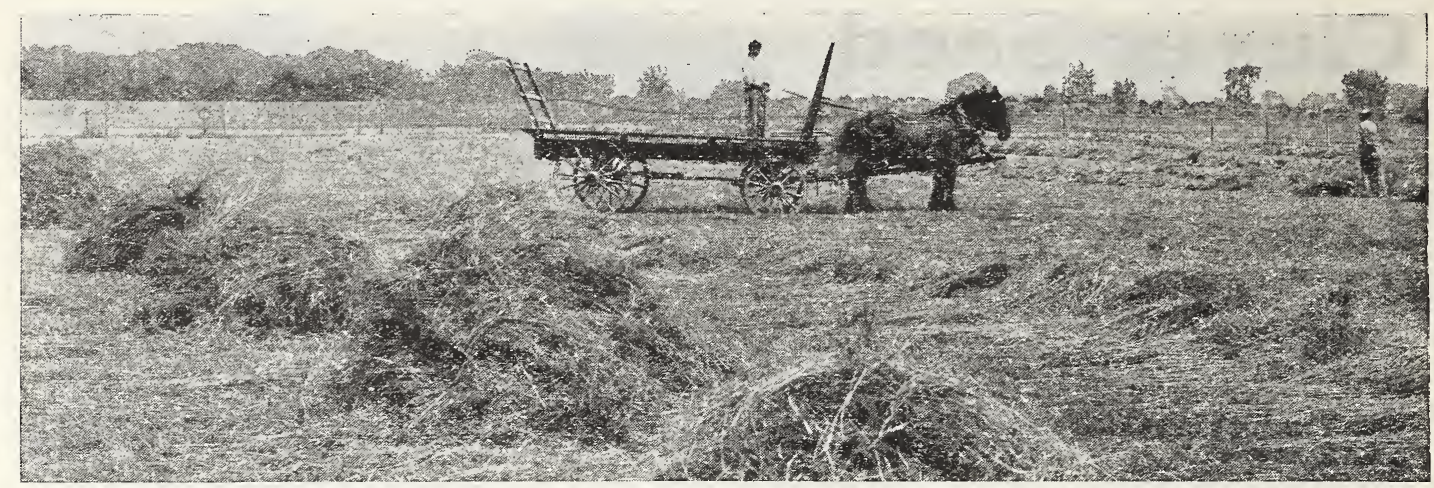

Meadows Grown From Our Superior Seed are Very Free From Weeds and a Good Stand is Assured

\section{Meadow Fescue (English}

Extremely hardy and the best drought resister of all. While used extensively in all sections, in the mountains, in the Middle West and on the Southern Plains, it is particularly adapted to clay and other heavy soils. It is a valuable grass on wet lands as it grows very rapidly and tends to keep down the coarser grasses which naturally grow in such places. Will thrive when trampled by stock, when Timothy and other grasses fail. Inclined to bunch unless sown thickly.

See Colored Price Sheet for Current Prices.

\section{Timothy}

Timothy is the old standard hay, and has been the most widely used for years. Timothy is the best hay for horses on heavy work, and there is no danger of giving the horse the scours. Timothy is cheap to plant, easily grown and of excellent quality. Thrives on clay and moist soils but not on poor or light land. Timothy flowers in July and should be cut when in full bloom, later the hay becomes hard and coarse. Cut Timothy 4 inches from the ground, as most Timothy is killed by mowing too close. Timothy should not be sown alone for pasture, but together with other grasses such as Meadow Fescue and Red Top.

See Colored Price Sheet for Current Prices.

\section{Alsike and Timothy Mixture}

A preferred mixture, especially where there is plenty of rainfall. Does well on most any land, but gives best results on moist lands. Alsike and Timothy make an excellent combination for hay and pasture; they are adapted to the same kind of soil and mature together. They are readily eaten by all stock. Both are very hardy, do not winter-kill, and when once established will live for years. Alsike and Timothy is the cheapest Clover and Grass Seed Mixture. The seed has been grown mixed and sells for less money than the two varieties separate.

See Colored Price Sheet for Current Prices.

\section{Pasture Mixtures}

There are many advantages in planting a mixture of grasses for a pasture. These grasses can be combined to give early, mid-season and late Fall pasturage. Some grasses are shallow rooted and some are deep rooted. Scme grasses are suited to irrigated soils, some to dry lands, and some to the very high altitudes. Various combinations are used under these different conditions, in each case to furnish the longest period of abundant pasture growth.

If you are at all in doubt as to the best mixture to

sow, write us, giving full particulars:
Your altitude?

Trrigated or not?

Time of usual rains?

Kind of soil?

Drainage, good or poor?

For Hay, Meadow or Pasture?

If for pasture, what kind of stock?

Is pasture wanted all Summer, or at a particular $\operatorname{time}$ of year?

Our Field Seed expert will be glad to write you fully on grasses suited to your needs.

Permanent Pasture, Dry Iight Soil. See Colored Price Sheet for Current Prices.

Permanent Pasture. Figh Altitude. See Colored Price Sheet for Current Prices.

\section{Morton's Special Mixture}

Mortou's Special Mrixture. For irrigated lands there is no better mixture of grasses. Prof. Morton of the Colorado Agricultural College spent 10 years experimenting to formulate this mixture. This mixture will carry more head of stock per acre than any grass or other mixture of grasses. Morton's special Mixture will pasture 15 to 20 cows per acre $41 / 2$ hours per day. Four to five days a month are 100 lbs. of Morton's Mixture contains:

30 lbs. of Orchard Grass.

30 lbs. of Brome Grass.

20 lbs. of Meadow Fescue.

12 lbs. of Timothy

8 lbs. of Yellow Blossom Sweet Clover.

We recommend this mixture in these exact proportions. Some of our customers object to the Sweet Clover in the mixture. The Sweet Clover adds protein to the mixture and there is not enough to harm any kind of stock, but for those who do not want the Sweet Clover we also make up the mixture without Sweet Clover

Morton's Mixture should be sown 30 to $40 \mathrm{lbs}$. to he acre.

See Colored Price sheet for Current Prices.

\section{Orchard Grass}

A very heavy hay yielder, richer than Timothy and outlives it. Often sown with Alfalfa to give a stronger and better hay. It will stand drought or will do well in the shade. Orchard Grass gives a heavy tonnage in permanent pasture, furnishes the first green bite in the Spring and the last in the Fall, is quick to recover from close cropping, and even thrives better the more it is cropped. Not suitable to extreme high altitudes.

See Colored Price sheet for Current Prices.

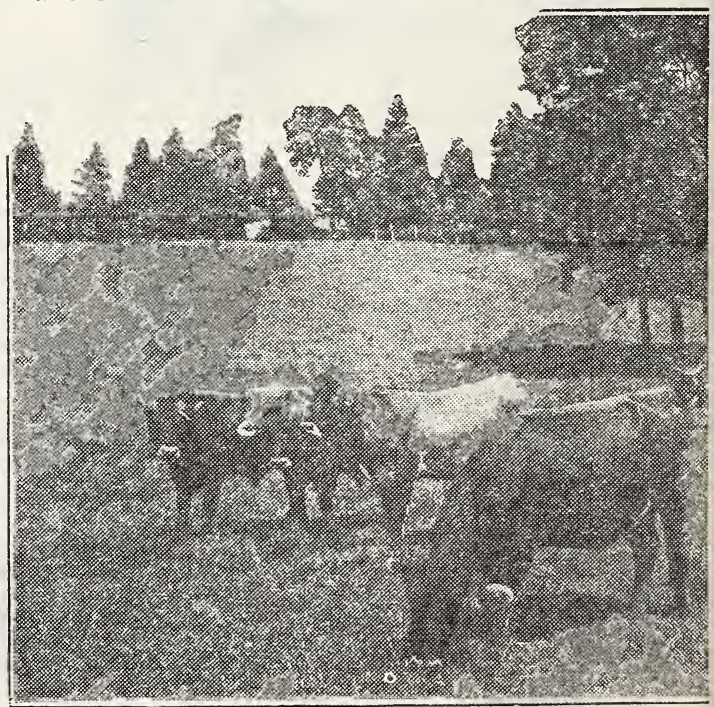

Grown From Our Pasture Mixture. 


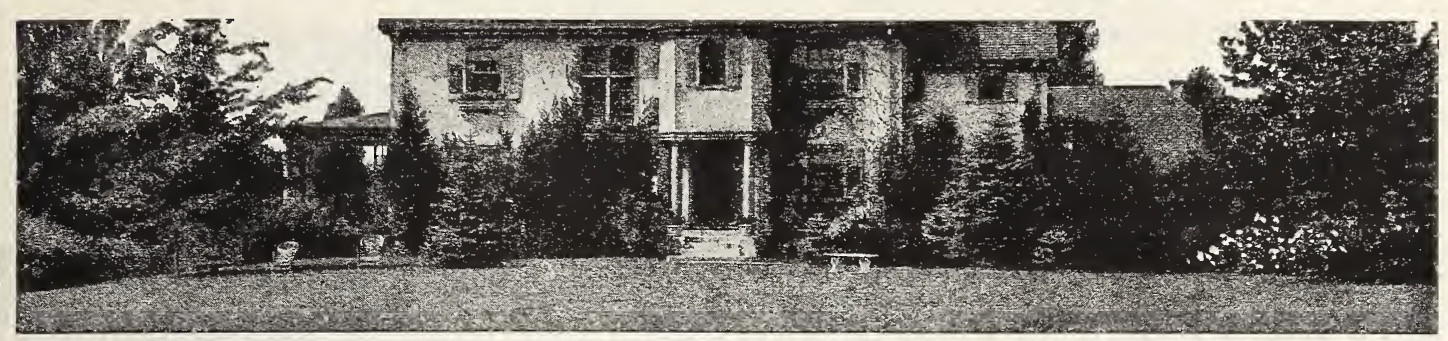

A Fine Lawn From Our "Mile High" Lawn Grass Seed.

\section{"Mile High" Lawn Grass Seed}

Contains the most beautiful grasses, a percentage of White Dutch Clover, and hardy grasses to protect the more tender grasses while they are becoming established.

"Mile High" Lawn Grass Seed is a carefully blended mixture, made from an exact formula, and backed by years of experimenting with both domestic and foreign grasses. It will form a thick, velvety turf with only a fair amount of care.

A mixture of 90 per cent Kentucky Blue Grass and 10 per cent White Dutch Clover makes a very beautiful lawn, but requires a great deal of care to establish.

For golf courses, public parks, school grounds, cemeteries, or difficult soil conditions, we will gladly make up special mixtures. Just tell us where you wish to plant and we will send the proper mixture of grasses. Or write us and our field seed specialist, Mr. Dessert, will be glad to write you fully.

TO MAKE A IAWN: If the soil is naturally rich merely spade and rake it as fine as possible. If the soil is poor a good dressing of manure or fertilizer should be spaded in first. For all ordinary conditions use "Mile High" Mixture Lawn Seed. Sow the seed at least one pound to every 300 square feet (10x30 feet). Thicker sowing will give a thick, velvet-like turf much quiler. If the weather is hot, branches until the grass is well established.

see Colored Price Sheet for Current Market Prices on "Mile Figh" Mixed Iuawn Grass.

Kentucky Blue Grass. The most desirable grass for lawns, and included in all good lawn grass mixtures. Our "Mile High" Lawn Grass contains a heavy percentage of Kentucky Blue Grass. Kendark green color. Very few people sow Blue Grass thick enough; for lawns it should be sown one pound for every 150 square feet, or for every plot 10 by 15 feet. A good pasture grass, starting to grow early in the Spring and continuing until See Colored Price sheet for Current Prices.

Rhode Island Bent Grass. Makes a fine turf of excellent color and adapts itself readily to any soils, particularly acid soils. Makes a beautiful lawn or a cood putting green for golf courses.

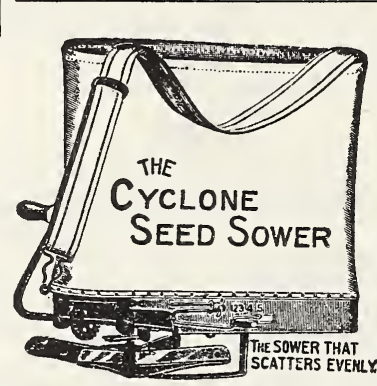

\section{Cyclone Seed Sower}

The finest hand seeder known. Built on up-todate and correct princiseed upward or against the operator, but direct and evenly on the land. Can be set to sow any
amount desired. Sows amount desired. Sows small grains very satisfactorily. Price, each, \$2.25, postpaid.

\section{"Mile High" Brand and "Mountaineer" Brand Field Seed}

Field Seeds carrying our "Mile High" Brand are not only grown from selected seed in selected fields and the seed saved only from selected crops, but in addition they are cleaned and recleaned and recleaned until only plump, well-developed seeds, free from chaff and foreign seeds, are left, then and only then can they wear our "Mile High" Brand. It will always pay you to plant "Mile High" Brand for the slight additional cost per pound of seed is made up many times over in your crop.

"Mountaineer" Brand is an excellent second grade at a price that will meet all competitive prices. While many would call it first grade seed it does not quite measure up to our "Mile High" standard. Some years on certain crops, through adverse weather conditions, it is impossible to produce seed which will grade "Mile High." We will be glad to send you samples of any or all grades on any field seeds in which you are interested.

Quantity of Seed Required per Acre and Customary Weights per Bushel.

Alfalfa, Common $\ldots \ldots \ldots \ldots \ldots \ldots$ Acre $10-12$

Alfalfa, Grimm

Australian salt Bush................. 1

Barley in

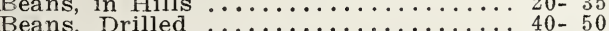

Beans, Drilled Bue Grass, for pasture................... $35-40$

Brome Grass, alone for hay .......... 18- 20

Brome Grass, for pasture ............ 20-25

Broom Corn f............ 5 - 8

Broom Corn, for seed.$\cdots \cdots \cdots \cdots \cdots 2_{25}^{5-30}$

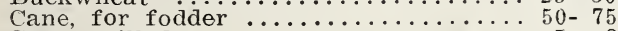

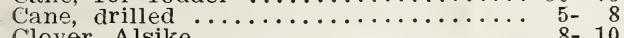

Clover, Alsike ..................... 8- 10

Clover, Mammoth Red ............ 8- 12

Clover, Medium Red .............. 8- 12

Clover, Sweet Biennial, Hulled ....... 12- 15

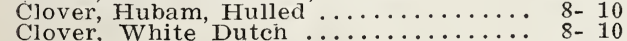

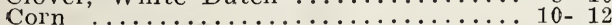

Corn, for silage .................. $30-35$

Feterita, drilled ................ 5- 8

Feterita, for fodder ............ 50-75

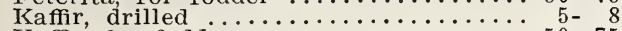

Kaffir, for fodder ................ $50-75$

Meadow, Fescue .................... 15- 20

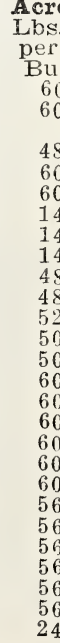

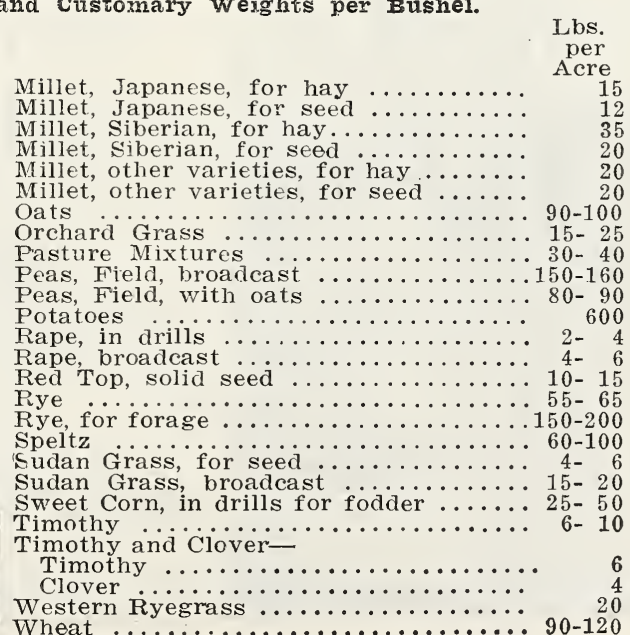

Lbs.

per

$\mathrm{Bu}$

35

50

50

50

32
14

Wheat .......................... 90 120 


\section{Brome Grass}

A heavy tonnage hay crop. Yields 1 to $4 \frac{1}{2}$ tons per acre of hay, about the same quality as Timothy. Hay should be cut at the time of full bloom. Stands drought among the best of the cultivated grasses and will also stand excessive moisture for a considerable period, or cold. Forms a leafy, compact turf that will stand severe pasturing. A wonderful grass for sheepmen for high ranges. Plant only where wanted permanently, as Brome is difficult to kill out.

See Colored Price sheet for Current Prices.

\section{Western Rye Grass}

Also called Slender Wheat Grass. Highly desirable for soils that contain some alkali. The Colorado Agricultural College finds Western Rye Grass most successful on these soils. Affords early pasture and first-class hay, being very nutritious. A drought resister and hardy under all conditions. Western Rye Grass will hold its place for years, if left alone, but one See Colored Price sheet for Current Prices.

\section{Zawadke Alkali Grass}

We are discontinuing this grass as so many of our customers have found it difficult to establish.

\section{Australian Salt Bush}

A valuable forage plant for reclaiming alkali soils. It seems to take the salty substance from the soil, and after 3 or 4 years make the land fit for other crops. It becomes parched by the heat in the late Summer, but stock will thrive on it, if forced by hunger to eat it. It requires no preparation of the soil for seeding on level land, but sloping land should have the surface broken. Sow in Spring or Summer when the soil is moist, after a rain. Do not cover the seed.

See Colored Price Sheet for Current Pxices.

\section{Red Top}

Produces best results on moist, rich soils, toms and such lands as may be flooded for some time in the spring. Adapts itself to a wide variety of soils. Used both as a permanent pasture grass and as a meadow grass for hay. Forms a dense, firm sod, able to withstand freezing and trampling of livestock.

\section{See Colored Price Sheet for Current Prices.}

\section{Millet}

Used mainly as a catch crop to be used where an early crop has failed. In this section Millet can be somn as late as the middle of July and still make an excellent hay crop. Often sown after Winter Wheat has been harvested.

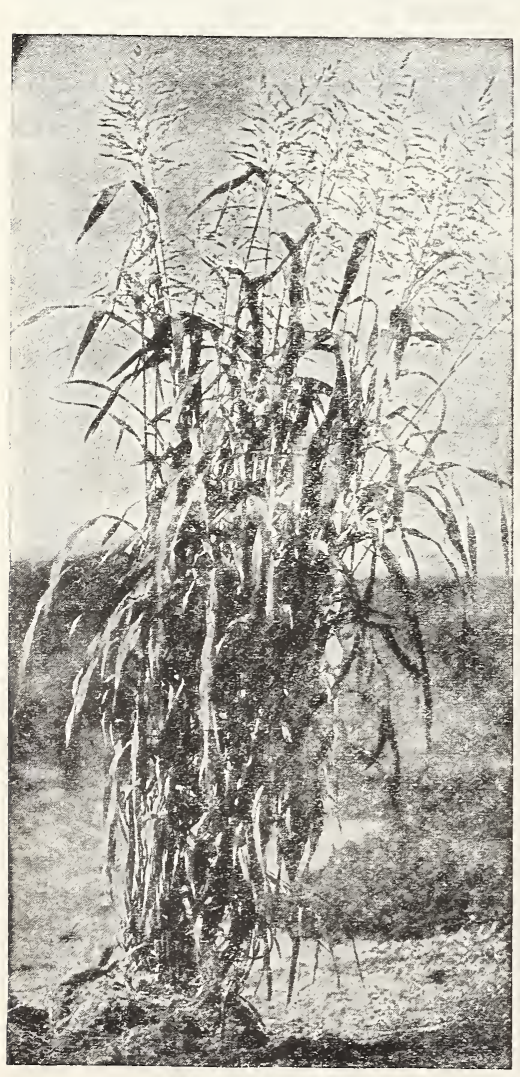

Sudan Grass.

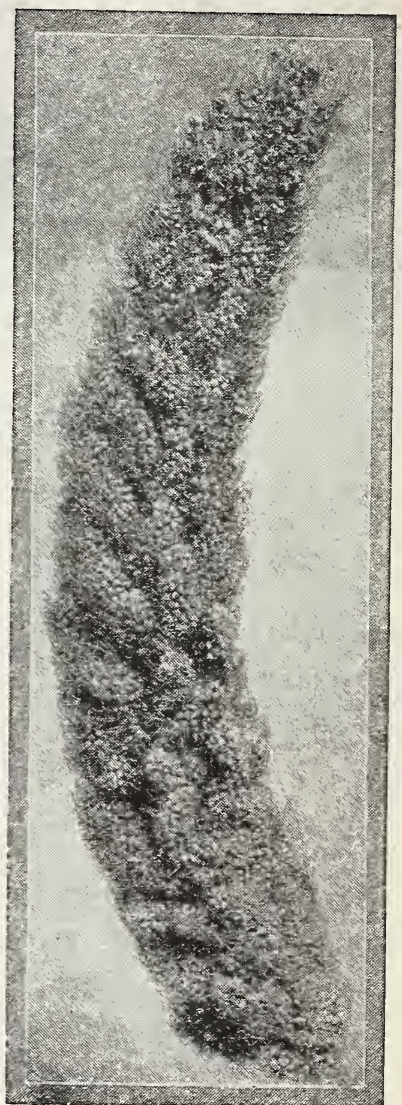

White Wonder Mrillet. While drought-resistant, Millet does
best on moist soil. Because of its rank growth it is extensively used for smothering weeds. The best hay is obtained if cut just as the Millet starts to head; when sown in the spring it gives two good cuttings of hay.

White stonder millet. An early variety with enormous seed heads. The foliage is extra heary and the leaves broad, yielding a very large hay crop. See Colored Price Sheet for Current Prices.

Japanese IMillet or Billion Dollar Grass. Requires only about 6 weeks to produce a crop and can be sown quite late in the season. This crop stools considerably and grows 6 to 8 feet high, producing an enormous crop of hay. Does best on a moist soil. Seed supply is very limited. please give a second choice when ordering.

Golden or German Millet. A good drought resister. Grows very rank and makes a very palatable hay.

Siberian or Russian Millet. Similar to Golden but two weeks earlier Common Millet. One of the earliest varieties.

Hog or Broom Corn Millet. Seed makes excellent feed for poultry and hogs. The seed ripens while the hay is still green, so both can be used. An early variety with a branching head. See Colored Price Sheet for Current Prices.

\section{Sudan Grass}

One of the best catch crops to plant when late seeding is necessary. Matures a crop of hay almost as quickly as Millet and much quicker than the Sorghum crops. Can be cut every six weeks until frost. Frost kills it entirely. A real drought resister, renewing its growth immediately when rain comes. Plants stool freely and make a leafy hay. An enormous hay yielder and the hay can be fed in unlimited quantities without any danger to stock.

\section{Minnesota Amber Sugar Cane}

Used mainly as a catch crop, Minnesota Black Amber is the earliest Sugar Cane It can be grown profitably wherever corn is grown wiil withstand conditions of drought that will ruin corn. It will thrive on your poorest land as well as your best, and is one of the greatest destroyers of noxious weeds.

\section{Buckwheat}

A grain crop often used to smother weeds and clean up weedy soils, Also a catch crop that can be sown late. Good for bees. Japanese. Larger grain crop than Silverhull, and earlier.

Silverhull. Longer season in bloom, best for bees.

\section{Spring Speltz}

A hardy grain that can be grown on poor, arid soils, making a crop under conditions where wheat will fail A very rich feed, and excellent to grind with other grains. Does best when planted very early in the Spring; will withstand cold weather. 


\section{Heavy Mountain Seed Oats}

Plump Mountain Grown Seed filled with vitality. While the Government standard for Oats is 32 pounds to the bushel, our Mountain Grown Seed frequently weighs 45 pounds to the neasured bushel. Oats make a heavy yielding crop for high altitudes.

Colorado side Oats. Exceptionally heavy yielder. Oat See Colored Price Sheet for Current Prices.

Colorado No. 37 oats. A selection made from Swedish Select by Prof. Olin. Early maturity, rust resistant See Colored Erice Sheet for Current Prices.

Victoxy Oats. Short neads, densely branched, bearing lieavy yield of large, plump berries. Originated by 5 wedish Plant Breeding Society.

See Colored Price Sheet for Current Prices.

Abundance Oats. A very large oat and one of the best yielders on good soils. A standard variety, someSee Colored Price Sheet for Current Prices.

Swedish Select Oats. Drought resistant, a good variety see Colored Price Sheet for Current Prices.

New rinlless oats. Very early and a heavy yielder. Threshes practically clean of all hull; solid grain as heavy as wheat. In great demand for rabbit feed by the many rabbit breeders. Also excellent for calves prices.

\section{Plant Winter RYE in Spring for Pasture}

Winter Rye, besides its use as a grain crop, is often seeded in the Spring, either alone or with winter retch as a pasture crop. When sown in the Spring and kept pastured, Winter Rye will last for three or four years with one sowing. Our seed Rye is all Mountain Grown, assuring the strong vitality necessary on this crop.

Rosen 2 zye. The well filled heads and high yield of grain

are the main features of this New Winter Rye. Rosen

Rye was originated by the Michigan Experiment Sta-

tion; our seed was grown from certified seed obtained from the Michigan Agricultural College.

winter Rye. Valuable for pasture or grain crops.

Does well on poor soils or lands that are subject

See Colored Price Sheet for Current Prices.

spring Rye. Not as large straw as Winter Rye but yields a good grain crop of fine quality. Also used for early pasture or hay.

See Colored Price Sheet for Current Prices.

\section{Mountain Grown Seed Wheat}

Marquis wheat. In line with the work being carried on by the Colorado Agricultural College, we im-
ported some second generation Registered Marquis Spring Wheat, grown in Canada, and registered by the Can'adian Seed Growers' Association. This wheat has now been grown here for several years, and while the yield has been greatly increased it still retains the wonderful milling qualities that

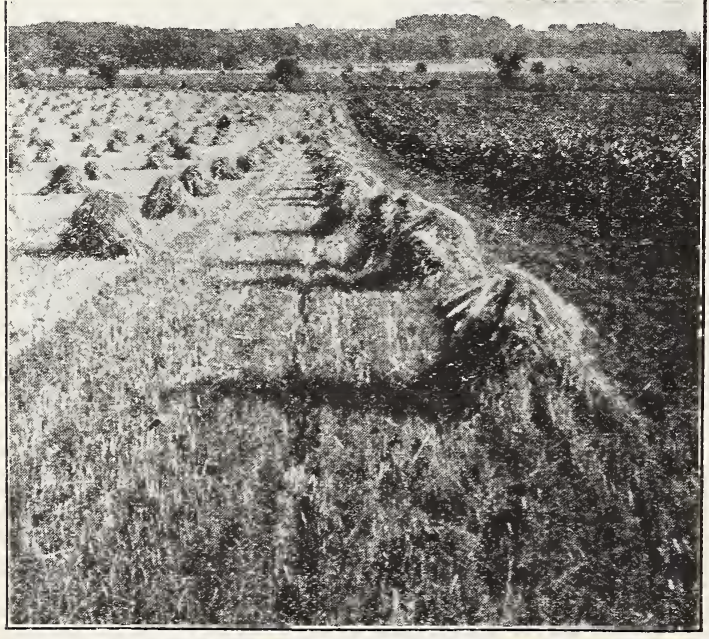

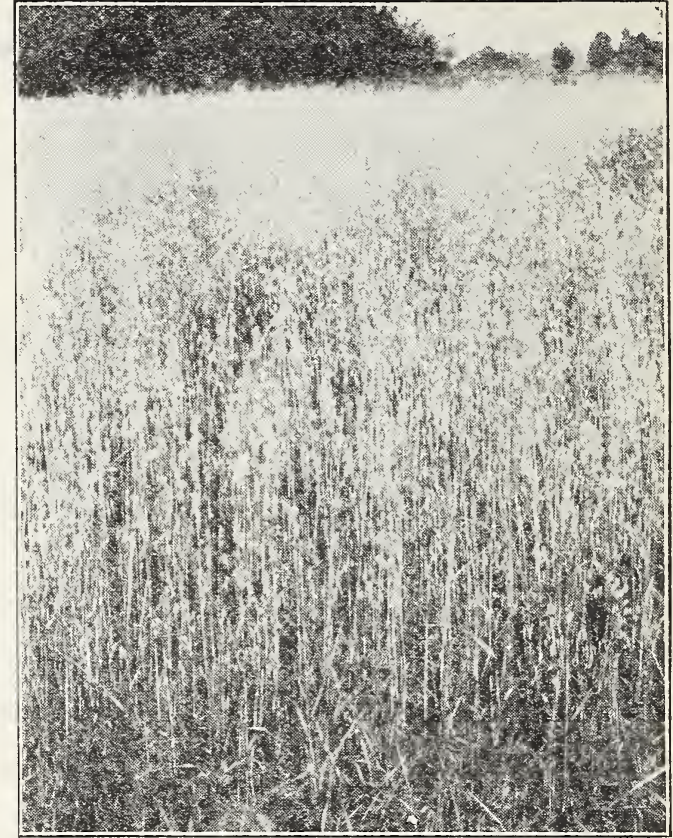

A Clean Crop From Clean Seed.

make this the premium milling wheat of the conSee Colored Price Sheet for Current Prices.

Dicklow Wheat. A new soft wheat yielding over 60 bushels to the acre. Not a milling wheat but the See Colored Price sheet for Current Prices.

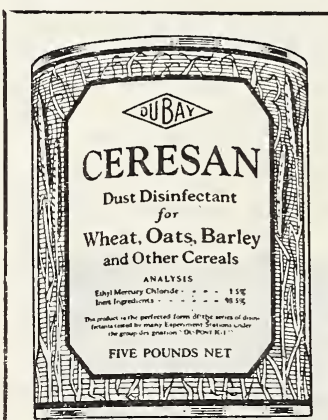

\section{CERESAN}

1. Controls bunt or stinking smut of Wheat.

2. Controls stripe disease of Barley.

Controls loose or covered smut of Barley.

4. Controls loose or covered smut of Oats.

5. Controls covered kernel smut of Sorghum.

\section{FOR SEED TREATMENT} OF GBAINS

Tow only one product is necessary for the seed treatment of wheat, oats, barley, rye or sorghum CERESAN. Here is 'an easily applied dust treatment which has proven effective in controlling such seed-borne diseases as bunt or stinking smut, stripe disease of barley; loose and covered smuts of barley and oats, and covered kernel smut of sorghum.

This is the only dust treatment which has successfully controlled all of these grain diseases, as well as being the first effective dust disinfectant to be offered the farmer for control of barley stripe and smuts. Ceresan does not injure the seed nor the grain drill. Only 2 ozs. of Ceresan required per bushel of wheat, rye or sorghum, and 3 ozs. for barley and oats. Easy to apply, economical to use. PRICES, NOT PREPAID

1 lb. tin ........ 75 25 lb. pail ... $\$ 12.50$ 5 lb. tin $\ldots \ldots .3 .00 \quad 100 \mathrm{lb}$. drum ... 49.00 300 lb. drum ...144.00 


\section{Barley}

One of the earliest grain crops. Barley can be sown late with good results. It makes as good hog feed as corn. Ground Barley is an excellent dairy feed. Our Seed Barley is all high altitude grown, plump, well filled grains. Colsess Barley. A beardless variety developed by the Colorado Agricultural Experiment Station. Gives a heavy yield on a good strong straw. Average yield 74.7 bushels per acre.

See Colored Price sheet for Current Prices.

Improved White Fulless or Bald Barley. It is hulless, be'ardless, very early; it weighs over 60 pounds to measured bushel; it yields well on poor land; it yields enormously on good land. It makes better pork than corn does; the straw makes a good hay; it is of inestimable value to stock feeders.

See Colored Price sheet for Current Prices.

success Bearaless Barley. Hardy, six-rowed and beardless; fine for stock feed.

See Colored Frice Sheet for Current Prices.

Trebi Barley. The heaviest yielding barley that has ever been introduced. Good stiff straw; big, plump grains; an exceptional yielder; replacing sheet for Current Prices.

\section{Field Beans}

The best paying crop of any in many mountain The average yield under irrigation is 1800 pounds per acre, some crops have yielded over 3000 pounds per acre. There has been a good market price on this crop for a number of years, but even at a low price it will bring big returns per acre. We can sell carlot crops for you.

\section{Use this Instantaneous Dip Seed Potato Treatment SEMESAN BEL}

Instead of using chemicals for treating your seed potatoes which require tedious soaking and which sometimes injure the seed piece, use the quick, easy, time-saving semesan belatoes are ready for planting.

\section{Easy, Quick, Effective}

Semesan Bel may be used on either whole or cut" seed pieces, Does not injure sprouts. No hot water necessary. A quick dip into the Semesan Bel solution and the seed potatoes are covered with a protecting film of disinfectant which effectively controls such seed-borne disease organisnis as scab, rhizoctonia and black-leg. By ontrolling these diseases, germination is greatly ncreased, stand improved and the resultant crop of potatoes is bigger and of better quality. Crop increases of from 10 to 15 per cent are common. One pound
treats 16 to 18 bushels of seed.

Prices, Not Prepaid

4 oz. tin .......... $\$ 0.50$

1 lb. tin

5 15. tin

25 lb. pail

100 lb. drum

300 lb. drum

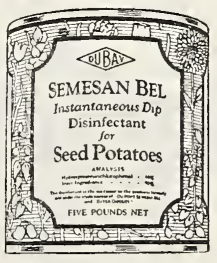

Mexican Pinto. The standard variety in Colorado and New Mexico. Easiest raised, heaviest yielder and seldom any dockage for discolored Beans. Hardy, and the only variety for dry lands. Our true type seed will give a heavy yield.

See Colored Price Sheet for Current Prices.

Great Northern or Iarge White Navy. Matures a crop in 80 days; earlier than Pintos; usually a better price, but not quite as heavy yield.

See Colored Price Sheet for Current Prices.

Small Michigan Pea Navy. A very heavy yielding small white bean, 1200 to 1 type. See Colored Price Sheet for Current Prices.

\section{Field Peas}

San Luis Valley Field Peas can be grown in any altitude up to 9,000 feet with success. This is the Pea that made the San Luis Valley, Colorado, famous. They make exceptionally fine feed for lambs and hogs and the straw is relished by all stock. For a hay crop peas are usually sown with oats, and the crop cut before fully matured. If threshed the dry peas should be ground for cattle, but are usually fed whole to sheep and sows. A field pea crop is a wonderful soil builder, putting nitrogen into the soil for following crops. Our field pea seed is all high altitude grown.

See Colored Frice Sheet for Current Prices.

\section{High Altitude Seed Potatoes}

\section{Dry Land Grown}

Market prices are quoted on our Colored Price lists sent at any time on request. It is well to order early, before some varieties are sold out. We will, of course, make shipment on the date you specify, and when the weather appears favorable. As potatoes are perishable we cannot assume any responsibility for freezing in transit.

The varieties listed below are both early, good yielders, and well suited to the Western territory.

Irish Cobbler. Excellent for light soils. White, and of medium size, roundish in shape. The quality is excellent, especially for baking.

Early Ohio. A week to ten days earlier than the Early Rose, and a better yielder. Pink skin, white flesh, fine grained, excellent keeper. See Colored Price Sheet for Current Prices. 


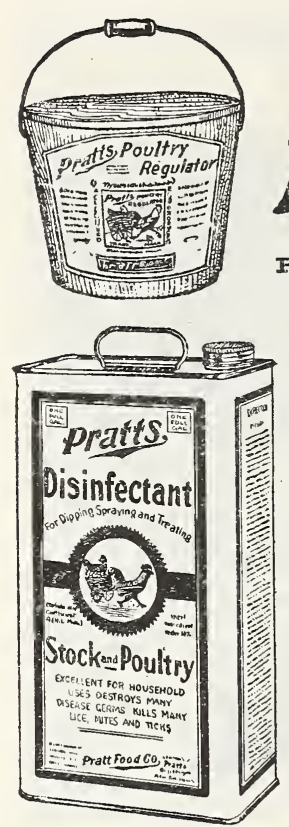

PRATT'S POUTTRY

REGUZATOR makes

any mash better

Medium size package,

shipping weight 5

lbs., not prepaid ... \$0.65

12-1b. package, ship-

ping weight 15 lbs.,

not prepaid . shiping 1.75

weight 102 lbs., not

prepaid .................

TATI'S POUTTRY WORT POWDFR. liedium size package, shipping weight 3 lbs, not prepaid. 60 Large size package, slipping weight 6 los., not prepaid . . 1.20 100-1b. bag, shipping weight 102 lbs., not prepaid ...... 13.50 PRATT'S ANTIVAT REGUTATOR.

Medíum size package, shipping weight 4 lbs., not prepaid. $\quad 7^{70}$ PEATT'S DIP AND DISINEECTANT. Over four times as strong as carbolic acid. For spraying around buildings and dipping stock and poultry.

1 pint, shipping weight $1 \frac{1}{2}$ lbs., not prepaid

1 quart, shipping weight 3 lls., not prepaid.

$\$ 0.45$

quarts, shipping weight 6 liss., not prepaid

SATT'S FED MITE SPECIAI. Spray or paint this special pow-

erful preparation on roosts. 1 quart, not prepaid.

.70

PRATITS FOWTDEED IICE IXITIFR. A powerful and econom-

ical lice killer. Frees poultry, horses, sheep, dogs, cats, etc., from

lice fleas and other vermin.

Medium size package, shipping weight $11 / 2$ lbs., not prepaid

Large size package, shipping weight $3 \frac{1}{2}$ lbs., not prepaid

in each quart $30 \mathrm{c}$; 60c; and $\$ 1.20$, postpaid.

PRATT'S R-P POWDER. Packages, $30 \mathrm{c}$ and $60 \mathrm{c}$, postpaid.

PRATr'S R-P TABIITS. Formerly Pratt's Roup Tablet. postpaid.

PRATT'S TICB SAIVE. Tubes, 30c, postpaid. FRATT'S SPECIAI COMTOUND. Packages, 30c. postpaid.
FRATT'S FIY CFASER.

2 quarts, shipping weight 6 lbs., not prepaid. $\$ 1.00$ 1 gallon, shipping weight 11 lbs not prepaid 1.65 Pratt's Valuabie Poultry Book Sent Free, when Requested With an Order.

\section{"Makomb" Brooders for Baby Chicks}

\section{Standard "Oil-O-Stat" Drum Type "Simplicity" Blue Flame Oil Brooder}
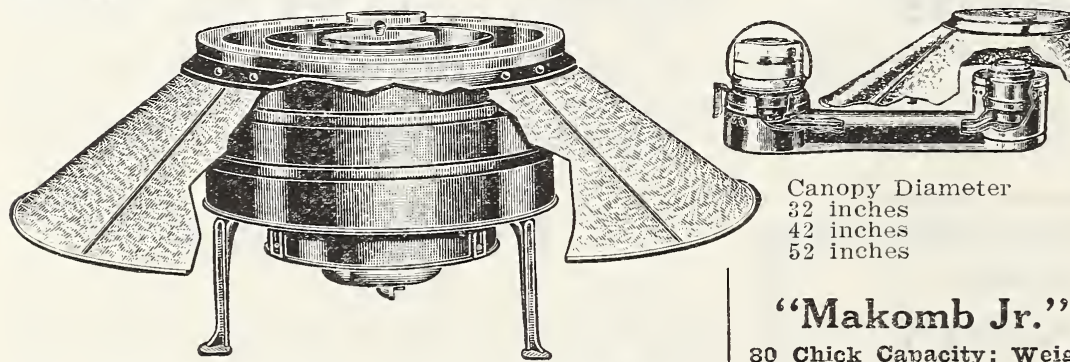

Ieads the world for oil burning brooder value. A olue flame broodtrouble - proof control. Has new pilot light.

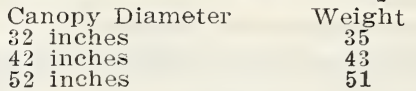

Not Prepaid

\section{"Makomb Jr." Electric Brooder}

Leads all oil brooders in safety and convenience. Burns distillate or kerosene, needs no priming. Can not go out or blow out, ideal in January or June. Will not overheat or underheat, and will care for 100 to 1000 chicks in any weather. Has the wic valve. Does not smoke, will burn as low as one-third to Does not smoke, will without going out. Has everyone-half gallon a day, without going out. Has ever, wire edoed canopy, galvanized pipe cut and fitted for $8 \mathrm{ft}, 10 \mathrm{ft}$. or $12 \mathrm{ft}$. house, with 10 gallon oil tank inside or outside Only attention needed is filling tank with oil.
Canopy Diameter
Weight
Not Prepaid $\$ 27.00$

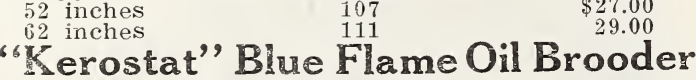

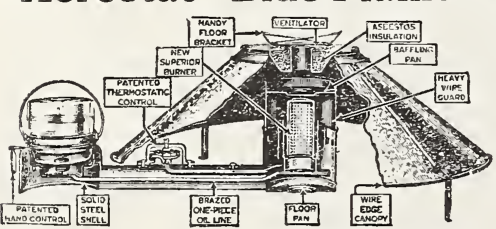

Kerostatirst practical Ther mostatic Blue Flame Oil Brooder with automaic control of the flame. Evfeature is found in the 1930 Kerostat, including new pilot light feature. Only thermostatic control can insure satisfaction. Only Kerostat has it. Blue flame, wickless, odorless, safe and economical, yet low in price 32 in. Standard Weigh

42 in. Insulated

40

Not Prepaid

80 Chick Capacit

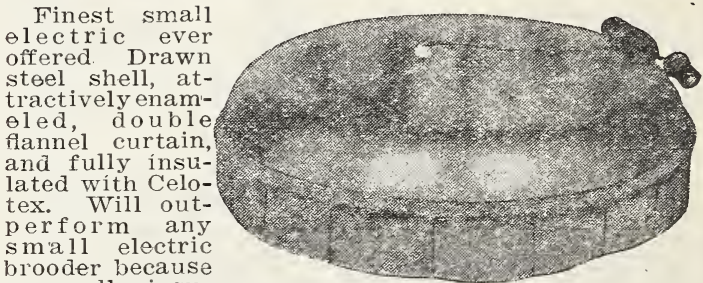
brooder because

lated. Uses 25 or 40 watt bulb, and has circulating drum over bulb which shuts off the light and gives greater efficiency.

\section{Makomb Electric Brooders}

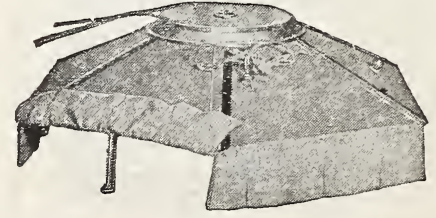

Canopy Diameter

42 inches

52 inches

2 inches
Years of study and the best engineering brain in the quired to perfect this brooder. Completely insulated circular heating system, automatic control, of course.

Not Prepaid

70

86

140 


\section{PROVED BY THIRTY YEARS EXPERIENCE in Calving}

- Sor con Heath

KOW-KARE daily with the feed, two weeks before and two weeks after, works wonders, costs little, and earns big profits in the health and strength of cow and calf and full milk production. Many dairymen feed it for a week every month to prevent disease and insure top-notch milk yield.

BAG BALM, made by KOW-KARE people is wonderful for Caked Bag, Sore Teats, Cuts, etc. Try this healing ointment.

HOW-KARE. Small size, 65c; large size, \$1.25; 6 large cans for \$6.25, prepaid.

BAG BAIII. 60, postpaid.

FOKE ROOT COMPOUND FOR GARGET. $65 c$, postpaid.

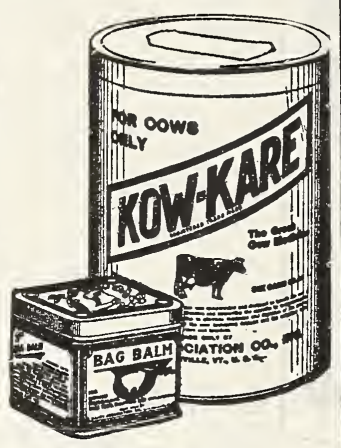

Economy Brand Calf Meal

The excellent quality of our Economy Brand Calf Meal has made it a favorite in the Rocky Mountain section. Those who have used it always keep a supply on hand and repeat orders on this item are the general thing.

Economy Brand Calf Meal carries our full guaranteeyou must be satisfied or your money back.

Can be used for feeding both calves and lambs. Fully equal in feeding value to whole milk. Complete feeding directions enclosed in every sack.

See Colored Price Sheet for Current Prices.

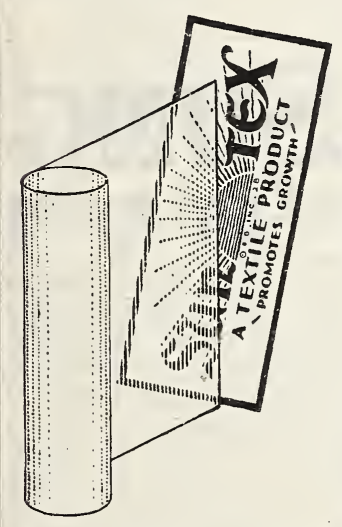

\section{SUN穴TEX}

\section{Better Than Glass}

Makes the Sun work for You

SUN*TEX increases production, because it transmits the Ultra Violet Rays. Used for poultry houses, hotbeds, porches, storm doors and windows.

Weather-Proof and Sun-Proof

Better, earlier plants, that bring the highest market prices.

More eggs, healthier and larger chicks.

Price: 30-inch width, 35c per yard; 36-inch width, 37c per yard, not prepaid.

Roll prices, not prepaid, 30 -in. width. 36 -in width 50 yards $\ldots \ldots \ldots \ldots \ldots \ldots \$ 14.00 \ldots \ldots \ldots \ldots$

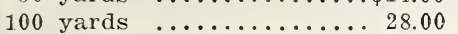
30.00

Shipping weight, $42 \mathrm{lbs}$, per 100 yards.

Small sample of Sun*Tex free on request.

\section{The Little Putnam Stove}

\section{$\$ 1.95$ Postpaid.}

Used under poultry ärinking fountains to keep water at a tonic temperature, also used as the heater element in making an oat sprouter. Stove 4 inches high. Oil tank holds three pints of oil, and burns three to four weeks without refilling or any other attention. Fireproof and non-explosive.

\section{Putnam Brooder Heater}

$\$ 4.75$ Postpaid.

Used to make an inexpensive brooder for 25 to 60 chicks. Full directions for making brooder accompany each Brooder Heater. Consumes less than a gallon of oil per month. Requires filling but once a week and no other attention.

\section{Special Bird Foods}

Postpaid

Special Mired Bird Seed. 1-lb. pkg. .......\$ \$0.20 Magnesia Bird Grit ................. .35 Canary seed. Not mixed. Per lb. ......... .20 Cuttle Fish Bone. Large piece ........... .05 Parrot Seed Mizture. Per lb. .............25 Sunflower Seed. Per lb. ............... .25 Spratt's sing Song. Bird tonic cake ......... .15 Spratt's Cod Iiver Oil Cage Bird and Nestling

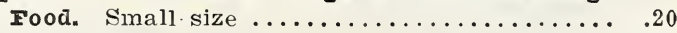

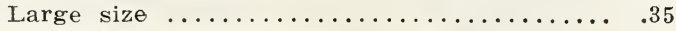
Spratt's Moulting Food ...............

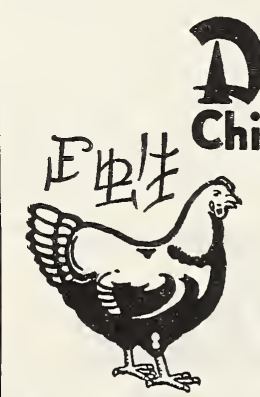

Guaranteed to give more eggsto please you in every way-or we will promptly refund your money.

\section{Trial Offer-No Risk}

Send the coupon with $50 \mathrm{c}$ for the trial size Don Sung. Try Don Sung for a few hens. The Don Sung treatment for one week costs less than one cent per hen.

If you do not believe it has paid you to use Don Sung, write us, and we will refund your money by return mail. You are the sole judge of whether it has paid you on your flock. Send the coupon now with $50 \mathrm{c}$.

Name

Street or R. F. D.

Town State

Fuller information about Don Sung on the next page. 

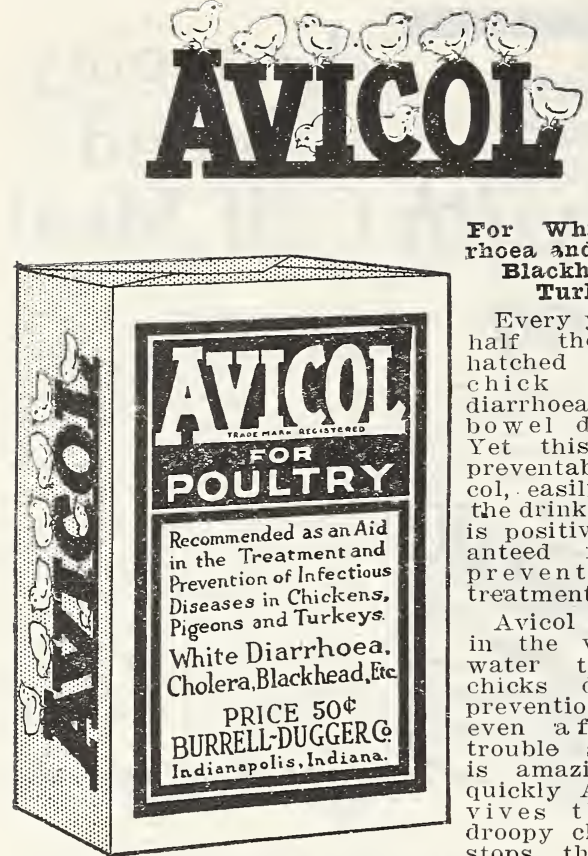

For White Diarrhoea and Cholera; Blackhead in Turkeys.

Every year, over
half the chicks half the chicks chick cholera diarrhoea, or othe Yow el dis eases. preventable. Avicol, easily used in the drinking water, is positively guaranteed for both preventio
treatment.

Avicol should be in the very first water the little chicks drink, as even after the trouble starts, it is amazing ho w quickly Avicol redroopy chicks and

It costs so little that it pays to keep Avicol in the drinking water for the whole flock, all the time. It's wonderful.

"I received the Avicol for White Diarrhoea in baby chicks, and oh, it is a wonderful discovery. I have lost but three chicks since I have been using it, and sending an order for some more. Please hurry it back."-Mrs. G. A. Baugh, Greensboro, Ga

No matter what you have tried, don't judge Avicol Ty anything else Try the genuine original Avicol promptly refunded if you're not more than pleased Avicol is sold in two sizes: Trial size, 50c; large size ( $2 \frac{1 / 2}{2}$ times the $50 \mathrm{c}$ size), $\$ 1.00$; extra large size, $\$ 5.00$, postpaid.

Watch for Roup! Colds and Canker

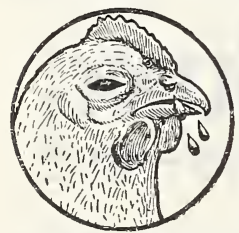
Birds sneeze, wheeze and cholie;

"The Over-Night Roup Remedy"

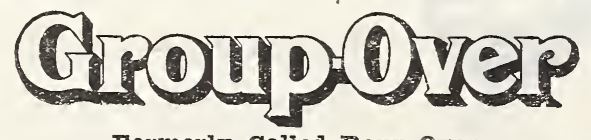

Formerly Calied Foup-Over

GROTP-OVER clears the air passages with magic quickness. Gets rid of the mucous and catarrhal erts an antiseptic, soothing healing action on the Regular Size (bottle)

(The $50 \mathrm{c}$ size is the Trial Guaranteed size)
Inarge size (bottle). Three times $50 \mathrm{c}$ size

WORMOIDS, FOR WORMS IN POUITRY

Most flocks are infested with worms. These parasites sap the health and vitality of the fowl, interfere with laying and stunt development. Symptoms are drooping plumage, general weakness, oftentimes paralysis and death. Wormoids comes in capsule form and is e'asily administered to every birdusually at the same time the flock is culled, banded 50 capsules

150 capsules

$\$ 1.00$, postpaid

500 capsules

5.00 , postpai
U. S. Government Recommends Sodium Fluoride IIIIS AII IICE

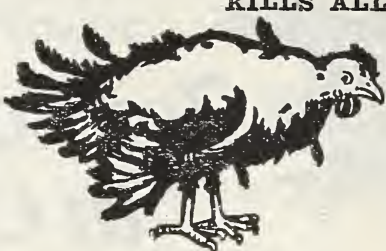

"I Need T. S. F."
The U. S. Government gives in Farmers' Bulletin No. 801: "In this series of found to be as satisfactory as Sodium Fluoride. This chemical is exceedingly poisonous to all species of chicken lice. and young, including the young which emerge from the eggs present at the time of treatment." This Sodium Fluoride method is also now being endorsed by the leading agricultural colleges of the country.

Heretofore, poultry raisers have had trouble in getting this unusual chemical in the proper strength for poultry use. Plain Sodium Fluoride was too irritating. It would cake, harden and lose its strength after being exposed. To meet this situation, there has been developed an improved, less irritating form called "Talcimized Sodium Fluoride." For short, alled "T. S. F."

This $T$. $\mathrm{S}$ is a specially blended and processed mixture of talc and Sodium Fluoride. Being fluffy and finely powdered, it penetrates the plumage more thoroughly than the ordinary Sodium Fluoride-and does the work better and with less irritation. It is packed in moisture-proof, shaker-top packages bearng the U. S. Government's directions for use.

Price: $35 \mathrm{c}$ size (treats 50 fowls); $60 \mathrm{c}$ size (twice $35 \mathrm{c}$ size); Special size, $\$ 2.50$ (five times $60 \mathrm{c}$ size), postpaid.

\section{DONSUNG Chinese for Egg-Laying}

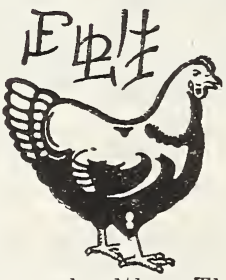

Makes hens healthy-keeps hens eggs are scarce. Guarantees you eggs are scarce. Guarantees you
more eggs or your money refunded. Fron distant China, comes the secret of Don Sung-a mysterious plant extract new to the American hen, but an old, old story in China. To this has been added certain general tonics, conditioners and minerals, designed to keep the whole hen-not merely her egg-laying ous health The result has amazed the poultry raisers of America.

YOU'VE NEVER TRIED ANYTHING IIKE IT

Don Sung is all medicine. There is no needless bulk or filler in it. It acts directly on the egg-laying organs, and is beneficial in every way. It makes hens healthy and happy. They scratch and sing. Pullets develop earlier. The whole flock lays regularly in any season, in any weather, when eggs are scarce and high.

\section{GUARANTEED TO}

you don't get more eggs -if you're not absolutely satisfied that Don Sun has more than paid you, we'll promptly refund money.

Tablet $\mathbf{F}^{\prime}$ orm

$50 \mathrm{c}$ size (this is the Trial guaranteed size).

$\$ 1.00$ size (3 times $50 \mathrm{c}$ $\$ 5.00$ size (6 times $\$ 1.00$ size).

Postpaia.

Powdered Form

3 Ibs. ......... \$ 5.00 10 lbs. ............ 10.00 25 lbs. $\ldots \ldots \ldots \ldots \ldots 20.00$ Postpaid.

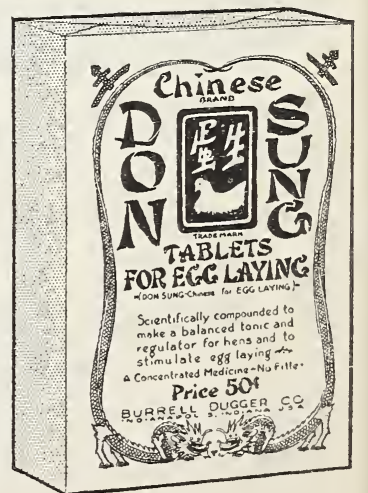




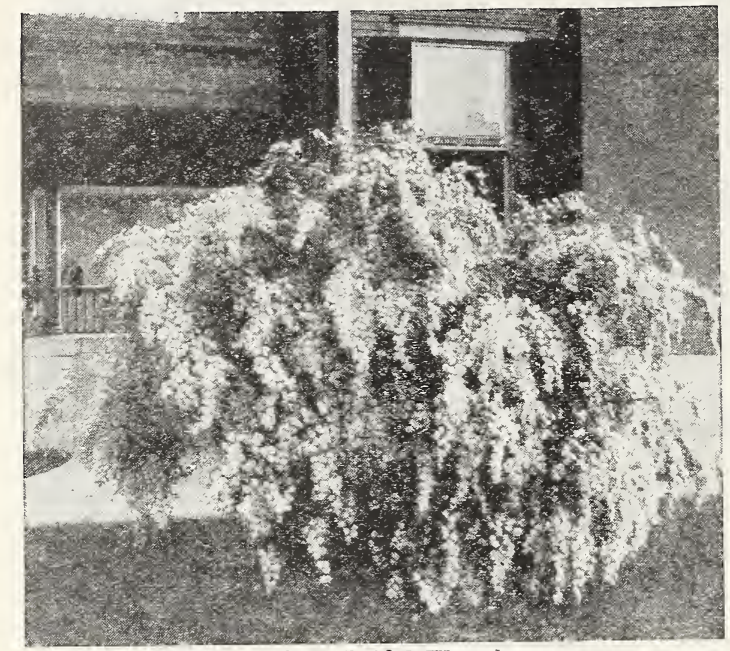

Spirea, Br:dal Wreath.

\section{Ornamental Shrubs}

Charm, grace and beauty are readily added to any home with a few well selected shrubs. A planting around the foundation of the house, a border or group of shrubs at the sides of the lawn, will show the lawn to advantage and make a beautiful home.

Prices not prepaid. If wanted by parcel post, add postage; shipment by express is usually better. Shrubs will be shipped to you from the mountain nursery.

Shipping weight. 1 shrub or rose bush, 2 lbs.; 3 shrubs, 5 lbs.

AIMOND, Pink Flowering. Branches studded with small, double, rose colored flowers. $\$ 1.00$ each.

AIMOND, White slowering. $\$ 1.00$ each.

HYDRAFGEA, Fills of Snow. This is one of the most showy white-blooming shrubs of midsummer. The flowers are like gigantic snowballs and produced in great profusion, forming a most striking display aqainst the delicate green of the foliage. The plant is of dwarf habit, and very suitable for foreground planting, or as individual specimens on the lawn. \$1.00 each.

IILAC, Common Purple. The old, best known variety, with fragrant, purple flowers. 2-3 ft, 65c; each; 3-4 ft, $75 \mathrm{c}$ each.

I.ITAC, Common White. A white-flowered form of the Common Lilac, $2-3$ ft, $60 \mathrm{c}$ each; $3-4 \mathrm{ft}, 75 \mathrm{c}$ each.

IIOCR ORANGE, Sweet. One of the lovely old shrubs, so popular in the dooryards of our grandmothers. Tall growing, producing in profusion in late Spring, clusters of large white flowers having the fragrance of orange blossoms. 3-4 ft, $75 \mathrm{c}$ each.

PRIVIT, Amur. The hardiest of all, and one of the finest for ornamental hedges. It holds its leaves until severely cold weather arrives. When grown untrimmed it is very beautiful, as it blooms freely, producing a profusion of small panicles of white
berries that hang all Winter. 40c each.

SPIREA, Bridal Wreath. This is the most popular of all the Spireas, PIREA, Bridal Wreath. This is the most popular of all the spireas, arching branches, heaped as they are with the white blossoms in Spring, and its thriftiness under the most trying of conditions, are the reason. for its popularity. It is adapted to many purposes in outdoor decoration, and wherever 2-3 ft, $50 \mathrm{c}$ each; $3-4 \mathrm{ft}, 65 \mathrm{c}$ each; $4-5 \mathrm{ft}$. $85 \mathrm{c} \mathrm{each}$.

SPIREA, Froebel. Of the Anthony Waterer type, but more sturdy in habit, Canes distinctly reddish: young foliage tinged red; flowers rose color. Brilliantly colored in Autumn. 2-3 ft, 85c each: 3-4 ft, $\$ 1.00$ each.

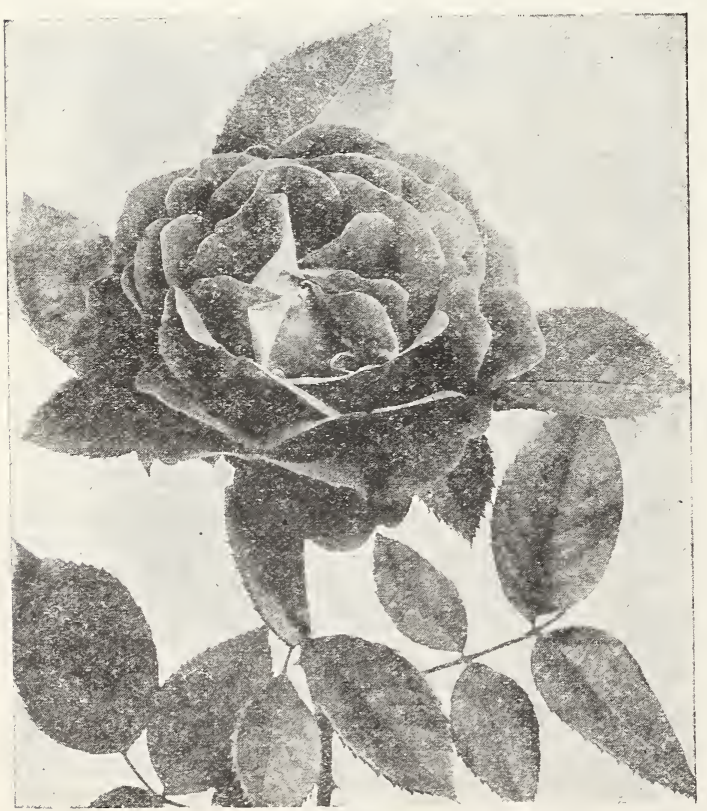

Gruss an Teplitz.

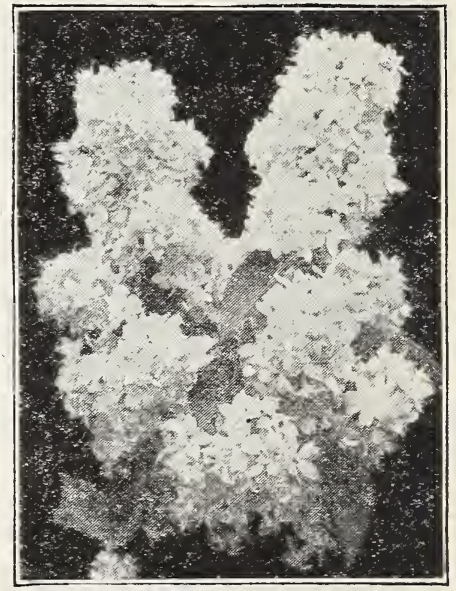

White Lilac.

\section{Roses}

AMERICAN BEAUTY. H. P. Very large blooms of rosy carmine veined with crimson. $75 \mathrm{c}$ each.

CEUSADER. H. T. A very large, very double rose; in color rich, dark, velvety crimson, the blooms coming on long, straight, vigorous stems. $75 \mathrm{c}$ each.

GOIDEN EMEIEM. H. T. Lovely, long buds of golden yellow are beautifully tinted with crimson on the outer petals, offering a delightful contrast. Blooms are produced freely and continuously. 75c each.

GRUSS AN TEPITT. H. T. An old favorite red rose, intensely fragrant. A very large, hardy bush. $60 \mathrm{c}$ each.

x. A. vICTORIA. H. T. Pure ivory white; producing quantities of beautiful buds and full flowers. $75 \mathrm{c}$ each.

RADIANCE. H. T. A lovely light silvery pink with suffusion of a deeper color. Will produce more first class blooms than any other variety. 75c each.

ROSE MARIF. H. T. A perfectly formed flower dark rose-pink, with beautifully reined petals, and a rich, sweet perfume. An exceedingly free bloomer with long stems. $75 c$ each.

PAUI'S SCARIET CLIMIBER. H. W. This wonderful new climbing rose possesses a brilliancy of color unequaled in any other variety. The flowers are an intense, vivid scarlet, semi-double and are rery freely produced in clusters of from 3 to 20 blooms on long, much-branched canes. The petals fall. $75 \mathrm{c}$ each. 


\section{Gladioli-Glory of the Garden}

The Gladiolus is the most popular of all garden bulbs. Costs little and grows and blooms readily in any soil or climate. A most satisfactory garden flower. thriving and

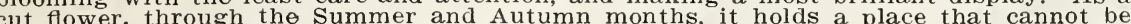
taken by any other flower.

Plant 4 inches apart in rows, or $6 \times 6$ inches apart in masses. In the Fall after the plants have died down, dig the bulbs, allow them to dry in an airy position under cover and then store for the Winter in a cool dry place, away from frost. Albania. Pure snow white, large, wide-open flowers, with beautiful, round petals. 8c each; 75c per doz, postpaid.

Fariy Sunrise. Lignt peach-red shading lighter with spectrum-red blotch on yellow ground. Feathered darker toward edges. $10 \mathrm{c}$ each; $95 \mathrm{c}$ per doz, postpaid.

F. J. Shaylor. Splendid deep rose-pink. One of Kundred's best ruffled varieties; good cut flower. 5c each; 50c per doz, postpaid.

Flizabeth Tabor. Delicate rose-pink with rich crimson blotch; severa flowers open at one time, extremely early. 10c each; 95c per doz, postpaid.

Evelyn Irirtland. One of the best pinks regardless of price; rose-pink with scarlet blotches. $5 \mathrm{c}$ each; $50 \mathrm{c}$ per doz, postpaid.

Halley. Deep salmon-pink. 4c each; $35 \mathrm{c}$ per doz, postpaid.

Fenry Ford. Dark velvety purple. 9c each; 90c per doz, postpaid.

Ie Marechal Foch. Light pinl. 4c each; 35c per doz, postpaid.

rily white. Creamy white, shading to cream in the center; very early. $5 \mathrm{c}$ each; 45c per doz, postpaid.

Mrs. Dr. Norton. Cameo pink, yellow throat; tall vigorous grower; splendid cut flower. 7c each; 65c per doz, postpaid.

Mrs. Francis King. Light scarlet. 4c each; 35c per doz, postpaid.

Mrs. Frank Pendleton. Deep rose-pink, shading to pale pink in throat, large, bright crimson blotches. 5c each; 50c per doz, postpaid.

viagara. Primrose yellow, splashed and striped with bright pink; large flowers on strong spike. $8 \mathrm{c}$ each; $75 \mathrm{c}$ per doz, postpaid.

odin. Light jasper red, shading to a light pink throat; tyrian-rose blotch strong, straight spike. 8c each; 75c per doz, postpaid.

Peace. Large, late white. 4c each; 35 c per doz, postpajd.

Prince of Wales. Delicate salmon-pink, well-shaped flowers on long stems; very early. $6 \mathrm{c}$ each; $60 \mathrm{c}$ per doz, postpaid.

Souvenir. Purest golden yellow, primulinus type. 5c each; 50c per doz, postpaid.

Virginia. A deep scarlet, somewhat deeper in throat. 6c each; 60c per doz, postpaid.

\section{"MIIE IIGI" GIADIOTUS COIIJCIION}

Two each of six named varieties; some varieties listed above on which we have a surplus stock; others, varieties which we have dropped from our list in simplifying the list. You will be more than surprised at the wonderful assortment of gorgeous color and fine blooms we have selected for this collection. Names shown on each variety. Collection of one dozen bulbs for 45c, postpaid.

\section{IIIXED GIADIOII}

Imagine the beauty of a garden made up of all the standard named varieties that we list and some additions made to it from the best types. This is the way our mixture is made up, and we challenge comparison for richness and variety of bloom. 35c per dozen; 30 for $70 \mathrm{c} ; 100$ for $\$ 2.00$, postpaid.

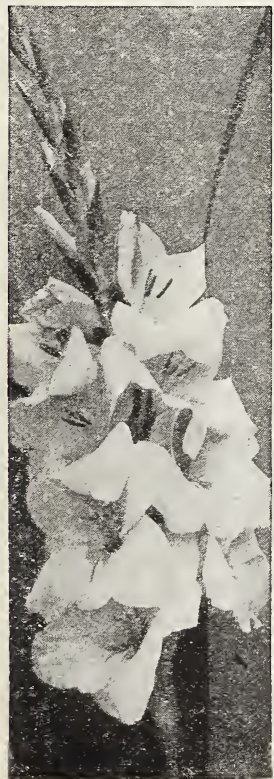

Le Marechal Foch.

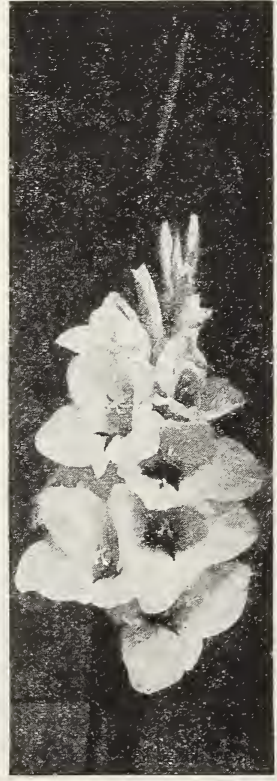

Evelyn Kirtland.

\section{CANNAS}

Cannas are unrivaled for a handsome and showy display. The rich foliage is a pleasant sight all Summer, and the brilliant flowers add a gorgeous touch. King Humbert. Large purplish brown foliage with a metallic tinge, forming a sharp contrast to the orange-scarlet blooms. 20c each; 3 for $40 \mathrm{c} ; \$ 1.25$ per dozen, postpaid.

Yellow King Humbert. In contrast to King Humbert Yellow King Humbert has green foliage and bright yellow flowers beautifully marked with contrasting crimson dots. 20c each; 3 for $45 \mathrm{c} ; \$ 1.50$ per dozen. postpaid.

The President. Rich glowing scarlet; immense flowers, seven inches across when fully open. Heavy green foliage. $20 \mathrm{c}$ each; 3 for $40 \mathrm{c} ; \$ 1.25$ per dozen postpaid.
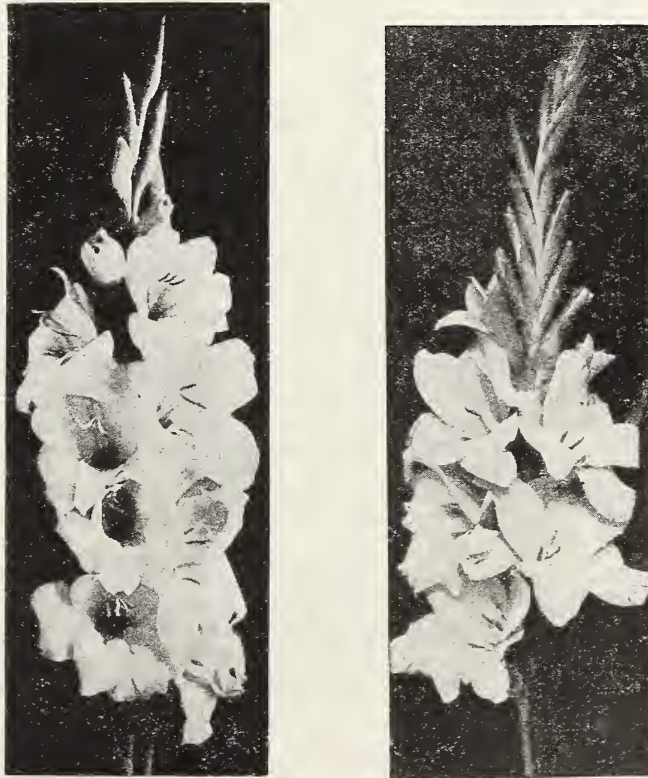

Mrs. Dr. Norton. 


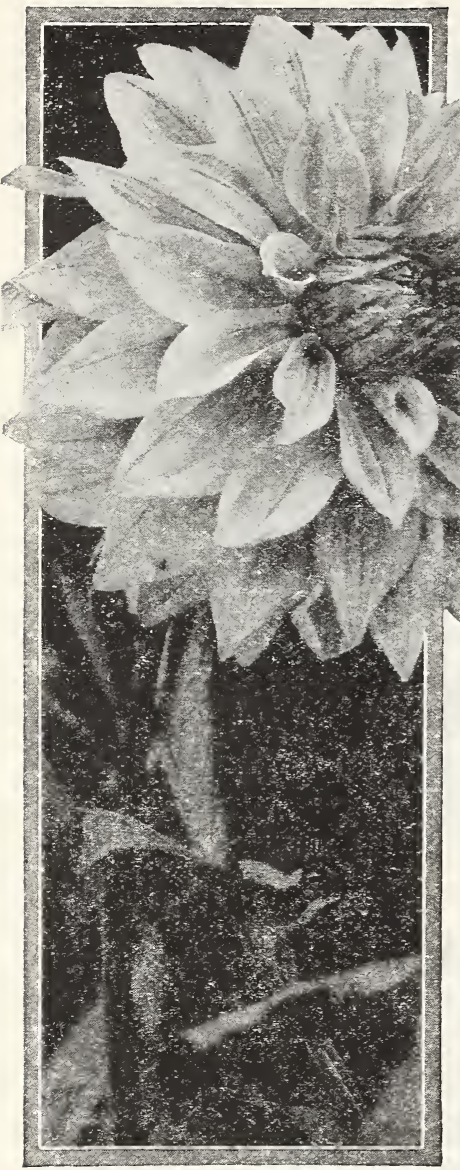

Decorative Dahlia.

\section{ROSAIIE STYIES.}

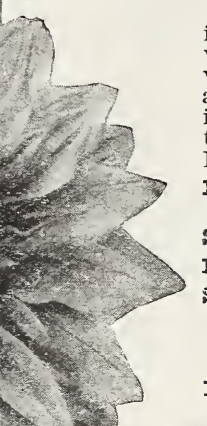
$50 \mathrm{c}$ each; 3 for $\$ 1.40$, postpaid.

DEEIIGHTED. Very large, pure white, combining many good qualities. 25c each; 3 for 70c, postpaid.

GFISRA. (Peony), The showiest and most attractive of this type yet introduced. Petals very long, curved and twisted. A rich combination of scarlet and gold, shaded to amber-yellow. A queen among Dahlias. $\$ 1.00$ each; 3 for $\$ 2.85$, postpaid.

GOIDEN BEDDER. (Dec.). A lovely, clear yellow, very full and perfect in form. Stems long and erect, rendering it an excellent cutting variety. $25 \mathrm{c}$ each; 3 for $70 \mathrm{c}$, postpaid.

GOIDFN WIST. (Cactus). A superb flower of exceptional size, often 7 inches across. Stems long and rigid, holding the flower to full view. Color golden yellow, shaded to pure yellow in center. Has no superior. $50 \mathrm{c}$ each; 3 for $\$ 1.40$, postpaid.

KATE HASIFM. (Show). A small variety but one of the most beautiful in our gardens. Color, a deep pink with light background. 25c each; 3 for $70 \mathrm{c}$, postpaid.

MRS. I DE VER WARMER. (Dec.). One of the finest Dahlias ever introduced A charming deep mauve pink or orchid color. Extra strong grower, producing its gigantic blossoms freely and rigidly erect. 80s each; 3 for $\$ 2.30$, postpaid.

PINK GIOW. (Dec.). Soft pink, with cream blendings, always perfect center. On $\Theta$ of the best, and sure to please. 50c each; 3 for $\$ \mathbf{1 . 4 0}$, postpaid.

PRIDE OF CAIIFORNIA. (Dec.). An extra large, fine flower, borne on long stems. Very large and full, vivid red. Exceptionally fine. 40c each; 3 for $\$ 1.15$, postpaid.

PUPPLE IMANITOU. La Grand Manitou: one of the bes postpaia

Large, deep pink, with yellow center, and with cood stems. Sure to please. 50c each; 3 for $\$ 1.40$, postpaid.

THE GRIZZIX. (Dec.). One of the very best novelties. A great, dark, velvety maroon beauty. Flowers of immense size are held high above the fine foliage on extra long stems. This is a wonderful, prize-winning dahlia. \$1.00 each; 3 for $\$ 2.85$, postpaid.

WrTTE WONDER. (Dec.). Very large white, with just a tint of cream; a splendid flower which at tracts much attention. $50 \mathrm{c}$ each; 3 for $\$ 1.40$, postpaid.

\section{Lost Label Dahlias}

This assortment contains our finest varieties. The labels have been lost from some, others we did not have enough of to list separately. These are the finest varieties, but not named. They will give a
dazzling display. 15c each; $\$ 1.50$ per doz., postpaid. FANCY IEAVED CAIADIUNS

A mixture of the finest varieties combining only the most desirable shades. Very showy foliage plants with red, green and white variegated leaves. A very effective plant, either alone or massed with Cannas severe frost and store bulbs in dry sand. 35c each; 3 for $95 \mathrm{c}$. NEW GOLDEN YEIIOW CAIIA IIIX

An admirable plant with tropical foliage. Very large bright golden yellow flowers. Leaves beautifully spotted with white. Does well in very damp places. For pots or garden culture. $35 \mathrm{c}$ each; 3 for $95 \mathrm{c}$; $\$ 3.50$ per doz.

PANSY RIANTS

ry carefully grown, from our best strains of seed

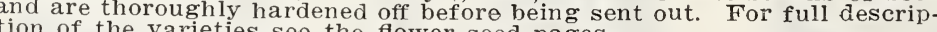
Plants will beties see the flower seed pages.

datents will be ready about March 20th. Orders received before that date will be shipped as soon as ready, unless you specify later shipment. We do not guarantee safe delivery on plants beyond the second postal

PANSX, MIIE HIG SFECIAI. 200 per doz.; 5 doz. for $\$ 4.00$, postpaid. PANSY, OREG ON GI ANTS. $80 \mathrm{c}$ per doz.; 5 doz. for $\$ 3.50$, postpaid.

PANSY, TRIMARDEA. FCe yar doz; 5 doz. for $\$ 3.00$, postpaid.

\section{Pompon Dahlias} Catherine. Lemon-yellow. Deep red.

Any of the above Pompons, 25c each; 5 for $\$ 1.00$ Chinese Cinnamon Vine

The most rapid climber. Perfectly hardy; grows in sun or shade, wet or dry, indoors or out. No in-

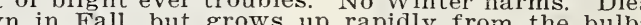
Their abundant blossoms perfume the air for a long distance. No words can describe their delicous fragrance. F'irst size bulbs, 10c each; 3 for $25 \mathrm{c}$; $90 \mathrm{c}$ per doz.

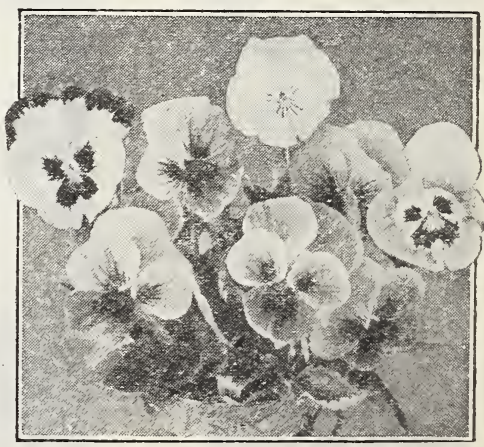

Mile High Special Pansies. 


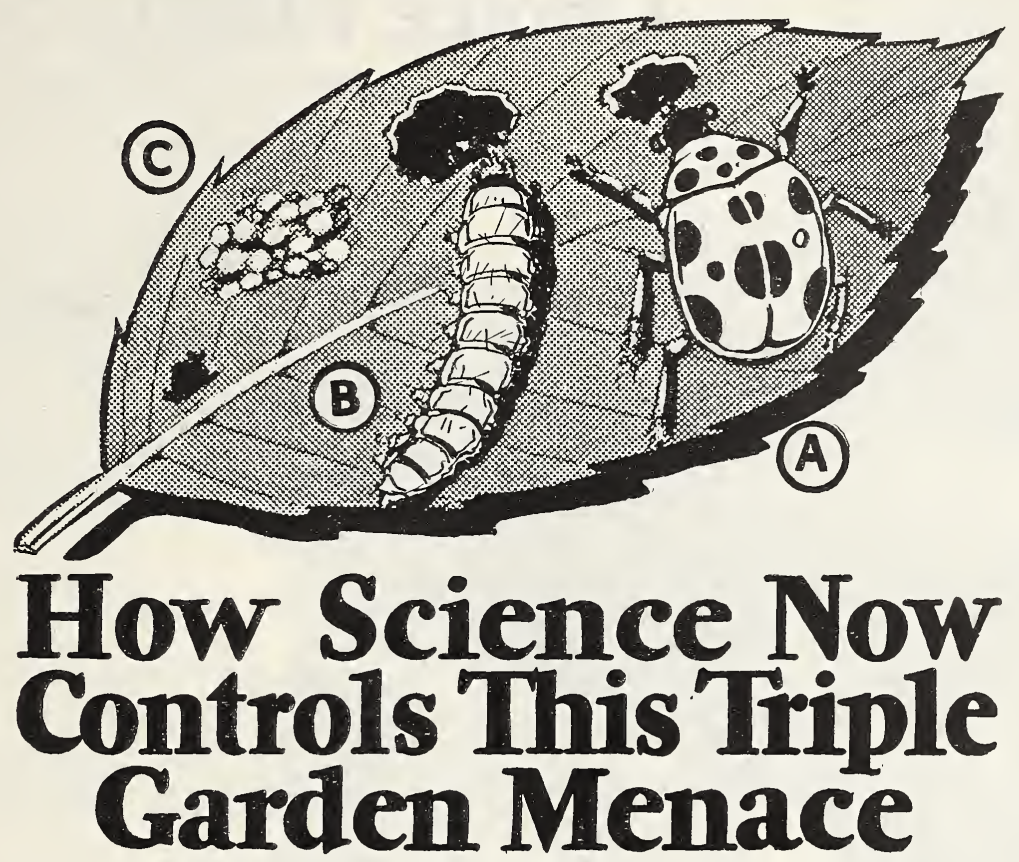

At last! $\dot{A}$ sure SAFE way to rid your garden of destructive insects! End the menace of bugs and worms to your vegetables, flowers and shrubbery! Control "spore diseases" like blight, mildew, black-rot! All without fuss, muss or bother. And most surprising of all, at a cost of only a few cents!

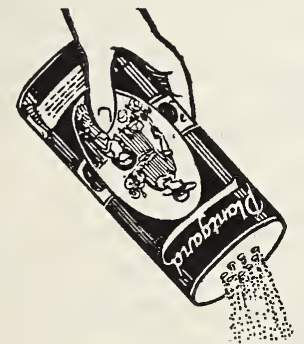

Chewing Insects bite off leaves and stems-when Plantgard is taken into thestomach it kills them, Sucking Insects puncture growing things and

B drink the life juicesPlantgard smothers these insects by closing the pores.

Fungus Diseases are

C caused by vegetable parasites; Plantgard checks and controls them.
THIS new method of controlling all types of plant parasites is called Plantgard. It is a scientific discovery developed after twelve years of research. There is absolutely nothing else like it.

Plantgard comes to you as a fine, light powder. You dust it on the plant like a talcum. Yet in spite of its magical "bug killing" powers, Plantgard is non-poisonous. You can put it on garden vegetables absolutely without danger. Another surprising quality of Plantgard is that it acts as a soil conditioner and fertilizer. Your plants grow faster and better when Plantgard is used freely.

For the benefit of the larger grower who applies the powder with power dusters PLANTGARD is put up in twenty-five, fifty, and one hundred pound sacks at a very attractive price, which will be sent to you upon request.

Try Plantgard today. A big package of Plantgard protection costs only 35c. Larger size, 60c, postpaid. Send for a box at once and see for yourself how quickly this sure harmless method will rid your garden of destructive insects. Order now.

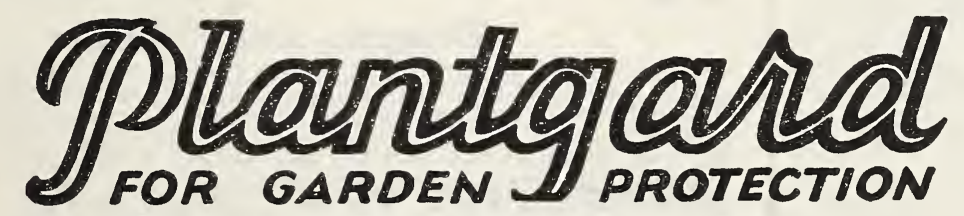

Made only by NATIONAL PRODUCTS, Inc., Quincy, $I l$. 


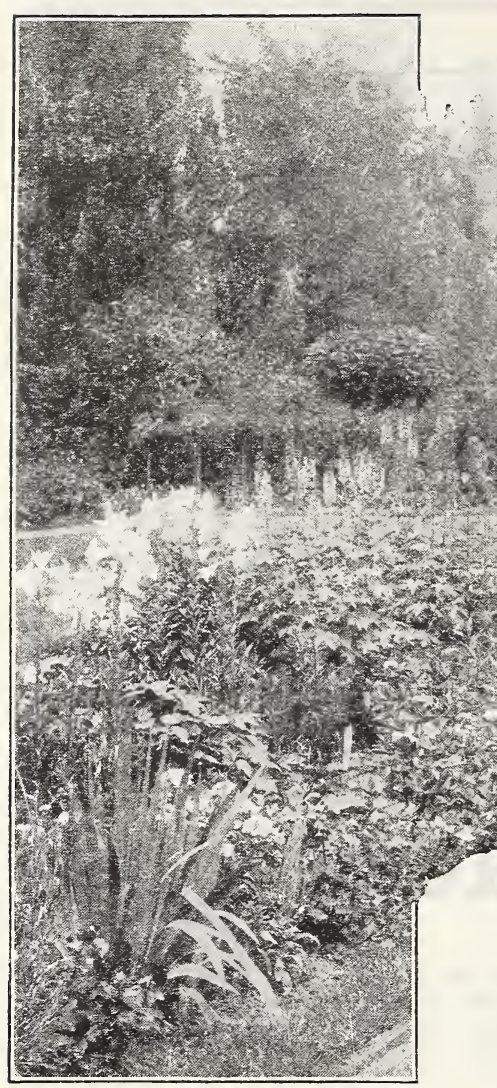

\section{Choice Flower Seeds}

CUITURE FOR FJOWERS

Soils. A good light loam soil, supplemented with a liberal quantity of old well-rotted manure, is the ideal soil for flowers. They require soil which affords good drainage and a free circulation of water. Heavy, sticky soils should have a good quantity of well-rotted manure spaded in to a depth of eight or ten inches. Sand should also be used when obtainable; work this into the soil by spading. Sifted ashes and applications of lime are also good for heavy soils.

General Cultural Directions. Break all clods, remore sticks and trash, have a fine, well prepared seed bed. Flower seeds do not require very deep covering. After placing seed thinly in small furrows fill in with sandy soil, covering seed to a depth of four or five times their diameter. The seed bed should be kept moist -not soggy, with water. A light covering of lawn clippings or long straw will materially assist in germination by preventing a toa rapid evaporation of moisture, and the caking or crusting of soil. Leave the straw or grass covering over seed bed until sprouts appear, and have thoroughly penetrated surface. Seed

that germinates too thickly can be used by transplanting. Cultivate frequently, and give plenty of water for normal growth, applying this preferably late in the afternoon.

\section{Ageratum}

An attractive annual border plant, 18 inches high. Loaded with soft blue and white blooms even in the hot, dry Summer months. Bloom from midsummer until frost. Plst, 10c; 1/8 oz, 20c.

\section{Alyssum}

Low edring plants, literally covered with small white blossoms. Easily grown in any well drained soil, preferably in a sunny location.

894 Sweet Alyssum. Annual trailing plants for porch boxes or borders.

Honey scented white flowers from spring until Fall. Pkt, 5c;

$1 / 2$ oz, 20c; oz, 30c.

Mammoth Flower Collection

\section{$\left.12 \begin{array}{l}\text { Pack et s of } \\ \text { Choice varieties } \\ \text { Postpaid for ... }\end{array}\right\}$}

This collection consists of the finest rarieties of flower seeds. In selecting this assortment we have chosen only varieties which are easily grown and which succeed in a wide variety of soils and under widely different climatic conditions. They will all bloom freely, giving an excellent display. We are packing these collections before the busy season and can make no changes in the assortment. A full size packet of each of the following:

Sweet Alyssum

Beans, Scarlet Runner.

Calendula, Mixed

Castor Oil Plant

Cosmos, Early Mammoth

Flowered

Four O'Clock

Hollyhock, Chater's Double Mixed

Marigold, Dwarf Double

African

Nasturtium, Tall Mixed

Sweet Peas. Special Spencer

Mixed

Sweet Sultan, Giant Centaurea

Zinnia, Dahlia Flowered Mixed
895 Iittle Gem. Compact, quick growing annuals used in borders or as potted plants. Pkt, 5c;1/8 0z, 15c; $1 / 2$. 02, 35c.

896 Basket of Gold. Perennial, producing masses of golden flowers in May and June. Pkt, 10c; 1/16 oz, 20c; $1 / 4$ 0z, $50 \mathrm{c}$.

\section{Amaranthus \\ HAIF HARDY ANWUAT.}

Brilliant foliage, tall border plants. Grow tallest in rich soil, but show finest colors when grown in poorer soils. Plants should be thinned to 2 feet apart.

898 Tricolor, Joseph's Coat. Beautiful variegated leaves of bronze, green, scarlet and gold. Pkt, 5c; 1/8 0z, 15c.

899 Love-Iies-Bleeding. Bears curious drooping racemes of bright red flowers. Pkt, 5c; oz, 30c.

\section{Arabis Alpina}

A charming, dwarf, Spring flowering perennial. Grows 6 inches high; early in the Spring the pure white flowers make a pleasing contrast for Basket of Gold Alyssum. Does well in any soil, but needs plenty of sun. Plkt, 10c; $1 / 4$ oz, 25c; oz, 75c.

\section{Balloon Vine ANNUAI CIIMLBER}

Love-in-a-puff, a clean, free-growing vine reaching a height of 10 to 15 feet. The inconspicuous blooms are followed by attractive balloon shaped seed pods of an inch or more in diameter. Pkt, 5c; 1/2 oz, 15c; oz, 25c.

\section{Balsam - Lady Slipper}

A hardy annual and an old time garden favorite, producing its gorgeous masses of beautiful, brilliant colored, double flowers in the greatest profusion. Balsams do best in hot sun, rich soil and plenty of water. Transplanting two or three times has a tendency to dwarf the plants in to better shape and to make the flowers more double.

957 Camellia Flowered Mired. Pkt, 10c; 1/8 0z, 25c.

955 Double Tall Mixed. Pkt, 5c; 1/4 oz, 15c; oz, 45c.

\section{Scarlet Runner Beans}

Tall climber, large scarlet blossoms, of Sweet Pea form, remain in bloom for a long season. Pkt, $10 \mathrm{c} ; 1 / 2 \mathrm{lb}, 25 \mathrm{c} ; \mathrm{ib}, 40 \mathrm{c}$. 


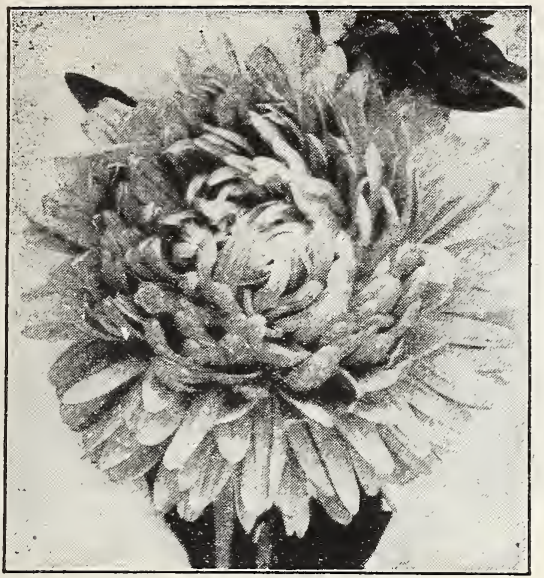

Queen of the Market Aster.

\section{Asters}

HAIF HARDY ANNUAI

During the late Summer and early Fall the garden is usually a riot of reds and yellows, so that the Asters in their dainty and distinct colors are a pleasing addition. The long stems make them desirable for cut flowers and the blooms last long in water.

For early flowers sow the seed in boxes during March or April and transplant to the open ground in May. For late summer blooms sow the seed thinly in the open in May. Good culture is essential to obtain an abundance of the finest blooms.

906 Faxly Beauty. An early-flowering strain of the American Beauty type, a type favored for long, heavy stems and perfectly double blooms. Mixed colors. Pkt, 15c; $1 / 16 \mathrm{oz}, 30 \mathrm{c}$; $1 / 8$ oz, 50c; $1 / 2$ oz, $\$ 1.50$.

922 Extra Farly Express. The earliest blooming of all Asters. Good sized flowers of the Comet type. Mixed colors. Pkt, 15c; $1 / 16 \mathrm{oz}, 30 \mathrm{c} ; 1 / 4 \mathrm{oz}, 90 \mathrm{c}$.

Queen of the Market. One of the

best known of all Asters. Comes into bloom directly after the Extra Early Express and long before other varieties start to blossom. Plants of graceful spreading habit, and double flowers of the American Beauty type.

912 White. Plat, 10c; $1 / 8$ oz, 25c; $1 / 4$ oz, $40 \mathrm{c}$.

913 Rose-Pink. Flrt, $10 \mathrm{c} ; 1 / 8$ oz, $25 \mathrm{c}$; $1 / 4$ oz, $40 \mathrm{c}$

914 Crimson. Pkt, 10c; $1 / 8$ oz, 25c; $1 / 4$ oz. $40 \mathrm{c}$.

917 Purple. Plet, 10c; $1 / 8$ oz, 25c; $1 / 4$ oz, 40c.

918 Mixed colors. Plkt, 5c; $1 / 8$ oz, 20c; $1 / 4$ oz, 35c; oz, $\$ 1.00$.

907 Giant Branching. Beautiful late flowering Asters for cut flowers. The branching habit is accompanied by great vigor of growth and profusion of bloom. Colors are clear and handsome; very large, double flowers; mixed colors. Plt, 10c; 1/8 oz, 25c; 1/2 oz, 65c.

931 The King. Needle type. Flowers large and double, petals quilled, making them entirely distinct from any other variety and a very desirable class. Mixed colors. Plkt, 10c; 1/8 oz, 25c; 0z, \$1.10.

Giant Comet. The Ostrich Feather type of Aster. In habit of growth, the plants are strictly upright with the blooms facing upward. This is a fine class of Asters for bedding as the plants are of even height and compact growth.

928 Crimson. Pkt, 10c; 1/8 oz, 35c.

926 Purple. Plat, $10 \mathrm{c} ; 1 / 8 \mathrm{oz}, 35 \mathrm{c}$.

921 Shell Pink. Fkt, 10c; 1/8 oz, 35c.

927 White. Pikt, 10c; $1 / 8$ oz, 35c.

924 Deep Rose. Pkt, 10c; 1/8 oz, 35c.

920 Special Mixture. Pirt, 5c;1/8 oz, 15c; oz, 60c.

Giants of California A novelty of merit, combining the robust growth and long stem of the Beauty type with the Giant Comet or Ostrich Feather type of flower. The flowers are much larger and more substantial than the Giant Comet. They measure 5 to 6 inches in diameter, stand up well when shipped as cut flowers and have won prizes at exhibitions in all parts of the world.

936 Dark Purple. Pkt, 20c; 1/8 oz, 60c. 939 Peach Blossom. Pkt., 20c; 1/8 oz, 937 Deep Rose. Pkt, 20c; $1 / 8$ oz, 60c.

938 Light Purple. Pkt,20c; 1/8 0z,60c. 941 Mixed. Pkt, 15c; $1 / 16$ oz, 30c; 940 White. Pkt, 20c; $1 / 8$ oz, 60c.
902 Boston Ivy

\section{Browallia}

Browallias are excellent annual's for planting in mixed borders where the long branches can spread out winged flowers in the Summer and Autumn months give a pro-

\section{Calendula - Pot Marigold}

the best and showiest free-flowering hardy annuals. Winter and aluable al

double flower of a brilliant, glistening range $\mathrm{King}$. Outstanding rich , 20c; oz, $\$ 2.00$

Tellow, Massive, well rounded, double blcoms of a rich lemon-yellow shade. Pht, $5 c ; 1 / 2$ oz, $15 c$.

\section{Calliopsis - Tickseed}

Hardy, annual, graceful border plants which will thrive anywhere. 964 Golden Ray. Golden yellow

flowers with dark brown center. Plkt, 10c; $1 / 4$ oz, 25c. 965 Nixed Colors. Pit, 10c; $1 / 4 \mathrm{oz}$ 20c; $0 \mathrm{z}$, 40c.

\section{Canary Bird Vine ANNUAI CIIMBER}

A dainty vine with beautifully cut leaves and pretty, delicate flowers of fantastic shape and clear canary yellow color. One of in the shace. Pist. $10 \mathrm{c} ; 1 / 4 \mathrm{oz}, 20 \mathrm{c}$ $0 z$, 40 c.

\section{Candytuft HARDY ANNUAI}

Valuable bedding plants of fine habit and profuse bloomers. They soon flower from seed and remain long in beauty; valuable cut flowers.

974 Giant White Fyacinth-Flow ered. A grand border plant with large spikes of snowy white flowers. Special select stock. Pkt, 10c; $1 / 40 z, 20 c$.

975 Mixed Colors. Pixt, 5c; $1 / 20 z$, $20 \mathrm{c} ; \mathrm{Oz}, 35 \mathrm{c}$.

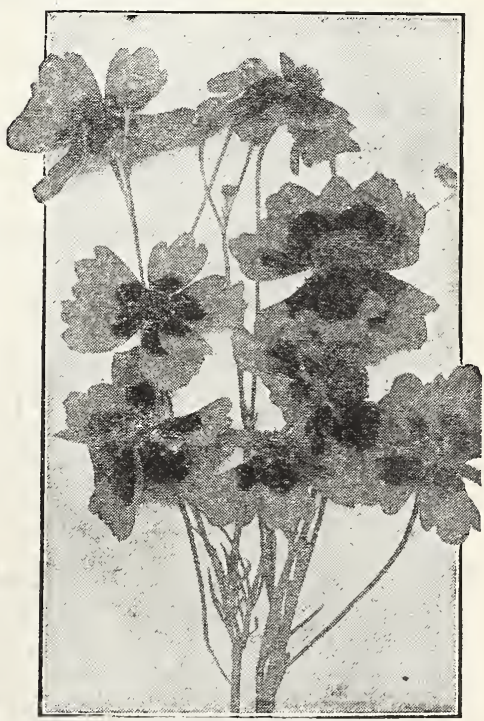

Calliopsis-Tickseed. 


\section{Canna \\ FARDY ANNUAT}

Stately ornamental plants of luxurious growth and tropical appearance. Usually grown from bulbs but can be grown successfully from seed planted early. Soak seed in
warm water 24 hours before sowing. Plkt, 10c; $1 / 4$ oz, 25c.

\section{Canterbury Bells FARDY BIENIIAT}

Easily grown, large, beautiful and important family for the flower garden.

968 single Mixed. White, pink, rose and blue. Pkt, 10c; $1 / 4$ oz, 20c; oz, 50c.

969 Cup and saucer. Fine for cutting, mixed colors. Pkt, 10c; $1 / 16$ oz, $25 \mathrm{c}$; $1 / 4$ oz, $55 \mathrm{c}$.

\section{Cardinal Climber GAIIF HARDY ANNUAI}

A rapid growing vine attaining a height of 25 feet. Fernlike foliage, literally covered with fiery cardinal-red flowers from midsummer until frost. Requires a warm sunny situation. Soak seed in warm water a few hours before sowing.

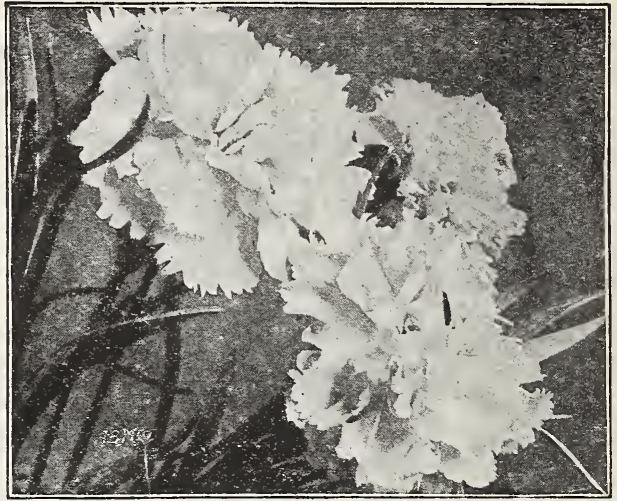

Marguerite Carnations. Pkt, 15c; $1 / 4$ oz, $40 \mathrm{c}$.

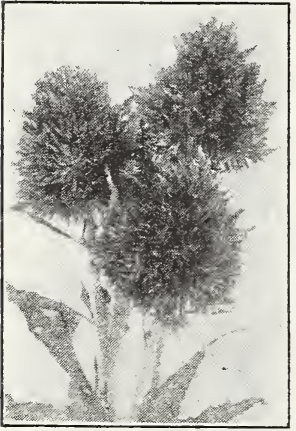

Celosia ChildsiChinese Woolfower.

\section{Marguerite Carnation}

A hardy, free flowering, easily grown variety for flower bed or pot culture. While a biennial the Marguerite Carnation will bloom four months after seed is sown. Plrt, 10c; $1 / 4$ oz, $35 \mathrm{c}$; oz, $\$ 1.10$.

\section{Castor Oil Bean - Ricinus}

Easily grown annual plants of picturesque appearance. Bear immense leaves and the plant is surmounted by large flower spikes, then brilliantly colored seed pods. 985 Zanzibariensis. The tallest variety, growing 10 to $15 \mathrm{feet}$ in height and present

a beautiful tropical appearance. Plrt, 5c; oz, 20c; $1 / 41$ lb, 55c.

984 New Crimson spire. Rich bronzy green foliage and brilliant rosy crimson seed pods. Height 6 feet. Pkt, 10c; oz, 30c; 1/4 1b, 85c.

\section{Celosias - Cockscomb}

The glorious colors of these easily grown annuals have made them very popular. From midsummer until Fall they give a wealth of cut flowers which last nearly two weeks in water. If flowers are cut with long stems and dried quickly in the shade they will last for years like everlastings. Should be grown in a warm, rich soil. 988 Crested Dwarf. Ornamental conb-like heads. Prized for flower bed or pot culture. Plst, $10 \mathrm{c} ; 1 / 16$ oz, $25 \mathrm{c} ; 1 / 8$ oz, $45 \mathrm{c}$.

989 Tall Plumed. Stately plants with massive plumes waving gracefully above the

foliage Pkt, 10c; $1 / 8$ oz, 25c; $1 / 4$ oz, 35c.

987 Chinese woolfiower. Plants two to three feet high, each branch

bearing a ball of scarlet wool. Blooms expand and glow with a deepening richness until killed by frost. Pkt, 10c; 1/16 oz, $25 \mathrm{c}$.

\section{Centaurea.}

992 Bachelor's Button or Cornflower. Very attractive annual growing 2 feet tall and producing flowers profusely from June until frost

Dainty double flowers of the popular blue color. Easily grown in

any garden soil; plant early. Pkt, 10c; $1 / 4$ oz, 20c; oz, $45 \mathrm{c}$.

993 Giant Sweet Sultan. Beautiful, sweet scented, thistle-like flowers on long, strong stems, when cut will last for several days in good condition. Mixed colors. Plt, 5c;1/8 oz, 15c; $1 / 2$ oz, 40c.

994 Giant Sweet Sultan. Pure white. Pkt, 10c; 1/8 oz, 35c.

991 Dusty Miller. Dwarf and neatly compact plants formed by thick,

silvery white leaves. Fine for borders. Bears attractive golden

yellow flower's. Very showy. Pkt, 10c; i/16 oz, 35c.

\section{Annual Chrysanthemum - Painted Daisy}

Easily grown, succeed best in cool growing weather. Their painted flower faces show continuously from June until September. Long stems for cutting and keep well in water.

995 Single IMixed Colors. Flkt, 5c; 1/4 oz., 15c; oz., 40c.

996 Double Mixed Colors. Pkt, 5c; 1/4 oz, 15c; oz, 40c.

\section{Clarkia}

One of the easiest grown hardy annuals, developing to perfection in a cool climate. The plants grow quickly and are in full bloom from 5 to 6 weeks after planting. Contains rosy purple, rose, salmon and white. A fine garden flower and good for cutting. Finest double mixed. Pkt, $5 \mathrm{c} ; 1 / 4 \mathrm{oz}, 15 \mathrm{c}$; oz, $50 \mathrm{c}$.

\section{Coleus}

Highly valued for its brilliantly colored foliage. Coleus may be planted outdoors in well prepared beds or may be grown as pot plants. The plants are easily grown and oan be rept in be grown as pot plants. out the Winter. In a sunny position they will develop their best coloring. If the plants show a tendency to grow too tall the center tips should be pinched out. We offer the large-leaved varieties with rich and brilliant colors, variegations and markings. Choicest mixed. Pkt, 20c; 1/32 oz, 50c.

\section{Cobaea Scandens}

Cathedral Bells or Cup and Saucer Vine. Grows rapidly to a height of 20 to 30 feet. Flowers open a clear green but turn a beautiful purplish lilac. Very vigorous and gives abundant shade. Seed should be sown edgewise and covered lightly. An annual in the North, but perennial in warmer climates. Pkt, 10c; $1 / 8$ oz, 25c.

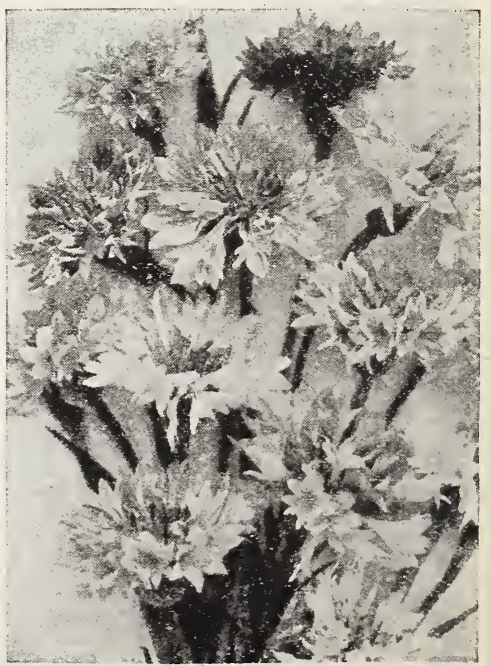

Centauraa-Cornflower. 


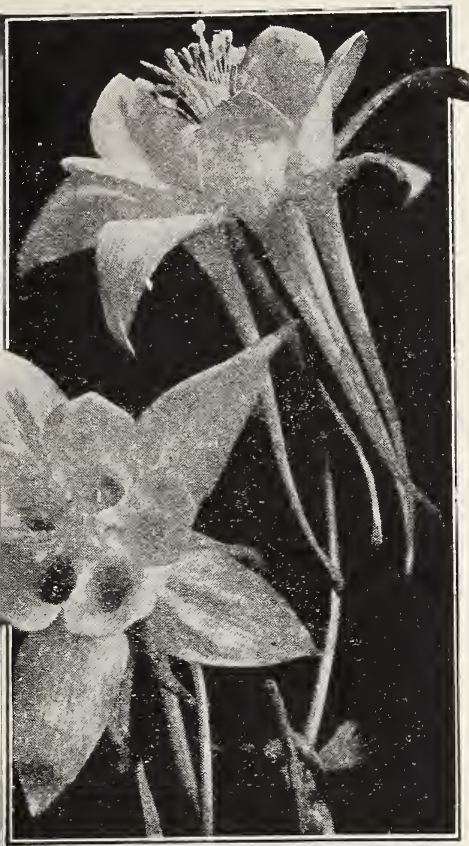

Columbine-Aquilegia.

\section{Coreopsis - Tickseed}

One of the most popular hardy perennial plants, thriving in any rich soil, even in half-shaded locations. Plants grow 2 feet high. The flowers are a most intense golden yellow of graceful frrm and bloom from June to October.

1002 California Sunbeams. Petals are broad and open; fine for cut flowers. Pkt, 10c; 1/8 0z, 20c.

1001 New Flore Plena. Double and semi-double fiowers. Just as easy

to grow as the single and the extra petalage adds a further charm to

the flower. Pkt, 10c; $1 / 8$ oz, 30c.

\section{Columbine - Aquilegia}

The Columbine is one of the most beautiful hardy perennials, producing graceful spurred fiowers on 2 foot stems. They are much prized for cut flowers, making dainty decorations. Columbines are one of the most important of our hardy flowers and should be grown in quantity, being easy to establish and thriving in almost any situation

950 Rocky Mountain, Coerulea. Illustrated in color on back cover. The

state flower of Colorado. Be'autiful native flower with deep blue sepals

and white petals. Easily grown in any garden soil. Pkt, 10c;

$1 / 16 \mathrm{oz}, 35 \mathrm{c} ; 1 / 8 \mathrm{oz}, 50 \mathrm{c}$.

948 Mrs. Scott Flliott's Improved Iong Spurred Hybrids. The blooms are of large size and the spurs very long. The colors range through shades of lavenders, mauves, blues, purples, whites, creams, yellows, pinks, reds, etc. There are no jarring or crude tints, and the whole form a harmonious mass of coloring seldom seen in other flowers. Mixed colors. Plt, 20c; $1 / 16$ oz, 75c.

949 Double Mixed Colors. Pkt, 10c; 1/8 oz, 25c; 1/4 oz, 45c.

\section{Cosmos}

Plants are very bushy and compact, often used as an annual hedge. Flowers of crimson, pink and white resemble single Dahlias on long stems. Finely laciniated foliage. We offer the early flowering strains in both single and double as the later strains are often caught by frost before blooming.

1016 Giant Iate Flowering. Flowers often 4 inches in diameter, plants 6 feet tall. Mixed colors. Plit, $5 \mathrm{c} ; \mathrm{Oz}, 35 \mathrm{c} ; 1 / 4 \mathrm{Ib}, \$ 1.00$.

Iarly Mammoth Flowering. Blooms two weeks earlier than the late flowering. 1005 Crimson. Plst, 10c; $1 / 4$ oz. 25c. 1003 Pink. Pkt, 5c; $1 / 4$ oz, $20 \mathrm{c}$.

1004 Mixed. Plit, 5c; $1 / 4$ oz, 15c; 0z, 35c; 1008 White. Pkt, $10 \mathrm{c} ; 1 / 4$ oz, 25c.

$1 / 4 \mathrm{Ib}, \$ 1.15$.

Double Early Flowering. Fine double flowers of large size, bloom at the same time as the single varieties and last considerably longer as a cut flower. Perfectly formed bushes, 3 feet high, massed with bloom.

1007 White Queen. Pkt, 15c;1/16 oz,50c. 1010 Crimson King. Pkt, 15c; 1/16 oz, 50c. 1009|Pink Beauty. Plrt.15c;1/16 oz,50c. 1006 Mrixed. Pkt, 10c; 1/8 0z, 80c.

1012 klondyke. A gorgeous orange-yellow flower with very handsome foliage, more closely laciniated than others. Prt, 15c; 1/8 oz, 35c.

\section{Cypress. Vine}

For training upon a light ornamental trellis the Cypress Vine cannot be excelled. It has a profusion of scarlet and white star-shaped blossoms, and its finely cut foliage is particularly adapted to ornamental work. Pkt, 5c; $1 / 4$ oz, 15c; oz, 45c.

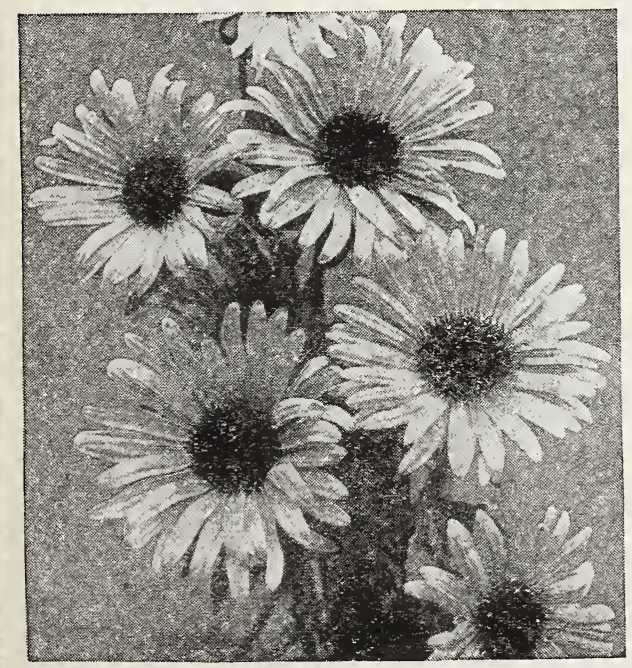

Shasta Daisy, Alaska.

\section{Dahlia Seed}

Dahlias can be easily raised from seed and will bloom the first year. Seed should be started in a shallow box in March or April.

1018 Double Mixed. Pkt, 10c; 1/16 oz, 35c.

1020 Single Mixed. PKt, 10c; 1/8 oz, 30c.

\section{Daisies}

1023 English Double Daisy. Indispensable for cool, shady places. A low growing Spring flowering plant that will reward the gardener with a mass of blossoms for succeeding years if left undisturbed. Pkt, $10 \mathrm{c} ; 1 / 8 \mathbf{~ o z}, 45 \mathrm{c}$; $1 / 4$ oz, $75 \mathrm{c}$.

1022 Shasta Daisy, Alaska. A hardy perennial with immense white flowers borne in the greatest profusion. Easy to grow. They make a fine display even in poor soils, blooming throughout the Summer. Grows 2 to feet tall. Prt. 10c; $1 / 16 \mathrm{oz}, 20 \mathrm{c} ; 1 / 4 \mathrm{oz}, 50 \mathrm{c}$.

909 Arctotis Grandis (African Daisy). Very hardy annual, forms much branched bushes 2 to 3 feet high; its daisylike flowers are pure white on the upper side, the reverse of the petals pale lilac blue. Flowers last 10 days after cutting. Plants will withstand hot, dry weather better than any annuals. Plkt, 10c; $1 / 4$ oz, 25c;0z, 65c.

1021 Golden African Daisy. Beautiful new and extremely showy annual from South Africa. A striking brilliant color in true daisy form. Thrives in a sunny location. Pkt, 10c: $1 / 8$ oz, 30c.

960 Swan River Daisy. An attractive small annual growing about a foot high. The plants form compact little bushes branching close to the ground and bearing small. daisylike flowers on the end of each branch. Plants thrive with plenty of sunshine. Mixed colors of blue, white, rose and violet. Pkt, 10c; $1 / 4$ oz, 40c.

1194 Pyrethrum (Painted Daisy). A hardy perennial, showy plant bearing a profusion of large, daisy-like flowers in lovely shades of pink, red and white. Long stems, excellent for cutting. Blooms during May and June and grows 2 feet tall. Plit, 10c; $1 / 16$ oz, 30c. 


\section{Delphinium}

Few plants are so handsome in the garden as the perennial Larkspurs. The colors vary from the palest lavender to deep indigo. They are perfectly hardy, thrive in any soil, but a deep, rich soil will repay with larger and better flowers.

1027 Elatum Frybridum. Single hybrids growing 3 feet tall. Blooms from

June to August. An excellent strain with beautiful colors. Pkt, 10c; $1 / 8$ oz, 35c.

1028 Belladonna. Flowers an exquisite shade of light turquoise-blue. Blooms in June and July. Height 2 feet. Pkt, 20c; 1/16 oz, 65c.

1029 XXX IFybrids, Mixed. For a number of years our grower has been carefully selecting Delphinium varieties with a view to making a mixture which would contain all the most beautiful shades of color obtainable in a perfect blend. Various formulas were tried out over a period of several years. resulting in these "XXX" Mixed Deiphinium Hybrids. Pint, 20c; $1 / 8$ oz, $70 \mathrm{c}$.

\section{Euphorbia Variegata}

(Snow-on-the-Mountain). A strong growing annual, 2 feet tall. The flowers are inconspicuous, but the plant is distinct and showy, with its foliage edged white and green, 2kt, 10c; 1/4 oz, 25c.

\section{Everlasting Flowers}

Everlastings or Strawftowers not only give a fine effect in beds, borders and as cut flowers, but are also easily dried for Winter use. Cut the flowers early in the morning and hang them, heads down, in a cool, shady and airy place until thoroughly dry. Plants bloom from July until frost.

Helichrysum. Double, everlasting flowers, coming in an assortment of brilliant colors. Plants 20 inches high, do well in all soils, best if planted where they get sunlight all day long.

1044 Fire Ball. Vivid crimson. Pkt, 10c; 1/8 oz, 25c.

1045 Golden Ball. Pkt. 10c; $1 / 8$ oz, $25 \mathrm{c}$.

1046 Rose Queen. . Pkt, 10c; $1 / 8$ oz, 30c.

1047 Silver Ball. Pkt, 10c: $1 / 8$ oz, 25c

1060 Mixed. Pkt, 10c; $1 / 2 \mathrm{cz}, 45 \mathrm{c}$.

$\boldsymbol{\varepsilon} 89$ Acroclinium. White and pink everlastings. Double flowers of silky appearance. A mass of bright blooms. Pkt, 5c; 1/8 oz, 20c.

1.059 Globe Amaranth. Plants 2 feet tall covered with nearly round flowers in a wide range of colors. Pkt, 5c; oz, 35c.

1195 Rhodanthe. Everlastings of graceful habit, growing 1 foot high. A wealth of $1 / 2$ oz, $35 \mathrm{c}$.

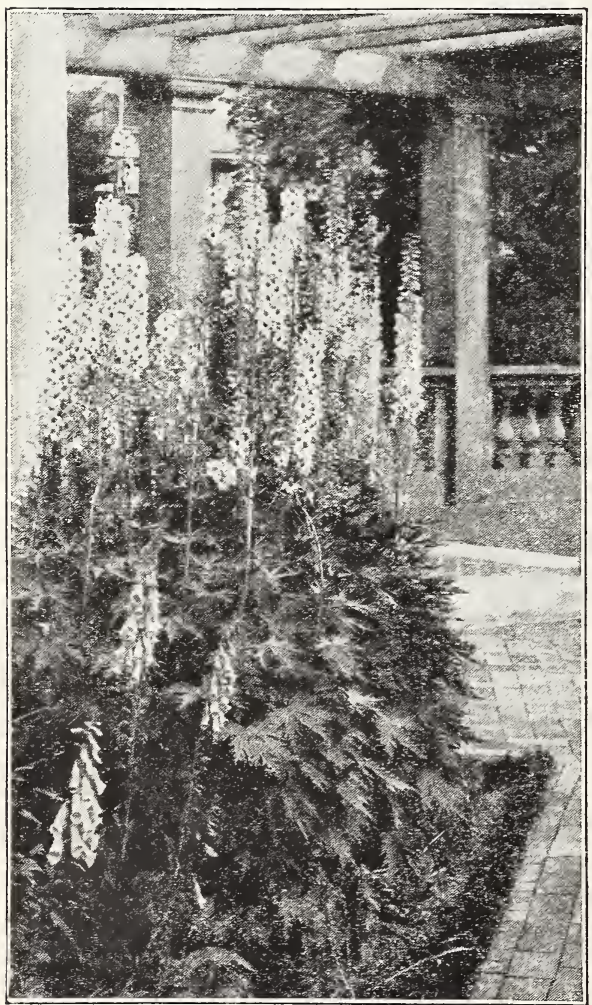

Delphinium-Hardy Larkspur,

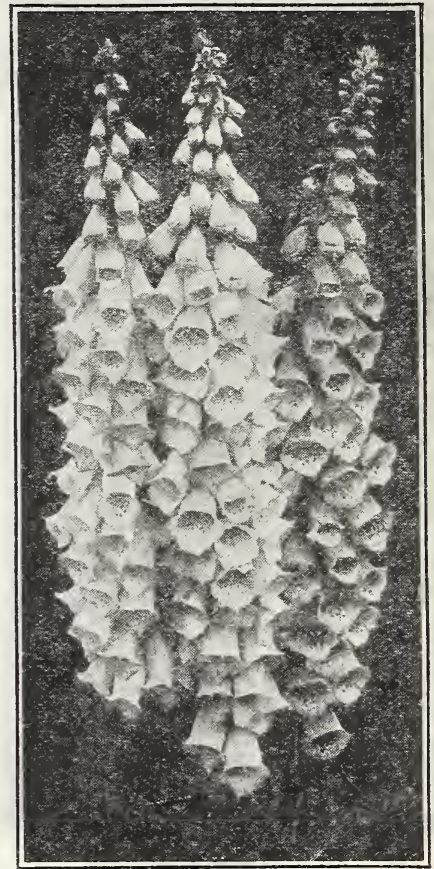

Digitalis-Foxglove,

\section{Forget-Me-Not}

1042 Myosotis Alpestris, Blue. Very attractive, dwarf, freeflowering bushes. Excellent for borders. Light blue flowers standing out sharply from the rich green foliage. They do best in the semi-shade, where the soil does not dry out too quickly. Thin plants to 6 inches apart. They will fiower freely the first season and still more profusely the second Spring. The national flower of Belgium. Plat, 10c; $1 / 4$ oz, 30c; oz, $90 \mathrm{c}$.

1019 Cynoglossum Amabile (Chinese Forget-Me-Not). A lovely plant 18 to 24 inches tall with flowers of a true ForgetMe-Not blue. True blue flowers are scarce so this is a real find for garden lovers. Used as an annual, grows easily an blooms for 'a long season. Plit., 10c; $1 / 4$ oz, 35c; oz, \$1.00.

\section{Foxglove - Digitalis}

Stately, perennial, old garden favorite producing spires of blossoms 3 to 5 feet high. Mixture of white, pink, rose, yel$1 / 8$ oz, $20 \mathrm{c} ; 1 / 20 \mathrm{oz}, 55 \mathrm{c}$.

1089 Climbing Foxglove. A half-hardy annual Mexican climber, and one of our finest trailing annuals. The graceful flowers are of large size and resemble Foxgloves in shape. They are a rich rosy purple color, and bloom from July to frost. Fine for outdoor or indoor culture. Plant outdoors only when nights are quite warm. Pkt, 20c; $1 / 26 \mathrm{oz}, 65 \mathrm{c}$.

\section{Gaillardia}

(Blanket Flower)

They produce from early Spring until late Fall a continuous profusion of brilliantly colored flowers, red and yellow predominating. Easily grown in ordinary garden soil.

1050 Grandiflora, Perennial. Eeautiful, large flowers with yellow tips and crimson centers Excellent for cutting. Pkt, 5c; $1 / 8$ oz, 20c; $1 / 2$ oz, $50 c$. 1051 Single Annual. A most showy wide range of colors. Wonderful in bed or borders or for cut flowers. Pkt, 5c $1 / 8$ oz, 15c; $1 / 2$ oz, 35c.

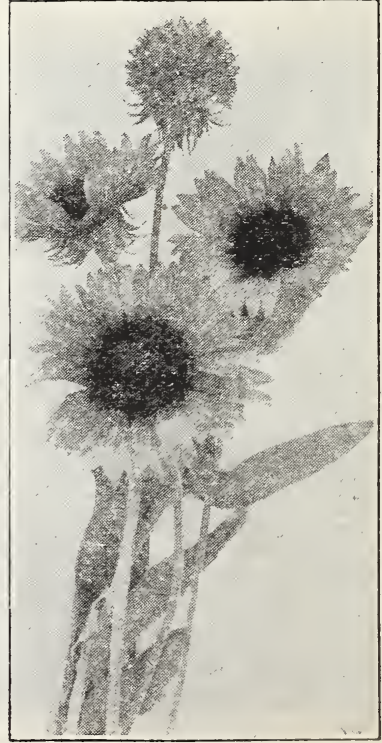

Gaillardia. 


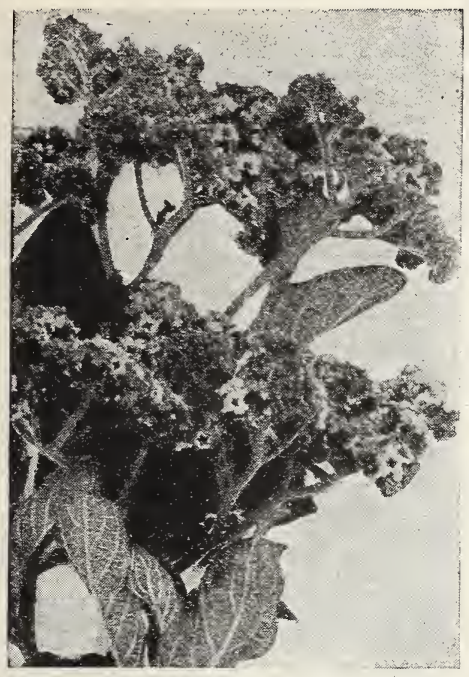

Heliotrope.

\section{Four O'clock}

\section{(Marvel of Peru)}

A most useful annual for beds and borders. Excellent for planting in front of the porch, alongside the house, or makes a beautiful annual hedge. Bears hundreds of sweetscented flowers of white, yellow crimson and violet. Blooms from July until frost. The flowers open about four o'clock in the afternoon. Sow seed early in the Spring. Four O'clock roots may be stored over Winter the same as Dahlias, resulting in larger, stronger plants and more flowers the following year.

1041 Tall Mised. Pkt, 5c; oz, 20c; $1 / 41 \mathrm{~b}, 50 \mathrm{c}$.

1036 Tall Variegated Ireaved Mirsed. Golden hued, variegated foliage. Plat, 10c; oz, 25c; $1 / 4$ 1b, 70c.

\section{Fuchsia} (Lady's Fardxop)

These beautiful pot plants are easily grown and will flower the same year from seed sown early in the Spring. In the South they are hardy enough to live outdoors the whole year. During the hot Summer months they grow Transplant repeatedly and water freely. Pkt, 25c.

\section{Geranium}

1032 Zonale Varieties Mized. Saved from a choice collection, large, single flowers. Pht, $15 \mathrm{c} ; 1 / 16 \mathrm{oz} ; 60 \mathrm{c}$. 1053 Iady Washington. Large flowers, beautifully blotched. Plt, 25c.

\section{Geum}

Geums belong to the Rose family. They are free-flowering and attractive perennial plants for the border or cut flowers. Height 2 feet. Large, double blooms from June to September. To avoid wilting after cutting put stems in warm water.

1054 Mrs. Bradshaw. The orange-scarlet blooms are very large and full; comes quite true from seed and blocms the first year. Pkt, 15c; 1/16 oz, 45c.

1055 Iady Stratheden (Golden Ball). This is a counterpart of the Mrs. Bradshaw, only the blooms are a rich golden yellow. Pkt, 20c; $1 / 16 \mathrm{oz}$, 75c.

\section{Godetia}

1058 Dwarf Single Mixed. An attractive hardy annual flowering profusely all Summer. The showy flowers are of satiny texture and include some lovely shades of rose, carmine, pink, blue, white and other colors. They do best in a rather poor soil and cool location. Plat, $5 \mathrm{c} ; 1 / 8 \mathrm{oz}, 20 \mathrm{c}$.

\section{Baby's Breath}

Gypsophila has myriads Grows 10 to 15 inches tall, does
ation. Fine for planting along walls 056 Covent Garden, Annual. Quick growing annual with beautiful
small white flowers. Blocms freely while the weather remains rea-

\section{Helianthus - Sunflower}

une and July. oc.

showy flowers. Suitable for shrubbery, woodlands, wild gardens and sub-tropical gardening, they are often used as a background or hedge. Many people grow them because they attract birds to the garden.

beautiful single flowers of pure golden yellow with a small brownblack center. Blooms 3 inches in diameter; height 3 to 4 feet. Pkt, 10c; $1 / 4$ oz, 30c.

1216 Double Chrysanthemum-F'low ered. Blooms 6 to 8 inches in diameter resemble giant golden yellow chrysanthemums. Height 7 feet. Plit, 5c; $1 / 4$ oz, 10c; oz, 35c.

1214 Mammoth Russian. Gigantic plants, used for high backgrounds. Useful as shade and feed for the
poultry yard. Plkt, $5 \mathrm{c} ; 1 / 41 \mathrm{~b}, 15 \mathrm{c}$.

\section{Heliotrope}

Heliotrope is a universal favorite on account of its delightful fragrance and duration of bloom, flowering equally well as bedding plants in Summer, or as pot plants in the house during the Winter. Seed sown in the Spring makes fine plants for bedding out, and are as easily grown as Verbenas. Fine mixed, with colors ranging from white through shades of blue and violet. Plrt, 10c; $1 / 8$ oz, 40c.

\section{Hibiscus}

\section{(Giant Mallow Marvels)}

A perfectly hardy perennial plant with canes growing 4 to 6 feet tall. The flowers are of gigantic size and come in various shades of pink, rose and crimson. Blooms all Summer long and makes a stately show. Plrt, 10c: $1 / 8$ oz, $30 \mathrm{c}$.

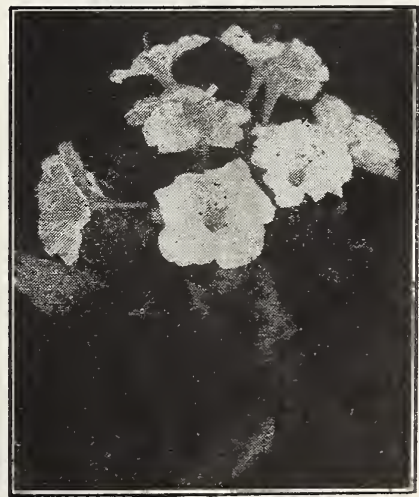

Four O'clocks. 


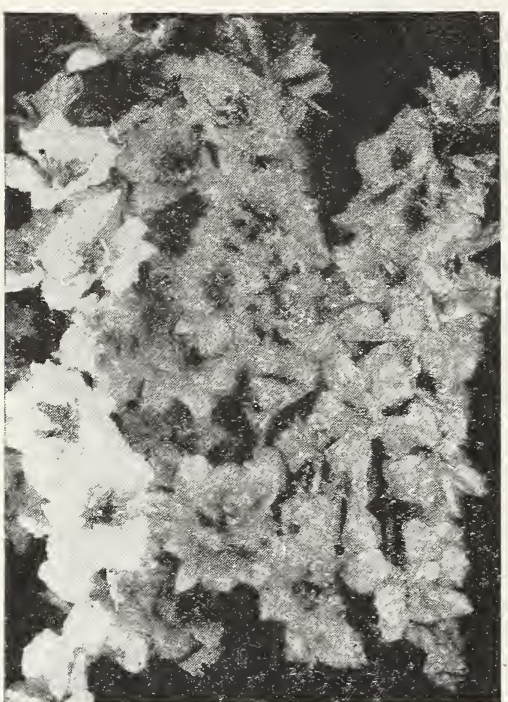

Annual Larkspur-A Fine Cut Flower.

\section{Hollyhocks}

Showy, hardy perennials, plants 6 to 8 feet tall, blooming during Iune and July.

1063 Double, Deep Rose. Pkt, 15c; $1 / 16$ oz, 35c.

1062 Double, Pink. Pkt. 15c; $1 / 16$ oz, 35c.

1065 Double, Yellow. Pkt, 15c: $1 / 16 \mathrm{oz}, 35 \mathrm{c}$.

1066 Double. Mixed. Pkt, 10c; 1/s oz, 30c; 1/2 oz, 80c.

1067 Single, Mixed. Plrt, 5c; 1/8 0z, 20c.

1064 Allegheny Mammoth Mixed. Beautiful pastel shades. Flowers come single, semi-double and double, about 5 inches across, and are beautifully fringed. They are perpetual bloomers, 2 to 4 buds forming at the base of every leaf, where the old-style Hollyhocks have but one or two. These buds open in succession, prolonging the flowering season until Autumn. Plst, 10c; 1/4 0z, 30c; 0z, 90c.

\section{Japanese Hop}

1072 Variegated. Heat, drought and insects do not trouble this rapid climbing vine, which grows to a height of 20 to 30 feet and makes a dense, shady mass in 2 or 3 months. The leaves are variegated. Pkt, 10c; $1 / 4$ oz, 35c; oz, $\$ 1.00 ; 1 / 41 \mathrm{~b}, \$ 3.50$.

\section{Hyacinth Beans - Dolichos}

An annual vine making a strong, sturdy growth and quickly reach. ing a height of 8 to 10 feet. The broad leaves afford good shade and make a fine screen to the porch or garden house plant the seeds after the weather has become quite warm. Blooms in September and October.

1038 Mixed. Flowers and seed pods in white and rose-violet. Pkt, $5 \mathrm{c} ; 0 \mathrm{z}, 20 \mathrm{c} ; 1 / 4 \mathrm{lb}, 50 \mathrm{c}$.

1039 Iignosus (Australian Pea Vine). A rapid growing evergreen climber, flow $\in$ ring freely in clusters of rose, pea-shaped flowers. Plkt, 10c; $1 / 4$ oz. 35c; oz, \$1.00.

\section{Ice Plant - Mesembryanthemum}

The plant received its name from the interesting appearance of the leaves, which look as if covered with a coating of thin ice. Does well in a dry, sunny location. Useful for borders, rock gardens and hanging basliets. Pekt, 5c; $1 / 4$ oz, 20c.

\section{Kochia-Mexican Fire Bush; Summer Cypress}

1075 Childsi. Very quick growing ornamental annual; forms a per-

fectly symmetrical plant, 3 feet tall. Can be grown as a hedge by

planting 2 feet apart. Remains green in the South, but turns a

bright scarlet in the Fall in northern localities. Pkt, 5c; oz, 25c;

$1 / 4 \mathrm{Ib}, 70 \mathrm{c}$.

\section{Kudzu Vine}

Rapid climber. Flourishes where nothing else will grow; a perennial climber which yearly starts new shoots from the crown of the roots, often attaining a height of 40 to 50 feet. Provides a dense screen of large, rich green leaves; the purple flowers are borne in clusters and resemble Wisteria. Pkt, 10c; oz, 65c; 1/4 1b. \$2.00.

\section{Lace Flower}

Lace Flower or Queen Anne's Lace is a most attractive, easily grown annual, with beautiful, delicate, lacelike fiower heads. A much blue flowers. Prt, 10c; $1 / 16 \mathrm{oz}, 30 \mathrm{c}$.

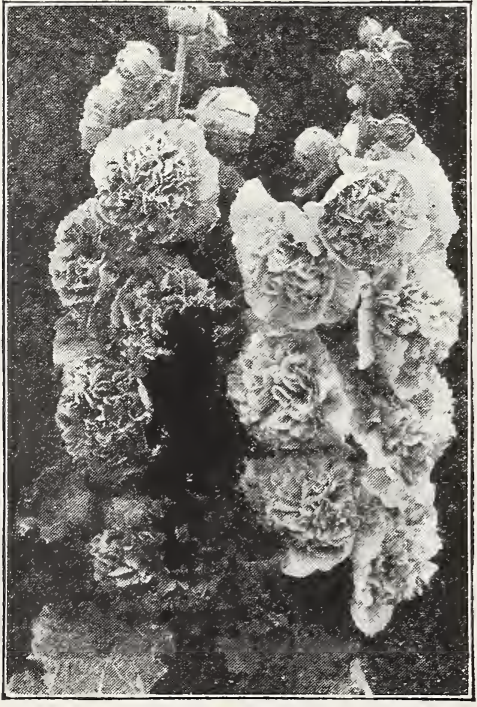

Double Hollyhocks.

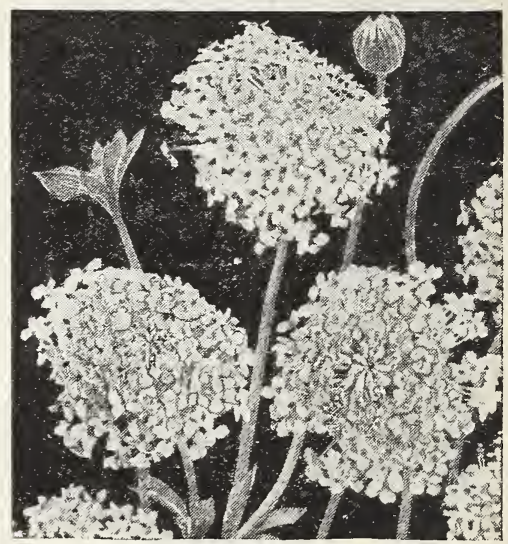

Blue Lace Flower.

\section{Lantana}

1080 Dwarf Hybrids. Shrubby plant with Verbena-like flowers in shades of white, red and yellow. May be grown in pots or set out in Summer, remains in bloom late in Autumn. They have an agreeable aromatic perfume. Pkt, 10c; $1 / 4$ oz, $40 \mathrm{c}$.

\section{Larkspur}

Free flowering annuals with handsome spikes of flowers. Very effective in borders and planted amongst shrubs. The graceful spikes f bloom are much valued for vases. They continue long in bloom. Sow seed in the open in the early Spring. Plants do best in cool and moist ground.

Stock-Flowered. Tall branching plants, 30 inches high, with large, fully double blooms closely set on fine spikes.

1074 Bright Rose. Pikt, 10c; $1 / 2$ oz, $40 \mathrm{c}$.

1077 Dark Blue. Pixt, 10c; $1 / 2$ oz, $40 \mathrm{c}$.

1082 Iustrous Carmine. Pkt, $10 \mathrm{c} ; 1 / 2$ oz, $40 \mathrm{c}$.

1085 Sky Blue. Pkt, 10c; $1 / 2$ oz, $40 \mathrm{c}$.

1085 Sky Blue. Pkt, 10c; 1/2 oz; $40 \mathrm{c}$.

1081 Emperor Mixed. Long, slender spikes in delicate colors. Pkt, 5c; $1 / 4$ oz, 20c; oz, 55c.

\section{Lathyrus - Perennial Peas}

These Everlasting Peas, although lacking fragrance, are very valuable because they last almost indefinitely. Vines grow's to 10 feet tall. Mixed colors of white, pink and red. Plt, 10c; 1/4 oz, 30c; oz, 90c.

\section{Linaria}

1088 Maroccana Hybrida Excelsior Mixed. Free flowering, graceful annual plants, thriving in hot and sunny locations. Fine for borders, window boxes and rockeries. Pkt, 10c; $1 / 4 \mathrm{oz}, 30 \mathrm{c} ; \mathrm{oz}, 90 \mathrm{c}$. 


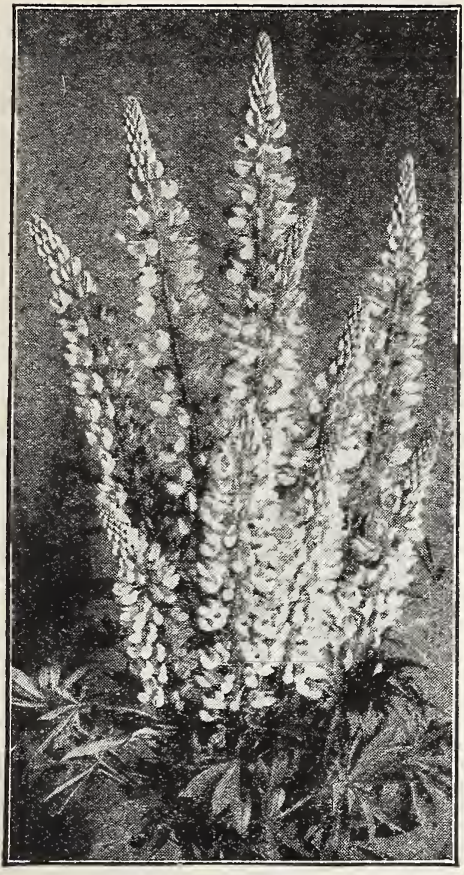

Lupinus.

\section{Linum - Crimson Flax}

One of the most brilliantly colored of dwarf summer annuals, flowers glowing crimson-rose. Very beautiful in beds or borders, and may be had in bloom from May to October by suecessive sowings. Pkt, 5c; $1 / 2$ oz, $20 \mathrm{c}$.

\section{Lobelia}

Annual plants of dwarf growth, covered with small, starlike flowers. Grown extensively for house plants, hanging baskets or as edging for flower beds.

1087 Crystal Palace. Of compact growth, excellent for borders or as pot plants; covered witin deep azure blue flowers. Pkt, 10c;
$1 / 16 \mathrm{oz}, 35 \mathrm{c} ; 1 / 4 \mathrm{oz}, \$ 1.10$.

\section{Lupinus}

Long, stately spikes carried on strong, rounded bushes and a succession of flowers from June to August. Lupinus grows best in soil containing plenty of lime and which is not too moist.

1090 Tall Annual Mixea. Graceful spikes in many colors. Pht, 5c; $1 / 2$ oz, 20c; oz, 35c.

1091 Texas Blue Bonnet. Perennial with long spikes of rich blue flowers, 18 inches high. Blooms twice a year in southern localities. Plst, $10 \mathrm{c} ; 1 / 2 \mathrm{Oz}, 35 \mathrm{c} ; \mathrm{oz}, 55 \mathrm{c}$

\section{Marigold, Hardy Annual}

In late Summer, when many bedding plants are past their prime Marigolds afford a wealth of color that is simply invaluable. The African varieties produce self colored blossoms on tall plants; the French are smaller, but the colors and marlings are very interesting, some of the varieties being elegantly striped and blotched.

1092 Orange Ball, Tall African. Enormous, double flowers of intense rich orange. Flowers are produced in great profusion from July until frost. Fkt, 10c; $1 / 4$ oz, 35c; oz, 95c.

1093 Iemon Ball, Tall African. Extra large, round, double flowers of a clear canary-yellow. Large, round plants with attractive, dark green foliage. F kt, 10c; $1 / 4$ oz, 35c.

1094 Dwarf Double African. Plants 12 to 15 inches high. Mixed colors. Prt, 10c: 1/2 oz, 40c: 0z, 65c

1095 Tall $1 / 2$ oz, 40c: oz, 65c. Pkt, $5 \mathrm{c} ; 1 / 8$ oz, $15 \mathrm{c} ; 1 / 2$ oz, $35 \mathrm{c}$.

1096 Dwarf Double French. Mixed. Prt, 5c; $1 / 8$ oz, 15c; $1 / 20 z, 35 c$.

\section{Matthiola - Evening Scented Stock}

The flowers in the morning, evening and after a shower emit a delicious perfume perceptible at a considerable distance. Dwarf; annual. Fkt, 5c; $1 / \mathbf{4} \mathbf{0 z}, \mathbf{1 5 c}$; $0 z, 35 c$

\section{Moonflower, Annual Climber}

Beautiful vines grow rapidly often to a height of 30 feet. Flowers similar to Morning Glories but open in the evenings and on cloudy days. Foliage large and luxurious.

1104 Bona Noz. Flowers of the softest cerulean blue, often measure 4 inches

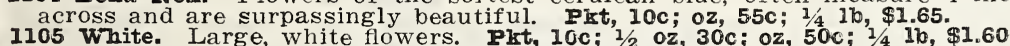

\section{Morning Glories}

their quick growth. They will grow 15 feet tall and bear thousands of flowers of both brilliantly rich and soft delicate shades. Foliage very dense and in some kinds of remarkable shape. Seeds should be soaked in warm water for 24 hours before sowing to assist rapid germination.

1103 Heavenly Blue. Deep, pure sky-blue flowers, delicately shading to white toward the center. Flowers measure 5 inches across; its blue is unequaled, and toward Autumn its vines become more and more floriferous. Firt, 10c; $1 / 8$ oz, 30c; $1 / 2$ oz, 85c.

1108 Selected Imperial Japanese. Colors run from snow-white through all possible shades of blue and red. Flowers are streaked, mottled and bordered

in wonderful fashion. Handsome variegated foliage. Pkt, 10c; oz, 25c; $1 / 41 \mathrm{~b}, 60 \mathrm{c} ; 1 \mathrm{~b}, \$ 1.60$.

1106 Tall. Mixed colors. Fkt, 5c;0z, 15c; 1/4 1b, 40c; 1b, $\$ 1.30$.

1109 Dwarf. Very showy for flower beds or rock work, bloom for a long period and delight in the sun. Pkt, $5 \mathrm{c} ; \mathrm{oz}, 20 \mathrm{c}$.

\section{Nasturtium, Hardy Annual}

For ease of culture and duration of bloom, no flower excels the Nasturtium. They grow vigorously and bloom freely even in the poorest soils. Needing only a well drained soil in a sunny or semi-shaded location, they vouchsafe us a profusion of their gorgeous blossoms. The tall varieties are freest bloomers and produce the largest flowers.

1116 Dwarf. Neat, compact growth, splendid ior boriers. Fine for cut flowers, and the more they are cut the more they bloom. A well balanced mixture with both light and dark foliage and a color range that is magnificent. Pkt, 5c; $0 z, 15 c ; 1 / 41 b, 40 c ; 1 b, \$ 1.20$.

1117 Queen of Tom Thumbs. All the leaves of this type are showily spotted or variegated in contrasting shades of white and green, many of the leaves looking as if powdered with a white frost. Flowers are good size and fine form. A most showy variety. Plt, 5c; oz, 20c; $1 / 41 \mathrm{~b}, 55 \mathrm{c}$.

1120 Tall. Particularly fine for massive beds or broad borders or may be easily made to climb low fences or wire netting. Pkt, 5c; oz, $15 \mathrm{c} ; 1 / 41 \mathrm{~b}, 35 \mathrm{c}$; Ib, $\$ 1.00$

2121 Tall Chameleon. Is unique in bearing flowers of quite distinct coloring on the same plant. Pkt, 5c; oz, 20c; $1 / 41 \mathrm{~b}, 60 \mathrm{c}$.

1122 Iobb's Climbing. Both foliage and fiowers of this fine type are slightly larger than those of the tall Nasturtiums but the wonderful profusion of blooms and intense brilliancy of colors make it particularly desirable. Pkt, $5 \mathrm{c} ; 0 \mathrm{z}, 20 \mathrm{c} ; \mathrm{1} / 4 \mathrm{1b}, 40 \mathrm{c} ; 1 \mathrm{~b}, \$ 1.40$. Flowers rich golden yellow, marked with velvety brown. Best for edging. Plet, 10c; $1 / 4$ oz, $25 \mathrm{c}$; Oz, 55c.

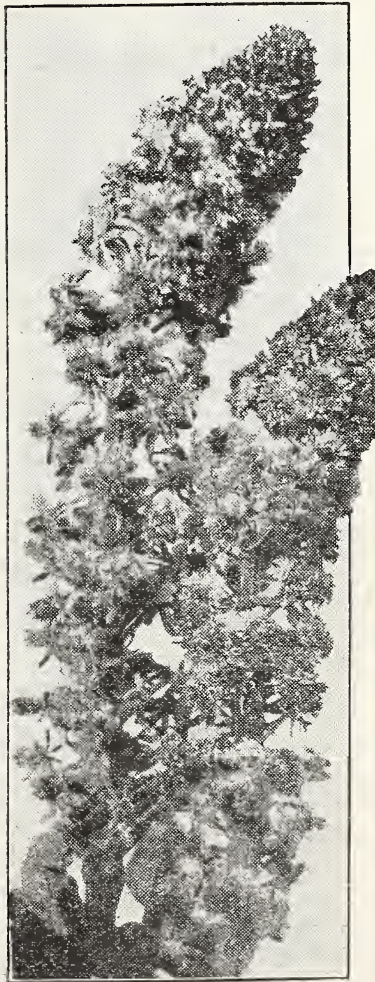

Mignonette. 


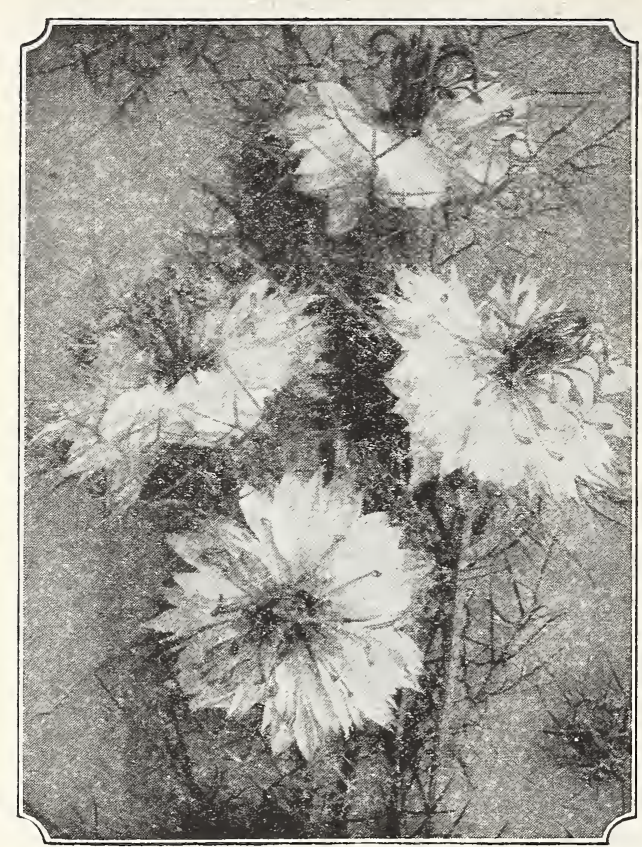

Nigella-Love-in-a-Mist.

\section{Mignonette, Annual}

1101 Dwarf Machet. An extra choice strain, an everbloomer, the flowers lasting until late in the Fall. Pkt, 5c; 1/4 oz, 10c; oz, 25c. 1102 Iarge Flowering. Tall growing variety, excellent for cut flowers; also used as a house plant. Pkt. 5c; $1 / 4$ oz, 10c; oz, 25 c.

\section{Mimulus - Musk Plant}

Lovely little plants with light green foliage, received the name Musk Plant because the leaves have a scent not unlike musk. Bright yellow flowers borne very freely. Excellent for growing in shaded places or for pot culture. Plst, $15 \mathrm{c} ; 1 / 16 \mathrm{oz}$, 60c.

\section{Nemesia}

Free-blooming annual dwarf bushes, 1 foot high, for pot culture and open borders. A sunny location and a moderately rich garden loam with an addition of leaf mold suit them best.

1125 Iarge Flowering Mixed. This is the finest strain of this popular flower, both for size and massive build of the individual flowers, also for the richness and variety of colors. Pkt, 15c; $1 / 16 \mathrm{oz}, 50 \mathrm{c}$.

1124 Dwarf Blue Gem. One of the best blue annuals for edging. Plst, 25c; $1 / 16 \mathrm{oz}, 90 \mathrm{c}$.

\section{6 - Nemophila - Baby Eyes}

A lovely little annual of a beautiful sky-blue color. Extremely hardy and of the easiest culture. The plants are very attractive if planted as a border. Height 6 inches. Plkt, 10c; $1 / 2$ oz, 25c.

\section{Nicotiana}

(Sweet Scented Tobacco Plant)

One of the easiest annuals to raise and one of the most effective. The blossoms in shape are not unlike a Petunia blossom, but with a larger tube. The flowers open toward evening and emit a powerful perfume. Pkt, 10c; $1 / 4 \mathrm{oz}, 25 \mathrm{c}$; oz, 70c.

\section{Nigella - Love-in-a-Mist}

1130 Miss Jekyll. A lovely variety, bearing on long stems large, double flowers of a deep rich blue contrasting well with the feathery light green foliage. One of our prettiest old-fashioned annuals; does well even under adverse weather conditions and withstands considerable heat and drought. Plst, $5 \mathrm{c} ; 1 / 4 \mathrm{oz}, 15 \mathrm{c} ; \mathrm{oz}, 35 \mathrm{c}$.

\section{Oxalis}

plants with clover-like leaves for Thickly starred all Summer with

\section{Pansies}

Pansies, with their little flower faces are an inspiration the gardener. Shakespeare says-"Pansies grown in America and Germany.

A Mastodon. A favorite with florists who must

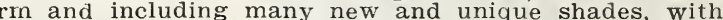
oz, $\$ 7.00$.

44 Tile Figh Special Mixture. An unexcelled mixture potals, standing erect on good, stiff stems with a good, Pkt, 25c; $1 / 16 \mathrm{oz}, \$ 1.10 ; 1 / 4 \mathrm{oz}$,

45 Oregon Giants. The favorite on the Pacific Coast. bronzes, size and contains the richest reds, coppers and anced mixture. Pkt, 25c; $1 / 16$ oz, $\$ 1.00 ; 1 / 4$ oz, $\$ 3.00$ very ext€nsive, the rich, dark and velvety shades pre, solid shades. Pkt, $10 \mathrm{c} ; 1 / 16 \mathrm{oz}, 25 \mathrm{c} ; 1 / 4 \mathrm{oz}, 75 \mathrm{c}$; 3 Standard Varieties Mixed. A good mixture of th
ykt, 10c; $1 / 16$ oz, 25c; 1/4 oz, 60c; oz, $\$ 1.60$.

\section{Pentstemon - Beard Tongue}

, Mixed. Although this is a perennial, the Sensaoors in February or March, they will flower freely the 年 edged with a fine contrasting color. Height 2 feet.

\section{Phlox}

mong the showiest and most easily raised, no other flowtints of the rainbow are represented with all possible variations of stripes, veins and eyes of contrasting shades.

163 Iarge Flowering Choice Annual Mixed. Illustrated in cover. Well rounded, closely formed flower heads, brilliant colors, long stems. Pkt, 10c; $1 / 4$ oz, $40 \mathrm{c} ; \mathrm{oz}, \$ 1.25$.

1164 Star, Annual. Odd and attractive flowers, either starred or fantastically fringed and usually edged with white. Always admired as a cut flower. Pkt, 10c; $1 / 8$ oz, 25c.

1168 Hardy Perennial. New Hybrids. Blooms in late July and August, when there are no other perennials of importance. Easily grown and thrives even under adverse conditions. Pkt, 15c; $1 / 8$ oz, 60c.

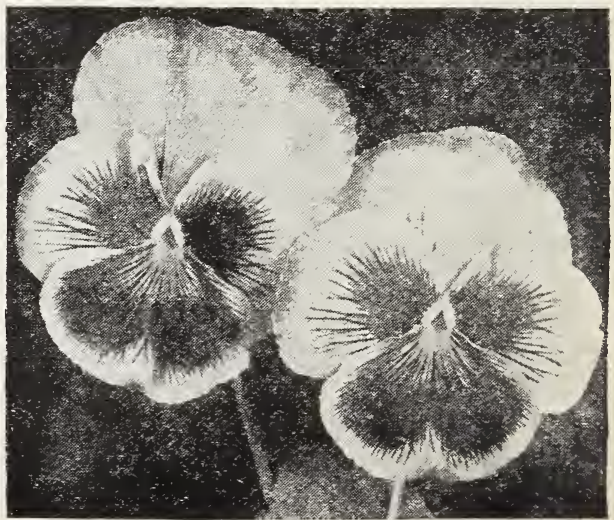

Oregon Giant Pansies. 


\section{Petunias}

For freedom of bloom, variety of color and effectiveness these have no equal. If only a little care is bestowed on them, Petunias will produce their handsome, sweet scented flowers in their delicate and gorgeous colors throughout the summer.

1151 Giants of California. Ruffled. The largest of all Petunias, and the large flowers are particularly attractive on account of the finely fringed and ruffled edges. The color range includes some exquisite lavender and purple shades and also many tones of pink, rose and red. Practically all the flowers variegated or blotched with white. Like all other Giant Petunias the seed should be started indoors in boxes filled with fine soil. Pkt, 35c.

Balcony Petunias. The most valuable type of Petunias, equally useful for planting in porch boxes, beds, terraces or among rock work. The Balcony Petunias may be depended upon to supply an unsurpassed floral effect throughout the

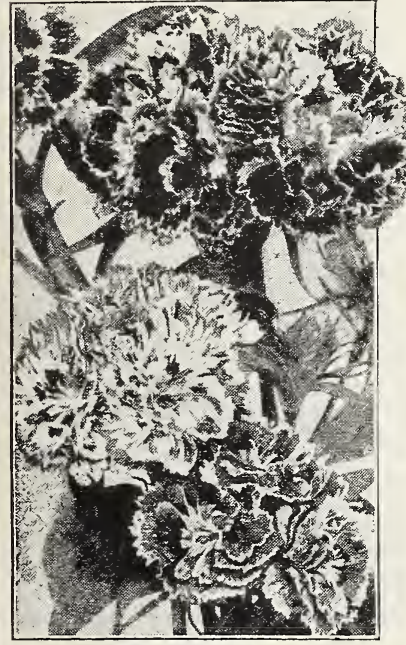

Garden Pinks. Fall. Single, solid

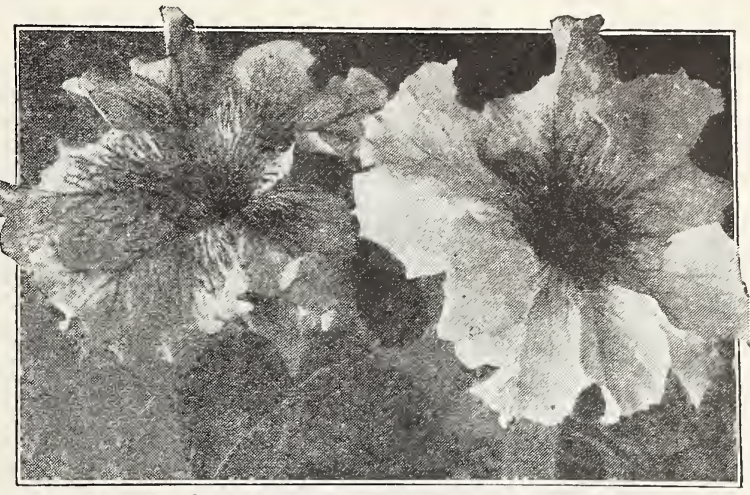

Single Striped and Blotched Petunias. color, large, flow-

ering sorts, the individual blooms measure 3 inches in diameter and they are borne so profusely as to cover the plants throughout the season. 1157 White. Pkt, 15c. 1158 Rose. Plkt, 15c.

1159 Deep Blue. Pkt, 15c.

1160 Mrixed. Plst, 15c; $1 / 16 \mathrm{oz}, 60 \mathrm{c}$. 1149 Flk's Fride. A most outstanding variety with immense flowers of a rich deep Elk's purple. The texture of the petals is substantial and of velvety appearance. The blooms are enormously large and wavy. Elk's Pride is a strong grower and a very profuse bloomer. Pkt, 25c.

1153 Rosy Morn. One of the bedding Petunias. This class is of spreading growth, and much used for beds or in broad and irregular borders. They bloom freely and grow luxuriantly even under adverse conditions. Recommended for window boxes to hang over the edges. Rosy Morn has a silvery white throat, shading to sof $i$ rose-pink toward the edges. Pkt, 1Uc; $1 / 16 \mathrm{cz}, 40 \mathrm{c}$.

1150 Howard's Star. Bedding Petunia. The flowers are attractively marked with a distinct five-pointed, white star on a purplish crimson ground. Plet, 10c; $1 / 8$ oz, 50c.

1154 Blotched and Striped. The plants are of compact growth and well suited for beds and formal borders. The flowers are white, attractively starred and striped with a contrasting rich crimson. Pkt, $5 \mathrm{c} ; 1 / 8$ oz, 25c; $1 / 2$ oz, 65c.

1156 Good Single IVired. Mainly of the bedding type. Pkt, 5c; 1/4 oz, 25c; oz, 75c.

\section{Phacelia}

1167 Campanularia (California Blue Bell). Few blue flowers make such a fine early Summer display as this easily grown annual. Beautiful plants, 8 inches high, producing a terminal raceme of intense gentian-blue, bell-shaped flowers with conspicuous white anthers. Very effective for edgings and a

\section{Physalis}

1169 Francheti (Chinese Lantern Plant). A perennial grown for its showy scarlet-red seed pods which are easily dried for Winter bouquets. The plants are perfectly hardy, $11 / 2$ feet high, and bloom during June and July. The flowers are white. Easily grown in any kind of soil whether sunny or semi-shade. Pirt, 10c; $1 / 4 \mathrm{oz}, 35 \mathrm{c}$.

\section{Pinks - Dianthus}

Few flowers can equal the old-fashioned annual Pinks in beauty and profusion of bloom. They are easily grown in almost any kind of soil. 1031 Double Chinese. Handsome clusters of small, double flowers of all colors, mostly edged with white. Planted in the Spring they bloom profusely during late summer and until cut down by frost. Firt, $5 \mathrm{c} ; 1 / 8 \mathrm{oz}, 15 \mathrm{c} ; 1 / 2 \mathrm{Oz}, 45 \mathrm{c}$.

1032 Double Fringed. Flowers very large and double and the edges of the petals are exquisitely fringed. A mixture of white, pink, rose, red and maroon shades, with white edges and variegated. Pht, 10c; $1 / 4$ oz, 25c; 0z, 80c.

1033 single Fringed. The flowers are beautifully fringed and come in various shades of red with large, white centers and white edges around the petals. Put, 5c; $1 / 4 \mathrm{oz}, 20 \mathrm{c} ;$ oz, 50c.

\section{Poppies}

There are very few gardens that do not show the gorgeous shades and colors of this very easily grown flower. Sow the seed thinly in the Spring, barely cover the small seeds from view. Thin the young plants to allow them room to develop, (the small plants of Ryburgh Hybrids can be transplanted if sown too thickly).

1180 Ryburgh Hybrids. Annual. The flowers are double and resemble a giant carnation, with flat petals overlapping like a double Begonia, The colors embrace all the delicate pastel shades of pink, salmon, orange, etc., all self colors. Pirt, 10c; $1 / 4 \mathrm{oz}, 25 \mathrm{c} ; \mathrm{oz}, 55 \mathrm{c}$.

1173 Carnation-Flowered. Large, double annuals with a wide range of brilliant colors. Fkt, 5c; 0z, 30c; $1 / 4 \mathrm{lb}, 80 \mathrm{c}$.

1174 Peony-Flowexed. Double ball-shaped flowers of gigantic size and wide curly petals resenıbling the Peony in form. Annual. Pirt, 5c; $0 z, 25 c$.

1178 American Iegion. (Shirley). The bright scarlet-red blooms are most brilliant in the full sunshine. Flat, $10 \mathrm{c} ; 1 / 4 \mathrm{Oz}, 25 \mathrm{c} ; 0 \mathrm{z}, 80 \mathrm{c}$. charming pot plant. Easily grown in any soil and can stand dry weather, does well in a sunny location. Plst, 10c; $1 / 4$ 0z, 35c.

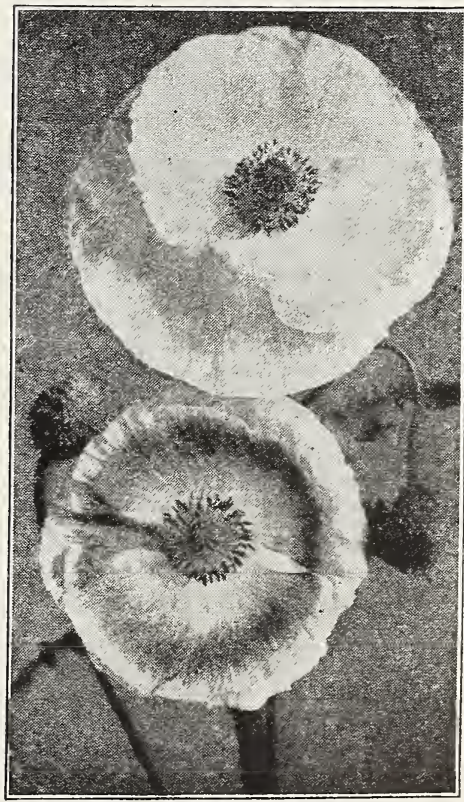

Dainty Shirley Poppies. 


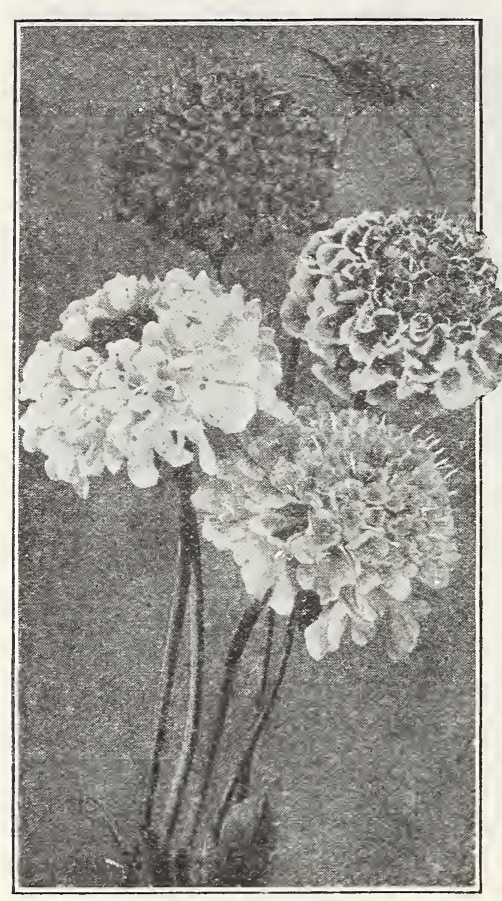

Scabiosa-Mourning Bride. POPPIES-Continued.

1172 Shirley (Silk or Ghost Poppy). Beautiful, satiny flowers of various colors and white centers. Foliage finely cut. Annual. Pkt, 5c; $1 / 2$ oz, 20c; oz, 30c.

1171 Tulip. Large tulip-shaped flowers of dazzling scarlet; similar to a scarlet Duc Van Thol tulip. Annual. Pkt, 10c; $1 / 2$ oz, 40c. 1175 Single Annual. Many of the most dazzling effects are in the simple form and brilliant colors of the Single Poppy. Plkt, 5c : oz, $15 \mathrm{c}$.

1177 Oriental. The most showy of all the perennial Poppies. The gorgeous coloring and immense blooms give a wonderful effect among shrubbery while for cutting they are invaluable. Pkt, 10c; $1 / 8$ oz, 35c; $1 / 2$ oz, $95 \mathrm{c}$.

1176 Iceland. Elegant, free-flowering plants bearing flowers of white, yellow and orange shades in abundance all summer. Perennial. Plkt, 10c; $1 / 4$ oz, $50 \mathrm{c}$.

\section{California Poppies - Eschscholtzia}

The state flower of California. A bright free-flowering plant of low, spreading growth with finely cut foliage. The Poppy-shaped flowers are carried on long stems. Does best in dry, sandy soil.

1181 Carmine King. Beautiful carmine-rose color, both on the interior and exterior of the flower. Pkt, 10c; $1 / 2$ oz, $45 \mathrm{c}$.

1183 Golden west. Bright yellow flowers with a large blotch of deep orange at the base of each petal. Pkt, 5c; $1 / 4$ oz, 15c; oz, $40 \mathrm{c}$.

1185 Mikado. Flowers lustrous orange-crimson. Plt, 10c; 1/2 oz, 45c. 1184 The Geisha. The artistically crinkled petals are golden yellow inside and orange-red outside. Pkt, 10c; $1 / 2$ oz, 60c.

1182 Fybrida. A fine mixture of yellow, orange and crimson flowers. Pkt, 5c; $1 / 4$ oz, 15c; oz, 40c.

\section{Santa Barbara Poppy}

Bush Eschscholtzia or Yellow Tulip Poppy. The plants grow in to a shrubby bush $11 / 2$ feet high and produce their large, cup-shaped flowers, 3 inches across, on stems 12 inches long. The color is a clear bright yellow; the petals are broad and crinkled, like crushed satin. The cut blooms keep in water two weeks. Pkt, 10c; $1 / 4$ oz, 30c.

\section{Mexican or Prickly Poppy}

\section{(Argemone)}

Hardy annual plants with ornamental foliage. The plants grow 3 feet tall. They are of bushy habit and bear a profusion of Poppy-like flowers from July until frost. Mixed colors of white, cream, pink, yellow and gold. Pkt, 10c; $1 / 4$ oz, 35c. hion Plant. Quite hardy annual plants, flowering freely. The age on tall, slender stems nearly feet in length and are of fine, rounded, full-centered form: and tlie blossoms keep well in water. Owing to its sweetness the bees are very fond of it and its floral flavors also attract all the most beautiful types of butterfies to the neighborhood.

1205 Azure Fairy. Flowers par-

ticularly large in a lovely sky-

blue color. Pkt, $10 \mathrm{c} ; 1 / 4 \mathrm{oz}, 25 \mathrm{c}$. 1202 Fiery Scarlet. Pkt, 10c; $1 / 8$ oz, $20 \mathrm{c}$.

1203 Snowball. Plkt, 10c; 1/4 oz, $25 \mathrm{c}$.

1204 Iarge Flowering Double Annual Mrixed. Illustrated on back cover. Pkt, 10c; $1 / 4$ 0z, 20c; oz, $50 \mathrm{c}$.

1199 Perennial Scabiosa. The color is a pleasing light blue. After once being established they will last for many years. Pkt, 10c; $1 / 16 \mathrm{oz}, 40 \mathrm{c}$.

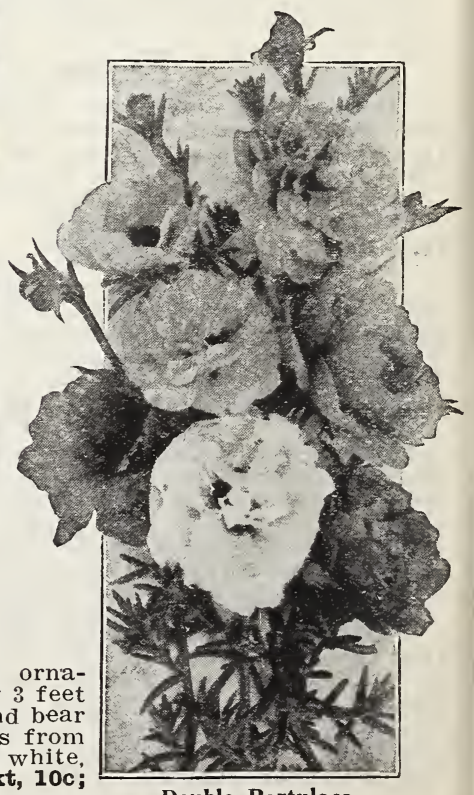

Double Portulaca. 


\section{Salvia - Scarlet Sage}

A stardard annual bedding plant that keeps the garden bright with color until in Autumn. Its best use is as a hedge or border plant, but is also used as a pot plant or for cutting. This large-flowering strain blooms in the Fall with a scorching scarlet of unsurpassed brilliancy. Full grown plants are $\$ 1.10$.

\section{Salpiglossis - Velvet Flower}

of the most attractive annuals and should be in every garden. The blossoms are tube-shaped, much like a Petunia but rivalling the latter in the beautiful colors displayed. Each flower is veined with a glint of gold, and it is the only flower to our knowledge possessing this odd characteristic. The Salpiglossis is deservedly known as the orchid of hardy annuals. Height $21 / 2$ feet.

$1196 \mathrm{Iight}$ Blue and Gold. Fkt, $15 \mathrm{c} ; 1 / 80 \mathrm{z}, 35 \mathrm{c}$.

1107 Scarlet and Golá. Fkt, 15c; $1 / 8 \mathrm{oz}, 35 \mathrm{c}$.

1198 Mixed. Large improved strain, complete range of colors. Pirt, I.Oc; $1 / 8$ oz, 25c; $1 / 2$ oz, $70 \mathrm{c}$.

\section{Smilax}

Decorative piant. Makes a most desirable window vine, the slender stems are covered with small, glossy green leaves. Makes a fine pot or hanging basket plant. Elegant for table decorations when cut. Fkt, 10c; 1/8 oz, 25c.

\section{Snapdragon - Antirrhinum}

Snapdragons are easily orown and make a wonderful display, either in beds or as cut flowers. For gorgeous coloring few flowers can match snapdragons. They are easily grown in ordinary garden soil in a sunny position where the plants can get plenty of fresh air. For early blooming sow indoors and transplant when about 2 inches tall to pots or boxes. If sown right in the open the seed should be covered very thinly.

New Giant rlowered. This new class has become extremeiy popular witlin a very few years. The individual blooms measure fully twice the size of the regular varieties and words fail to adequately describe the glorious colors found in this class. Plants exceptionally hardy and sturdy. 883 Apple Blossom. Rosy pink, white tube. Pkt, 15c; 1/16 oz, $40 \mathrm{c}$.

884 Canary Bird. Canary-yellow. Fkt, $15 \mathrm{c} ; 1 / 16 \mathrm{oz}, 40 \mathrm{c}$.

885 Copper King (Indian Summer). Velvety copper-scarlet. Pixt, 15c; $1 / 16$ oz, 40c.

886 Defiance. Brilliant scarlet. Pkt, 15c; $1 / 16 \mathrm{oz}, 40 \mathrm{c}$.

887 Ruby. Velvety ruby-red. Fkt, 15c; $1 / 16 \mathrm{oz}$, $40 \mathrm{c}$.

888 Snowflake, Pure snow-white, yellow tube. Plt, 15c; $1 / 16$ oz, 40c.

903 Giant Flowered Mixed. Illustrated in color on back cover. All the above $40 \mathrm{c} ; 1 / 8$ oz, $60 \mathrm{c}$.

904 Inarge Tall Mixed. Firt, $5 \mathrm{c}$; $1 / 8 \quad \mathrm{Z}_{\mathrm{s}}$ $20 \mathrm{c} ; 1 / 2 \mathrm{Oz}, 60 \mathrm{c}$.

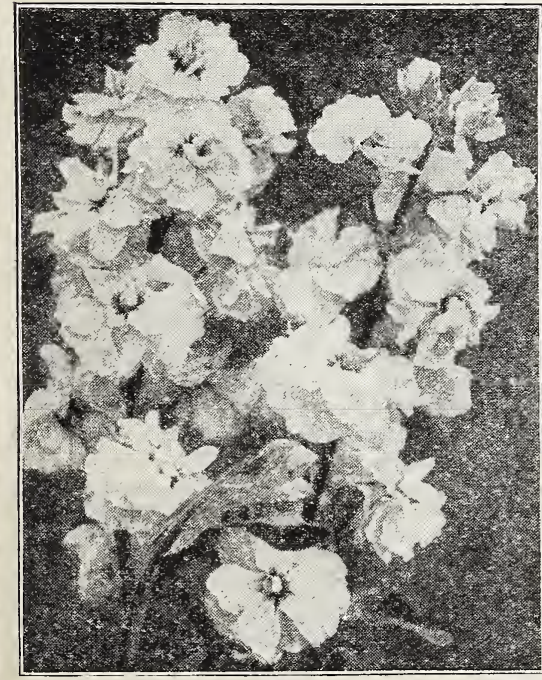

Stocks.

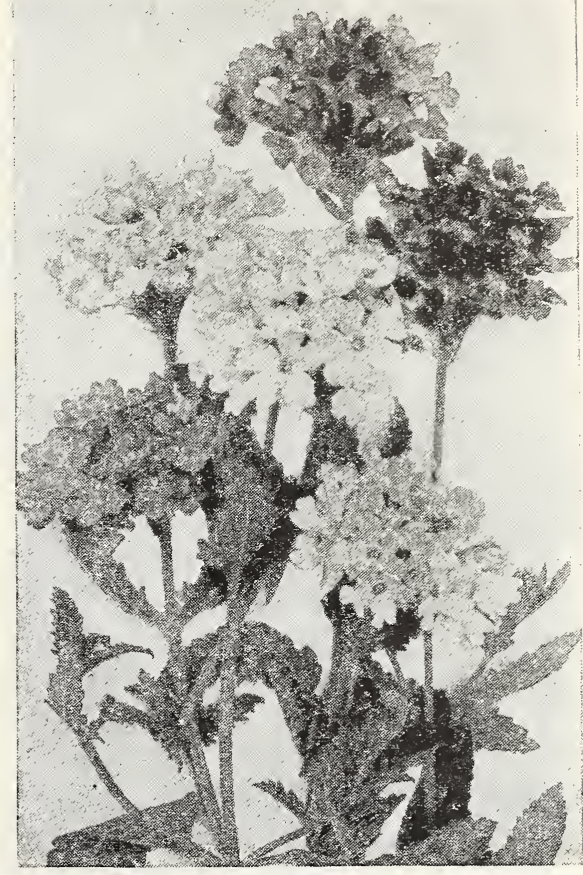

Verbena.

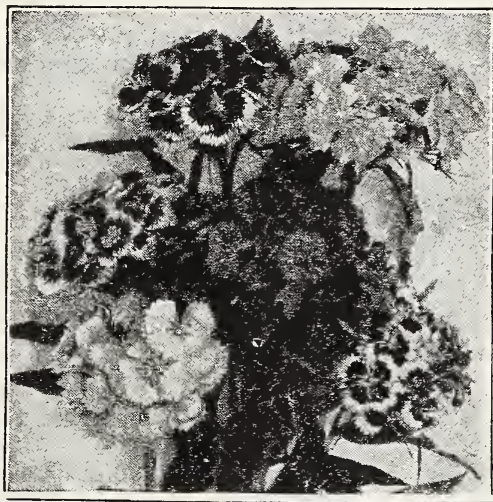

Sweet William.
1207 Statice (Sea Pink)

Our annual statice is not only a beautiful fiowretaining its true colors making it excellent for colors. Pkt, 10c; $1 / 4 \mathrm{Oz}_{\text {, }}$ $25 \mathrm{c}$; $\mathrm{oz}, 70 \mathrm{c}$

\section{Stokesia}

(Stokes' Aster or Cornflower Aster).

A lovely hardy perennial plant 18 inches high, producing an abundance of handsome flowers from July to October. Flowers rich blue, like a giant Flt, $15 \mathrm{c}$; $1 / 16 \mathrm{oz}, 40 \mathrm{c}$.

Stocks, Annual er in the border, but dries

1212 Mammoth Eary Eranching Nice. This wonderful type produces plants often 3 feet tall, each bearing 6 to 8 fully developed flower stalks. The flowers appear on the long, stiff stalks like small rosettes, are exceedingly fragrant, and range through a most complete scale of all the soft and distinct shades. While fine Stocks can be raised from seed sown outdoors, the finest plants are raised from seed sown indoors and transplanted to the garden. Pkt, 10c; 1/8 oz, 40c.

1209 Cut and Come Again. Dresden Perpetual, useful for outdoor bedding as well as for pots or cut flowers. Grows 18 inches high and throw out numerous side branches, all bearing very double, fragrant flowers. Fkt, $10 \mathrm{c} ; 1 / 16 \mathrm{cz}, 35 \mathrm{c}$.

2211 Dwarf Ten weeks. A favorite for outdoor bedding, the

1068 Sweet Rocket-Evening Scented Stock

Perennial plants growing 2 feet tall. Large panicles of white and purple fiowers from June to August. Deliciously sweet scented. Pht, 10c; oz, 65c

\section{Sweet William, Hardy Biennial}

These are excellent border plants, fine for cut flowers, an should be included in every garder. While they are biennial, it is best to sow the seed every year as the young plants bloom mor freely. The color and size of these varieties are far suprior to the old-fashioned kinds.

1270 single. The simplicity of the single bloom is often preferred 1271 Double duixed. Plot, 10c; $1 / 4$ oz, 30c; oz, $\$ 1.00$. 


\section{Sweet Peas}

Locate your planting where there will be uninterrupted sunlight, in as good soil as possikle. For the finest blooms, dig a trench about 20 inches deep, fill in this trench with alternate layers of soil and well rotted manure. Sweet Peas should be planted as early as the ground can be worked, light frost will not hurt them. Sow the seeds in a double row, about 4 inches between seeds, don't crowd them. Plant not less than 2 inches deep and draw the soil up to the plants when they are about 3 inches high. Vining support should be supplied early, preferably at time of planting. To get the best colors add a little fine charcoal to the soil. Water freely. The more you cut the flowers off the more they will bloom, keep on eutting.

We do not offer a long list of varieties nor any high priced novelties, but this list is a carefully selected list of proven merit and each variety listed is a leader in its class.

\section{Summer Flowering Spencers}

These are the Giant Waved varieties. The plants climb 4 to 5 feet high. The blossoms are large with waved petals and average four on each stem. The stems are long, and fine for cut flowers.

1243 Crimson ring. Pure deep crimson, the most pronounced pure deep red of all Sweet Peas. It is a much clearer and finer shade of deep, but bright crimson than King Edward and is greatly preferred. Plkt, 10c; oz, 20c; $1 / 41 \%, 65 \mathrm{c}$.

1222 Del Monte. A rich salmon-cerise-pink. Of perfect Spencer form, large and bold and with wavy or fluted petals. Both standard and wings are the same shade and the color is well fixed so that it does not sunburn. Under artificial light a spray or bowl of Del Monte is a delight. The vines are vigorous, the stems are long and bear almost uniformly four blossoms. Pkt, 10c; oz, 25c; $1,41 \mathrm{~b}, 85 \mathrm{c}$.

1221 Doreen. A huge bright rose-carmine, the very best of this color class. The color is particularly bright and striking. Vigorous grower, long stems, four large blossoms to the stem. Pkt, 10c; 0z, 20c; 1/4 1b, 65c.

1233 Edna IMay, Improved. A pure glistening white. Plrt, 10c; oz, 20c; $1 / 41 \mathrm{~b}, 65 \mathrm{c}$.

1238 Elfrida Pearson. Large, deep blush pink, buds and young flowers having a bronze sheen. Plet, 10c; oz, 20c; $1 / 41 \mathrm{~b}, 65 \mathrm{c}$.

1235 सtawlmark Fink. A rich bright rose-pink, deeply flushed and shaded salmon. Free flowering. vigorous grower. Pkt, 10c; oz, 20c; $1 / 41 \mathrm{~b}, 65 \mathrm{c}$.

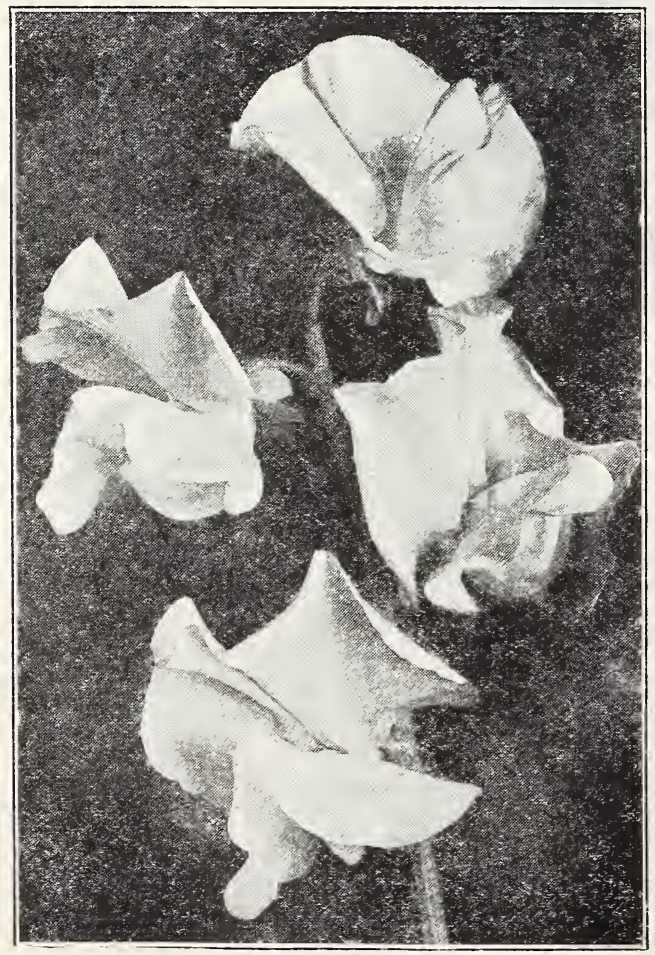

1223 Iing white. A remarkable large pure white of perfect form. The grand flowers are borne almost invariably in "fours." Pkt, 10c; 0z. 20c; $1 / 41 \mathrm{~b}, 65 \mathrm{c}$.

1224 Miary Pickford. A beautiful dainty cream pink, very lightly suftused with salmon and the effect is $r$ :ost charming whether in a bunch or single spray. Strong growth and perfect form. Award of Merit from the British National Sweet Pea Society. Pkt. 10c; 0z, 25c; $1 / 41 \mathrm{~b}, 85 \mathrm{c}$.

1242 Miss California. A distinct shade of salmon-pink and the effect is extremely beautiful whether under natural or artificial light. In the gárden Miss California is most attractive as the handsome flowers stand out from the heavy foliage which forms a most effective background. Plst, 10c; oz, 25c; 1/4 1b, 75c.

1244 Mrs. Tom Jones. A real azure-blue, exceedingly attractive. Pkt, $10 \mathrm{c} ; 0 \mathrm{z}, 20 \mathrm{c} ; 1 / 4 \mathrm{lb}, 65 \mathrm{c}$.

1225 Pinkie. A very large deep rose-pink. Four mammoth flowers are well placed on each long stem. Very vigorous grower and a continuous bloomer. This new variety should be in every garden. Plst, 15c; oz, 40c; $1 / 41 \mathrm{~b}, \$ 1.25$.

1229 Powerscourt. The finest lavender and one of the largest flowered Sweet Peas. Pkt, 10c; oz, 25c; 1/4 1b, $75 \mathrm{c}$.

1234 Rosabelle. Large, light rose. Pkt; 10c; oz, 20c; $1 / 41 \mathrm{~b}, 65 \mathrm{c}$.

1231 Royal Purple. The color is near "royal" purple and deepens and improves as the flowers age. Pkt, 10c; $0 z, 20 c ; 1 / 41 b, 65 c$.

1226 Royal Scot. A true orange-cerise-scarlet. A very strong grower producing freely four-flowered stems. Wonderful brilliancy. Pkt, 10c; oz, 25c; 1/4 1b, 75c.

1240 Tangerine, Improved. A rich glowing orange, large and beautifully waved. Pkt, $10 \mathrm{c} ; 0 \mathbf{0 z} 20 \mathrm{c} ; 1 / 41 \mathrm{~b}, 65 \mathrm{c}$.

1227 warrior. A rich deep maroon. Flowers very large and fine form. Pkt, 10c; 0z, 25c; 1/4 1b, 75c.

1228 Youth. The very best of all picotee-edged Sweet Peas, being a clear waxy white with a well defined clear pink edging. Not only beautiful in appearance, it is wonderfully fragrant having the delicate scent of orange blossoms. Pkt, 10c; 0z, 20c: 1/4 1b, 65c.

1245 Special Strain Spencer Mixture. Made from our carefully prepared formula. A perfectly balanced, finely proportioned assortment of color will be had from this mixture. Pkt, 10c: 0z, 20c; 1/4 1b. 65c; 1b. \$2.00. 


\section{Early Flowering Long Season Spencers}

Practically the same as the Summer Flowering Spencers except that they bloon 3 to 5 weeks earlier. If you cut the blossoms and don't allow them to go to seed they will often bloom until frost. In the hotter valleys where Sweet Peas are often a failure, the Early Flowering Spencers will usually be in full bloom before any hot weather comes.

1260 Farly Aviator. Dazzling crimson-scarlet. Sun-proof and

very free blooming. Plst, $15 \mathrm{c} ; 1 / 2 \mathrm{oz}, 35 \mathrm{c} ; \mathrm{oz}, 55 \mathrm{c} ; 1 / 41 \mathrm{~b}, \$ 1.65$ 1258 Early Glitters. Standard bright orange-cerise, wings deeper. A live fire variety. Pkt, 15c; $1 / 2$ oz, 35c; Oz, 55c; $1 / 4$ Ib, $\$ 1.65$.

1264 Early Grenadier. The large flowers are a rich poppy scarlet. Plt, 15c; $1 / 2$ oz, 40c; oz, 60c; $1 / 41 \mathrm{lb}, \$ 2.00$.

1262 Farly Iarmony. The best clear lavender; very large. Plt, 15c; 1/2 oz, 35c; oz, 55c; 1/4 Ib, \$1.65.

1248 Early Iiberty. Large deep crimson. Plt, 15c; $1 / 2$ oz, 35c; oz, 55c; 1/4 1b, $\$ 1.65$.

1263 Early Mrs. Kerr. An excellent salmon; always in demand as a cut flower. Pkt. 15c; $1 / 2$ oz, 40c; oz, 60c; $1 / 41 \mathrm{~b}, \$ 1.75$.

1266 Farly Orange Iing: A beautiful glowing orange, and practically sunproof. It throws "fours" regularly on the long stiff stems. A spray of this variety under artificial light is glorious. The richest and deepest orange colored Early Sweet Pea. Pkt, 25c; 1/2 0z, 60c; 0z, $\$ 1.00$.

1256 Early Snowflake. Large, pure white. Pkt, 15c; 1/2 0z, 35c; oz, 55c; $1 / 41 \mathrm{~b}, \$ 1.65$.

1268 Farly Superior Pink. A beautiful rose-pink very slightly shaded with salmon. This extremely light salmon shading gives more life to the color in the day time and under artificial light greatly adds to the color effect. Awarded a silver medal at the International Flower Show in New York, flowers exhibited at this show measured $21 / 2$ inches across. Pkt, 15c; 1/2 Oz, 40c; oz, 60c; 1/4 1b, $\$ 2.00$.

1267 Early Vulcan. A bright vivid scarlet which never burns or scalds; in fact, the brighter and hotter the sun, the brighter and more intense the color. Long stems with three or four blossoms gracefully spaced. Pkt, 15c; 1/2 oz, 35c; oz, 55c; 1/4 1b, \$1.65.

1269 Farly Zvolanek's Perfection. A bright crimson-pink with enormous well formed blossoms. Pkt, 15c; $1 / 2, \mathrm{cz}, 40 \mathrm{c} ; \mathrm{oz}, 60 \mathrm{c}$; $1 / 4$ 1b, \$2.00.

1261 Farly Zvolanek's Rose. A select strain bearing enormous rose-pink blossoms. Pkt, 15c; $1 / 2$ oz, 35c; oz, 55c; $1 / 41 \mathrm{~b} . . \$ 1.65$.

1254 Farly Flowering Spencer Mixtuxe. A beautifully palanced mixture made up from named varieties. Plt, $10 \mathrm{c}$; oz, $30 \mathrm{c} ; 1 / 4 \mathrm{Ib}, 90 \mathrm{c} ; 1 \mathrm{~b}, \$ 2.70$.

\section{Grandiflora Mixed}

While there are many beautiful flowers among the Granditiora Sweet Peas they are almost entirely replaced by the Waved Spencer varieties. Grandifloras last longer after cutting than other types. They are very free seeders and hence cheaper in price. Pkt, 5c; $0 z, 10 c ; 1 / 41 b, 30 c ; 1 b, 90 c$.

\section{Inoculate Your Sweet Peas}

Nodogen insures abundant Sweet Pea blossoms of gorgeous coloring. We have a special Garden Size for your Sweet Peas, and you can use part of it for your garden peas and beans; it will give them the nitrogen they need, too. Ask for Garden Size Nodogen, 25c, postpaid.

\section{Thunbergia}

An elegant annual climber of graceful, slender habit; climbs to a height of 5 feet. Thunbergia is particularly fine for a ground cover; the vines spread quickly along the ground, completely covering it with the rich green, glossy foliage. The colors of the flowers are strikingly beautiful; white, yellow and deep orange, mostly with a deep purplish black eye, suggesting the name of Black-Eyed Susan Vine. Pit, 10c; $1 / 8 \mathrm{oz}, 35 \mathrm{c}$.

\section{Tritoma}

\section{(Red Hot Poker Plant)}

Massive orange-scarlet flower spikes produced on plants 3 feet tall. Blooms during Summer. Needs Winter protection against frost. Plat, 15c; 1/16 oz, 65c.

\section{Violet}

Sweet Violet. The Czar. A very large flowered type of a good blue color. Pkt, 10c; 1/8 oz, 50c.

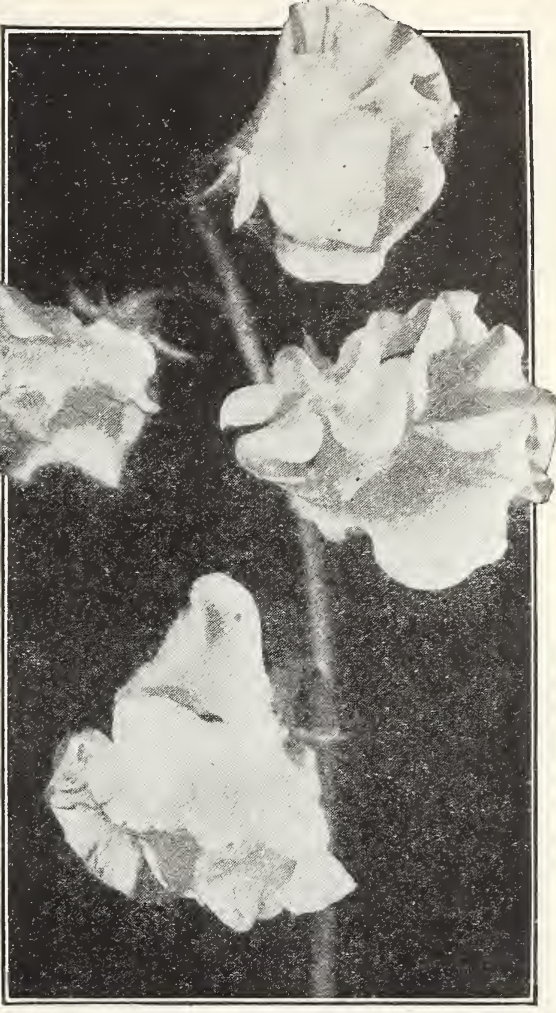

Early Superior Pink Sweet Peas.

\section{Verbena, Annual}

Verbenas thrive in almost any situation and in all good garden soils. They are one of the most popular annuals and lend themselves to many uses. For beds, borders and window boxes they are particularly fine and they are frequently used for an undergrowth to tall plants. The clusters of showy and often fragrant flowers are borne in constant succession from June until frost.

1279 Gigantea Mized. Illustrated in color on back cover. A new strain of compact plants, bearing immense trusses with individual florets measuring an inch or over in diameter. A wonderful mixture of large flowering varieties. Pkt, 15c; $1 / 8$ oz, 45c-

1280 Mammoth Iucifer. A vivid scarlet self colored flower of mammoth size. By far the most popular variety. Plit, 15c; $1 / 8$ oz, 40c.

1278 Mixed Colors. Plnt, 5c; $1 / 8$ oz, 20c; 1/4 0z, 35c; oz, $\$ 1.00$.

\section{Vinca, Periwinkle}

Ornamental free blooming plants, with dark, laurellike foliage and handsome rose, white with rose eye and pure white flowers. Seed should be sown early and then the plants will bloom the first Summer. They can be taken up in the Fall like Chrysanthemums, potted, and kept in bloom through the Winter. Plt, 10c; $1 / 8$ oz, 30c.

\section{Wallflower, Perennial}

Wallflowers thrive where the weather remains fairly cool during the Summer. They are most beautiful for beds, borders and also for cutting. The oriental coloring of the flowers in their rich reds and yellows is very effective, and the peculiar sweet fragrance of their flowers should win favor. Raised in pots they will bloom freely and can be taken into the house when Fall frosts are expected. Pkt, 5c; 1/4 oz, 20c.

\section{Wild Cucumber Vine}

The quickest growing climber on our list. If planted in the Spring soak the seed in warm water to assist germination. Pkt, 5c; oz, 20c. 


\section{Zinnia \\ (YOUTE AND OID AGE)}

Zinnias are hardy annuals and about the simplest and easiest to start and care for of all flowers. The seed is usually sown in rows in May. The plants may be transplanted at any stage of their growth, so that many people start the seed indoors and transplant them to the flower beds in order to get real early blooms.

1295 Cactus Quilled. Distinct in form from all other Zinnias. as the petals are so quilled that they become almost tubular. They are straight, radiating from the center of the flowers, which thus greatly resemble a fine-petalled Cactus Dahlia. As the back of the petals is of a distinct color, it gives the flower a bi-colored appearance. Pkt, 10c; 1/8 oz, 35c.

1293 Iilliput Mired. Plants form handsome little bushes, 12 inches high, and fairly bristle with tiny short-stemmed, very double flowers, hardly ex-
ceeding a daisy in size; bloom all Summer. Pkt, 10c; $1 / 8$ oz, $30 \mathrm{c}$.

\section{Dahlia-Flowered Zinnia}

The blooms so closely resemble dahlias that it is almost necessary to look at the foliage to make sure they are not dahlias. The Dahlia-Flowered Zinnia is the finest development in this old-fashioned flower. Originated by the late John Bodger, it was a flower of which he was justly proud.

1299 Canary Bird. Illustrated in color on inside back cover. A lovely shade of bright Primrose. The flowers are very large and hold their color well until they have passed their prime. Pkt, 20c; $1 / 8$ oz, 60c.

1300 Dream. Illustrated in color on inside back cover. A fine, deep lavender, turning to purple as they age; a new, desirable shade in Zinnias. Plat, 20c; $1 / 8$ oz, 60c.

1305 Exquisite. By far the most pleasing of our collection. Truly dahlia-flowered as regards form and size. Color light rose with center a deep rose. Pkt, 20c; $1 / 8$ oz, 60c.

1301 Golden State. Rich golden-yellow shading to bright orange as the flowers reach full size. Plit, 20c; $1 / 3$ oz, 60c.

1308 Illumination. Illustrated in color on inside back cover. A striking self color of deep rose. True
dahlia-flowered in form and size. Plit, 20c; $1 / 8$ oz, $60 \mathrm{c}$.

1302 Old Rose. A real old rose shade. Plkt, 20c; $1 / 8 \mathrm{oz}, 60 \mathrm{c}$.

1307 Oriole. The most beautiful of its class. It is an immerse orange and gold bicolor, changing slightly as it ages, but at all times worthy of the beautiful bird for which it is named. Pkt, 20c; $1 / 8$ oz, 60c.

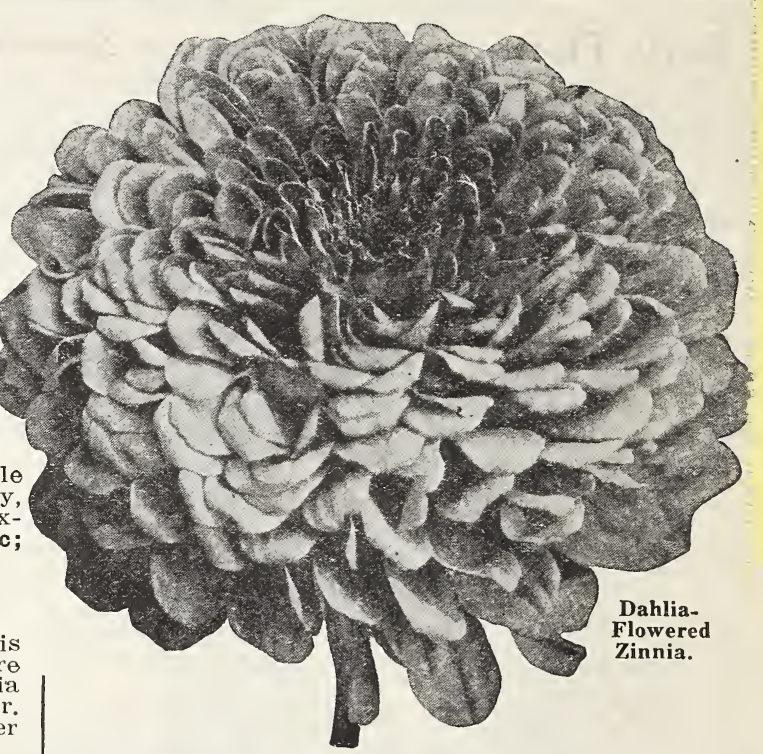

1304 Polar Bear. A very large, pure white, the best white yet seen in Zinnias. Pkt, 20c; 1/8 oz, 60c. 1298 mixed. A well balanced mixture of the above varieties. Plt, $10 \mathrm{c}$; $1 / 8 \mathrm{oz}, 25 \mathrm{c}$; oz, $\$ 1.00$; $1 \mathrm{~b}, \$ 12.50$.

\section{GIANT IMAMIMOTF ZINMIAS}

Attractive flowers but not as full as the Dahlia Flowered.

1326 Bright Rose. Plt, 10c.

1332 Burnt Orange. Pkt, 10c.

1322 Canaxy Yellow. Pkt, 10c.

1330 Deep Salmon Rose. Pkt, 10c.

1328 Orange. Pkt, 10c.

1324 Purple. Pkt, 10c.

1335 White. Pkt, 10c.

1320 Mixed. Plst, 5c; oz, 50c.

\section{Cut Flower Mixture}

This is a complete mixture of easily grown annuals, which liave proven to do well and bloom freely under widely different conditions of soil and weather. It is sure to give a fine display with a minimum of care. If sown thinly either in rows or broadcast, the seeds will make a fine solid bed which yields flowers from early Spring until Fall. Pkt, 5c; 0z, 20c; 1/4 1b, 45c.

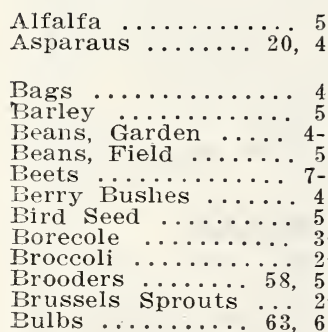

Calf Meal

Cabbage ...2, $10,11,48$

Caladiums .........6. 64

Cannas ..............6. 63

Carrots ......... 12,25

Cauliflower ....... 15, 48

Celeriac ........... 20

Celery ...........

Ceresan $\ldots \ldots \ldots \ldots \ldots, 56$

Chufas $\ldots \ldots \ldots \ldots \ldots \ldots .20$

Cinnamon Vine ......6. 64

Citron ........... 20

Clovers $\ldots \ldots \ldots \ldots 50,51$

Collections $\ldots 4,3 \dot{3}, 66$

Corn, Field ........ 55

Corn, Sweet $\ldots .2,16,17$

\section{N D E X}

\begin{tabular}{l|l} 
Corn Salad $\ldots \ldots \ldots \ldots$ & 20 \\
Cow Insecticides ... 27, 41, 65
\end{tabular}

Cress ........... 5929 Kaffir Corn ........ 55

Cucumbers $\ldots \ldots \ldots$ is, $19 \quad \begin{aligned} & \text { Kalfe } \\ & \text { Kale } \ldots \ldots \ldots \ldots \ldots\end{aligned}$

Cultivators $\ldots \ldots \ldots \ldots, 13$

Dahlias ...........6. 64

Dandelion $\ldots \ldots \ldots \ldots, 20$

Dill $\ldots \ldots \ldots \ldots \cdots, 21$

Dust Guns $\ldots \ldots \ldots \ldots .47$

Egg Plant ....21, 48

Endive $\ldots \ldots \ldots \ldots, 21$

Fertilizers $\ldots . .15,32,44$

Flower Seeds, Cover

Pages, ........62-80

Flower Plants ....6.64 64

Garlic $\ldots \ldots \ldots \ldots$

Gladioli $\ldots \ldots \ldots \ldots \ldots \ldots 63$

Grains . . . . .

Grasses $\ldots \ldots \ldots \ldots$ 50-54

Gumbo $\ldots \ldots \ldots \ldots, 31$

Herbs $\ldots \ldots \ldots \ldots .21$

Horseradish $\ldots \ldots \ldots$. 48

Hotkaps ............ 21

Implements $\ldots \ldots \ldots \ldots$.

Inoculating Bacteria. 51
Kohl-rabi $\ldots \ldots \ldots \ldots \ldots 30$

Lawn Grass ........ 53

Leek ..............

Lettuce $\ldots \ldots \ldots 2,22,23$

Mangels ......... 7

Millets ............ 54

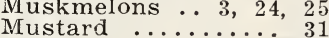

Oats ..................... 56

Okra.$\ldots \ldots \ldots \ldots \ldots{ }_{31}$

Onions $\ldots \ldots \ldots \ldots \ldots 28-30$

Onion Plants ........ 30

Onion Sets ........ 30

Parsley .......... 37

Parsnips ........... 37

Peanuts $\ldots \ldots \ldots \ldots \ldots 446$

Peas, Garden... 3, 32-35

Peas, Field ....... 57

Pie Plant $\cdots \cdots 3,46,48$

Plants ..... $30,47,48$

Pop Corn .......... 17

Potatoes …......... 57

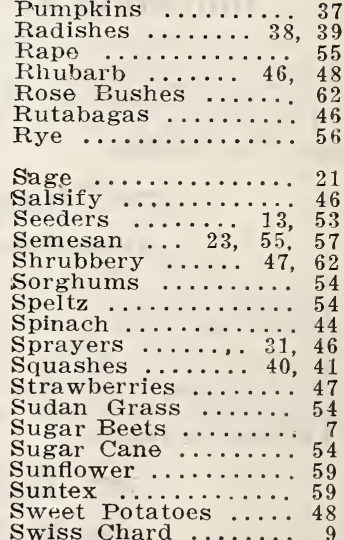

Tomatoes . . $42,43,48$ Turnips ....... 45, 46

Vegetable Plants.. 30, 48

Watermelons .. 3, 26, 2 r

Wheat ...........

Wonderberry ........ 


\section{FREE Mile High FREE Dahlia-Flowered Zinnias}

The Latest Development in Zinnias, Bearing Perfect Flowers of Mammoth Size

$20 \%$ extra value on early order.

These "Mile Higlı" Dahlia Flowered Zinnias as illustrated and several other beautiful colors are given FREE with early orders.

The Dahlia Flowered Zinnias are a wonderful improvement over the older varieties, so much of an improvement that they do not seem to be the same flower. The large size, fullness of the petals, extraordinary color range, and good keeping qualities of this flower have all contributed to its popularity.

The Dahlia Flowered Zinnia keeps wonderfully well as a cut flower. It is so far immune to all diseases. It is easily grown and seems to be adapted to all climates, as we have received letters from customers in all sections of the country, remarking on the wonderful display made by these flowers.

The varieties illustrated are Canary Bird, Dream and Illumination.

1299. Canary Bird. A delicate shade of primrose, very large and holds its color well until out of bloom.

1300. Dream. A fine, deep lavender, turning to purple, a new desirable shade in Zinnias. 1308. Illumination. True Dahlia Flowered in form and size. A striking self color of deep rose.

Or you may choose your FREE seeds from the following varieties:

1305. Exquisite. A beautiful variety, similar to Illumination. Color light rose, with a deep rose center.

1301. Golden State. A very rich orangeyellow. Yellow in the bud, turning to an attractive orange when in full bloom.

1302. Old Rose. A real old rose shade.

130\%. Oriole. The most beautiful of its class. It is an immense orange and gold bicolor, changing slightly as it ages, but at all times worthy of the beautiful bird for which it is named.

1304. Polar Bear. A very large pure white, the best white yet seen in Zinnias. True Dahlia form.

1298. Mixed. A well-balanced mixture of the above varieties.

All varieties of the Dahlia Flowered Zinnias are priced 20c per packet; 600 for $1 / 8$ oz.

\section{Special Free Offer}

Witl every dollar's worth of seed ordered from this catalog before February first we will include one 20c packet (your choice of colors) of the beautiful Dahlia Flowered Zinnias.

With every two dollars' worth of seed ordered from this catalog during February we will include one 20c packet of Dahlia Fowered Zinnias, (your choice of colors).

On large orders we will supply FREE Zinnia Seeds in bulk, giving you more seed rather than a number of packets. Check your choice of varieties on the back of the orcier blank. 


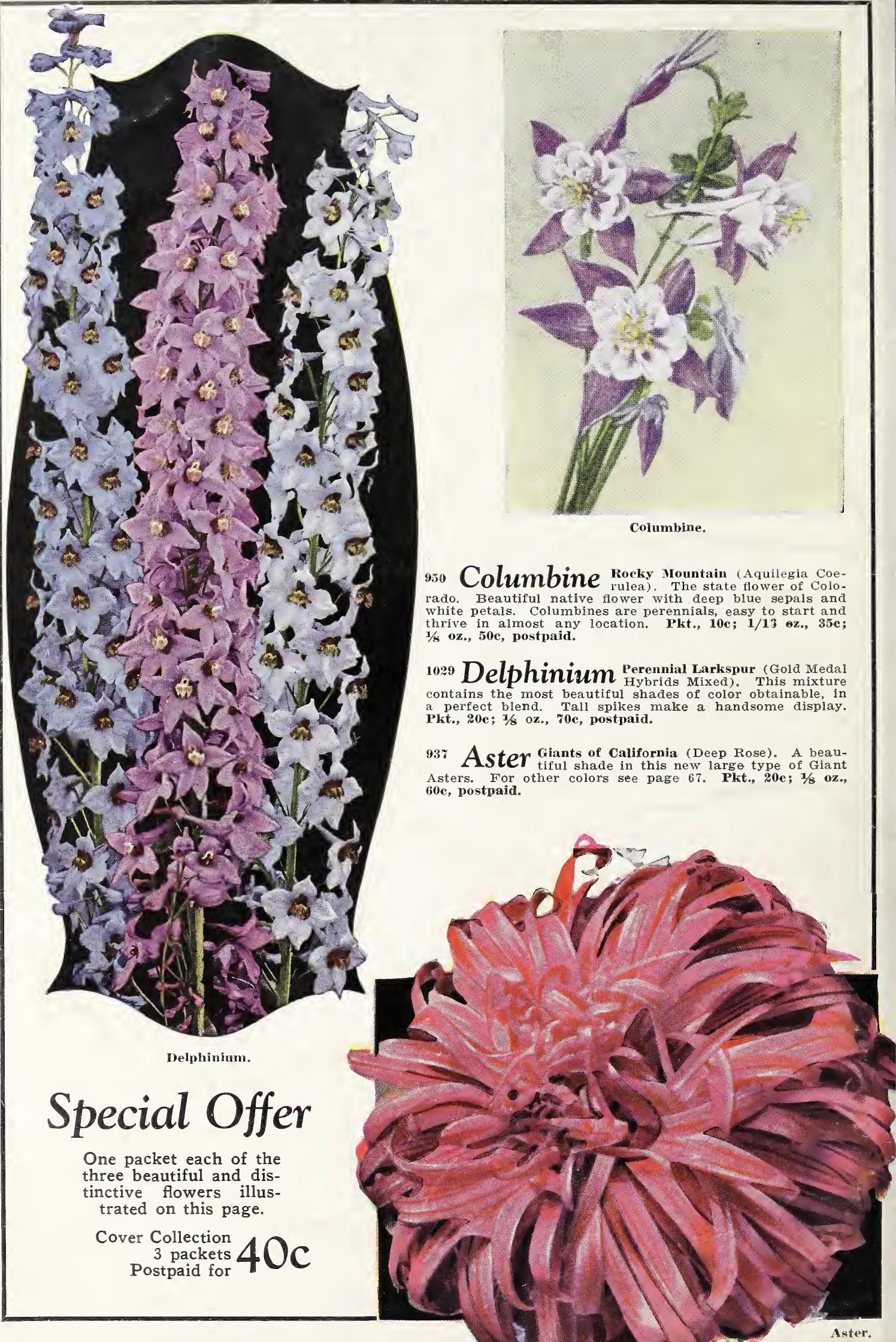

